UNIVERSIDADE DE SÃO PAULO

FACULDADE DE FILOSOFIA, LETRAS E CIÊNCIAS HUMANAS

DEPARTAMENTO DE SOCIOLOGIA PROGRAMA DE PÓS-GRADUAÇÃO EM SOCIOLOGIA

\title{
ESTADO, SOCIEDADE E DESCENTRALIZAÇÃO DA POLÍTICA PÚBLICA DE SAÚDE NO MÉXICO (1982-2000) E NO BRASIL (1985-1998): CONSTRUINDO UM NOVO DOMÍNIO PÚBLICO EM CONTEXTOS DE DUPLA TRANSIÇÃO POLÍTICA \\ (versão com correções)
}

Fabiana da Cunha Saddi

Tese apresentada ao Programa de PósGraduação em Sociologia, do Departamento de Sociologia da Faculdade de Filosofia, Letras e Ciências Humanas da Universidade de São Paulo, para obtenção do título de Doutor em Sociologia.

Orientador: Prof. Dr. Brasilio Sallum Júnior

São Paulo

2004 
UNIVERSIDADE DE SÃO PAULO

FACULDADE DE FILOSOFIA, LETRAS E CIÊNCIAS HUMANAS

DEPARTAMENTO DE SOCIOLOGIA

PROGRAMA DE PÓS-GRADUAÇÃO EM SOCIOLOGIA

\section{ESTADO, SOCIEDADE E DESCENTRALIZAÇÃO DA POLÍTICA PÚBLICA DE SAÚDE NO MÉXICO (1982-2000) E NO BRASIL (1985-1998): CONSTRUINDO UM NOVO DOMÍNIO PÚBLICO EM CONTEXTOS DE DUPLA TRANSIÇÃO POLÍTICA}


"Poderemos ensaiar a organização de nossa desordem segundo esquemas sábios e de virtude provada, mas há de restar um mundo de essências mais íntimas que, esse, permanecerá sempre intacto, irredutível e desdenhoso das invenções humanas. Querer ignorar esse mundo será renunciar ao nosso próprio ritmo espontâneo, à lei do fluxo e refluxo, por um compasso mecânico e uma harmonia falsa. Já temos visto que o Estado, criatura espiritual, opõe-se à ordem natural e a transcende. (...) As formas superiores da sociedade devem ser como um contorno congênito a ela e dela inseparável: emergem continuamente das suas necessidades específicas e jamais das escolhas caprichosas".

(Sérgio Buarque de Holanda, Raízes do Brasil)

"A exaltação e a glorificação de México-Tenochtitlán transforma o Museu de Antropologia num templo. O culto que se propaga entre seus muros é o mesmo que inspira os livros escolares da história nacional e os discursos dos nossos dirigentes: a pirâmide em degraus e a plataforma do sacrifício. (...) Se a política é uma dimensão da história, a crítica da história é também crítica política e moral. Ao México do Zócalo, de Tlatelolco e do Museu de Antropologia temos de opor não outra imagem: todas imagens padecem de tendência fatal à petrificação, mas sim a crítica: o ácido que dissolve as imagens. (...) A crítica é a aprendizagem da imaginação na sua segunda volta, a imaginação curada da fantasia e decidida a enfrentar a realidade do mundo".

(Octavio Paz, O Labirinto da Solidão e Post Scriptum) 


\section{Dedicatória}

Para meus pais, Farhat e Vânia, minha avó Elzamira, e minhas irmãs, Luciana, Adriana, Tatiana e Cristiana: expressões do amor de Deus por mim. 


\section{Agradecimentos:}

Ao Conselho Nacional de Desenvolvimento Científico e Tecnológico (CNPq), pela bolsa de doutoramento e apoio à viagem de campo ao México, junto com o Consejo Nacional de Ciencia e Tecnología (CONACyT).

A Pró-Reitoria de Pós-graduação e Pesquisa da Universidade de São Paulo, pelo auxílio para apresentação de trabalho no Congresso da Sociedade de Estudos Latino-Americanos (SLAS).

A Brasilio Sallum Junior, meu orientador, incentivador e responsável direto pela minha inserção no estudo comparativo, cujos ensinamentos e sugestões foram essenciais para o desenvolvimento deste trabalho final.

A Carlos Alba, do Centro de Estudos Internacionais do Colégio do México, pelo auxílio concedido a pesquisa de campo no México.

A Amélia Cohn e Ana Luiza D’Ávila Viana da FM/USP, pelos comentários efetuados na ocasião do Exame de Qualificação.

A Guillermo Soberón Acevedo e Gustavo Nigenda da FUNSALUD, a Oliva López-Arellano e Gustavo Leal da UAM Xochimilco, a Asa Cristina Laurell da Secretaria de Saúde do DF, aos pesquisadores Enrique Cabrero, Raquel Abrantes, Sofia Arjonilla, Odilia Ulloa, Juan Molina, aos assessores Lucila Olvera, Alberto Maldonado, e a Ricardo Perez e Luis Duran do IMSS, pelas entrevistas realizadas, todas essenciais para a compreensão da reforma mexicana. A Deputada Beatriz Paredez Rangel, pela entrevista realizada com a intermediação da Embaixada do Brasil no México. A Victor Soria, pela bibliografia e atenção concedida em 2001 no México.

A Emerson Elias Merhy, Paulo Eduardo M Elias, Carmem Lavras, José Carlos da Silva, Gilson Carvalho, Sarah Escorel, Roseni Pinheiro, Luiza Heimann, Carlos Mosconi, Áquilas Mendes e Rosana Onoko, pelas entrevistas, conversas, indicações bibliográficas, envio de textos, apoio e aprendizado sobre a mobilização social e política na Saúde no Brasil. A Nelson Rodrigues dos Santos, pelo envio do texto preparativo para a XII Conferência Nacional de Saúde.

A Marcos Moraes pelo contato com pessoas que trabalharam com seu pai, na Secretaria Municipal de Campinas.

A Basilia Aguirre e Leda Paulani pelo incentivo a minha pesquisa de doutoramento nestes anos de Fipe. A Ronaldo Teixeira e Jorge Alejandro pela transcrição de parte das entrevistas e sobretudo a Ronaldo pela ajuda na normatização da bibliografia.

A Letícia Calderón e Raquel Abrantes: hoje amigas, mas que um dia me acolherem na condição de estranha no México. A Raquel, pelas indicações, sugestões bibliográficas e conversas sobre as reformas. Aos amigos Adrian Gurza Lavalle, Vidal Llerenas e Ricardo Garroux que, de distintas formas e em diferentes lugares, deram grande contribuição nesta caminhada.

Ao Centro de Estudos Latino-Americanos da Universidade de Cambridge e, em particular a Julie Coimbra, pelo apoio na ocasião da pesquisa realizada na University Library. A Danilo Igliori e Julie Coimbra, pela amizade durante a minha estadia em Cambridge. 


\section{Resumo}

Esta pesquisa analisa o processo recente de reforma da política pública de saúde para a população não-assegurada, no México (1982-2000) e no Brasil (1985-1998), como um processo de legitimação política, em construção nas esferas políticas macro (nacional) e micro (estadual no México e municipal no Brasil), e em articulação com as esferas da sociedade civil e econômica. Enfocaremos as estratégias de descentralização, construídas em distintos contextos de dupla transição a fim de integrar a população não-assegurada na política. O problema da legitimação da nova política pública - legalizada e reivindicada como legítima pela autoridade macro, porém dificilmente reconhecida durante a decisão e implementação nas esferas políticas micro -, será relacionado à problemática da identidade, isto é: ao fato do “novo” ser construído não apenas por novos atores e instituições, mas também por atores e instituições ainda identificados com a “velha” concepção de público que se pretende substituir/reformar. Estabeleceremos conexões entre os processos políticos macro e micro, verificando as formas distintas como as legalidades reivindicadas pelo poder macro nacional, em cada fase da reforma e país, foram realizadas no nível micro sub-nacional. A análise demonstra que um padrão mais amplo de participação direta na decisão macro, como é o caso do Brasil, resulta em níveis mais altos de identificação (política, administrativa e social) na política micro. Níveis de identificação serão posicionados no contínuo obediência-rejeição e interpretados como coeficientes de legitimidade da política pública de saúde em construção em nos dois países. 


\begin{abstract}
This research studies the recent processes of public health care reform directed at the uninsured population in Mexico (1982-2000) and Brazil (1985-1998). Reforms will be studied as a new process of political legitimacy, which is under construction at the macro (federal Government) and micro (state level in Mexico, and mainly the municipality level in Brazil) political spheres, implying different forms of articulation with the social and economic spheres. I will focus on the strategy of decentralisation, adopted in different sequences of double political transitions in order to integrate the non-insured part of the population in politics. The problem of political legitimacy will be understood as a matter of identification (values and interests); as reforms are not only constructed by "new” actors and institutions, but also by actors and institutions still identified with the "old” concept of the public. I will stress the relationships existent between the macro and micro processes, verifying if and in which terms the legalities constructed at the macro level, in each phase of the reform and country, were realized in the policy process in the micro political spheres. The analysis shows that a broader pattern of direct participation in policy-making decision, as happened in Brazil, generates higher levels of (political, administrative and social) identification. Levels of identification will be linked to positions in the obedience-rejection continuum and, thus, understood as coefficients of legitimacy in the process of constructing a new public policy in both countries.
\end{abstract}

\title{
PALAVRAS-CHAVE
}

Estado, reforma de saúde, descentralização, Brasil, México

\section{KEY WORDS}

State, health reform, decentralization, Brazil, Mexico 


\section{Sumário}

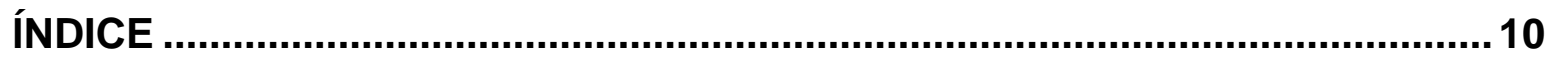

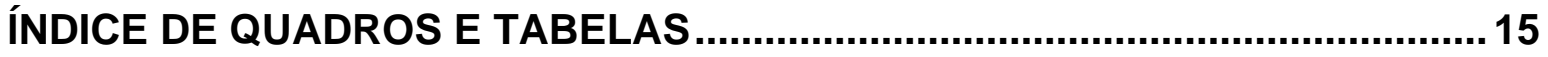

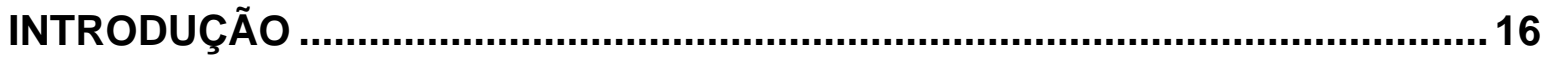

PARTE I - A POLÍTICA PÚBLICA DE SAÚDE COMO CONSTRUÇÃO POLÍTICA E SOCIAL: COMPARANDO MÉXICO E BRASIL................................................. 22

CAPÍTULO 1 - ESTADO, AUTORITARISMO E POLÍTICA PÚBLICA DE SAÚDE NA PERIFERIA DO CAPITALISMO: MÉXICO E BRASIL 23

CAPÍTULO 2 - CRISES ESTADO-CÊNTRICAS E PARTICIPAÇÃO POLÍTICA NA REDEFINIÇÃO DA POLÍTICA PÚBLICA: O PROCESSO INICIAL DA REFORMA DA POLÍTICA PÚBLICA DE SAÚDE NO MÉXICO (1970-1983) E NO BRASIL (197485).

CAPÍTULO 3 - IDENTIFICAÇÃO E LEGITIMAÇÃO NA CONSTRUÇÃO DA REFORMA PÚBLICA DE SAÚDE: LITERATURA DE REFORMA DE SAÚDE E METODOLOGIA DA ANÁLISE.

PARTE II - DECISÃO POLÍTICA E IDENTIFICAÇÃO NA REFORMA PÚBLICA DA SAÚDE NO MÉXICO: O CASO DA DESCENTRALIZAÇÃO DA POLÍTICA PÚBLICA DE SAÚDE (1982-2000)

INTRODUÇÃO 111

CAPÍTULO 4 - REFORMA DA POLÍTICA PÚBLICA DE SAÚDE E CRISE DE GOVERNABILIDADE POLÍTICA: A PRIMEIRA ETAPA DA DESCENTRALIZAÇÃO DA POLÍTICA PÚBLICA DE SAÚDE NO GOVERNO DE DE LA MADRID (1982 A 1988) 116

CAPÍTULO 5 - ROMPENDO COM A DESCENTRALIZAÇÃO DA POLÍTICA PÚBLICA DE SAÚDE: A REGIONALIZAÇÃO SOLIDÁRIA E PATRIMONIALISTA DO GOVERNO DE CARLOS SALINAS (1988 A 1994) 132 
CAPÍTULO 6 - CRISE POLÍTICA, ESTABILIZAÇÃO ECONÔMICA E RETOMADA DA DESCENTRALIZAÇÃO DA POLÍTICA PÚBLICA DE SAÚDE NO GOVERNO DE ZEDILLO (1994 A 2000) 143

PARTE III - DECISÃO POLÍTICA E IDENTIDADE NA CONSTRUÇÃO DA POLÍTICA PÚBLICA DE SAÚDE: O PROCESSO DE LEGITIMAÇÃO DO SISTEMA ÚNICO DE SAÚDE NO BRASIL (1985-1998) ......................................................... 164

INTRODUÇÃO

CAPÍTULO 7 - A CONSTRUÇÃO DA REFORMA PÚBLICA DE SAÚDE NO PRINCÍPIO DA REDEMOCRATIZAÇÃO: O PERÍODO DO GOVERNO SARNEY (DE 1985 A 1990) 168

CAPÍTULO 8 - A CONSTRUÇÃO POLÍTICA DO SUS NO PRINCÍPIO DA REESTRUTURAÇÃO NEOLIBERAL: O PERÍODO DO GOVERNO COLLOR . 195

CAPITULO 9 - CONSTRUINDO O SUS EM TEMPOS DE INCERTEZA POLÍTICA E DE INSTABILIDADE ECONÔMICA: O GOVERNO DE ITAMAR FRANCO (DE 02/10/1992 A 01/01/1995). 207

CAPÍTULO 10 - CONSTRUINDO O SUS EM TEMPOS DE DEMOCRACIA E DE ESTABILIDADE ECONÔMICA: O PRIMEIRO GOVERNO DE FERNANDO HENRIQUE CARDOSO (DE 1995 A 1998) 222

CONCLUSÃO - LEGITIMIDADE E COMPROMETIMENTO POLÍTICO NA CONSTRUÇÃO DA REFORMA PÚBLICA DE SAÚDE NO MÉXICO E BRASIL: O CASO DA ESTRATÉGIA DE DESCENTRALIZAÇÃO PARA A POPULAÇÃO ABERTA 242

REFERÊNCIAS: ENTREVISTAS E BIBLIOGRAFIA 253 


\section{Índice}

INTRODUÇÃO

\section{PARTE I - A POLÍTICA PÚBLICA DE SAÚDE COMO CONSTRUÇÃO POLÍTICA E SOCIAL: COMPARANDO MÉXICO E BRASIL.................................................22}

\section{CAPítulo 1 - Estado, AUTORITARISMo E POLÍtiCA PÚBlica de SAÚDE NA PERIFERIA do CAPITALISMO: MÉXICO E BRASIL

1. Saúde Pública e Medicina curativa na democratização do acesso à saúde nos países desenvolvidos

1.1. Saúde Pública e o princípio da construção da cidadania nas velhas democracias: a primeira longa etapa das reformas públicas de saúde.

1.2. Reforma de saúde e consolidação da democracia social no século XX: Estado versus mercado nos Estados Unidos e Inglaterra

2. Estado e medicina curativa na periferia do capitalismo: México e Brasil 29

3. Autoritarismo pós-revolucionário e política de saúde para a população aberta no México

3.1. A construção de um sistema público-estatal dual de saúde no México.

4. Autoritarismo militar e política pública de saúde para a população aberta do Brasil42

4.1. A construção de um sistema público-estatal dual de saúde no Brasil ....

5. Conclusão .45

CAPÍTUlO 2 - CRISES ESTADO-CÊNTRICAS E PARTICIPAÇÃo POLÍTICA NA REDEFINIÇÃo DA POLÍTICA PÚBLICA: O PROCESSO INICIAL DA REFORMA DA POLÍTICA PÚBLICA DE SAÚDE NO MÉXICO (1970-1983) E NO BRASIL (1974-85).

1. Crises políticas, autoritarismo pós-revolucionário e solidariedade na saúde: nãoparticipação direta e baixa viabilidade política, México (1970-1982).

1.1. Os anos de Echeverría (1970 a 1976) - a origem política autoritário-conservadora dos programas solidários.

1.2. Os anos de Portillo (1976 a 1982): não-participação direta e inserção do conservadorismo político-econômico neoliberal na política ....

1.2.1. A gênese da inserção do conservadorismo neoliberal na política de saúde nãoassegurada no México: novo grupo e velhos espaços. ...........................................66

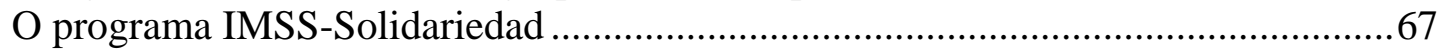

Consultoria junto aos futuros especialistas em economia da saúde

2. Crise Estado-cêntrica no Brasil, programas comunitários e luta política pela democratização na saúde. 72

2.1. Os anos do governo Geisel - a consolidação do movimento sanitário e as políticas de saúde do governo

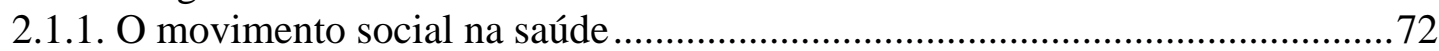

2.1.2. Os projetos de saúde do governo na gênese da liberalização política .................75 
2.2. Os anos de Figueiredo - anos de negociação política 79

3. Conclusão: legitimações distintas do público no processo inicial das reformas de saúde.

CAPÍTULO 3 - IDENTIFICAÇÃo E LEGITIMAÇÃo NA CONSTRUÇÃO DA REFORMA PÚBLICA DE SAÚDE: LITERATURA DE REFORMA DE SAÚDE E METODOLOGIA DA ANÁLISE

1. A política e o estado da literatura sobre reformas públicas de saúde nos anos 90: a política como um problema de eficiência, de relacionamento ou de statecraft?

1.1. Equipe de mudança e viabilidade política: a decisão como um problema do

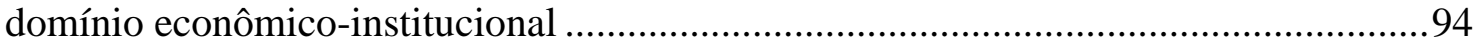

1.2. Responsabilização (accountability) como relacionamento e contexto.....................95

1.3. Governabilidade como um problema de statecraft.

2. Métodos e conceitos da análise: notas teóricas e práticas sobre os vínculos entre processos políticos macro e micro.

2.1. A decisão na esfera política macro: reivindicando a mudança no domínio público-

estatal em tempos e seqüências distintas de transição político-econômica .

2.2. O processo da política pública na esfera micro: identificação com a decisão da política macro?

3. Identificação e legitimidade na reforma do domínio público-estatal de saúde: na perspectiva micro-macro

\section{PARTE II - DECISÃO POLÍTICA E IDENTIFICAÇÃO NA REFORMA PÚBLICA DA SAÚDE NO MÉXICO: O CASO DA DESCENTRALIZAÇÃO DA POLÍTICA PÚBLICA DE SAÚDE (1982-2000) 111}

INTRODUÇÃO

1. Questões e hipóteses: o padrão restrito de participação na decisão (PDD) e a estratégia de descentralização da política pública de saúde no México......

1.1. Sobre a decisão política de reformar o domínio público-estatal na Saúde

1.2. Sobre a identificação no processo político micro (decisão e implementação)

CAPÍtulo 4 - REFORMA dA POLÍTICA PÚBLICA DE SAÚDE E CRISE DE GOVERNABILIDADE POLÍTICA: A PRIMEIRA ETAPA DA DESCENTRALIZAÇÃO DA POLÍTICA PÚBLICA DE SAÚDE NO GOVERNO DE DE LA MADRID (1982 A 1988)

1. A decisão não-participativa pela redefinição no domínio público-estatal na saúde:

autoritarismo e neoconservadorismo

1.1. Decisão autoritária e mudança no sub-setor público-estatal da SSA 121

1.2. A inserção legal de valores de mercado no público mexicano.

2. O processo de "descentralização" em 14 estados 124

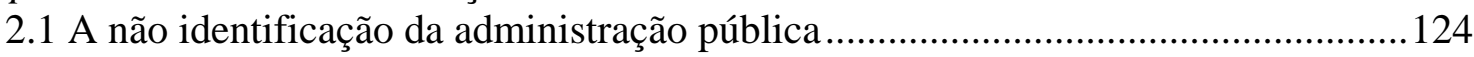

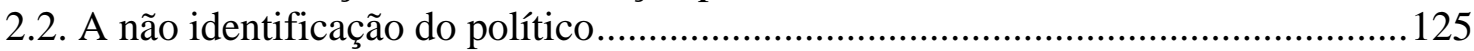

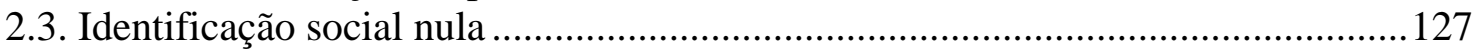

2.4. Interrompendo a construção de domínio público não reconhecido

3. Sucessão presidencial em tempo de crise 
CAPÍTUlO 5 - ROMPENDO COM A DESCENTRALIZAÇÃo DA POLÍTICA PÚBLICA DE SAÚDE: A REGIONALIZAÇÃo SOLIDÁRIA E PATRIMONIALISTA DO GOVERNO DE CARLOS SALINAS (1988

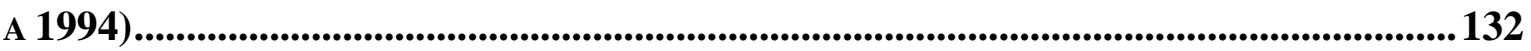

1. Decidindo por Solidariedad Social: ruptura e nova redefinição do público .133

1.2. Solidariedad Social: a valorização do populismo e do patrimonialismo na política

1.1. Rompendo com a estratégia de descentralização: reivindicando uma nova legitimidade do público

2. Implementando uma regionalização político-patrimonialista 136

2.1. Evitando conflitos, mantendo a dualidade na assistência solidária do público .....137

2.2. Identificação social e participação limitada: ausência de controle e publicidade negativa.

2.3. Identificação política: personalismo e corrupção

3. O retorno aprofundado da crise sócio-política e a sucessão presidencial 141

CAPÍTUlO 6 - CRISE POLÍTICA, ESTABILIZAÇÃo ECONÔMICA E RETOMADA DA DESCENTRALIZAÇÃo DA POLÍTICA PÚBLICA DE SAÚDE NO GOVERNO DE ZEDILLO (1994 A 2000)

1. Crise impar em tempo de neoconservadorismo: o peso político do determinismo econômico na nova redefinição do público .

1.1. Decidindo pela descentralização na saúde: autoritarismo priista e pressão global147

1.2. Evitando conflitos com os governadores e o IMSS: algum aprendizado

2. Implementando um novo domínio público sem participação social.

2.1. Identificação política e as contradições do federalismo mexicano: eficiência e autonomia política?

2.2. Identificação administrativa e os dilemas da integração: qual modelo médico público?

2.3. Identificação social e participação: prestação de contas e transparência?.

3. Uma nova aliança com a sociedade: autoritaritarismo priista e neoconservadorismo global.

4. Considerações sobre a dinâmica sócio-política da reforma pública: vínculos entre os processos políticos macro e micro. 159

\section{PARTE III - DECISÃO POLÍTICA E IDENTIDADE NA CONSTRUÇÃO DA POLÍTICA PÚBLICA DE SAÚDE: O PROCESSO DE LEGITIMAÇÃO DO SISTEMA ÚNICO DE SAÚDE NO BRASIL (1985-1998) ............................................. 164}

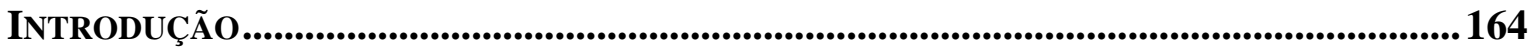

1. Questões e hipóteses: a construção da política pública de saúde no Brasil..............165 1.1. Sobre a participação no processo decisório macro .................................................165

1.2. Sobre a identificação no processo político micro .................................................167

CAPítulo 7 - A CONSTRUÇÃo DA REFORMA PÚBlica de SAÚde No PRINCíPIO DA REDEMOCRATIZAÇÃO: O PERÍODO DO GOVERNO SARNEY (DE 1985 A 1990)....................168

1. Processo decisório participativo na redefinição da política pública de saúde ..........170 1.1. A VIII Conferência Nacional de Saúde como fórum participativo.... 
1.1. Reações políticas à VIII Conferência: o cálculo da elite política e a oposição do setor privado

1.2. O processo decisório macro do SUDS

2. Identificação com a política macro no processo do SUDS? 179

2.1. O nível de identificação do político: baixa identificação estadual com identificação

municipal

2.2. Constrangimentos administrativos: a permanência do modelo INAMPsiano

2.3. Participação social e percepção do público? 186

3. A construção política do Sistema Único de Saúde na Assembléia Nacional Constituinte: representantes do setor privado e do movimento sanitarista. 189

4. A crise econômica e seus efeitos na construção do SUS 193

\section{CAPÍtulO 8 - A CONSTRUÇÃo POLÍtiCA do SUS NO PRINCÍPIO DA REESTRUTURAÇÃo NEOLIBERAL: O PERÍODO DO GOVERNO COLLOR

1. Processo decisório em tempos de liberalismo econômico e crise de governabilidade196

1.1. A construção política da Legislação Complementar: Executivo versus Congresso e movimento municipalista

1.2. O princípio da fase de regulamentação do SUS ...................................................199

1.2.1 A NOB-91: controlando a transferência de recursos do novo SUS .................199

1.3. Conferência Nacional de Saúde em tempos de crise de governabilidade .............201

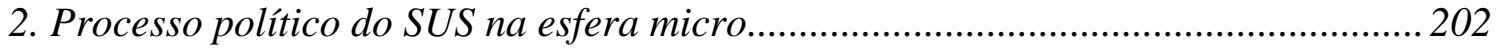

2.1. Identificação do político .....................................................................................202

2.2. Identificação da administração pública: qualidade precária e princípio da mudança no modelo médico 204

2.3. Identificação social

205

3. Paradoxos de uma política em construção: legitimidade e política de saúde nos governos de Collor e de Salinas 206

CAPITUlO 9 - CONSTRUindo O SUS EM TEMPOS DE INCERTEzA POLÍTICA E DE INSTABILIDADE ECONÔMICA: O GOVERNO DE ITAMAR FRANCO (DE 02/10/1992 A 01/01/1995)

1. O processo decisório em tempos de crise de governabilidade 208

1.1. A NOB-93 e a participação dos municipalistas.....................................................209

1.2. Crise de governabilidade e corrupção: a extinção do INAMPS ............................210

1.3. Instabilidade econômica e crise de financiamento na Saúde................................214

1.4. O processo decisório no principio da estabilização econômica: o bloqueio da NOB94

2. O processo político micro e o SUS: identificação com a política pública em tempo de crise de governabilidade.

2.1. Identificação do político: incremento da habilitação ao SUS

2.2. Identificação administrativa: herança hospitalar com crescimento dos programas de atenção básica

2.3. Identificação social: precária participação, e percepção difusa da sociedade sobre o

SUS

3. A construção da legitimidade do SUS no governo Itamar 221 
CAPítulo 10 - Construindo o SUS EM TEMPOS DE DEMOCRACIA E DE ESTABILIDAdE ECONÔMICA: O PRIMEIRO GOVERNO DE FERNANDO HENRIQUE CARDOSO (DE 1995 A 1998)

1. Processo decisório em tempos de estabilização econômica: política econômica versus política de saúde

1.1. O processo decisório na gestão de Adib Jatene: a predominância dos interesses democráticos da Saúde

1.2. O processo decisório nas gestões de Albuquerque e de José Serra: a predominância

política da Economia.

2. Implementando do SUS em tempo de estabilização econômica 231

2.1. Crise de financiamento com Identificação política

2.2. Identificação na gestão da atenção à saúde? velhas e novas práticas de assistência médica.

2.3. Identificação social: participação social limitada pela política local, opinião pública

em fase inicial de mudança....

3. Legitimidade e construção do SUS: nos anos de Zedillo e Cardoso ( $1^{\circ}$ governo).... 237

Política e Saúde no segundo governo de Cardoso: notas comparativas sobre o processo

de legitimação da Saúde

4. Considerações sobre a dinâmica sócio-política da reforma brasileira: a perspectiva micro-macro.

CONCLUSÃO - LEGITIMIDADE E COMPROMETIMENTO POLÍTICO NA CONSTRUÇÃO DA REFORMA PÚBLICA DE SAÚDE NO MÉXICO E BRASIL: O CASO DA ESTRATÉgIA DE DESCENTRALIZAÇÃO PARA A POPULAÇÃO ABERTA

1. Participação direta e identificação na construção de um novo domínio público na saúde

242

2. Legitimidade e comprometimento político com a saúde da população aberta: a perspectiva macro-micro ......................................................................................245

3. Brasil: caso paradigmático de reforma pública de saúde na América Latina...........250

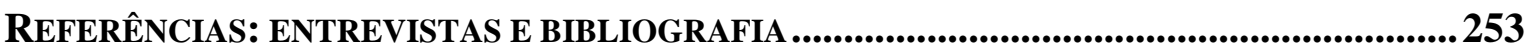

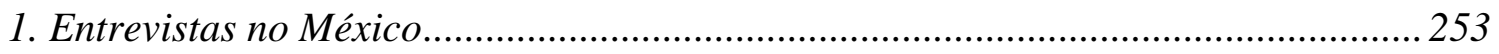

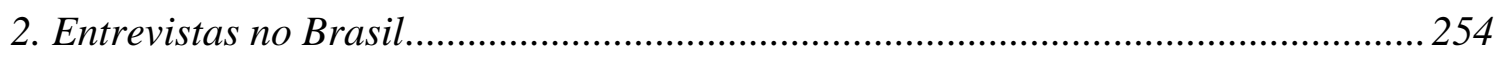

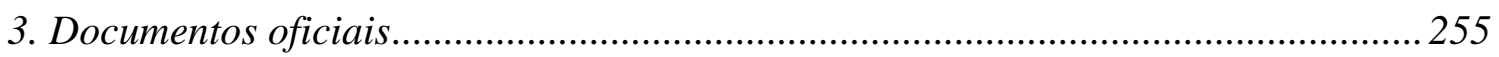

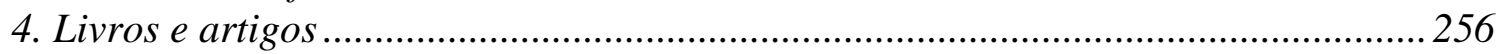




\section{Índice de Quadros e Tabelas}

Quadro 1.1 - Fases da Medicina Preventiva/Social nos países hegemônicos e sua vertente

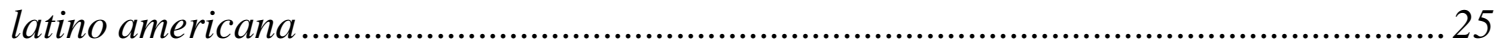

Quadro 1.2. Relações estatais e instituições públicas de saúde no México....................... 35

Tabela 1.1 - População integrada aos serviços de saúde (População coberta em milhões de

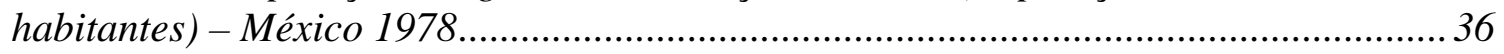

Tabela 1.2 - Unidades Médicas em serviço, segundo tipo e por instituição, 1971. ........38

Tabela 1.3 - População com acesso a serviços de saúde em 1972, Brasil...................... 46

Tabela 1.4 - Hospitais Públicos, Privados Lucrativos e Filantrópicos no Brasil, 196849

Tabela 1.5 - Prontos Socorros e Hospitais no Brasil, 1968 ............................................ 49

Quadro 2.1. Regularidades políticas do processo inicial de redefinição do significado de domínio público-estatal na política de saúde para a população aberta: México e Brasil.88 Quadro 3.1. Tipos participativo e não-participativo de influência direta na decisão macro: segundo o critério "extensão da representação da participação direta na decisão macro"

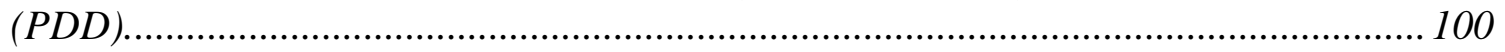

Quadro 3.2. O padrão mais amplo de participação direta na decisão macro na saúde:

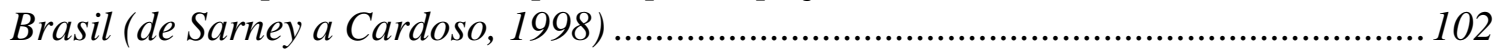

Quadro 3.3. O padrão mais restrito de participação na decisão na saúde: México (de De la

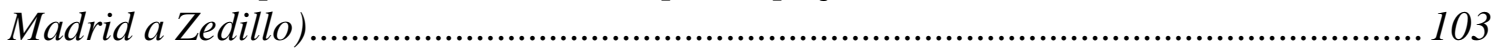

Quadro 3.4 - Variáveis políticas de identificação com a decisão da política macro... 106

Quadro 3.5 - Critérios para a definição dos níveis de identificação com a política macro

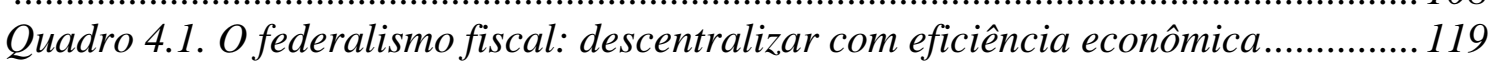

Quadro 4.2 Lei Geral de Saúde de 1984: as bases da reforma ...................................... 122

Quadro 6.1. Políticas de Segunda Geração: combater a pobreza e criar regras

institucionais para o crescimento do mercado............................................................ 147

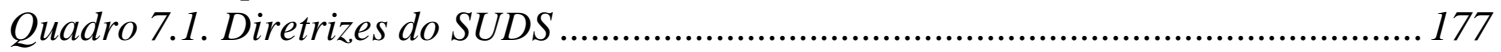

Quadro 7.2 - A Saúde no orçamento da Seguridade Social: Constituição de 1988...... 190

Quadro 7.3 - O Sistema Único de Saúde na Constituição de 1988 - resumo.................191

Quadro 8.1. Diretrizes da reforma sanitária versus diretrizes do neoliberalismo econômico

Quadro 11.1- Identificação e legitimação: avaliação política e comparativa do processo da reforma pública de saúde para a população aberta no México e no Brasil .... 243 


\section{Introdução}

A democratização do acesso à atenção pública à saúde para a população aberta (ou nãoassegurada) não apenas compreende um capítulo recente na História mexicana e brasileira, como também apresenta singularidades e semelhanças politicamente significativas entre os países. Dentre as singularidades, destaca-se o fato das reformas de saúde se encontrarem associadas a seqüências distintas de transição política (democratização e liberalização econômica $)^{1}$, em que coalizões políticas e profissionais com conhecimentos singulares na área da saúde - identificados ou com a economia da saúde ou com a Medicina Social - participaram diretamente dos processos de decisão política, na esfera política macro nacional (ou federal), dando origem a reformas de diferentes naturezas e escopos. No que se refere às semelhanças, os novos governos democráticos ou em transição à democracia, ao serem confrontados por situações de crises políticas, - acirradas sobretudo no fim e início de cada governo -, de forma unânime utilizaram a reforma da saúde para a população aberta (ou não-assegurada) e, mais especificamente a estratégia de descentralização, a fim de se re-legitimarem no poder. Entretanto, após praticamente duas décadas de reforma, as novas iniciativas de políticas públicas, revistas e regulamentadas nas distintas fases da reforma em cada país, ainda não foram implementadas, revelando-se incapazes de resolver problemáticas como: a desigualdade no acesso à atenção pública à saúde, e falta de eficiência-econômica e qualidade na oferta de serviços públicos de saúde para a população.

Este trabalho de doutoramento tem por objetivo estudar o processo recente de reforma da política pública de saúde para a população não-assegurada, no México (1982 a 2000) e no Brasil (1985 a 1998), como um processo de legitimação política, em construção nas esferas políticas (macro nacional e micro sub-nacionais) e articulado de forma distinta com a esfera social e econômica. Privilegiaremos a estratégia de descentralização da política pública, utilizada em ambos países para integrar a população não-assegurada ou aberta no pacto político

\footnotetext{
${ }^{1}$ A democratização, desde a etapa de distensão política até a de realização de eleições diretas dos representantes políticos, pode ter ocorrido antes ou depois do processo de liberalização econômica; isto é de influência direta dos preceitos da economia neoclássica, mais conhecida como neoliberalismo, sobre as diversas políticas públicas do país. O efeito político prático das distintas sequiências da dupla transição política vivida pelos países encontra-se no fato de que a lógica (ideologia, tipo de conhecimento, "espírito") do processo posto em marcha inicialmente, tender a mostrar-se, na prática política, determinante em relação àquele iniciado posteriormente. Um dos argumentos deste trabalho é que, apesar do caráter politicamente dominante adquirido pela globalização econômica, estas associações variam no decorrer do tempo (de mudança), apresentando configurações distintas nos países.
} 
estatal, por meio do incremento da democratização dos serviços público-estatais de saúde. Conceituamos a descentralização ${ }^{2}$ como um processo de re-ordenamento do poder político e da sua relação com a sociedade. Trata-se, mais especificamente, da distribuição das responsabilidades de poder de gestão dos serviços de saúde entre as esferas macro (nacional ou federal) e micro (sub-nacional, estadual e/ou municipal), cujos ritmos e formatos dependem da atuação do político, dos administradores/funcionários públicos e dos usuários - no nível micro - em relação às diretrizes construídas no processo decisório macro. No México, esta descentralização do poder foi direcionada para os estados, enquanto no Brasil este processo seguiu sobretudo uma vertente municipalista.

Nossa análise será guiada por um problema analítico central: o processo político de descentralização da política pública da saúde para a população aberta será estudado como um novo processo de legitimação (no domínio público-estatal de saúde) - o qual requer não apenas uma nova construção político-institucional de bases de legalidade (leis constitucionais, regulamentações e programas), como também uma nova construção social, isto é: mudança nos valores e atitudes por parte daqueles que participam do processo da política pública de saúde nas duas sociedades, cujos domínios públicos não apenas foram construídos como domínio público-estatal ${ }^{3}$, como também têm sido organizados segundo uma lógica política de cunho patrimonialista. Este padrão de relacionamento Estado/Sociedade, como veremos, mantém-se (mesmo em distintas proporções) tanto em formas de governo autoritárias, como em períodos de transição de regime político e de democratização nos dois países (Malloy, 1985, 1986, 1999) (Schwartzman, 1982).

A relevância em se estudar o recente processo de reforma pública de saúde como um problema de legitimação política encontra-se no fato de México e Brasil - países

\footnotetext{
${ }^{2}$ Como reconhece a literatura de descentralização ou federalismo, as políticas de descentralização adotadas nas duas últimas décadas (como as de saúde), resultaram em formas distintas e incompletas de autonomia política e econômica na transferência de responsabilidades administrativas, de gestão de políticas e de competências fiscais (de arrecadação e de gasto) da esfera central para as esferas sub-nacionais de governo. A descentralização, portanto, é geralmente conceituada como um processo complexo que "implica um conjunto de vertentes que passa pelo econômico-regional, por processos de ajuste entre atores políticos, por sistemas de relações sociais locais" (Cabrero, 1998, p. 81). Sobre o conceito de federalismo fiscal, veja o Quadro 4.1, no Capítulo 4. Para diversas definições de descentralização veja Cabrero (1998), Rondinelli (1999), Shah (1999) e Ford (1999) na bibliografia. Sobre a contribuição da Ciência Política na análise do federalismo, veja Elazar (1987), Riker (1975), Weingast (1995) e Stepan (1997), na bibliografia.

${ }^{3}$ Veja primeiro capítulo e, em particular o texto de Malloy, na bibliografia, em que compara o sistema público de saúde da América Latina com o dos Estados Unidos.
} 
caracterizados pela extrema desigualdade social - terem realizado uma integração social ainda crítica de parcela significativa da população na política e, mais especificamente, no que diz respeito ao acesso aos serviços público-estatais de saúde para a população não-assegurada. Segundo dados da CEPAL (Tabela 1), enquanto os $40 \%$ mais pobres recebiam apenas 10,10\% da renda total brasileira em 1999, os $10 \%$ mais ricos reuniram $47,1 \%$ naquele mesmo ano. No México, os $40 \%$ mais pobres ficaram com apenas 15,1\% da renda total do país em 1998, enquanto os $10 \%$ mais ricos acumularam 36,7\% naquele ano. Esta concentração da renda contribuiu, nos últimos anos ${ }^{4}$, para o incremento do número de pessoas dependentes de serviços público-estatais de saúde nos dois países.

Tabela 1 - Distribuição de Renda por Domicílios no México e no Brasil, 1990-1999 (em \%)

\begin{tabular}{|c|c|c|c|c|c|}
\hline \multirow[b]{2}{*}{ País } & \multirow[b]{2}{*}{ Ano } & \multicolumn{4}{|c|}{ Participação na renda total dos: } \\
\hline & & $40 \%$ mais pobres & $30 \%$ seguintes & $\begin{array}{l}20 \% \text { anteriores ao } 10 \% \\
\text { mais ricos }\end{array}$ & $10 \%$ mais ricos \\
\hline \multirow[t]{3}{*}{ Brasil } & 1990 & 9,5 & 18,6 & 28,0 & 43,9 \\
\hline & 1996 & 9,9 & 17,7 & 26,5 & 46,0 \\
\hline & 1999 & 10,1 & 17,3 & 25,5 & 47,1 \\
\hline \multirow[t]{3}{*}{ México } & 1989 & 15,8 & 22,5 & 25,1 & 36,6 \\
\hline & 1994 & 15,3 & 22,9 & 26,1 & 35,6 \\
\hline & 1998 & 15,1 & 22,7 & 25,6 & 36,7 \\
\hline
\end{tabular}

CEPAL (2001), Panorama Social de América Latina 2000-2001. Santiago, p. 69

No México, dados da Encuesta Nacional de Salud II de 1994 revelam que 59,5\% da população não possuía nenhum seguro de saúde (público ou privado), mostrando-se assim dependente do sub-sistema de saúde da Secretaria de Saúde (SSA) - dirigido para a população não assegurada. Esta condição atingia em média 77,8\% da população nos estados de Hidalgo, Oaxaca, Guerrero e Chiapas. Fatores como baixo nível econômico, nível de renda inferior a cinco salários, usuários não idosos e habitantes da comunidade rural são os que mais caracterizam os usuários dos serviços da SSA.

No Brasil, por sua vez, a implementação do Sistema Único de Saúde (SUS) nos municípios ocorre numa época em que, segundo a publicação Acesso e Utilização do Serviço de Saúde (IBGE/Ministério da Saúde, 1998), 75\% da população não tem nenhum acesso a

\footnotetext{
4 A concentração de renda aumentou acentuadamente nos dois países entre 1986 e 1989, devido aos choques/crises econômicos, associados ao conseqüente acréscimo da taxa de desemprego. Na década de 1990, este crescimento acentuado mostrou-se não uniforme, tendo estabilizado em alguns anos, mas ainda apresentando anos de pico de crescimento, como entre 1997-99 no Brasil e 1995 e 1996 no México. Estes picos se deram em decorrência das políticas de estabilização e de seus efeitos sobre o nível de emprego e distribuição da renda.
} 
plano privado de saúde, logo dependem do SUS. Sendo que quase a metade desses $75 \%$ (isto é; 37,5\% dos usuários do SUS) recebem até três salários mínimos por mês.

Do ponto de vista do conhecimento da literatura, a análise da reforma como um processo de legitimação política justifica-se pelo fato de ainda sabermos pouco sobre a forma como os atores políticos, que ocupam posições de poder nas distintas instituições estatais e países, têm participado diretamente dos processos (de decisão e implementação) da política pública de saúde, respondendo aos desafios vindos à tona na decisão e implementação. Sabemos menos ainda sobre os efeitos que as distintas interações políticas (entre o processo de decisão macro e de decisão e implementação micro da política) exercem sobre a dinâmica dos processos de políticas públicas com naturezas e escopos distintos, nos diferentes países e fases da reforma. Isto quer dizer que um dos grandes desafios para a investigação comparada relaciona-se à compreensão da dinâmica política macro-micro dos processos de mudança concernentes às reformas de saúde nas novas democracias (ou regimes políticos em transição) da América Latina (Capítulo 3).

Tal desafio ressalta não apenas a relevância de análises macro/micro dos processos de políticas públicas (decisão e implementação), como também requer a busca de um marco analítico que possibilite examinar, de modo inter-relacionado, 1) a forma como padrões de decisão política - os quais redundam na produção de políticas cujos escopos variam entre estreitos (focalizados) e amplos (universais ou radicais) - têm impactado os processos políticos de implementação; e 2) o modo como os distintos padrões de decisão têm respondido aos novos e velhos problemas vindos à tona no decorrer das distintas fases de implementação nas novas democracias ou regimes em transição.

Dividiremos o processo de reforma em cada país em distintas fases políticas, relacionadas aos períodos de mudança no poder na esfera política macro nacional - isto é; o governo federal -, uma vez que se trata ou de períodos de crise de governabilidade e/ou de tempos de renovação das expectativas da população em relação à política macro nacional e, mais especificamente, no que diz respeito à possibilidade de acesso às políticas de saúde nos dois países. Ademais, as crises de governabilidade - acirradas no início e fim de cada governo têm produzido alterações nas relações Estado/Sociedade, em especial no que diz respeito à influência da economia ortodoxa (como conhecimento e prática política) na condução das políticas públicas de saúde nacionais. Estudaremos os anos dos governos de De la Madrid, 
Salinas e Zedillo, no México, e os governos de Sarney Collor, Itamar e Cardoso ( $1^{\circ}$ governo) no Brasil.

Metodologicamente, os conceitos utilizados estarão estruturados numa análise típica de relação Estado/Sociedade, a ser efetuada separadamente para cada país e de forma comparada, no final de cada capítulo (nas Partes II e III) e conclusão. Estabeleceremos conexões analíticas entre "padrões de participação direta na decisão macro” - no nível nacional - e "níveis de identificação no processo político micro”, ocorrido na esfera política estadual no México e municipal (sobretudo) no Brasil. Seguiremos uma estratégia dupla. Investigaremos a forma como os atores políticos (especialistas de saúde, políticos, burocratas) participam diretamente do processo de decisão no nível macro (nacional), em distintos períodos de governo e tempos seqüenciais de transição política. Em seguida verificaremos se e em que termos os participantes do processo de decisão e implementação nas esferas políticas micro (políticos, administradores, funcionários e usuários) se identificam com os valores e diretrizes concernentes às legalidades criadas (normas, legislações) na esfera política macro nacional (pela Presidência, Congresso, Ministério da Fazenda e/ou autoridade sanitária do país). As tensões políticas existentes entre diretrizes macro nacionais e prática política micro serão utilizadas para apontarmos níveis distintos de identificação com as estratégias reivindicadas pelas autoridades no nível macro ${ }^{5}$.

O trabalho se encontra dividido em três grandes partes e conclusão final. Três capítulos compreendem a primeira parte do trabalho, intitulada “A Política pública de saúde como uma construção política: comprando México e Brasil”. Nesta parte estaremos desenvolvendo os principais argumentos, conceitos e hipóteses da análise. No primeiro capítulo, ressaltaremos as especificidades políticas de Brasil e México no que se refere ao significado e configuração dos respectivos domínios públicos de saúde, no período anterior à gênese das reformas, e mais especificamente no início da década de setenta. Já no segundo capítulo, estudaremos a gênese do processo de construção da descentralização nos dois países, já inseridos em distintas seqüências de dupla transição política. O intuito é ressaltar algumas regularidades políticas do processo inicial de reforma (nos governos de Geisel e Figueiredo no Brasil, e de Echeverría e Portillo no México) para, então, no quarto capítulo, apresentarmos os principais conceitos (padrões de participação direta, níveis de identificação e legitimação) e

\footnotetext{
${ }^{5}$ A metodologia encontra-se detalhada no $3^{\circ}$ Capítulo.
} 
metodologia a serem utilizadas na análise das reformas a partir de meados dos anos 80 até o final dos anos 90, nos dois países.

Na segunda parte efetuaremos a análise do processo de construção política da descentralização e reforma da política pública de saúde no México. Esta análise se encontrará dividida em três capítulos, relacionados às três fases políticas da reforma mexicana: os anos do governo de De La Madrid, de Carlos Salinas e de Ernesto Zedillo. Já na terceira parte, estudaremos o processo de legitimação da reforma brasileira em quatro capítulos, concernentes aos governos de José Sarney, Collor de Mello, Itamar Franco e Fernando Henrique Cardoso ( $1^{0}$ governo, até 1998). Finalmente, na conclusão, faremos uma revisão da dinâmica das reformas nos dois países, separadamente e de forma comparativa e, em seguida, estabeleceremos conexões entre níveis de identificação, legitimidade e comprometimento político com a saúde da população aberta, na perspectiva macro-micro. 
PARTE I - A política pública de saúde como construção política e social: comparando México e Brasil 


\section{Capítulo 1 - Estado, autoritarismo e política pública de saúde na periferia do capitalismo: México e Brasil}

Até o início dos anos 70 México e Brasil não haviam logrado estender o acesso públicoestatal de assistência à saúde para quase um terço da população. Embora em distintas proporções, suas políticas públicas de saúde consistiam decisões centralizadas nos governos federais, e politicamente orientadas para a classe trabalhadora urbana. O objetivo deste capítulo é evidenciar a forma como se dava a interação entre a esfera política e as esferas econômicas e sociais, em dois Estados de matriz-cêntrica no princípio dos anos 70 sobretudo. Pretendemos não apenas discutir as variações na natureza e escopo ${ }^{6}$ dos sistemas públicos de saúde, como também ressaltar padrões de participação institucionalizados na administração pública-estatal.

Nas distintas áreas do bem-estar social, como a saúde, a conquista de novos direitos sociais e formas de cidadania deriva de processos lentos e não uniformes, em que representantes dos interesses do mercado e/ou das massas e classe trabalhadora se inseriram nas estruturas estatais, pressionando pela criação, manutenção ou reforma de diferentes modelos públicos de assistência à saúde da população. De forma que se mostra politicamente significativo o fato dos domínios públicos de saúde apresentarem não apenas distintos níveis de integração social ou escopos, como também possuírem naturezas diferentes, no que se refere às atribuições de responsabilidades entre o setor médico privado e o setor estatal de saúde.

O principal argumento deste capítulo é que os vínculos existentes entre relações Estado/sociedade e regime político, em distintas etapas do capitalismo e sob específicas condições de comando ou influência do mercado internacional, mostram-se determinantes para a compreensão da forma como se deu a origem e desenvolvimento das políticas públicas de saúde, tal como a conhecemos atualmente. Trata-se de processos políticos que, embora de modo distinto, têm possibilitado ou a democratização (via Estado ou mercado) ou a extensão privilegiada do acesso da população a serviços de saúde, mas que, de forma semelhante, têm resultado na alocação de grande parte dos recursos da economia para a atenção médica

\footnotetext{
${ }^{6} \mathrm{O}$ escopo da política pública relaciona-se à amplitude com que se deu a integração política nos sistemas de saúde, já a sua natureza exprime a distribuição de responsabilidades entre o setor privado e governamental na oferta de serviços público de saúde.
} 
curativa, articulada com um dos setores mais dinâmicos da esfera econômica: a indústria de insumos e equipamentos médicos ${ }^{7}$.

\section{Saúde Pública e Medicina curativa na democratização do acesso à saúde nos países desenvolvidos}

Nos países desenvolvidos, este processo de desenvolvimento de domínios públicos na Saúde relaciona-se a dois períodos longos de transformações políticas e sócio-econômicas, com lógicas distintas de redistribuição dos recursos e de integração social no setor Saúde. O primeiro período compreendeu a origem e hegemonia da Saúde Pública ou Medicina Preventiva, que coincidiu com o processo de construção da democracia política e social e de transição para o capitalismo. Já o segundo período, por sua vez, compreendeu a consolidação e hegemonia da Medicina curativa, que se deu concomitantemente à consolidação das velhas democracias, numa etapa mais avançada do capitalismo.

\subsection{Saúde Pública e o princípio da construção da cidadania nas velhas democracias: a primeira longa etapa das reformas públicas de saúde}

Para se compreender o porquê da dificuldade de se implementar nos dias atuais as reformas públicas de saúde nas novas democracias ou regimes políticos em transição, torna-se necessário reconhecer, primeiramente, que as pressões pela (re)definição de políticas públicas decorrem de culturas/concepções distintas, porém complementares, da Medicina. Trata-se da luta secular entre o cuidar preventivo e o curativo, simbolizado na cultura grega pelas filhas de Esculápio: Higéia e Panacéia. Esta luta traduz-se na prática em formas de socialização do processo saúde/doença, isto é, de conciliação da prática preventiva com a curativa. Tais formas modificaram-se de modo acentuado desde o final do século XVIII, com o advento do capitalismo e a conseqüente super população dos centros urbanos. Foi em decorrência da extrema situação de pobreza dos guetos urbanos, da falta de condições mínimas de higiene e do conseqüente surgimento de novas/velhas epidemias que a saúde se tornou de fato uma questão pública, nos diversos países da Europa e nos Estados Unidos (Quadro 1.1).

Tratou-se do período de origem das sociedades de Saúde Pública nos Estados Unidos e das Sociedades de Medicina Social na Inglaterra (Rosen, 1994) (Lane, 2001), cujos

\footnotetext{
${ }^{7}$ Mais recentemente, com a globalização financeira, a articulação também passou a se dar com o mercado financeiro de seguros médicos.
} 
representantes lideraram movimentos sociais de saúde, os quais foram organizados de forma autônoma à esfera política. Ademais, este processo coincidiu e foi impulsionado pela construção da democracia política e social. Havia neste período uma relação estreita entre ambas culturas médicas - a preventiva e a curativa-, porém uma alta dependência de Panacéia em relação a Higéia. Esta era o foco não apenas da prática e da investigação médica predominante até o século XIX, como também das decisões políticas em relação à Saúde (Quadro 1.1.).

Quadro 1.1 - Fases da Medicina Preventiva/Social nos países hegemônicos e sua vertente latino americana

\begin{tabular}{ll}
\hline \multicolumn{1}{c}{$\begin{array}{c}\text { Vertentes da } \\
\text { medicina preventiva }\end{array}$} & \multicolumn{1}{c}{ Tempo Histórico } \\
\hline Controle sanitário e & Primórdios do capitalismo século XVIII \\
pobreza (1) (2) & e início XIX. \\
Sociedades/Escolas & $\begin{array}{l}\text { Originada no início século XIX e } \\
\text { modifica sua forma de atuação em } \\
\text { de Higiene (1) }\end{array}$ \\
& $\begin{array}{l}\text { virtudes das descobertas na área } \\
\text { epidemiológica. }\end{array}$
\end{tabular}

Descobertas na área Epidemiológica (1) (2)

Medicina Social - e sua gênese européia

Saúde Coletiva Latino-Americana (3)
Final do século XIX até meados do XX. Grandes descobertas no campo da microbiologia. Em meio século muda-se rapidamente o conhecimento na medicina. Século XX: Resultado; queda drástica no número de morbidades e mortes, sobretudo nos países desenvolvidos.

(4) Década de 1940/1950, consolida-se primeiramente nos países socialdemocratas europeus, com forte influência do movimento trabalhista e da esquerda - comunista/socialista. (Alemanha, Suécia, Reino Unido) Década de 1970. OPS, Influência do pensamento de Juan César Garcia. Atuação na OPS.
Século XIX: transmitir conhecimentos básicos de higiene, promover o controle sanitário.

Século XX: promover controle sanitário e tornar as novas descobertas (medicamentos e vacinas) acessíveis à população.

1883 (germe do cólera); 1884 (Tétano); 1894 (causas das pragas); 1905 (vacina do cólera); 1906 (Vitaminas identificadas); 1921 (descob. Insulina); 1928 (penicilina, Fleming); 1935 (sulphonomide prontosil); 1942 (produção em massa penicilina USA), 1945 (DDT usado para controle da malária); 1954 vacina da pólio; 1965 (vacina do sarampo).

O desafio não é meramente de caráter preventivo, mas na conciliação da prevenção com a cura, levando em conta as determinações sociais do processo saúdedoença.

Levar em conta a especificidade da determinação econômica e sócio-cultural latino-americana: extrema desigualdade social e econômica refletida nas condições de saúde de grande parte da população.

Fontes: (1) George Rosen (1994) Uma História da Saúde Pública, Editora da UNESP; (2) Peter Mantin \& Richard Pulley (1997) Medicine Through the Ages, Stanley Jones Publishers, London; (3) Everardo D. Nunes (1999) Sobre a Sociologia da Saúde, Hucitec; e (4) Nick Manning (1999) "Welfare, Ideology and Social Theory”, In: BALDOCK et al. (orgs.) Social Policy, Oxford University Press, p.63-90. 


\subsection{Reforma de saúde e consolidação da democracia social no século XX: Estado versus mercado nos Estados Unidos e Inglaterra}

O domínio de Higéia sobre Panacéia modificou-se paulatinamente, e sobretudo no fim do século XIX, com o advento de descobertas epidemiológicas e com o surgimento de novas tecnologias de saúde. Ao se modificar a correlação existente entre a prática preventiva e curativa, esta passou então a comandar as formas de intervenção sobre o processo saúde/doença no mundo capitalista. A saúde passou a ter seu significado orientado dominantemente não apenas pela atuação de especialistas de saúde pública (ou medicina preventiva) e de um setor privado de atenção médica, mas também de forma expressiva pela atuação de uma indústria da saúde. De modo que a evolução da própria ciência médica, e sua crescente vinculação com mercado no capitalismo, fazem com que a Saúde tenda a se configurar menos como Higéia e mais como Panacéia no decorrer do tempo.

É importante enfatizar, assim, que foi em meio às novas pressões desencadeadas por mudanças no conhecimento da Medicina, e em decorrência dos efeitos socioeconômicos da crise dos anos 30, que a saúde curativa tornou-se hegemônica como política pública, juntamente com a criação dos sistemas nacionais de saúde e de bem-estar social (Quadro 1.1). Estas reformas sociais iniciadas nos países desenvolvidos, no século XX, são tidas como marcos referenciais iniciais da política pública de saúde, como a compreendemos hodiernamente. Devido ao vínculo existente entre conhecimento médico-biológico e estruturas econômicas - tanto na produção de conhecimento ou pesquisa, como de serviços -, a pressão dos interesses de mercado sobre o Estado no processo de redefinição da política pública mostrou-se notadamente mais intensa em relação às fases pretéritas do capitalismo. Dependendo da forma como se dá a articulação entre Estado/Sociedade e regime político, a política pública de saúde pode se converter em direito social ou individual.

Nos países em que movimentos de saúde coletiva conseguiram influenciar o poder e/ou cujos líderes converteram-se em atores políticos inserindo-se no espaço estatal, foram os que tiveram políticas sociais mais universais, mais extensivas ao público em geral, como mostra o caso inglês. Na Inglaterra, o Ministro de Saúde trabalhista de esquerda, Aneurin Bevan, teve papel essencial na realização das reformas de saúde, como amplamente conhecido. Ademais, 
estudo recente de John Stewart (1999) ${ }^{8}$ revela que a Associação Médica Socialista (SMA, a atual Associação de Saúde Socialista) impactou de forma determinante o partido trabalhista no decorrer da elaboração do Sistema Nacional de Saúde (NHS). O autor demonstra que o fato da Associação (SMA) ter acolhido como membros os sanitaristas comunistas, vindos da Rússia, e não ter se rendido aos apelos do partido trabalhista, que demandava a expulsão destes membros da SMA, foi essencial para a realização das campanhas e pressões em prol do NHS no Parlamento e Ministério. O estudo mostra ainda que com a ascensão do partido trabalhista ao poder, a SMA ficou marginalizada, sobretudo devido a sua difícil relação com o então Ministro Aneurin Bevan.

Há que se destacar ainda que apesar desta “difícil relação” do Ministério com o movimento contra-hegemônico (na época) em saúde, o NHS manteve-se como tal por praticamente quatro décadas (40 e 70), devido ao alto grau de consenso existente na política em relação ao sistema (Miller, 1999). Quando se verificava uma alteração no governo, o novo partido não efetuava mudanças radicais na política devido à existência deste consenso (Miller, 1999, p.24). Com o NHS a política trabalhista havia legalizado um domínio público que se encontrava em construção na esfera social desde o século 17 e, na esfera política, basicamente desde a reforma de Chadwick em 1842, após o surto do cólera9 ${ }^{9}$

Já nos países em que associações de saúde se articularam com o setor médico privado, no decorrer do seu crescimento, a política de saúde foi definida pela atuação dos lobbies deste setor na esfera política estatal, como ocorreu nos Estados Unidos. Neste país, coube ao governo apenas a responsabilidade pelos serviços de saúde dos pobres, por meio do programa MEDICAID, e dos aposentados, mediante o MEDICARE. Encontram-se fora do sistema de função governamental as pessoas que não apresentam uma situação de extrema pobreza (para serem beneficiários do MEDICAID), e as que não têm condições para adquirirem individualmente um seguro privado de saúde. O sistema de saúde hegemônico não é o de função governamental, mas o de responsabilidade do setor privado. Trata-se de um sistema

\footnotetext{
${ }^{8}$ Veja o livro de J. Stewart: The Battle for Health: A Political History of the Socialist Medical Association (193051), Ashgate, London, 1999

${ }^{9}$ Veja Lane (2001) na bibliografia, e também o trabalho de Michael D. Warren: A Chronology of State Medicine, Public Health, Welfare and Related Services in Britain: 1066 - 1999, disponível em http://www.chronology.org.uk/, acesso em julho de 2004.
} 
baseado no seguro-saúde privado ${ }^{10}$, em que a atenção à saúde compreende sobretudo um direito individual, realizado mediante a inserção do indivíduo no mercado de planos/seguros médicos privados, onde vigora a prática de uma medicina pessoal de alta tecnologia e de custo elevado $^{11}$.

Já no modelo inglês, a atenção pública à saúde consiste em direito social realizado de forma indiscriminada pelas instituições do Sistema Nacional de Saúde (NHS), em que prevalece a prática da medicina coletiva ${ }^{12}$. Tais modelos públicos surgiram em diferentes democracias, em épocas de grandes mudanças políticas e econômicas, compreendendo padrões distintos de interação e de luta entre a esfera política, a esfera econômica e a esfera social. Certamente a prática preventiva assumiu novos formatos em cada país. No entanto, a questão da prevenção da saúde de grande parte da população não se mostrava mais como desafio, como no século XIX. Ademais, Higéia não mais se relacionava a condições de extrema pobreza.

Observe que, tanto nos Estados Unidos quanto na Inglaterra, a criação do sistema público de saúde associa-se diretamente com a forma de governo democrática, em sociedades onde já haviam sido construídos os requisitos necessários para a consolidação da democracia tais como: 1) uma sociedade civil autônoma, 2) uma sociedade política autônoma e valorizada, 3) um Estado de direito para assegurar as liberdades e garantias dos cidadãos, 4) uma sociedade econômica autônoma institucionalizada e 5) burocracias que pudessem ser utilizadas pelo novo grupo democrático (Stepan e Linz, 1999) (Weffort, 1994). Políticas públicas de saúde de distintas naturezas integraram a população aos serviços de saúde ${ }^{13}$. Esta democratização deu-se ou via Estado, para a sociedade em geral, ou via mercado (sobretudo) para grande parte da sociedade. Trata-se de países onde foram formadas sociedades de base individualista. No entanto, tendo em vista o caráter diferencial das relações Estado/sociedade, no que se refere

\footnotetext{
${ }^{10} \mathrm{O}$ padrão americano de política de saúde será ardorosamente defendido por importantes atores sociais, a partir dos anos oitenta, enquanto a panacéia para a reorganização da atenção da saúde.

11 Trata-se do sistema que exibe um maior gasto per cápita dentre os países da OCDE e, ao mesmo tempo, taxas de cobertura e indicadores sanitários fortemente insatisfatórios. Ademais, nos EUA tempos menores de internações (controlados através do Managed Care) subsistem com os maiores custos de internação por dia. Veja texto de Maria Alicia Ugá, “Gasto, acesso e condições de saúde: tendências nos países da OECD”. Revista da Associação Médica Brasileira. Vol. 47 n. 3 São Paulo Julho/Setembro, 2001.

12 Diferentemente da saúde pessoal, os serviços de saúde coletiva consistem em ações destinadas a melhorar as condições gerais de saúde e de vida da coletividade em geral.

13 A natureza da política pública exprime a distribuição de responsabilidades entre o setor privado e governamental na oferta de serviços público de saúde.
} 
mais especificamente ao setor Saúde, foi politicamente possível na Inglaterra criar um sistema público de domínio estatal, enquanto nos Estados Unidos, deu-se a produção de um sistema público de domínio (hegemonicamente) privado no setor saúde.

Ressaltamos que o surgimento das políticas públicas de saúde no pós 1930, nestes dois países desenvolvidos, ocorreu após um longo processo de construção política - de direitos políticos e sociais -, em sociedades cujas esferas da sociedade civil e da sociedade econômica possuíam um alto grau de autonomia em relação à esfera política. A política pública de saúde pode ser definida, assim, como um processo específico de luta em que atores identificados com os interesses individualistas do mercado e/ou com os interesses coletivos da sociedade civil procuram influenciar o processo de decisão da política pública, no intuito de criar/rever legislações e, assim, (re)definir a alocação dos recursos político-econômicos no setor.

\section{Estado e medicina curativa na periferia do capitalismo: México e Brasil}

Na periferia do capitalismo, por sua vez, a atenção curativa da saúde também surgiu de forma mais expressiva após 1930/1940. Isto é: no mesmo tempo cronológico em que se deu no mundo desenvolvido, mas num tempo em que a prática preventiva ainda mostrava-se precária e inacessível a grande parte da população. No México e no Brasil, a construção política dos respectivos sistemas de saúde foi orientada por atores já inseridos na esfera política, com a criação de instituições estatais destinadas a desempenhar a função do curar público na saúde ${ }^{14}$. Isto ocorreu sem que houvesse a influência direta (na esfera política) de movimentos/organizações sociais críticos às condições de saúde vigentes, como na Inglaterra, e sem que houvesse a conformação prévia de políticas mais igualitárias de distribuição da renda, que poderiam ter possibilitado uma integração social via mercado. Diferentemente do caso inglês, no México e no Brasil a criação de um sistema público eminentemente curativo não implicou na realização de direitos sociais na saúde, visto que grande parte da população ainda não havia sido integrada aos respectivos sistemas até os anos 70. Após os anos 30/40, a construção política dos sistemas públicos mostrou-se orientada, de modo semelhante, por

\footnotetext{
${ }^{14}$ No fim do século XIX/início do XX o cuidado público com a saúde nasceu praticamente reduzido às atividades de controle sanitário.
} 
padrões autoritários de interação entre esfera social, econômica e estatal nos dois países da periferia do capitalismo.

Esta interação, na América Latina, tem sido caracterizada como uma atuação típica de sociedades de matriz Estado-cêntrica ${ }^{15}$ (Cavarozzi, 1994 e 1996). Segundo este conceito, a esfera política organiza-se de modo tendencialmente centralizado, articulando-se não apenas de forma privilegiada com os interesses da esfera econômica, como também em detrimento dos interesses mais amplos da esfera social. Este tipo de interação ressalta a existência de uma relação social perversa, mas politicamente significativa, entre crescimento econômico e sistema político. O crescimento econômico mostra-se essencial ao processo de legitimação de regimes e de sustentação de alianças políticas ${ }^{16}$. No entanto, o desenvolvimento econômico ocorre sem que se viabilize politicamente o desenvolvimento social, isto é: a integração da população na política pela via do Estado ou do mercado. O Estado tende a produzir políticas públicas direcionadas para os setores vistos como risco para a estabilidade do poder constituído e/ou ou necessários ao processo de dominação vigente.

Ademais, a participação dos atores tradicionais a cada sistema público - os quais resistirão ao processo de reforma nos anos seguintes -, tem sido caracterizada por padrões de intermediação como clientelismo e paternalismo, os quais contribuíram para a

\footnotetext{
${ }^{15}$ A matriz Estado-cêntrica (MEC) caracteriza-se pelos seguintes fatores políticos de mudança: 1) A legitimidade dos regimes políticos dependia da capacidade do Estado administrar e/ou distribuir os recursos da economia, bem como de seus respectivos marcos fundacionais, como a Revolução Mexicana. Neste sentido, os mecanismos monetários e fiscais utilizados pelo governo mostravam-se condicionados pela forma como as relações políticas eram produzidas na MEC. 2) As instituições políticas da MEC não se mostram eficazes para resolver os conflitos existentes, sendo caracterizadas pela instabilidade institucional. 3) A inclusão ou incremento do espaço de participação política da sociedade civil ocorreu mediante a articulação de diferentes mecanismos de controle político e sócio-cultural, que foram implementados ou redefinidos pelo estado (Cavarozzi, 1994 e 1996). O conceito de matriz Estado-cêntrica, formulado por Cavarozzi, refere-se sobretudo "à fórmula política como conflitos de interesses e valores eram resolvidos” (Cavarozzi, 1994, p.148), em cada contexto específico.

${ }^{16}$ A relevância atribuída à dinâmica do Estado nos países da América Latina foi amplamente tratada por Cardoso e Faleto (1999). O papel central do Estado na condução do desenvolvimento econômico destaca-se dentre as problemáticas e elementos analíticos introduzidos em Dependência e Desenvolvimento na América Latina. A interpretação desses autores contribuiu para o desenvolvimento de análises baseadas na noção de Estado desenvolvimentista. Este se caracteriza por promover uma política de exclusão com a sociedade e por manter uma estratégia de intervenção na economia (Stepan, 1988). De acordo com Cardoso e Faleto (1999), para se entender o momento de transição na sociedade é preciso reconhecer não apenas que a crise no modelo de crescimento tenha sido gerada no exterior, mas também verificar a forma como a crise político-social interna do sistema de poder e a crise da economia mundial se articulam na configuração de novas alianças políticas. Na América Latina, os processos de mudança política tendem a ser guiados pela renovação da coalizão política inserida no Estado e caracterizados por alterações no padrão de dependência - a cada momento em que se procura promover avanços no modelo desenvolvimentista (ou nas etapas de industrialização).
} 
institucionalização de práticas políticas que dificultam a tomada de decisões e resolução de conflitos na administração pública-estatal e, assim produzem um alto grau de efeitos inesperados em relação à política intencionada. Estas práticas referem-se a formas de socialização reveladoras do significado de domínio público-estatal na atenção à saúde em cada país.

\section{Autoritarismo pós-revolucionário e política de saúde para a população aberta no México}

"La soberanía nacional reside esencial y originariamente en el pueblo. Todo poder público emana del pueblo y se instituye para beneficio de éste. El pueblo tiene, en todo tiempo, el alienable derecho de alterar o modificar la forma de su gobierno” (Artigo 39, Constituição de 1917).

A construção do sistema público de Saúde no México compreende um processo histórico, sócio-político e cultural, orientado pela forma como a elite política do partido de Estado tem construído políticas e programas que possibilitaram uma integração social seletiva na Saúde, garantida de forma hegemônica para o setor trabalhista, e em menor escala para a população aberta ou não-assegurada. Ademais, o domínio público-estatal na Saúde tem sido orientado por uma lógica organizacional de origem patrimonialista ${ }^{17}$ (Zabludovsky Kuper), como veremos.

A especificidade desta aliança política seletiva, bem como desta prática patrimonialista no domínio público-estatal, que caracterizam as relações Estado/Sociedade, no caso do México, pode ser atribuída praticamente a três fatores políticos inter-relacionados. 1) Destacase primeiramente a longa duração de um regime de partido único ${ }^{18}$ (o partido de Estado), em que o Presidente é o chefe do partido, controla todas as instituições estatais e organizações sociais relacionadas a elas, indica o próximo Presidente e, assim, garante a estabilidade política

\footnotetext{
${ }^{17}$ Domínios políticos de origem patrimonialista são dotadas de um alto nível de tensão entre a racionalidade substantiva (material) e formal (técnica): uma não elimina a outra. A permanência da lógica patrimonialista na administração estatal, no decorrer do processo de “modernização”, impede o desenvolvimento de um cálculo racional nestas sociedades. Uma dos resultados deste tipo de domínio deve-se ao fato dos monopólios públicos (estatais) abafarem ou limitarem a formação de capitais (de um mercado) de forma autônoma do poder. De acordo com Max Weber, é o caráter arbitrário da forma de dominação patrimonial que impede o desenvolvimento do capitalismo industrial privado (competente), e constitui o motivo de debilidade do patrimonialismo do ponto de vista político. Este aspecto negativo impede a calculabilidade indispensável e proporcionadora de mudanças estáveis na política. Veja Weber (1995), Schwartzman (1982) e Zabludovzky Kuper (1993), na bibliografia.

${ }^{18}$ O Partido Revolucionário Institucional (PRI) foi formado em 1929.
} 
e a permanência do partido no poder. Tal processo é legitimado por meio da reiteração constante do compromisso do partido de Estado com a Revolução Mexicana, cujo ideário (na Constituição de 1917) incorporou os interesses das diversas etnias, classes e elites regionais, de um país que passou por anos seguidos de guerras, guerrilhas e de permanente instabilidade.

O autoritarismo mexicano consistiu em regime político de base revolucionária, nacionalista e de partido único. Não compreendeu um autoritarismo de transição, como no caso do Brasil. A Revolução Mexicana nasceu em reação à concentração de renda ${ }^{19}$, e sobretudo da terra, resultante do pensamento liberal vigente no período de Porfírio Diaz. Sua ideologia foi profundamente nacionalista e estatista, daí o porquê de setores hegemônicos do mercado ${ }^{20}$ não terem sido incorporados na política, como ocorreu no Brasil. A ideologia do Estado constituiu, ao mesmo tempo, obra da classe média intelectual, do proletariado em formação, da pequena burguesia, e tem sua originalidade na tentativa do movimento agrário, do Norte e do Sul, de dispor de uma direção política autônoma (Nunes, 1999). Apesar do movimento agrário ter sido derrotado pela “aliança do Constitucionalismo (pequena burguesia) e da casa del Obrero Mundial, estes recuperaram certos elementos do agrarismo, para atrair, em uma fase ulterior, não só os setores da classe camponesa média que não tinham aderido ao viilismo, mas também outras facções da classe camponesa pobre” (Nunes, 1999, p. 151). Trata-se de uma Revolução com características próprias, pois é popular, antiimperialista, nacionalista, agrária e pequenoburguesa.

A ideologia Revolucionaria do partido de Estado se encontra na Constituição de 1917. Esta "funcionou como peça central da nova ordem política. Foi a cristalização especifica das forças que surgiram da Revolução” (Basáñez, 1990, p.191). De acordo com Ben Ross Schneider (1997) a Constituição de 1917 mostra-se politicamente significativa porque ela

\footnotetext{
${ }^{19}$ A distribuição de terras realizadas pelo Estado, por exemplo, já desde o governo de Carranza (1915-20) e sobretudo nos governos de Cárdenas (1934-40) e Camacho (1940-46), produziram, de um lado, uma forte coesão social e legitimidade para o poder instaurado. Também gerou, de outro, a reação do setor privado organizado de forma autônoma ao poder, temeroso que o PRI freasse o investimento na economia, contribuindo para o declínio do crescimento e sobretudo das exportações.

${ }^{20}$ As organizações empresariais foram criadas, no decorrer dos anos, em reação às medidas populistas do governo, coincidindo com passagens importantes da História do México. "A criação de CONCANACO (comerciantes) e CONCAMIN (industriais) em 1918 e 1917, respectivamente, foram respostas ao 'radicalismo" da legislação de 1917 (segundo a percepção dos empresários). O PAN foi criado em 1939 para inserir a linha moderada de Ávila Camacho que a facção econômica havia ganhado por apoiar financeiramente a rebelião de Cedillo e a candidatura presidencial de Almazán (Basáñez, 1990, p.198). Veja o livro de Basáñez, (1990) para uma análise sobre a formação de outros Conselhos e organizações empresariais.
} 
“insere praticamente a maior parte do 'ismos' daquela Era e agora pode ser evocada ao serviço de projetos liberais, de bem comum, patrimonialistas e socialistas” (Schneider, 1997, p.24).

Até a década de 40, praticamente, a ideologia revolucionária limitou de forma determinante o desenvolvimento econômico, mas na medida em que setores populares organizados foram sendo inseridos na política e, mais precisamente, na burocracia de Estado, o PRI, a fim de se legitimar no poder, passou a se comprometer menos com sua base popular ainda não integrada e, assim, deu início a um processo de lenta integração social ou exclusão social das camadas populares não organizadas (Schneider, 1997). De forma contraditória à sua base de legitimidade popular, o exercício de poder do partido de Estado tornou-se progressivamente dependente dos padrões de intermediação política promovidos na burocracia estatal (como corporativismo e clientelismo). Com efeito, a atuação do Estado tem sido caracterizada, de um lado, por um compromisso revolucionário de base popular e, de outro lado, por um compromisso desenvolvimentista - caracterizado antes pelo compromisso com o desenvolvimento capitalista do que com a classe capitalista - o que garantiu basicamente cinqüenta anos de estabilidade política no México (Basáñez, 1990) (Schneider, 1997).

2) É possível afirmar portanto que a despeito de sua ideologia de base revolucionaria popular, após a década de 40 o PRI tem fundado o exercício do seu poder de forma mais objetiva pela intervenção estatal na economia. De acordo com Victor Soria, “As formas institucionais que o presidencialismo e o Partido de Estado trataram de controlar politicamente, de maneira direta e eficaz foram a articulação da agricultura com o crescimento industrial e com a relação salarial, mediante uma estrutura corporativo-clientelista manejada pelos três níveis constitutivos do bloco de poder conformados pela coalizão política. Um controle indireto é exercido sobre as organizações empresariais a através de franquias fiscais, subsídios e contratos com o setor público. As relações monetárias e fiscais-financeiras, assim como as relações internacionais, foram manejadas pela presidência através do gabinete econômico e da consulta ao primeiro nível da coalizão. As formas institucionais tiveram a força para criar e promover as instituições que materializam as formas concretas das relações sociais que permitiram o manejo da economia” (Soria, 1999, p. 122). De forma que era sobretudo por meio de uma política econômica estatista, ou melhor, de estratégias de desenvolvimento/crescimento econômico via Estado, que o partido de Estado se legitimava objetivamente no poder. Por 
praticamente quatro décadas seguidas o PRI logrou produzir políticas de controle de preços e de desenvolvimento econômico caracterizados como sucesso.

3) O controle político institucional estabelecido pelo Partido de Estado permitiu o manejo político da economia e, assim, forneceu ao Estado os instrumentos políticos e econômicos necessários para implementar políticas de bem-estar social. Estas privilegiaram, por fim, a classe trabalhadora, necessária para a realização do desenvolvimento econômico. O processo de integração social das demais camadas sociais - excluídas da aliança corporativa -, por meio de novas políticas sociais, ocorreu de forma paulatina e sempre em reação a eventos sociais que se mostravam como risco ou potencialidade de risco ao poder vigente (Quadro 1.2). As mudanças, sejam na economia, sejam nas políticas sociais e de saúde, se davam sem que houvesse um rompimento da continuidade constitucional. Há que se ressaltar que nestes cinqüenta anos, permaneceu no poder uma “coalizão política revolucionária” (Soria, 1999). Mudanças no sistema público de saúde, como criação de novos institutos ou programas sociais e reformulações no modo de financiamento, visavam garantir a estabilidade necessária à manutenção do processo de dominação, sem que houvesse um rompimento com a forma institucional vigente.

\subsection{A construção de um sistema público-estatal dual de saúde no México}

No México, os interesses corporativos se consolidaram, desde seu início, em programas e instituições controlados pelo Estado e centralizados no âmbito do Governo Federal. As primeiras iniciativas de seguro social surgiram com Cárdenas. Este concedeu um regime de aposentadoria, introduzindo serviços de saúde coletiva para os trabalhadores da PEMEX e para os ferroviários (Quadro 1.2). Em 1933 este tipo de seguro também passou a ser aplicado aos trabalhadores dos serviços de eletricidade. Antes de 1940 ocorreu apenas a implementação de programas de seguros controlados pelo Estado, dirigidos a ramos específicos da economia, sem que houvesse a constituição da previdência social. Cárdenas também criou, em 1937, o Departamento de Assistência e Salubridad Social, dentro da Secretaria de Assistência Social, o qual deveria se ocupar com a tuberculose e iniciar um serviço de prevenção (Quadro 1.2).

De acordo com Malloy (1986), a pressão manifesta pelos grupos sociais salientou-se mais no Brasil, onde já existiam programas que tendiam à multiplicação de fundos mais ou menos autônomos desde os anos 20. Esta pressão também se deu nos estados, sobretudo São 
Paulo e Rio de Janeiro, onde já havia um sistema descentralizado organizado pelos governos estaduais e/ou iniciativas de atendimento, decorrente da existência de institutos de pesquisa de Saúde Pública. No México, por sua vez, o papel assumido pelas elites administrativas (nos anos 30) teve maior destaque desde o princípio. Mostrou-se "mais fácil impor programas de proteção social de acordo com o pensamento mais moderno na época (Segunda Guerra Mundial) sobre a previdência social” (Malloy, 1986, p.156), os quais tendiam à unificação dos

\section{fundos mais diretamente controlados pelo Estado.}

Quadro 1.2. Relações estatais e instituições públicas de saúde no México

\begin{tabular}{|c|c|c|c|c|c|c|c|}
\hline \multicolumn{2}{|c|}{$\begin{array}{c}\text { Mudanças na } \\
\text { MEC } \\
\end{array}$} & \multirow[t]{2}{*}{ Ano } & instituição pub. de saúde & grupo alvo & $\begin{array}{c}\text { financia- } \\
\text { mento }\end{array}$ & $\begin{array}{l}\text { nível da atenção } \\
\text { médica }\end{array}$ & motivação política \\
\hline \multirow{3}{*}{ 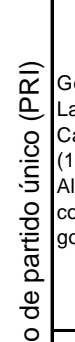 } & \multirow{3}{*}{$\begin{array}{l}\text { Governo de } \\
\text { Lazaro } \\
\text { Cárdenas } \\
\text { (1934-40) - } \\
\text { Altera a } \\
\text { coalizão de } \\
\text { governo }\end{array}$} & & $\begin{array}{l}\text { PEMEX e ferroviários: seguro } \\
\text { seletivo:regime de aponsentadoria } \\
\text { e serviço médico para estas } \\
\text { empresas públicas }\end{array}$ & $\begin{array}{l}\text { Trabalhadores da } \\
\text { PEMEX e } \\
\text { ferroviários }\end{array}$ & $\begin{array}{l}\text { Trabalhador e } \\
\text { governo federal }\end{array}$ & Básico e especializado & $\begin{array}{l}\text { Criar programa de seguro para grupos } \\
\text { específicos, essenciais ao processo } \\
\text { econômico }\end{array}$ \\
\hline & & 1933 & $\begin{array}{l}\text { O seguro também é aplicado aos } \\
\text { trabalhadores dos serviços de } \\
\text { eletricidade, e outros setores } \\
\text { públicos }\end{array}$ & $\begin{array}{l}\text { Trabalhadores da } \\
\text { eletriciade e outros }\end{array}$ & $\begin{array}{l}\text { Trabalhador e } \\
\text { governo federal }\end{array}$ & Idem & Idem \\
\hline & & 1937 & $\begin{array}{l}\text { Departamento de Assistência } \\
\text { Social e Salubridad Social, dentro } \\
\text { da Secretaria de Assistência } \\
\text { Social }\end{array}$ & População geral & $\begin{array}{l}\text { Orçamento } \\
\text { federal }\end{array}$ & $\begin{array}{l}\text { Tratamento da } \\
\text { Tuberculose e iniciar } \\
\text { serviços de prevenção }\end{array}$ & Idem \\
\hline \multirow{3}{*}{ 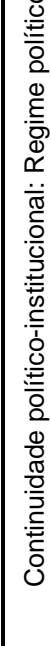 } & \multirow{2}{*}{$\begin{array}{l}\text { Governo de } \\
\text { Camacho } \\
(1940-46) \text { - } \\
\text { Altera a } \\
\text { coalizão de } \\
\text { governo }\end{array}$} & 1943 & $\begin{array}{l}\text { Instituto Mexicano de Seguridade } \\
\text { Social (IMSS) }\end{array}$ & $\begin{array}{l}\text { População } \\
\text { assalariada do } \\
\text { país, com exceção } \\
\text { dos trabalhadores } \\
\text { de áreas } \\
\text { específicas do } \\
\text { serviço público } \\
\text { (que têm seu } \\
\text { próprio seguro) }\end{array}$ & $\begin{array}{l}\text { Orçamento } \\
\text { federal e } \\
\text { captação } \\
\text { forçada, método } \\
\text { de financiamento } \\
\text { regressivo, as } \\
\text { constribuições } \\
\text { estão em } \\
\text { proporção com } \\
\text { os salários. }\end{array}$ & $\begin{array}{l}\text { No IMSS prevalece o } \\
\text { modelo curativo, de } \\
\text { atenção integral, do } \\
\text { nível básico ao mais } \\
\text { especializado.O IMSS é } \\
\text { a instituição que oferece } \\
\text { melhor cobertura aos } \\
\text { trabalhadores, pois é a } \\
\text { que reúne o maior } \\
\text { volume de recursos no } \\
\text { país. }\end{array}$ & $\begin{array}{l}\text { Controle e incorporação corporativa } \\
\text { dos trabalhadores na política. } \\
\text { Consolidou-se um pacto corporativo } \\
\text { que institucionalizou direitos populares, } \\
\text { com a criação de organizaçãoes } \\
\text { sindicais, que incorporou a classe } \\
\text { trabalhadora em um sistema político } \\
\text { de partido único. }\end{array}$ \\
\hline & & 1943 & $\begin{array}{l}\text { Secretaria de Salubridad e } \\
\text { Assistência (SSA). Passa a ser } \\
\text { responsável pela definição, } \\
\text { regulação supervisão; } \\
\text { planejamento estratégico e } \\
\text { provisão de cuidados médicos } \\
\text { para a população não- } \\
\text { assegurada, através de sua } \\
\text { extensa rede de unidades } \\
\text { hospitalares em todo o país } \\
\end{array}$ & $\begin{array}{l}\text { População geral } \\
\text { (não-assegurada) }\end{array}$ & $\begin{array}{l}\text { Orçamento } \\
\text { federal }\end{array}$ & $\begin{array}{l}\text { Predomina a } \\
\text { assistência de primeiro } \\
\text { nível em todo o país. } \\
\text { Os serviços } \\
\text { especializados se } \\
\text { concentram sobretudo } \\
\text { na capital (Institutos da } \\
\text { SSA) }\end{array}$ & $\begin{array}{l}\text { A incorporação da população aberta, } \\
\text { não assegurada, além da trabalhadora } \\
\text { assegurada e sindicalizada, dá } \\
\text { condições políticas para o Estado, ou } \\
\text { melhor, para o PRI manejar a } \\
\text { economia. }\end{array}$ \\
\hline & & 1959 & $\begin{array}{l}\text { Instituto de Seguridade Social dos } \\
\text { Trabalhadores do Estado } \\
\text { (ISSSTE) }\end{array}$ & $\begin{array}{l}\text { Servidores do } \\
\text { Estado }\end{array}$ & $\begin{array}{l}\text { Trabalhador e } \\
\text { governo federal }\end{array}$ & $\begin{array}{l}\text { Integral - básico e } \\
\text { especializado }\end{array}$ & $\begin{array}{l}\text { Controlar mais este segmento da } \\
\text { classe trabalhadora, função ideológica } \\
\text { para o Estado }\end{array}$ \\
\hline
\end{tabular}

Foi apenas no governo de Camacho (1940-1946) que se formou um consenso nacional, entre operários, patrões, empresas seguradoras, técnicos e médicos, para a criação de um seguro social que incorporasse outros ramos da classe trabalhadora. Em 1943 foram criados o atual Instituto Mexicano de Seguro Social (IMSS) e a atual Secretaria de Saúde (Secretaria de Salubridad y Assistência até 1984). Estas instituições resultaram do pacto corporativo que institucionalizou os direitos populares, estimulou a criação de organizações sindicais e os 
incorporou em um sistema político controlado por um partido dominante (Soria, 1995) (Soria, 1999) (Ruíz Velázquez, 2000) (Faleiros, 2000) (FUNSALUD, 1995).

Como resultado deste padrão estado-cêntrico de interação política, suportado já por cinqüenta anos de partido de Estado, por décadas de desenvolvimento econômico e de integração social por meio de compromissos corporativos, a elite priista construiu um sistema de saúde de função e administração eminentemente estatal, em que o significado de público apresenta-se como sinônimo de estatal. Em 1978 as instituições do setor público-estatal, (inseridas nos dois sub-setores públicos: da Seguridade Social e da População Aberta), eram responsáveis conjuntamente pelos serviços (curativos e saúde pública) de praticamente 54,9\% da população, enquanto o setor privado era responsável por apenas 14,9\%. Este sistema de mix estatal privado mas hegemonicamente estatal cobria ao todo 69,9\% da população, sendo que 30,1\% não se encontrava formalmente coberta (Tabela 1.1).

Tabela 1.1 - População integrada aos serviços de saúde (População coberta em milhões de habitantes) - México 1978

\begin{tabular}{|c|c|c|}
\hline Responsabilidade de assistência & $\begin{array}{c}\text { população integrada } \\
\text { (via Estado ou } \\
\text { mercado) } \\
\end{array}$ & $\%$ \\
\hline \multicolumn{3}{|l|}{ 1) INSTITUIÇÕES DO SETOR PÚBLICO-ESTATAL } \\
\hline \multicolumn{3}{|l|}{ I. Sub-setor público da seguridade social } \\
\hline IMSS & 20 & 29,9 \\
\hline ISSSTE & 4,8 & 7,2 \\
\hline Total de I & 24,8 & 37,1 \\
\hline \multicolumn{3}{|l|}{ II. Sub-setor público para população aberta } \\
\hline SSA (Ministério da Saúde) & 10,5 & 15,6 \\
\hline Serviços estatais coordenadas pela SSA & 1,5 & 2,2 \\
\hline Total de II & 36,8 & 17,8 \\
\hline $\begin{array}{l}\text { Total população coberta pelo setor público-estatal } \\
\text { (Total I+Total II) }\end{array}$ & 61,6 & 54,9 \\
\hline 2) INSTITUIÇÕES DO SETOR PRIVADO & 10 & 14,9 \\
\hline POPULAÇÃO COBERTA (1+2) & 46,8 & 69,9 \\
\hline POPULAÇÃO NÃO COBERTA FORMALMENTE & 20,1 & 30,1 \\
\hline Total da população & 66,9 & 100 \\
\hline
\end{tabular}

Fonte: Adaptado de López-Acunã (1980), p. 108. Fonte original: José López Portillo, $2^{\circ}$ Informe de Gobierno, 1978.

A construção de um domínio público-estatal de saúde, e de novos programas e/ou políticas no decorrer do tempo, não resultaram na consolidação de direitos sociais, que se traduziram na igualdade de acesso aos serviços público-estatais. A saúde como direito social 
era garantida majoritariamente nos institutos de seguridade social (IMSS e ISSSTE) e nos grêmios corporativos de atenção médica, que integravam cerca de 37,1\% da população mexicana em $1978^{21}$ (29,9\% no IMSS e 7,2\% no ISSSTE). Em segundo lugar, a política incorporou $17,8 \%$ da população no sub-setor público para a população aberta, por meio dos serviços da SSA (Ministério da Saúde) e nos serviços coordenados pela SSA nos estados.

É o sub-setor corporativo de saúde, e mais especificamente, o sub-setor cuja população alvo se encontra em aliança política efetiva com o Estado, que se mostra hegemônico no país, sendo encabeçado pelo Instituto Mexicano de Seguro Social (IMSS). Esta é a instituição paradigmática da atenção médica pública-estatal no México. É onde as práticas e ações de atenção pública à saúde têm sido socializadas, de forma hegemônica, no decorrer de décadas.

Contraditoriamente, esta política de integração diferenciada via Estado tem sido elaborada e implementada por uma elite governamental que, na ideologia e no discurso, sempre se comprometeu com todas as camadas da sociedade. Na prática política, como veremos, não lutou para que camponeses, indígenas, e população rural e em geral tivessem acesso a serviços mínimos de saúde. A política de saúde para a população não-assegurada funda-se sobretudo numa legitimidade subjetiva, e não de procedimentos. O caráter autoritário da política permitiu que o sistema público-estatal de saúde fosse construído e organizado a partir da própria esfera política, em que os atores foram inseridos e tiveram sua participação controlada pelo próprio Estado. Esta interação política tem se traduzido em processos de decisão/implementação que: 1) privilegiam politicamente a alocação de recursos para o setor público-estatal assegurado, 2) garantem politicamente a inserção da indústria e de setores privados de saúde na construção do público, 3) que controlam o acesso do médico e principalmente do sanitarista a um determinado tipo de saber/prática.

Na década de 70 , a política priista aloca apenas cerca de $20 \%$ do orçamento federal em saúde para o público não assegurado. A maior parte do gasto do governo federal com saúde (cerca de 60\% na década de 1970) é transferida para os serviços médicos da seguridade social, e sobretudo, para o IMSS; apesar das instituições de seguridade social terem uma forma de

\footnotetext{
21 Trata-se das seguintes instituições: Instituto Mexicano de Seguridade Social - IMSS (1943), Instituto de Seguridade Social e Serviços Sociais dos Trabalhadores do Estado - ISSSTE (1959), Petróleos Mexicanos PEMEX, Comissão Federal de Eletricidade - CFE, Ferrocarriles Nacionales - FNM, Ministério da Fazenda e crédito Público - SHCP, Ministério da Marinha - SM, Instituto de Seguridade Social das Forças Armadas Mexicanas - ISSFAM, Dependentes do Ministério de Defesa
} 
financiamento tripartide. Em teoria, mais de 40 milhões de mexicanos deveriam ser atendidos pelo sub-sistema da SSA. No entanto a capacidade de hospitais, de centros assistenciais e de serviços da SSA só conseguia cobrir entre 15 e 18 milhões de pessoas em 1978. A SSA conta apenas com 1.593 centros de saúde e 1.217 casas de saúde em operação (dentre as 2.100 construídas) para atender a população rural. Além disso, apenas 2.600 comunidades, dentre as 97.653 que existem no país, têm acesso a serviços de saúde. Isto significa que mais de 90.000 localidades rurais encontram-se sem serviços públicos de saúde no México em 1971 (LópezAcuña, 1980).

Tabela 1.2 - Unidades Médicas em serviço, segundo tipo e por instituição, 1971.

\begin{tabular}{|c|c|c|c|c|c|c|c|c|c|c|c|c|c|c|c|c|}
\hline & \multicolumn{2}{|c|}{$\begin{array}{l}\text { Hospitais } \\
\text { genais }\end{array}$} & \multicolumn{2}{|c|}{$\begin{array}{c}\text { Hospitais de } \\
\text { especilalidade }\end{array}$} & \multicolumn{2}{|c|}{$\begin{array}{c}\text { Centros de } \\
\text { saúde }\end{array}$} & \multicolumn{2}{|c|}{ Clínicas } & \multicolumn{2}{|c|}{$\begin{array}{c}\begin{array}{c}\text { Postos } \\
\text { socorros }\end{array} \\
\end{array}$} & \multicolumn{2}{|c|}{ Consultórios } & \multicolumn{2}{|c|}{ Otros } & \multicolumn{2}{|c|}{ Total } \\
\hline & Núm. & $\%$ & Núm. & $\%$ & Núm. & $\%$ & Núm. & $\%$ & Núm. & $\%$ & Núm. & $\%$ & Núm. & $\%$ & Núm. & $\%$ \\
\hline Instituições de Seguridade Social & 382 & 27,0 & 15 & 4,0 & - & 0 & 390 & 87,0 & 93 & 74,0 & 155 & 71,8 & 1037 & 93,5 & 2072 & 40,2 \\
\hline IMSS & 286 & 20,3 & 13 & 3,4 & - & 0 & 245 & 54,7 & - & 0,0 & - & 0,0 & 302 & 27,2 & 846 & 16,4 \\
\hline FF.CC & 17 & 1,2 & 1 & 0,3 & - & 0 & 2 & 0,4 & 65 & 51,6 & 8 & 3,7 & - & 0,0 & 93 & 1,8 \\
\hline SDN & 23 & 1,6 & - & 0,0 & - & 0 & - & 0,0 & - & 0,0 & - & 0,0 & 146 & 13,2 & 169 & 3,3 \\
\hline SMN & 13 & 0,9 & - & 0,0 & - & 0 & - & 0,0 & 28 & 22,4 & 32 & 14,9 & 1 & 0,1 & 74 & 1,4 \\
\hline |Instituições de assistência & 514 & 36,4 & 53 & 14,0 & 1460 & 100 & - & 0,0 & - & 0,0 & - & 0,0 & - & 0,0 & 2027 & 39,4 \\
\hline SSA & 505 & 35,8 & 37 & 9,8 & 1460 & 100 & - & 0,0 & - & 0,0 & - & 0,0 & - & 0,0 & 2002 & 38,8 \\
\hline DDF & 9 & 0,6 & 16 & 4,2 & - & 0 & - & 0,0 & - & 0,0 & - & 0,0 & - & 0,0 & 25 & 0,6 \\
\hline
\end{tabular}

Já a assistência médica para o trabalhador formal, bem como para parte da população não-assegurada urbana, é garantida nas cidades por meio de uma rede de 1.412 hospitais gerais $^{22}$, de 377 hospitais especializados localizados nas capitais, e de apenas 126 postos de socorro ao todo, de acordo com dados de 1971. Sendo que os postos de saúde pertencem todos às Instituições de Seguridade Social. A SSA não possui nem sequer um posto de saúde em 1971. Estes exemplos demonstram a enorme desproporção existente não apenas entre o subsetor público-estatal assegurado e não-asseguradao, como também entre o nível secundário e o nível primário da atenção médica. Observe ainda que 93,5\% das camas existentes no país

\footnotetext{
${ }^{22}$ Sendo que 27\% dos Hospitais gerais em 1971 são do Seguro Social, 36\% da Assistencial Social (SSA e DF) e 27\% de particulares, Veja López-Acuña (1980), p. 119.
} 
encontram-se em hospitais, e apenas 6,5\% em unidades de primeiros socorros (Tabela 1.2) (López-Acuña, 1980, p. 119).

É sobretudo por meio deste sistema hospitalocêntrico, em que prevalece a prática médica curativa nos hospitais gerais, que a indústria da saúde participa da construção da atenção médica pública-estatal hegemônica no país. O Instituto Mexicano de Seguro Social (IMSS), bem como os hospitais gerais da SSA, são os grandes consumidores de medicamentos e de tecnologia de saúde (de alta e sobretudo média complexidade ${ }^{23}$ ) no sistema público-estatal de saúde mexicano. Nestas instituições pratica-se uma medicina pessoal, produtora de receitas, de exames, e de hospitalizações. A relação entre médico e paciente traduz-se no cuidar da doença, isto é, na prática de uma medicina curativa de alto custo.

É este domínio público-estatal, de atenção curativa hegemônica no IMSS e na SSA, e marcado pela inexistência da prática assistencialista primária na SSA, que incorpora grande parte dos especialistas da área médica do país. As faculdades de medicina, criadas para atender este sistema público-estatal, têm convênio com os hospitais gerais da SSA e sobretudo com os do IMSS (Soberón-Acevedo, 1999). Não há dentro do próprio seguro social, ou dos hospitais da SSA, uma facção médica que reivindicam mudanças neste tipo de atenção à saúde. Porquanto médicos e trabalhadores encontram-se organizados em sindicatos controlados pelo Estado $^{24}$.

Já os sanitaristas mexicanos terão seu nicho na burocracia da SSA. Esta tem a sua própria escola de saúde pública, da onde recruta seu quadro diretivo. Os sanitaristas encontram-se socialmente organizados em sindicatos, e na Associação Mexicana de Saúde Pública. Eles ainda pensam/exercem a saúde pública sobretudo de acordo com a Escola de

\footnotetext{
${ }^{23}$ A alta complexidade se dá sobretudo nos Institutos Médicos do IMSS e da SSA, localizados no DF. Sendo que o consumo de alta tecnologia é maior na SSA. Esta coordena Institutos mistos, públicos-privados, onde se encontram as pesquisas e a medicina de alta complexidade do país. O setor privado, de forma independente do Estado, não investe em pesquisa, nem em alta tecnologia.

${ }^{24}$ Veja livro de Ricardo Pazas Horcacias (La democracia en Blanco: el movimento médico en México, 1964-1965, Siglo Veintiuno Editores, 1993), sobre o movimento de greve dos médicos do IMSS em 1964 e 65. "Os médicos exigiam democratizar o sindicalismo corporativo, esta demanda visava romper com a hegemonia do Estado na representação social dos trabalhadores e criar uma nova distribuição de poder entre Sociedade e Estado: mais equilibrada e moderna, no sentido da pluralidade representativa do termo" (p.324). "no momento em que começa o movimento social dos médicos, estes recorrem ao seu expediente coletivo de organização profissional e reinforçam estas organizações como uma nova modalidade de organização política: a Associação Mexicana de Médicos Residentes Internos, a Associação de Médicos mexicanos. Entretanto, meses após, “o movimento retornou ao hospital como espaço seguro frente a repressão estatal” (p.322)
} 
Higiene $^{25}$. Trata-se de uma vertente conservadora do pensamento em saúde, pois limita a saúde pública a medidas de controle sanitário e epidemiológico (Lopez-Arellano, entrevista 2003).

Este tipo de interação social entre o profissional de saúde pública e o Estado não possibilita o surgimento de movimentos sanitaristas críticos no México até os anos 70. A prática do saber sanitarista de tipo epidemiológico pode se dar de forma pontual, em lugares de foco das epidemias, sem que haja uma interação mais longa com a sociedade ou comunidade local. Ademais, sempre que fizeram greve, suas reivindicações não foram por mudanças no modelo de assistência à saúde. Estes movimentos caracterizavam-se como uma mobilização da categoria, reivindicando aumento salarial e/ou melhores condições de trabalho. Trata-se de uma mobilização corporativa, realizada dentro do próprio Estado. Os velhos sanitaristas do PRI não lideraram, portanto, um movimento social autônomo, fora do Estado, que reivindicasse a extensão ou democratização do domínio público-estatal para as demais camadas populares.

Ademais, o saber crítico em saúde pública que emergiu no México, institucionalizado com a criação do Mestrado em Medicina Social da UAM-Xichimilco em 1974, foi mantido a margem do poder de influência do Estado priista. Porquanto não há espaço para um agir crítico de saúde coletiva na estrutura política do País. Daí ser possível entender a trajetória peculiar da saúde coletiva mexicana: acadêmica e intra-partdária na esquerda (PRD). Este novo grupo de saúde coletiva vai desenvolver uma prática acadêmica influente na América Latina, crítica em relação ao modelo neoliberal. No entanto, se encontrará isolado do domínio de poder, uma vez que não há espaço para uma representação social e participação política mais plural e direta na esfera política dominada pelo $\mathrm{PRI}^{26}$.

Numa sociedade sem movimentos coletivos em saúde, e em que uma política autoritária influência a condução da atenção médica, o processo de socialização no atendimento à saúde esconde efeitos perversos, raramente revelados ao público, mas que virão à tona no decorrer da lenta abertura política e, sobretudo, na democratização com Fox.

Evidencia-se primeiramente a existência de um processo de cristalização de interesses no âmbito das principais instituições do sistema: IMSS e SSA. Estas instituições sempre

\footnotetext{
${ }^{25}$ É possível que esta associação tenha começado a se reorganizar após as reformas de 1984 (tal como indicam as atas de reuniões disponíveis na página de Internet), após terem sido postas á margem do processo de decisão da política pública do país, em meio a ascensão de um novo grupo hegemônico articulado com o mercado e com a nova coalizão política no poder.

${ }^{26}$ Esta situação modifica-se lentamente no decorrer dos anos, com a inserção de representantes do grupo no PRD, e de forma um pouco mais acentuada após 2001, quando Asa Cristina Laurell assume a Secretaria de Saúde do Governo do Distrito Federal, no governo de López Obrador (PRD).
} 
funcionaram de forma independente, porquanto consistiram moedas de troca política dirigida a distintos grupos sociais. A ausência de inter-relação entre os sub-sistemas fazia parte da estratégia de controle político mantida pelo Executivo sobre distintos grupos da sociedade (Ward, 1989). Ademais, estas instituições também consistiram espaço de negociação política entre pares e grupos políticos associados ao PRI. As posições de liderança do IMSS, nos estados e na capital, são cargos de confiança do Executivo, alternados ou não na mudança dos sexênios.

Tanto no IMSS quanto na SSA a atenção à saúde é realizada com recursos do governo federal, mas sem que haja uma prática de prestar contas e/ou de controle social do dinheiro público. Este acaba sendo tratado como propriedade privada, favorecendo o desperdício e desvio de recursos, como comprovam os escândalos de corrupção e de ineficiência no abastecimento de medicamentos no IMSS e na SSA ${ }^{27}$. Tais práticas não iniciaram nos anos de Salinas, de Zedillo ou de Fox, estes foram apenas os períodos para os quais ações latentes/escondidas tornaram-se públicas.

Cabe ressaltar aqui que este tipo de publicidade crítica em relação ao IMSS e a SSA só se evidencia a partir de meados da transição de regime, e de forma mais acentuada na democratização, com a saída do PRI da Presidência. Durante décadas o PRI promoveu, juntamente com a mídia, que também era controlada pelo partido, uma publicidade positiva extremada em relação às instituições públicas mexicanas. Como resultado, o IMSS ainda hoje é percebido, mesmo após a publicidade das corrupções, como instituição modelo não apenas do funcionalismo público-estatal, como de atenção médica à saúde ${ }^{28}$. De forma que para o mexicano de classe média, sobretudo o assalariado, o cuidar da saúde tem como modelo exemplar a prática curativa de saúde socializada ao longo de décadas nas instituições do IMSS.

No decorrer dos anos, as mudanças na seguridade social se davam em decorrência das reivindicações do movimento trabalhista, enquanto o surgimento de novos programas ou extensão da rede hospitalar do sub-setor da SSA ocorriam em resposta ao incremento populacional e ao surgimento de reivindicações e/ou de potencialidade de manifestações por parte da sociedade civil (Quadro 2.2). Estas mudanças se deram de forma paulatina e foram viabilizadas pelo modo como a matriz Estado-cêntrica mexicana administrava os recursos da economia, lançando mão do endividamento, interno e externo, sem resolver o problema fiscal

\footnotetext{
${ }^{27}$ Ver números de La Jornarda desde o período de Salinas.

${ }^{28}$ Este fato ficou claro nas entrevistas realizadas.
} 
tributário. Em reação às situações de crise (ou de risco de crise), a coalizão no poder lançava mão das instituições de assistência a saúde a fim de afastar a possibilidade (ou risco) de manifestação social ao processo de dominação vigente.

As políticas de públicas de saúde revelam-se, assim, como instrumento político do processo de legitimação do PRI no poder. Sua natureza pública-estatal e seu escopo dual de integração social foram determinados pela forma como se deu o relacionamento Estado/Sociedade, isto é devem-se: ao favorecimento de um grupo alvo, à integração corporativa de médicos e burocratas, à centralização da decisão/implementação e do financiamento; e ao fato de possibilitar tanto a realização de formas patrimonialistas de socialização (não prestação de contas, desvio de verbas e ineficiência de serviços), quanto a produção de efeitos sociais perversos: morte de crianças e recém nascidos e alta incidência de morbidades.

\section{Autoritarismo militar e política pública de saúde para a população aberta do Brasil}

No Brasil as políticas públicas de saúde originaram-se nos anos 1920/30²9 praticamente. No entanto, foram as políticas adotadas pela elite civil-militar, após a inauguração da "situação

\footnotetext{
${ }^{29}$ No Brasil, as primeiras iniciativas de seguro social não surgiram sobre o controle do Estado, mas como resposta direta das elites que se adaptavam às pressões gerais de uma classe trabalhadora emergente. Elas ocorreram na década de 1920, no período da República Velha ou Oligárquica, quando a elite governante assumiu a responsabilidade de definir um modelo particular de seguro social: as Caixas de Aposentadorias e Pensões (CAPs). Estas funcionavam como entidades autônomas semipúblicas, sob a supervisão do governo. Além disso, em meados da década de vinte surgiu no estado de São Paulo um sistema de saúde pública descentralizado, ajustado às questões sanitárias próprias de cada região do estado. Neste sistema, criado pelo higienista Geraldo de Paulo Souza, os centros de saúde atendiam e orientavam os enfermos, além de funcionar também como porta de entrada para o internamento hospitalar (Bertolli Filho, 2001). Isto ocorreu em São Paulo devido à existência da Faculdade de Medicina e à criação de institutos ou laboratórios de pesquisa médico-epidemiológicas desde o início da República, como o Butantã, o Biológico e o Bacteriológico (atual Adolf Lutz).

As CAPs só foram transferidas para as elites burocrática, mais especificamente para o Ministério do Trabalho, na década de 1930, quando foram unificadas e absorvidas pelos Institutos de Aposentadorias e Pensões (IAPs) (Cohn, 1996) (Malloy, 1886). “A criação dos IAPs representou não só uma resposta de demandas políticas das classes assalariadas (...), mas também respondeu a interesses econômicos bastante claros: a previdência social como instrumento de captação de poupança forçada” (Cohn, 1980, p.95). Em 1930, Vargas criou o Ministério de Educação e Saúde, o qual pretendia garantir o controle dos serviços sanitários do país. No que se refere à experiência descentralizadora em São Paulo, as reformas varguistas decretaram o fim desse sistema. Tanto em São Paulo, quanto nos demais estados do país, “os interventores sanitários optaram pela organização centralizada de serviços". Os atendimentos "foram orientados para o tratamento de enfermidades específicas, como o tracoma, a lepra e a ancilostomose” (...) "Os médicos foram excluídos das decisões sanitárias, que passaram a ser tomadas por políticos e burocratas” (Bertolli Filho, 2001, p. 31 e 32). O Ministério da Saúde só se desvincularia do da Educação em 1953, no governo Dutra, no período da redemocratização (1945-1964).
} 
autoritária” (Linz, 1977) de 1964, que produziram modificações mais significativas na natureza e escopo do domínio público a ser herdado pelo Sistema Único de Saúde. Vejamos então quais as principais características da MEC autoritária brasileira no pós 1964. Pretendemos ressaltar, mais especificamente, as bases político-sociais substantivas e objetivas que legitimam o poder instaurado, bem como a forma como atores sociais/econômicos privilegiados na relação com o Estado participavam da construção do domínio público-estatal na Saúde.

A organização política do novo regime autoritário brasileiro apresentou características singulares em relação ao México. Não tivemos no Brasil um regime revolucionário de longa duração, e marcado por uma relativa estabilidade da aliança política orquestrada por um único partido. No caso brasileiro, o Golpe de 1964 traduziu-se num "movimento político" que principiou um regime militar apresentado, desde o início, como excepcional e como um momento de refluxo necessário para fortalecer a democracia futura (Rouquié, 1988). A primeira diferença em relação ao México encontra-se no próprio símbolo/valor utilizado pela aliança golpista para legitimar a inauguração de uma nova ordem política. O que legitima substantivamente o autoritarismo brasileiro não é uma revolução social, mas a esperança de desenvolvimento controlado da democracia. Esta será constantemente reiterada, sobretudo nos períodos de crise e de mudança de governo, a fim de garantir a legitimidade do poder instaurado.

Esse regime de caráter transitório resultou do impasse entre o esgotamento da política nacional-populista (que orientou o desenvolvimento e a industrialização do país no pós-guerra) e os imperativos dos novos moldes de expansão capitalista, num período em que a elite brasileira era compelida a uma associação mais estreita com o capital monopolista internacional. Também foi uma reação da classe militar e das classes dominantes ao processo de democratização em curso desde 1945, e mais especificamente, uma reação civil-militar ao crescimento dos movimentos sociais e à conseqüente paralisia de decisões, que se traduziu na incapacidade, ou melhor, na dificuldade do sistema político vigente em atender as crescentes demandas sociais.

Nesta situação autoritária, como definida por Juan Linz, verificou-se uma relação singular entre regras autoritárias e instrumentos tipicamente democráticos. De um lado, foram concentrados os poderes da União no Executivo Federal. De outro, no entanto, institui-se um sistema bipartidário, com a criação da Aliança Renovadora Nacional (Arena), que dava sustentação ao Governo, e do Movimento Democrático Brasileiro (MDB), a oposição 
permitida. Esta contradição inerente à situação autoritária brasileira explica porque o Poder Central esteve sempre, a cada governo, efetuando mudanças político-eleitorais especificas, como alteração do calendário eleitoral e das regras das eleições, diferenciando as cidades e os estados cujos executivos/representantes serão eleitos direta ou indiretamente.

Politicamente, isto implica no uso arbitrário das instituições democráticas - a eleição e suas regras - e na usurpação do sentido da democracia. Esta é vista como instrumento para limitar o acesso ao poder e restringir a ação da classe política, seja no nível federal, seja no plano regional. Nesta situação, a arbitrariedade será uma constante das relações políticas, traduzindo-se em conchavos, negociações, e formas patrimonialistas de intermediação no poder.

Manteve-se também um Estado de cunho desenvolvimentista ${ }^{30}$, cujas estruturas e ações, de modo semelhante, mas distinto do Estado mexicano, refletem os interesses dos grupos em aliança com o poder. Na coalizão brasileira encontravam-se a tecnoburocracia civil e militar que controla diretamente o aparelho do Estado - a burguesia e as empresas multinacionais. Formava-se o modelo do tripé, em que os trabalhadores (e seus sindicatos), os estudantes, os intelectuais, as esquerdas e a população em geral eram mantidos à margem do sistema de poder. Como no México, é o desenvolvimento econômico que mantém unida a coalizão vigente e, assim, funda objetivamente a legitimidade do poder. No Brasil, no entanto, trabalhadores e sindicatos não fazem mais parte da aliança estatal no pós 1964.

A ascensão desta “coalizão internacional modernizadora” como classe dominante implicou no fim da antiga coalizão populista-democrática, configurando-se, assim, um tempo de oportunidade política para a realização dos interesses econômicos desse grupo. Ao conter as demandas que a democracia populista não podia ignorar, a coerção social derivada do regime militar propiciou mudanças 1) no sistema político, 2) na estrutura econômica, pela implementação das reformas que pretendiam acelerar a taxa de crescimento econômico interrompida no período 1962/1963 e 3) nas políticas sociais.

\footnotetext{
30 Trata-se de um padrão de autoridade que não é rompido com o movimento político de 1964, e que vem se modificando desde 1930: mediante a inserção de novos grupos ou atores à tríplice aliança estatal e por intermédio de modificações no regime político.
} 
Houve um amplo redesenho do financiamento da economia, no intuito de aumentar a captação de recursos financeiros para o setor público e orientar o sistema tributário (Saddi, 1999). O acesso do empresariado à atividade econômica se dava a partir de benefícios políticos concedidos pelo Estado, e não com base em regras de mercado. Com a reforma bancária, tributária e administrativa, que resultaram, por exemplo, na criação de canais de financiamento para determinados setores, a política propiciou um desenvolvimento econômico ainda não visto na História do país, conhecido como o milagre econômico. Este, contudo, ocorreu de forma politicamente significativa: sem que a maioria da população participasse da distribuição da renda nacional.

No período em que o Brasil crescia a taxas de $10 \%$ ao ano, a política limitou acentuadamente o acesso da população a políticas sociais mais universais. Nos primeiros anos do governo, e, sobretudo, nos anos da linha dura, a população deixou de ter acesso a várias das políticas sociais criadas no período democrático, como as políticas sanitárias do Ministério da Saúde. Como ressalta Vianna, "mantida a aparência constitucional, a política social transformou-se, através de imensas máquinas burocráticas que a operavam, dos cargos disponíveis e dos serviços prestáveis, no reino da política clientelista, eleitoreira e fisiológica” (Vianna, p.136). Vejamos então de que forma esta nova conformação do poder modificou o significado de público na atenção à saúde do brasileiro.

\subsection{A construção de um sistema público-estatal dual de saúde no Brasil}

Como resultado deste padrão estado-cêntrico de intervenção, a elite civil-militar ${ }^{31}$ brasileira rompeu com a prática coorporativa dos múltiplos fundos de saúde e com os esquemas associativos existentes desde 1930, centralizando as diversas burocracias previdenciárias ${ }^{32}$ em um único Instituto: o Instituto Nacional de Previdência Social - INPS. É por meio deste que o

\footnotetext{
${ }^{31}$ Foi centralizado em 1966, por meio de um Decreto Lei editado pelo Executivo

32 Os Institutos de Aposentadorias e Pensões existentes desde 1920, bem como seus serviços médicos são reunidos no INPS. Trata-se dos Institutos dos bancários, dos Comerciários, dos Empregados de Transportes e Cargas, dos Ferroviários e empregados em serviços públicos, dos Industriários e marítimos. O INPS também passou a incorporar os trabalhadores rurais (Funrural, 1971), empregadas domésticas (1972) e autônomos (1973), implicando em restrita expansão do acesso público ao cuidar curativo. O Público ligado ao Funrural, apesar de incorporado ao INPS, tinha uma organização e benefício médico diferenciados, pois não se tratava de previdência, mas de fundo. O Funrural foi criado pelo governo militar em 1971 devido ao percentual do campesinato na população brasileira (42\%). No posto do campo realizava-se apenas o atendimento de socorro, encaminhando a pessoa para o hospital geral da capital ou centro de referência mais próximo.
} 
público trabalhador formal passou a ter acesso a serviços médicos curativos após 1966. Entre assegurados e dependentes, 36 milhões de brasileiros (38\% da população) integravam o sistema do INPS em 1971, podendo se beneficiar de seus serviços médicos. O acesso da população mais pobre e sem vínculo formal de trabalho (40 milhões de brasileiros), correspondente a $42 \%$ da população do país, restringia-se a serviços proporcionados por governos estaduais, por prefeituras ${ }^{33}$ e por dependências 'para indigentes' das entidades médicas privadas sem fim lucrativo. Tratava-se de serviços dirigidos a pessoas destituídas de qualquer direito, e orientados pela política local ou estadual de tipo clientelista. Além de serem poucos, precários, e centralizados nas grandes cidades, tais serviços inexistiam nos pequenos distritos e vilarejos, resididos por $29 \%$ da população. Já a população de renda alta e média alta encontrava-se integrada ao sistema de saúde via mercado, isto é, mediante a compra dos serviços do setor médico privado lucrativo (Tabela 1.3).

Tabela 1.3 - População com acesso a serviços de saúde em 1972, Brasil

\begin{tabular}{|c|c|c|}
\hline Instituições & $\begin{array}{c}\text { População alvo, segundo renda ou } \\
\text { ocupação, número aproximado }\end{array}$ & $\begin{array}{l}\text { \% aproximada da } \\
\text { população }\end{array}$ \\
\hline \multicolumn{3}{|l|}{ Dados sobre acesso formal } \\
\hline Serviço privado lucrativo & $\begin{array}{r}\text { População de renda média e alta, } 20 \% \text { da } \\
\text { população que ficava com } 65 \% \text { da renda } \\
\text { do país. }\end{array}$ & $20 \%$ \\
\hline $\begin{array}{l}\text { Sistema previdenciário nacional - INPS - } \\
\text { Instituto Nacional de Previdência Social }\end{array}$ & $\begin{array}{l}\text { Trabalhador formal: } 36 \text { milhões de } \\
\text { assegurados e dependentes em } 1971 \text {. }\end{array}$ & $38 \%$ \\
\hline $\begin{array}{l}\text { Sistema público para população aberta - } \\
\text { Serviços estaduais, poucos municipais e } \\
\text { alguns serviços do setor privado filantrópico } \\
\text { (cobertura formal) }\end{array}$ & $\begin{array}{r}\text { Em tese toda a população pobre e não } \\
\text { assegurada: } 40 \% \text { dos brasileiros que } \\
\text { ficavam com apenas } 10,01 \% \text { da renda do } \\
\text { país. }\end{array}$ & $42 \%$ \\
\hline \multicolumn{3}{|c|}{ Hipóteses sobre o acesso real da população não-assegurada e de baixa renda } \\
\hline $\begin{array}{l}\text { População não-assegurada e de baixa renda } \\
\text { com algum tipo de cobertura de saúde }\end{array}$ & $\begin{array}{r}\text { População pobre residente em cidades } \\
\text { com mais de } 20.000 \text { habitantes }\end{array}$ & $13 \%$ \\
\hline $\begin{array}{l}\text { População não-assegurada e de baixa renda } \\
\text { com difícil ou nenhum acesso a serviços } \\
\text { públicos de saúde }\end{array}$ & $\begin{array}{r}\text { Residentes dos } 4.093 \text { distritos com menos } \\
\text { de } 20.000 \text { habitantes, residentes nos } 3.661 \\
\text { vilarejos com menos de } 2.000 \text { habitantes. } \\
\text { + população sem acesso nas capitais }\end{array}$ & $27 \%+2 \%=29 \%$ \\
\hline $\begin{array}{l}\text { Hipótese } 1 \text { = População não-assegurada e de } \\
\text { renda baixa com acesso real ao sistema } \\
\text { público de saúde }\end{array}$ & & $\begin{array}{r}13 \%+7,25 \%(\text { cerca } \\
\text { de } 1 / 4 \text { dos } 29 \%)= \\
\mathbf{2 0 . 2 5 \%}\end{array}$ \\
\hline $\begin{array}{l}\text { Hipótese } 2 \text { = População aberta e de baixa } \\
\text { renda sem acesso real ao sistema público de } \\
\text { saúde }\end{array}$ & & $\begin{array}{r}3 / 4 \operatorname{dos} 29 \%= \\
21,75 \%\end{array}$ \\
\hline
\end{tabular}

\footnotetext{
${ }^{33}$ O papel dos municípios era prestar serviços de urgência. Na década de setenta já havia um cinturão de pobreza em torno da cidade e vazios de ocupação. Destaca-se o serviço de atendimento médico (SAMDU). Este só fazia emergência, remetendo a os casos de baixa, média e alta complexidade para os hospitais dos públicos da capital ou do centro de referencia mais próximo.
} 
Fontes: Dados de assegurados e população residente: IBGE, Brasil Século XX, 2003. Dados de distribuição de renda: Celso Furtado.

Os dados do IBGE nos permitem formular algumas hipóteses adicionais sobre o acesso da população não-assegurada e de baixa renda aos serviços públicos de saúde. Se levarmos em conta que $27 \%$ da população brasileira habitava em distritos com menos de 20.000 habitantes, e 2\% em vilarejos com menos de 2.000 habitantes em 1972, apresenta-se bem plausível a hipótese de que o acesso a serviços de saúde mostrava-se extremamente difícil para 29\% dos 40 milhões de brasileiros (42\% da população), considerados como formalmente cobertos pela atenção médica pública não-assegurada. Possivelmente, aproximadamente 22\% da população brasileira (e não 42\%) em 1972 possuía acesso real aos serviços públicos de saúde, direcionados para a população aberta.

Este padrão de acesso público ao cuidar da saúde resultou de decisões políticas autoritárias, elaboradas a partir da própria esfera política, visando ao favorecimento dos atores em aliança com o poder: tecnoburocracia, indústria de saúde (nacional e internacional), serviços privados de saúde. Esta interação política seletiva entre Estado e sociedade pode ser verificada: 1) na forma como a política passou a distribuir o gasto na saúde, em detrimento da prática médica preventiva realizada pelo Ministério da Saúde, e 2) no modo como o setor industrial e de serviços médicos privados passaram a participar da atenção médica pública na administração pública-estatl INAMPSiana. Contudo, de forma distinta do autoritarismo pósrevolucionário mexicano, a situação autoritária brasileira promoveu um sucateamento exacerbado das atividades sanitárias do Ministério da Saúde, bem como utilizou a seguridade social para promover o crescimento dos serviços médicos privados no país. De forma que teremos um sistema público previdenciário de mix estatal privado.

Em 1971 apenas 5\% do gasto nacional com saúde foi destinado ao Ministério da Saúde, isto é, para o público não-previdenciário. Apesar dos estados brasileiros terem alocado 32\% de seus recursos na Saúde, a participação de São Paulo foi de $71,8 \%{ }^{34}$, superando de longe os

\footnotetext{
${ }^{34}$ As estruturas de saúde nos Estados eram caracterizadas por sua debilidade e inexistência em mais da metade das unidades administrativas do país. No entanto o Estado de São Paulo, sobretudo a capital, sempre se destacou no atendimento à saúde e nas práticas de saúde em relação aos demais da Federação, em virtude de seu caráter pioneiro na industrialização, e na conseqüente concentração da renda, do conhecimento e das práticas de intervenções públicas, sobretudo na capital. Para uma análise da origem das campanhas sanitárias em São Paulo, veja o livro de Hochman (1998), na bibliografia. Bahia e Rio de Janeiro, as duas antigas capitais do país, também tiveram um papel de destaque nas campanhas médicas, veja livro de Madel Luz (1982).
} 
demais estados. O INPS foi responsável por $41 \%$ do gasto nacional do setor, enquanto o setor privado despendeu apenas 8\% do total nacional naquele mesmo ano (Soares, 1976). Esta situação modificou-se em 1975, quando, de acordo com Donnangelo, 90\% dos gastos de todos os serviços médicos prestados no país mostravam-se direta ou indiretamente dependentes do INPS.

Isto ocorreu porque o cuidar público-estatal da saúde na previdência se traduziu em moeda de troca política com o empresariado, em aliança com o poder. Entre 1963 e 1975 tivemos o período áureo da compra de serviços de terceiros pelo INPS (Luz, 1979) (Cordeiro, 1984). O privado não participou do cuidar médico público-estatal previdenciário seguindo critérios de eficiência, próprios do mercado. A compra massiva de insumos e serviços médicos privados pelo INPS ocorreu de modo patrimonialista, em detrimento de uma racionalidade econômica na distribuição e gerenciamento dos recursos ${ }^{35}$.

A política de terceirização/privatização do domínio público-estatal previdenciário, adotada pela elite civil-militar, se deu por meio da contratação de clínicas e de hospitais particulares, visando ampliar a atenção médica no país sem que fosse necessário realizar investimentos estatais diretos no setor. No entanto, a política autoritária acabou promovendo uma reciclagem do dinheiro público, ao instituir fundos para financiar a proteção social (FGTS, FAZ, PIS/PASEP) ${ }^{36}$, os quais acabaram sendo desviados para outras finalidades. Este fato comprova, como tantos outros, a inexistência de uma racionalidade econômica nos planos e políticas desenvolvimentistas seguidas pelo regime militar.

Este processo de fomento estatal patrimonialista do setor privado, resultou na consolidação de um sistema de atenção à saúde centrado na atenção hospitalar: nas instituições INPSsiana e na rede privada contratada; filantrópica e privada lucrativa. Em 1968 o setor privado lucrativo detinha $43,45 \%$ dos hospitais no país, sendo $27,78 \%$ deles localizados nas capitais e, mais especificamente, nos estados da região Sudeste selecionados na tabela 1.4. Os filantrópicos, apesar de representarem 41,65\% dos hospitais do país, possuíam poucos hospitais

\footnotetext{
${ }^{35} \mathrm{O} \mathrm{BNH}$, e mais especificamente no que se refere à política habitacional, é um caso paradigmático deste tipo de prática.

${ }^{36}$ Veja as análises de Azevedo (1987) sobre o PIS/PASEP. Em relação ao FAZ, cabe mencionar que, em 1977, ano de alta arbitrariedade nas decisões comandas por Geisel, 79,5\% dos recursos do FAZ foram destinados para o setor privado. Também foram concedidos empréstimos ao setor privado, a juros irrelevantes, visava modernizar e incrementar a estrutura hospitalar no país. Veja Oliveira e Fleury Teixeira (1986), na bibliografia.
} 
na região Norte, e nenhum na cidade de Manaus. Os hospitais públicos, por sua vez, além de corresponderem a apenas $14,9 \%$ do total do país, se concentram nas capitais (46,05\%) e, mais especificamente, na antiga capital: Rio de Janeiro (Tabela 1.4).

Tabela 1.4 - Hospitais Públicos, Privados Lucrativos e Filantrópicos no Brasil, 1968

\begin{tabular}{|c|c|c|c|c|c|c|c|c|}
\hline & \multicolumn{2}{|c|}{ Total de Hospitais } & \multicolumn{2}{|c|}{$\begin{array}{l}\text { Hospitais Oficiais } \\
\text { (públicos) }\end{array}$} & \multicolumn{2}{|c|}{$\begin{array}{c}\text { Hospitais } \\
\text { Particulares } \\
\text { Lucrativos }\end{array}$} & \multicolumn{2}{|c|}{$\begin{array}{c}\text { Hospitais } \\
\text { Particulares } \\
\text { Filantrópicos }\end{array}$} \\
\hline & Número & $\%$ & Número & $\%$ & Número & $\%$ & Número & $\%$ \\
\hline Brasil & 3.397 & 100,00 & 506 & 14,90 & 1.476 & 43,45 & 1.415 & 41,65 \\
\hline Capitais & 811 & 23,87 & 233 & 46,05 & 410 & 27,78 & 168 & 11,87 \\
\hline \multicolumn{9}{|l|}{ Estados selecionados } \\
\hline Estado de São Paulo & 651 & 19,16 & 42 & 8,30 & 257 & 17,41 & 352 & 24,88 \\
\hline Estado de Minas Gerais & 460 & 13,54 & 44 & 8,70 & 170 & 11,52 & 246 & 17,39 \\
\hline Estado do Paraná & 382 & 11,25 & 27 & 5,34 & 290 & 19,65 & 65 & 4,59 \\
\hline \multicolumn{9}{|l|}{ Capitais selecionadas } \\
\hline Manaus & 10 & 0,29 & 7 & 1,38 & 3 & 0,20 & 0 & \\
\hline Boa Vista & 3 & 0,09 & 1 & 0,20 & 0 & & 2 & 0,14 \\
\hline Recife & 44 & 1,30 & 18 & 3,56 & 19 & 1,29 & 7 & 0,49 \\
\hline Goiânia & 41 & 1,21 & 7 & 1,38 & 32 & 2,17 & 2 & 0,14 \\
\hline Cidade de São Paulo & 141 & 4,15 & 14 & 2,77 & 87 & 5,89 & 40 & 2,83 \\
\hline Guanabara (Rio de Janeiro) & 198 & 5,83 & 65 & 12,85 & 92 & 6,23 & 41 & 2,90 \\
\hline Curitiba & 33 & 0,97 & 7 & 1,38 & 20 & 1,36 & 6 & 0,42 \\
\hline
\end{tabular}

Fonte: IBGE, Estatísticas Século XX

Com efeito, os prontos socorros se encontravam em minoria no Brasil, existindo apenas 448 deles, em um país com mais de 90 milhões de habitantes e de tamanho continental. O Hospital, assim como no caso mexicano, consolidou-se como símbolo do atendimento públicoestatal no país. A distribuição regional dos prontos socorros não se mostrava distinta da do complexo hospitalar hegemônico: concentrava-se nas capitais, sendo São Paulo a capital com o maior número de prontos socorros no país (Tabela 1.5).

Tabela 1.5 - Prontos Socorros e Hospitais no Brasil, 1968

\begin{tabular}{lcrrr}
\hline & $\begin{array}{c}\text { Total de Prontos } \\
\text { Socorros }\end{array}$ & Total de Hospitais & $\begin{array}{c}\text { \% Prontos } \\
\text { Socorros }\end{array}$ & \% Hospitais \\
\hline Total Brasil & 448 & 3.397 & $100 \%$ & $100 \%$ \\
Total Capitais Brasil & 151 & 811 & $33,70 \%$ & $23,87 \%$ \\
Capitais selecionadas & & & & \\
Manaus & 1 & 10 & 0,22 & 0,29 \\
Macapá & 0 & 4 & 0,00 & 0,12 \\
Teresina & 2 & 9 & 0,45 & 0,26 \\
Salvador & 6 & 29 & 1,34 & 0,85 \\
Recife & 2 & 44 & 0,45 & 1,30 \\
Goiânia & 2 & 41 & 0,45 & 1,21 \\
\hline
\end{tabular}




\begin{tabular}{lrrrr}
\hline Cidade de São Paulo & 61 & 141 & 13,62 & 4,15 \\
Guanabara (Rio de Janeiro) & 28 & 198 & 6,25 & 5,83 \\
Curitiba & 3 & 33 & 0,67 & 0,97 \\
Porto Alegre & 9 & 33 & 2,01 & 0,97 \\
\hline
\end{tabular}

Fonte: IBGE, Estatísticas Século XX, 2003.

A indústria da saúde, de forma semelhante ao México e aos demais países em desenvolvimento, cresceu acentuadamente no período desenvolvimentista, com a implementação e consolidação da indústria de bens de consumo e de bens duráveis. A indústria farmacêutica participava ativamente do cuidar público-estatal da saúde, uma vez que o governo federal foi o responsável por mais de $50 \%$ das compras de medicamentos do setor no país, e o INPS um dos maiores consumidores. Este setor mostrava-se em franco crescimento desde os anos 1960, sendo que 97\% das empresas já eram controladas por grupos estrangeiros (Soares, 1977).

De forma que na periferia brasileira, assim como na mexicana, o Estado também se constituiu em lugar privilegiado para a extensão da empresa privada, e mais especificamente da indústria da saúde, havendo a difusão da prática médica hospitalar de tipo curativo, baseada na produção de consultas, receitas, exames e hospitalizações. Assim como no mundo desenvolvido, Panacéia ficou mais autônoma em relação à Higéia, no entanto, conquistou uma independência socialmente precoce, embora politicamente significativa. No caso da periferia latino-americana, a panacéia realizada impôs-se e articulou-se com o Estado, apresentando-se literalmente como a única solução de todos os males. Observe, por exemplo, que o tratamento hospitalar para Tuberculose não era mais recomendado nos anos 70 (Gentile de Mello, 1977). No Brasil, contudo, 70\% dos recursos humanos e financeiros no tratamento da Tuberculose ainda eram destinados a sanatórios e clínicas, os quais cuidavam de apenas 10\% dos tuberculosos do país (Gentile de Mello, 1977) (Soares, 1977).

A política autoritária não apenas produziu o desenvolvimento acelerado e socialmente antagônico do cuidar curativo, em detrimento da prática preventiva e de primeiro nível da atenção médica, como possibilitou a realização de práticas administrativas com efeitos políticos e sociais perversos em relação ao cuidar da saúde da população: sub-atendimento, corrupção, fraude de guias de internação e evasão do público trabalhador organizado para a medicina de grupo em crescimento. 
Como a capacidade de atendimento do sistema mostrava-se insuficiente para atender os assegurados do INPS e seus dependentes, a população foi submetida a filas quilométricas de atendimento. Verificou-se também um sub-atendimento generalizado com conseqüências sociais perversas na rede pública. Em 1974, por exemplo, 50 mil pessoas morreram devido a infecções contraídas nos hospitais durante a internação (Soares, 1977, p.43).

A corrupção também consistia numa prática constante na administração pública-estatal da rede INPSiana, e tinha como protagonista o funcionário público e setor médico privado conveniado com o sub-setor público-estatal. Em Porto Alegre, hospitais particulares conveniados mantinham pessoas saudáveis internadas durante meses a fim de receber os pagamentos devidos pelo INPS. Com esta prática, o setor médico privado "lucrava a diferença entre a taxa fixada e os gastos minimizados pela inexistência de tratamento” (Soares, 1977, p.43). Além disso, 60\% das cesarianas realizadas no sistema ocorriam sem nenhuma necessidade (Gentile de Mello, 1977). De forma que as guias de internação eram corriqueiramente falsificadas, sem que houvesse um controle por parte da burocracia INPSiana.

O crescimento do setor médico privado lucrativo, de um lado, e a crise do sistema INPsiano do outro, possibilitou o abandono dos serviços médicos da Seguridade Social por parte do público trabalhador, com destaque para o público sindical. Este, diferentemente do caso do México, passou a efetuar convênios com o setor privado de saúde. A Wolkswagen, juntamente com o sindicato da categoria, por exemplo, tiveram um papel pioneiro na adesão à medicina de grupo, também originada no período.

Tais práticas de socialização INPSianas no cuidar da saúde revelam a situação latente de crise estrutural do próprio sistema, de forma semelhante à socialização mexicana no IMSS e na SSA. No caso brasileiro, entretanto, estes efeitos perversos já se tornaram públicos durante o próprio regime autoritário; com as filas quilométricas e os escândalos de corrupção divulgados em jornais (depois com algumas censuras é claro). O INPS (e futuro INAMPS) não é tido pelo brasileiro como instituição modelo de atenção médica. Este modelo é/será publicamente atribuído ao setor privado médico, obra da publicidade e atuação crescente deste próprio setor, em anuência com a esfera política e a mídia, mas em contraposição a uma divulgação positiva do significado de público-estatal na saúde. 
Ao se dar prioridade para a medicina curativa lucrativa e não para a preventiva e assistencial para a população mais pobre, a política autoritária realizou uma interrupção drástica das atividades preventivas desenvolvidas pelo Ministério da Saúde no período democrático, sobretudo nos anos de João Goulart. A queda no orçamento do Ministério da Saúde gerou um descontrole epidemiológico no país, chamado pela literatura como 'epidemias silenciosas'. Nos dois primeiros anos da epidemia de meningite, que se alastrou pela periferia urbana no país desde 1971, os médicos ligados ao governo desmentiam constantemente a notícia sobre a disseminação da doença (Bertolli Filho, 2001). Ainda havia no país (desde 1872) epidemias de peste bubônica, sobretudo na Bahia, Ceará e Pernambuco. Ademais, 5\% das mortes na região amazônica deviam-se às condições desfavoráveis de higiene, saneamento e desnutrição, e da conseqüente propagação de doenças. A malária ainda não havia sido interrompida e a mortalidade infantil era uma das mais altas do mundo ${ }^{37}$. Isto significa que Brasil, assim como o México, era conhecido como um país de doentes pela comunidade internacional.

A política autoritária passou não apenas a conter, como também a reprimir, a atuação da Medicina Preventiva ou Social. Os canais de participação política na saúde, como as Conferências Nacionais de $\mathrm{Saúde}^{38}$, foram esvaziados de seu conteúdo crítico. A $3^{\mathrm{a}}$ Conferência Nacional de Saúde, ocorrida antes do golpe civil-militar, foi um marco na História da saúde pública brasileira, dada a ampla participação de segmentos políticos e sociais, bem como às temáticas discutidas: municipalização, descentralização, e universalização da assistência a saúde. Os atores deste movimento, em especial os sanitaristas, já possuíam uma visão social e não meramente epidemiológica da Medicina Preventiva, de forma política e socialmente diferenciada do similar mexicano. Para a maioria destes atores, o cuidar público da saúde não se traduzia em mera tarefa burocrática corporativa, mas em missão de vida. Em entrevista ao Pasquim, Sérgio Arouca relata-nos como a Medicina Preventiva, que se transforma tempos depois na Medicina Social brasileira, influenciou sua vida.

"Só encontrei um trabalho com papel social na Medicina Preventiva, que era uma área que estava começando no Brasil. A região de Ribeirão Preto naquela época era uma região com grande incidência de doença de Chagas ... E o problema todo se resumia a como os bóias-frias

\footnotetext{
${ }^{37}$ Veja livro de Soares (1977) na bibliografia, entre outros.

${ }^{38}$ Existem no país desde 1941.
} 
viviam, e o tipo de casa onde o barbeiro entrava ... Aqui sim comecei a ter um trabalho de ação política. Estava discutindo a questão da vida das pessoas do campo, a questão da reforma agrária e fazendo também minha ação profissional, trabalhando com doença de Chagas ... Isto foi por volta de 1963 ... A Medicina Preventiva foi o movimento em que me envolvi profundamente e que marcou a minha vida. Quando comecei a estudar distribuição de doenças, causa das doenças e como enfrentar isto, não do ponto de vista individual, mas coletivo ... comecei a me perguntar sobre um instrumento teórico para repensar a sociedade. Eu tenho que começar a discutir as determinações sociais. Não me basta estar discutindo que o bacilo de Koch provoca a Tuberculose. Tenho que começar a estudar as ciências sociais. Começamos um confronto na área da saúde de toda esta questão da interpretação da realidade. Aí se deu essa idéia de criar um campo no Brasil que supera a Medicina Preventiva e que se transforma em Medicina Social” (Ziraldo et al., 2003).

Em meados dos anos 70 esta missão de vida se confundiu com a própria mobilização pela democracia, convertendo-se em ação política apaixonada ${ }^{39}$ pela criação de um domínio público mais universal, descentralizado e integral no cuidar da saúde do brasileiro. Esta atuação se deu, em distintas proporções e de forma ainda incipiente, tanto na esfera social, quanto na esfera política, como veremos no capítulo seguinte.

Trata-se de um movimento que, nos anos do regime militar, tão-somente teve sua atuação interrompida na esfera política (onde prevaleciam os interesses da esfera privada capitalista), mas cuja continuidade manteve-se por meio da reprodução de novas formas de mobilização: responsáveis pela formação e cooptação de uma nova geração de sanitaristas, bem como pela renovação do pensamento/prática da medicina preventiva brasileira.

Este grupo não se encontrava controlado corporativamente pelo Estado no regime autoritário, como ocorria na política priista mexicana, mas permanecia com uma atuação política autônoma, no Partido Comunista Brasileiro e em outros segmentos de esquerda. Também encontraram médicos não afiliados a partidos ou grupos de esquerda, mas envolvidos com a causa sanitarista social e, portanto, adeptos do movimento, como Sebastião Moraes em Campinas.

\footnotetext{
${ }^{39}$ O processo político do SUS revelará se esta atuação apaixonada, ao ser confrontada com outras formas de atuações e com a realidade política e social do país, mostrou-se de fato recíproca às necessidades do momento e suficientes para a realização de um sistema integral e universal de atenção à saúde na periferia do capitalismo.
} 
No início dos anos 70 a atuação do movimento sanitário se deu de forma significativa no meio acadêmico com a formação dos Departamentos de Medicina Preventiva pelo país, como ocorreu em outros países da América Latina. Nestes novos cursos, formou-se uma nova geração de médicos comprometidos com a causa social na saúde, os quais, juntamente com a velha guarda, estarão à frente do movimento pela saúde nos anos seguintes, como veremos. Ademais, a estrutura INPSiana ainda abrigava na sua estrutural central, diferentemente do México, alguns dos burocratas/sanitaristas críticos em relação às condições públicas de saúde brasileira, dentre os quais destacava-se Carlos Gentile de Mello. Estas contradições devem-se ao fato das relações Estado/Sociedade, no Brasil, terem sido caracterizadas não apenas por formas de representação democráticas, mas também por formas de intermediação política autoritária dos interesses inseridos na esfera estatal (Schwartzman, 1982).

\section{Conclusão}

Há que se reconhecer que as reformas públicas de saúde, tal como legalizadas nos anos 80, e em implementação a partir de então, sobretudo, ocorreram em sociedades cujas políticas públicas têm sido determinadas por padrões autoritários de poder, em economias periféricas aos centros hegemônicos do capitalismo, e onde o desenvolvimento econômico não ocorreu concomitantemente com a conquista de uma democracia política e social. Embora de forma distinta, tanto no Brasil, como no México, os novos domínios públicos-estatais de saúde carregarão (e ainda trazem consigo) interesses cristalizados ao longo de décadas, bem como formas de socialização institucionalizadas e legitimadas nos respectivos domínios públicoestatais, os quais dificultarão e/ou imprimirão ritmos diversos, mas lentos, aos processos de implementação dos novos valores e diretrizes de políticas públicas construídos a partir dos anos 80 sobretudo.

No Brasil, tendo em vista a privatização precoce do sistema em relação ao México, os representantes do setor médico privado de saúde serão os grandes opositores às mudanças no domínio público na saúde. No México, como vimos, a participação privada ainda se limitava mormente ao fornecimento de insumos e medicamentos. De acordo com cálculos de Victor Soria (1999), em 1970 o gasto do setor privado com saúde compreendia apenas 0,86\% em relação ao total nacional, e no final da década, embora tendo dobrado, este número ainda era de 1,50\%. Outros atores, por participarem de forma específica da realização do cuidar público da 
saúde em cada país, também terão um peso e atuação distinta ao longo do processo de reforma vindouro. Referimos-nos mais especificamente aos sanitaristas da SSA e do Brasil, à classe trabalhadora sindical, aos burocratas/funcionários do IMSS e INPS e, certamente, aos novos atores que emergirão ou terão suas posições revalorizadas no decorrer dos distintos processos de transição: sociedade civil, organizações de saúde e atores políticos dos governos nacionais e sub-nacionais.

Tanto no autoritarismo brasileiro quanto no mexicano a política pública de saúde não foi construída como direito social, nem como direito individual democrático. Estados de matrizes-cêntricas não lograram produzir politicamente a democratização da assistência e do cuidar curativo. Produziram, no entanto, uma versão segmentada e socialmente perversa da atenção médica pública, orientada não apenas pela prática médica curativa, já hegemônica no mundo capitalista, como por formas patrimonialistas de organização e socialização na administração pública. Em sua vertente latino-americana, e mais especificamente, brasileira e mexicana, o autoritarismo da política implicou na negação do acesso ao cuidado médico curativo - seja na seguridade social, seja no setor privado - a aproximadamente um terço da população. De forma que a democratização na saúde apresentava-se, nos dois países, como o primeiro grande desafio das reformas a serem iniciadas na década de 1970.

Entretanto, o caráter pós-revolucionário da política mexicana, diferentemente da natureza militar do autoritarismo brasileiro, atuou de forma um pouco menos perversa em favor da população não-assegurada, apesar da baixa capacidade de assistência médica (no sub-setor da SSA) e da ausência de um pensamento de saúde pública crítico na SSA. Não houve no México um processo de precarização e interrupção de grande parte da ação preventiva a saúde, como ocorreu no MS brasileiro durante o regime autoritário. Revela-se, portanto, politicamente significativo o fato de México possuir indicadores de morbidade e de mortalidade infantil, mesmo que ainda altamente negativos, pouco melhores que os brasileiros.

Contudo, foi o próprio caráter pós-revolucionário da política que legou ao país décadas de autoritarismo, visto que o poder recorrentemente utilizava-se do símbolo ideológico da Revolução a fim de se legitimar no poder. Paradoxalmente, esta legitimidade substantiva possibilitava - não unicamente, mas de modo privilegiado - a reprodução/permanência de um domínio público-estatal circunscrito a determinados setores da população, os quais iam sendo integrados na política e, assim, mantidos sob o controle do Estado. 
Já no Brasil, foi possível ao autoritarismo militar desconstruir, de um lado, o que já havia em termos de assistência e ações preventivas no Ministério da Saúde. De outro lado, no entanto, sempre lançou mão do símbolo da democracia a fim de se legitimar enquanto poder transitório para a democratização. Nesta, em sua fase pretérita, a saúde pública brasileira havia se renovado, incorporando o conhecimento da medicina social e politizado o Ministério da Saúde. A democracia populista brasileira não ocasionou o surgimento de direitos sociais na saúde, como na Inglaterra, mas possibilitou o princípio (ainda incipiente) de um novo processo de construção do público.

A partir de 1974, no Brasil, e de 1970, no México, iniciou-se um processo de extensão da cobertura na saúde para camadas mais pobres e de transferência da responsabilidade dos serviços para governos sub-nacionais nos respectivos domínios público-estatais de saúde. Novos programas de atenção à saúde foram destinados à população aberta, envolvendo formas díspares de desconcentração/descentralização. Brasil e México encontravam-se em meio a crises políticas e econômicas diversas, mas nos tempos iniciais de diferentes rotas de dupla transição política. Tratava-se também do tempo político de incorporação das recomendações de programas de atenção primária, da Organização Pan Americana de Saúde.

Cabe-nos agora investigar por que e em que termos a partir de 1974, no Brasil, e de 1970, no México, iniciou-se de fato uma nova construção do domínio público na saúde, voltada para a descentralização da atenção para a população aberta. Esta política é o objeto direto de estudo desta tese de doutoramento, cujas especificidades políticas (no Brasil e no México) serão analisadas a seguir. 


\section{Capítulo 2 - Crises Estado-cêntricas e participação política na redefinição da política pública: o processo inicial da reforma da política pública de saúde no México (1970-1983) e no Brasil (1974- 85).}

Nas décadas de 60 e 70 México e Brasil eram conhecidos não apenas pelo célere crescimento econômico que se dava paralelamente ao incremento da desigualdade social, mas também como países de doentes e com alta incidência de doenças e mortes na sociedade. De forma socialmente perversa, mas politicamente significativa, a política Estado-cêntrica do autoritarismo pós-revolucionário mexicano e da situação autoritária brasileira negaram o acesso à atenção à saúde a praticamente um terço da população, que se encontrava à margem do processo econômico. Tal acesso constituía privilégio dos setores trabalhistas organizados (sobretudo o urbano) e das classes mais ricas, respectivamente nas instituições médicas da seguridade social e no setor médico privado.

Neste capítulo lançaremos mão da análise do processo político de praticamente uma década, no México (1970-83) e no Brasil (1974-85), a fim de identificar o distinto modo como novos grupos/movimentos sociais participam do processo inicial de construção da reforma de saúde - direcionada para a população não assegurada. Procuraremos verificar em que termos padrões específicos de participação política na política pública - os quais serão interpretados como padrões de interações entre a esfera política e social -, foram responsáveis pela produção de mudanças singulares na natureza e escopo da política pública, bem como pela construção de domínios públicos-estatais com legitimidades políticas próprias. Investigaremos o tempo político concernente aos governos de Echeverría (1970-76) e de Portillo (1976-82), no México, e de Geisel (1974-79) e de Figueiredo (1979-85), no Brasil.

Politicamente, a década a ser estudada apresentou-se como tempo de oportunidade para se iniciar uma história social na saúde, com constrições e possibilidades políticas distintas em relação à ampliação/democratização na saúde. Nesta, a redefinição do domínio público da saúde relacionou-se à crise política das respectivas MECs, caracterizadas, em cada país, pelo acirramento do descompasso existente entre mudanças estruturais - que acirraram as contradições de desigualdades - e integração, ocasionando o surgimento de movimentos sociais/populares. Estes, no entanto, não apenas possuíram características distintas, como 
participaram de modo específico do processo da política pública. Conseqüentemente, as pressões sociais tiveram um peso político diferenciado na gênese do processo de redefinição do público na atenção à saúde. Ademais, surgiram atores políticos de distintas naturezas, os quais se posicionaram como protagonistas políticos neste período inicial de mudanças subjacentes a política de saúde.

Brasil deu início a uma rota de construção participativa, em que a redefinição do público foi primeiramente vivenciada na esfera social, por meio dos movimentos sociais de saúde, num contexto em que a universalização e a descentralização da saúde se confundiam com a luta pela democratização. Enquanto México deu início a uma construção nãoparticipativa na saúde, em que a redefinição do público na saúde efetuou-se $\underline{\text { sem a }}$ participação política direta de movimentos críticos de saúde e a partir da esfera de poder (Quadro 3.3) ${ }^{40}$, onde não apenas se encontravam representados os interesses cristalizados da MEC, mas também já prevaleciam - em meados do governo de Portillo - os interesses da nova elite priista neoliberal (já em formação/articulação no poder).

De forma semelhante, as redefinições das políticas públicas consistiram processos caracterizados pelas contradições existentes entre a necessidade de contenção da crise econômico fiscal do Estado, de um lado, e de manutenção dos símbolos e valores que legitimavam o poder perante a sociedade em geral, de outro. No entanto, em cada país o processo de decisão/elaboração resultou de distintos modos de participação na política. Nosso primeiro argumento é que o escopo mais estreito da política pública mexicana, em contraste com a proposta radical de mudança da reforma sanitária brasileira, já parcialmente incorporada na agenda política nos anos de Figueiredo, sobretudo, deveu-se não apenas à consolidação de um marco teórico amplo de Medicina Social no Brasil e à conseqüente crítica ao modelo privatista, excludente e corrupto do INAMPS, mas, também, à participação de representantes deste movimento: tanto na esfera social quanto na esfera política. Isto não se verifica no México, nem na esfera social (por meio da implementação de novas práticas de saúde junto à comunidade ou mediante movimentos sociais específicos de saúde), nem na esfera política da matriz estado-cêntrica mexicana.

As especificidades políticas da rota participativa e não-participativa na saúde (Quadro s3.2 e 3.2) serão evidenciadas não apenas na elaboração da política, como também nas

\footnotetext{
${ }^{40}$ Este se encontra no Capítulo 3.
} 
problemáticas concernentes à sua implementação e continuidade. Nosso argumento é que as decisões de políticas públicas realizadas na esfera política macro (nacional), resultantes de distintas modalidades de articulação entre interesses globais e interesses políticos nacionais, dificilmente têm sido executadas no decorrer do processo de implementação, gerando, assim, conflitos e problemáticas antagônicas à política intencionada. Este tipo de paradoxo das conseqüências, amplamente estudado pelas Ciências Sociais, assume uma configuração política mais conflituosa e socialmente mais contraditória desde os finais dos anos 70, em virtude da revalorização demasiada e politicamente significativa da economia.

Esta dupla dificuldade de execução da política pública, vinculada, de um lado, aos conflitos políticos e, de outro, ao baixo envolvimento da sociedade e à pouca/inexistente condição (institucional, material, informacional) de realização dos valores e diretrizes das estratégias produzidas na esfera política macro (nacional), traz à tona o descompasso existente entre intenção política macro e viabilidade de execução nas esferas políticas micro (nos municípios no Brasil e nos estados no México). Em distintos tempos, ritmos e formatos, tal assimetria tem acarretado constrições sócio-políticas acirradas e fracassos de políticas/programas, contribuindo para o reinício de um novo processo de identificação do problema e de redefinição da política pública, no nível macro. Nosso segundo argumento é que articulações distintas entre participação política e grupos/movimentos sociais, por corresponderem a padrões de mobilização social e de participação política direta em prol das necessidades de saúde da sociedade, bem como por desencadearem problemáticas concernentes à socialização e realização da política intencionada, são determinantes para a compreensão dos desafios e possibilidades presentes na construção de um novo domínio público na política de saúde.

Os dois argumentos do trabalho ressaltam, portanto, a existência de inter-relações politicamente significativas entre o processo de elaboração e o de implementação, entre a política macro e a política micro/prática micro, as quais serão interpretadas como padrões de legitimidade $^{41}$ da política pública, com probabilidades políticas distintas de realização e

\footnotetext{
41 O conceito de legitimidade compreende um conceito inter-relacional, isto é, subjacente ao padrão de relacionamento existente entre dominantes e dominados na esfera política da vida, o qual se encontra estreitamente relacionado ao de dominação. Podendo, assim, ser compreendido como probabilidade de obediência e reconhecimento do/ao domínio exercido por um poder que reivindica sua legitimidade perante a sociedade. $\mathrm{O}$ conceito de legitimidade, portanto, traz à tona problemas políticos aos quais todo o poder/estado enfrenta constantemente: a luta pela alocação de recursos escassos e a possibilidade de ter suas decisões obedecidas e
} 
continuidade/ruptura nos governos e/ou décadas seguintes. No caso de México e Brasil, os vínculos existentes entre padrões de participação direta na decisão e legitimidade da política pública mostram-se sócio-politicamente relevantes para se entender os sentidos das mudanças efetuadas no domínio público, no que se refere ao cuidar da saúde da população aberta. O foco concentra-se nas retro-alimentações existentes entre Sociedade e Estado. A base analítica para se pensar as contradições da mudança não se limita ao Estado, estende-se à Sociedade.

\section{Crises políticas, autoritarismo pós-revolucionário e solidariedade na saúde: não-participação direta e baixa viabilidade política, México (1970-1982)}

Foi a partir das situações de crises político-sociais e econômicas desencadeadas nos anos 70 e início dos 80, correspondentes aos sexênios de Echeverría (1970 a 1976) e de Portillo (1976 a 1982), que a política mexicana começou a efetuar mudanças no domínio público, no que se refere ao cuidar da saúde da população aberta. Tratava-se de sexênios excepcionais para a política mexicana, tendo em vista que os períodos de desenvolvimento econômico e/ou de normalidade econômica foram seguidos por períodos de instabilidade econômica e de incerteza política ainda não vivenciados desde a consolidação do partido de Estado. Neste contexto de crise, as relações entre o poder político e sua coalizão dominante passaram a ser marcadas por conflitos e tensões. Verificou-se assim o início de um processo de mudanças nas relações estatais, caracterizado pela incapacidade do Partido de Estado em produzir a costumeira estabilidade política e normalidade econômica lançando mão dos mecanismos estado-cêntricos. Estes, no entanto, continuarão caracterizando a política priista, apesar da mudança efetuada em sua coalizão política dominante ao final do governo de Portillo. O surgimento de novas políticas públicas de saúde ocorrerá sem que haja mudança significativa na estrutura/relações da MEC, em especial no que se refere ao fato do partido de Estado continuar a efetuar

julgadas (reconhecidas ou não) pela sociedade (Coicaud, 2002). Neste trabalho o conceito de legitimidade será utilizado como probabilidade de política na construção de novos comandos de obediência ou direitos de governo, e também como probabilidade de realização destes novos direitos, aqui exemplificados pela política de saúde para a população aberta. Esta probabilidade dependerá dos valores sócio-culturais e das práticas sociais e políticas consideradas como legítimas por uma sociedade, numa 'situação particular'. O objetivo é assinalar as direções/sentidos das mudanças que ocorrem na política de saúde. Assinalamos ainda que as problemáticas políticas concernentes à identidade social e à responsabilidade política, embora também relacionadas ao conceito de legitimação, não serão diretamente tratadas neste capítulo. Contudo nortearão as análises dos capítulos seguintes. 
mudanças nas políticas públicas a partir da esfera política tão-somente, controlando os movimentos sociais organizados (e dependentes da estrutura estatal).

\subsection{Os anos de Echeverría (1970 a 1976) - a origem política autoritário-conservadora dos programas solidários.}

A capacidade do Estado para administrar as contradições políticas latentes ou manifestas pelos grupos em aliança com o poder foi afetada pelo esgotamento do modelo econômico ${ }^{42}$. Neste contexto, os empresários passaram a reivindicar uma nova forma de relação com o sistema político. O enfrentamento entre a Presidência da República e grupos empresariais ocorreu entre 1974 e 1976, no sexênio de Echeverría, ocasionando a inserção do empresariado em algumas áreas do aparato estatal. Contraditoriamente, as políticas tradicionais de promoção do setor privado foram minando a própria autonomia do setor público, uma vez que elas intensificaram a participação privada na estratégia de crescimento econômico. Como resultado, a concentração econômica alcançada por este setor deu-lhes os instrumentos necessários para pressionar o poder em caso de divergência de interesses: queda no investimento e fuga de capitais ${ }^{43}$ (Basáñez, 1990).

Ademais, os questionamentos de outros grupos sociais, além dos trabalhadores inseridos na aliança com o Estado, começaram a ser cada vez mais evidentes deste o movimento estudantil de 1968. Este movimento detonou uma série de manifestações que se estenderam pelo o país até 1977. Como exemplos podemos citar: 1) outros movimentos estudantis na capital e em alguns estados; 2) movimentos de trabalhadores de sindicatos e empresas, reivindicando o aumento de salários em todo o país, culminando no surgimento do sindicalismo independente do Estado, 3) movimentos campesinos e de comunidades indígenas com ocupação de terras em vários estados (O movimento iniciado em Chiapas adquiriu relevância nacional), 4) mobilização entre os pobres (colonos) nas cidades mais populosas, 5)

\footnotetext{
${ }^{42}$ A situação de crise foi primeiramente evidenciada no final da década de 60, com o esgotamento do modelo de desenvolvimento estabilizador e, em seguida, nos anos setenta, pela crise gerada pelo então modelo de desenvolvimento compartido. O desenvolvimento compartido foi um manifesto político do presidente, em reação aos movimentos sociais, em que afirmava que a economia seria direcionada para fortalecer o Estado a fim de que ele pudesse criar políticas direcionadas para o setor popular. Mesmo levando-se em conta o período do boom do petróleo (1978 a 1981), o fato é que no decorrer dos anos 70 a intervenção política Estado-cêntrica na economia não logrou produzir de forma contínua os índices de estabilidade econômica usuais aos anos anteriores.

${ }^{43}$ Estas pressões se intensificaram nos períodos de crise econômica, em 1976 e em 1982, no início e fim de dos sexênios de Echeverría e de Portillo.
} 
tomada de governos municipais (insurgência municipal) e de palácios de governos estaduais em protesto a atos do Executivo ou às eleições, culminando na queda de governadores (Cansino, 2000).

Neste contexto, a extensão do acesso público à saúde mostrava-se politicamente significativa para a continuidade do PRI no poder nesta nova fase, uma vez que este se legitimava não apenas por sustentar o desenvolvimento da economia (perante sua coalizão), como também por utilizar-se recorrentemente do símbolo da Revolução Mexicana. Foi portanto em meio às situações de crise político-sociais que se originaram os programas solidários de atendimento a saúde. Estes novos programas foram adotados em reação aos movimentos desencadeados em escala nacional, desde o movimento estudantil de 1968. No entanto, não existiu uma ampla mobilização social na Saúde e, mais especificamente, um movimento de saúde que, além de crítico ao sistema vigente, tenha participado diretamente na elaboração da política pública. Esta continuava a ser elaborada pelo quadro diretivo da SSA, conhecidos como os velhos sanitaristas do PRI. Estes eram recrutados na própria Escola de Saúde Pública da SSA, e encontravam-se socialmente organizados em sindicatos, e na Associação Mexicana de Saúde Pública, como veremos.

A nova política pública de saúde, a qual visava estender o cuidar da saúde para a população aberta, continuaria a ser elaborada de modo conservador e autoritário, isto é, pelos velhos sanitaristas inseridos corporativamente na estrutura cêntrica autoritária mexicana, sem que houvesse o surgimento de novos atores e espaços na saúde que lograssem de fato dar um rumo distinto à política. A nova política encontrava-se expressa no Plano Nacional de Saúde de 1974-1983, formulado pelo quadro diretivo dos sanitaristas burocráticos corporativos da SSA. A fim de viabilizar o novo programa, a direção da SSA pretendia utilizar a infra-estrutura do IMSS para estender a cobertura da atenção a saúde para setores não assegurados. Tal intenção colocou em cheque a capacidade de viabilização do novo programa desde a sua formulação, tendo em vista que a política priista nunca tentou promover a atuação conjunta de IMSS e SSA na atenção a saúde. Pelo contrário, os dois subsistemas públicos de saúde sempre foram tidos como autônomos, direcionados a distintos públicos alvos, traduzindo-se em moedas de troca e controle político do PRI.

Em 1973 Echeverría promulgou uma nova Lei do Seguro Social, segundo a qual o IMSS deveria servir de base para a implementação dos novos programas em favor de grupos 
até então marginalizados do Seguro Social (via IMSS ou ISSSTE sobretudo), “dando inicio à chamada solidaridad social” (Soria, 1988, p. 196). No mesmo ano foi lançado o Programa Solidaridad Social, destinado a incrementar a cobertura médica básica e o acesso a medicamento a zonas marginalizadas. Apesar de ter um escopo limitado, Solidaridad Social sofreu oposição por parte de vários setores sociais, como sindicatos, sobretudo do IMSS, e empresários. O alto grau de resistência dos grupos privilegiados pelo sistema de saúde do IMSS à reformulação da máquina IMSSiana para estender o cuidar da saúde para a população aberta, assim como ocorreu com Solidaridad Social, se mostrará como obstáculo freqüente na reforma mexicana, cujas implicações políticas seriam evidenciadas, interpretadas e aprendidas pela elite política no decorrer dos sexênios. Trabalhadores e sindicato do IMSS, bem como a indústria de saúde, que fornece praticamente a metade de seus produtos para o sistema hospitalocêntrico IMSSiano, se opuseram a qualquer tipo de reforma que pudesse resultar na alteração dos interesses e/ou status já conquistados por eles (López Acuña, 1980) (Barajas, 2002) (Soria, 1988).

Ademais, Solidaridad Social foi criticado por conter metas muito gerais de intervenção no sistema, que "resultam de um conjunto de imprecisões e de promessas (...) com um tom de propaganda e doutrinário próprio dos piores momentos da retórica oficial” (López Acuña, 1980, p.222). Como ressalta Barajas (2002), evidencia-se na prática micro da política que a intenção do plano era antes garantir a volta de uma certa normalidade da situação política, questionada pelos movimentos sociais, do que estender a atenção da saúde à população não assegurada. Este Plano acabou sendo definitivamente cancelado. "Em 1977 o subsecretário de Planejamento da SSA declarou que o Plano Nacional de Saúde era utópico e impossível de ser adotado na prática por falta de recursos econômicos, porque não avaliaram seus objetivos e por causa do tom irreal de suas metas” (López Acunã, 1980, p.222).

A baixa viabilidade política de Solidaridad Social, evidenciada pela oposição acirrada ao programa, bem como pelas críticas decorrentes de sua precária implementação, evidenciam que o cuidar da saúde da população aberta continuava a ser pensado/implementado de forma estado-cêntrica, isto é, pela elite política inserida na esfera estatal, sem levar em conta os interesses da sociedade. As mudanças efetuadas no público possuem um caráter políticodemagógico. 


\subsection{Os anos de Portillo (1976 a 1982): não-participação direta e inserção do conservadorismo político-econômico neoliberal na política}

Dado o fracasso de Solidaridad Social em incrementar o acesso a saúde para a população não assegurada, o primeiro ano do governo de Portillo foi marcado por um silêncio $^{44}$ em termos de propostas da saúde. Este silêncio foi interpretado como "uma atitude reticente a empreender qualquer transformação sanitária (...) uma política de imobilismo que trata de ocultar (...) a crise, as desigualdades, a ineficiência e as grandes carências dos (...) serviços de saúde” (López Acuña, 1980, p.223).

Esta ausência de proposta política na saúde também sofria influência da crise econômica, reinstaurada no início do sexênio. Apesar de Portillo ter criado uma nova secretaria $^{45}$ (Secretaria de Programación y Presupuestos, SPP) no intuito de promover a coordenação da área econômica com os demais ministérios, no decorrer dos primeiros anos do sexênio a nova SPP mostrou-se incapaz de efetuar tal coordenação, bem como de propor mudanças na política econômica e nas demais políticas públicas, como esperava o Presidente.

Foi apenas no final do primeiro ano, ainda num contexto de restrição econômica e de contenção do gasto de saúde, que a SSA propôs um novo programa, buscando estender a cobertura de saúde para zonas marginalizadas. Trata-se de mais uma política de escopo limitado: o Programa de Extensão de Cobertura dos Serviços de Saúde ao Meio Rural e Suburbano (o PEC). Este, de forma semelhante a Solidaridad Social, foi construído a partir da própria esfera política macro, a fim de legitimar a perpetuação do PRI do poder. Também

\footnotetext{
44 As atividades do governo neste ano se reduziram a várias reuniões, seminários e mesas redondas, como tentativa do partido em não perder o espaço em setores, como o de saúde, que estavam sendo crescentemente ocupados pelas críticas da oposição.

${ }^{45}$ Ao assumir o governo Portillo objetivava mais promover o consenso e o equilíbrio do que promover mudanças; sua principal missão era resolver os desajustes provocados pelas transformações de Echeverría. Efetuou uma reforma administrativa na qual se destacou a criação da Secretaria de Programação e Orçamento (Secretaria de Programación e Presupuestos - SPP). A SPP era composta por três subsecretarias - programação, orçamento e avaliação - o que lhe permitiu controlar as políticas públicas, como também agrupar funções que antes eram desenvolvidas pela Fazenda, Sepanal e Presidência. A esfera de intervenção da SPP era bem extensa, sendo responsável pela coordenação de numerosos programas como a Coordenação Geral do Plano Nacional de Zonas Deprimidas e Grupos Marginalizados (COPLAMAR). “A Secretaria de Programação e Orçamento é uma supersecretaria: controla o orçamento e se conecta com as regiões. Estes dois ramos a concedem um controle quase total sobre o resto da administração pública” (Rousseau, 2001, p. 123). A SPP foi primeiramente entregue a um grupo de economistas estruturalistas, encarregados de formular um projeto viável de desenvolvimento para o país. No entanto, a atuação desse grupo não se mostrou politicamente desejável nos primeiros anos de Portillo. O grupo estruturalista não conseguiu nem estabelecer uma articulação com as demais secretarias, nem formular o projeto alternativo de desenvolvimento tão esperado pelo Presidente.
} 
consistiu num projeto político de baixa viabilidade de implementação, e portanto criticado como um programa politicamente improvisado (López-Acuña, 1980) (Barajas, 2002).

O Estado pretendia cobrir as necessidades de saúde da 13.666 localidades utilizando-se de auxiliares de saúde comunitária. Estes auxiliares foram contratados e treinados pela SSA, e eram constituídos em sua maioria por mulheres com baixo nível de escolaridade, residentes em comunidades entre 500 e 2.500 habitantes. O resultado do PEC ficou bem a baixo do esperado, pois além da falta de capacidade do pessoal, os serviços coordenados pela SSA não possuíam condições político-institucionais e de recursos humanos para a implementação das diretrizes formuladas, que pretendiam cobrir as necessidades de saúde de 28 milhões de pessoas (LópezAcuña, 1980) (Soria, 1988). Ademais, o treinamento realizado pelos técnicos da SSA, ao limitar-se à transmissão de saber sobre primeiros socorros médicos, sem contemplar as demais carências da comunidade, não possibilitou o engajamento do pessoal treinado. Não houve também o surgimento de novas práticas sociais na saúde, como em algumas cidades do Brasil Brasil. Há que se assinalar aqui que, devido ao aprendizado com o programa anterior, o quadro diretivo da SSA manteve o IMSS dissociado do PEC, a fim de evitar conflitos com a instituição.

Contudo, este novo fracasso dos velhos sanitaristas do PRI, que compunham o quadro diretivo da SSA, havia revelado ao Presidente a incapacidade do grupo em realizar um programa que pudesse ampliar a cobertura de saúde com um menor custo político possível.

Assim como na área econômica, a crise evidente da área de saúde (da SSA) também revelava a necessidade de se efetuar mudanças substantivas no seu quadro diretivo.

Cabe ressaltar aqui que a formulação e implementação dos novos programas de governo, como Solidaridad Social e o PEC, seguiram ainda um padrão de legitimação política autoritário-conservador, caracterizado pelo baixo nível de comunicação entre esferas políticas macro e micro e esfera social; em que a renovação do que é público visava antes remediar a situação de crise e assim garantir a perpetuação da elite no poder, do que atender às necessidades de saúde de grande parte da população. Além de possuir um escopo limitado à atenção médica simplificada, e ser direcionada restritamente ao público marginalizado de algumas zonas urbanas e rurais, esses programas também apresentavam baixa viabilidade política. Num contexto de crise política estrutural da MEC, em que a crise econômica mostrava-se politicamente determinante - antecedendo e sobrepondo-se à democratização da 
política -, a mudança na saúde apresentou intervalos de ruptura seguidos de indecisão sobre os rumos das políticas públicas. Estas políticas mantinham um formato político e fiscalmente centralizado, e se caracterizavam antes como programas de solidariedade, do que de universalização do público.

\subsubsection{A gênese da inserção do conservadorismo neoliberal na política de saúde não- assegurada no México: novo grupo e velhos espaços.}

Foi em decorrência desse inter-relacionamento socialmente perverso entre as exigências da economia e a necessidade de reformulação das políticas públicas da MEC que a política de saúde para a população aberta, assim como as demais políticas públicas, passaram a ser modificadas em meados de 1979. Certamente estas mudanças foram beneficiadas pelo boom petroleiro, contudo tiveram seus sentidos orientados decisivamente pelas modificações efetuadas por Portillo na chefia da SPP. Uma vez que o grupo estruturalista não se mostrou “capaz de lançar uma corrente renovadora, o que explica o mau funcionamento daquela supersecretaria até 1979” (Rousseau, 2001, p.144), paradoxalmente Portillo acabou entregando a chefia da SPP para um grupo de monetaristas. Estes, por estarem ligados a Echeverría, haviam sido afastados do centro de decisão pelo próprio Presidente no princípio de seu governo. Configurava-se o tempo inicial de formação de uma nova elite política na MEC mexicana, a qual, a partir do Ministério da Fazenda, e mais exatamente da super SPP, passaria a comandar os rumos das políticas públicas e das demais relações da esfera política mexicana.

O formato das políticas públicas, para as quais seriam destinados os recursos emergenciais subjacentes ao programas de desenvolvimento social, passou de fato a ser definido pela super Secretaria de Programación y Presupuestos (SPP), conjuntamente com o Presidente. Sob a chefia de De la Madrid, e com supervisão direta de um grupo de economistas, chefiados pelo jovem Carlos Salinas, a super SPP selecionava os grupos alvos dos programas, como também escolhia as instituições públicas que propiciariam uma execução mais rápida e eficaz das ações sociais. Sob a chefia de De la Madrid e já com a atuação de Carlos Salinas a SPP: 1) lançou um novo programa para estender os serviços de saúde para regiões marginalizadas e 2) contratou uma avaliação do setor público de saúde para um grupo de especialistas articulados fora da SSA. 


\section{O programa IMSS-Solidariedad}

Dado o fracasso do $\mathrm{PEC}^{46}$ em estender a cobertura de saúde por meio da atuação dos velhos sanitaristas e do uso da estrutura da SSA, a elite política da SPP decidiu estabelecer um convênio com o IMSS, que possuía uma ampla rede no país, e com a COPLAMAR ${ }^{47}$, que estava sob a jurisdição da SPP. Tratou-se do convênio IMSS-COPLAMAR, segundo o qual o IMSS deveria implementar um programa de atenção médica dirigido a 10 milhões de pessoas residentes em zonas marginalizadas, conjuntamente com a COPLAMAR. Para tal foram construídas, já no contexto do boom petroleiro, uma rede de duas mil unidades médicas rurais e urbanas e 52 clínicas em zonas indígenas e outras áreas marginais das cidades. As 3.000 unidades clínicas do IMSS espalhadas por todo o país, também deveriam ser utilizadas por este subsistema. Ademais, todo o financiamento do IMSS-COPLAMAR foi coberto com recursos do governo federal, mediante transferência direta para o IMSS, e não para a SSA.

IMSS-Coplamar foi economicamente viabilizado pelo boom petroleiro e implementado num contexto em que persistiam as mobilizações sociais pelo país. Nesta ocasião, a oposição mais acentuada às políticas do governo provinha do movimento de sindicatos independentes, com destaque para os sindicados de professores e mestres (da UNAM), que se transformou em movimento nacional ${ }^{48}$. A inconformidade dos sindicatos independentes foi politicamente canalizada pelo governo Portillo por meio da reforma política (Cansino, 2000). Esta deu oportunidade para estes sindicatos participarem das eleições para deputados de 1979. A liberalização política foi um meio utilizado por Portillo para conter os movimentos sociais e lograr a estabilidade do regime. Como conseqüência da reforma, os sindicatos voltaram sua atuação para a atividade partidária, fazendo recrutamentos, reuniões e outras atividades de igual natureza. Entretanto, ao permitir o retorno legal dos partidos de esquerda para a arena política, como o Partido Comunista que perdera seu registro, a reforma paradoxalmente

\footnotetext{
${ }^{46}$ Programa de Extensão de Cobertura dos Serviços de Saúde ao Meio Rural e Suburbano.

${ }^{47}$ Coordenação Geral do Plano Nacional de Zonas Deprimidas e Grupos Marginalizados.

48 Na transição política mexicana o movimento social que se destacou foi o da educação. Veja o livro de Joe Foweraker: Popular Mobilization in México: The Teachers’ Movement 1977-87, Cambridge University Press, 2002. Para ver a forma como a atuação do partido de Estado restringiu outros movimentos veja os artigos do livro States, Parties, and Social Movements (organizado por Jack A. Goldstone, Cambridge University Press, 2003).
} 
possibilitou a formação de uma ampla frente partidária de esquerda, constituída pelo Partido Socialista Unificado de México (PSUM) (Cansino, 2000).

Apesar dos esforços do governo Portillo, as medidas de saúde não acompanhavam o incremento da população rural e de zonas marginalizadas. Grande parte da população continuava sem acesso a serviços de saúde após a implementação de IMSS-Solidariedad $^{49}$ (Como ficou conhecido o convênio IMSS-COPLAMAR). Ademais, com o incremento dos aportes de recursos destinados ao IMSS, aumentavam-se as desigualdades e fragmentação dentro do sistema público de saúde (López-Acuña, 1980). Verificou-se a conformação de uma estrutura a mais dentro do subsistema de saúde direcionado para a população aberta. Embora esse subsistema fosse tradicionalmente encabeçado pela SSA e seus serviços coordenados, a extensão da cobertura de saúde da população não-assegurada estava se dando por meio do IMSS. Mostrou-se politicamente mais eficaz estender a cobertura de saúde por meio do IMSS (no seu sub-setor IMSS-Solidariedad), ao invés de promover uma reforma que visasse melhorar a capacidade de atenção da SSA. Esta nova política não exigia nenhum tipo de coordenação entre SSA e IMSS. Este teria autonomia na implementação do programa. Daí o porquê da ausência de conflito entre IMSS e SSA nesta nova fase de mudanças na política de saúde, diferentemente dos anos de Echeverría.

Paradoxalmente, a implementação de IMSS-Solidariedad se deu por meio da reprodução das práticas de socialização IMSSianas. De forma que o setor privado ampliava sua inserção no público reproduzindo, juntamente com o pessoal de IMSS-Solidariedade, as práticas de fraude/corrupção e não-prestação de contas hegemônicas no setor. O setor privado também estendeu consideravelmente sua rede de prestação de serviços médicos no decorrer da década de 1970. Daí o porquê do setor privado ter dobrado sua participação no gasto de saúde no início dos anos 80 (Soria, 1999).

Em meio a perpetuação das estruturas e mecanismos políticos da MEC, o domínio público-estatal não assegurado mexicano herdava não só a publicidade positiva do IMSS, considerado publicamente como ícone do comprometimento do PRI com a sociedade, como também as práticas institucionais socialmente perversas e de saúde curativa de alto custo.

\section{Consultoria junto aos futuros especialistas em economia da saúde}

\footnotetext{
${ }^{49}$ Veja análise de López-Acuña (1980), Victor Soria (1988) e Brachet-Marquez (2001), na bibliografia.
} 
No entanto, a viabilidade política do novo programa solidário foi mais uma vez posta em cheque no México. Tratou-se de um cheque-mate político economicamente determinado. Com a queda do preço do petróleo em meados de 1981, a própria elite da SPP reconheceu que a duplicidade de gasto do governo federal com as instituições direcionadas para a população aberta (SSA e IMSS-Solidariedade) não compreendia uma forma racional de alocação de recursos da economia e, assim, mostrava-se como um problema que deveria ser equacionado pela política pública de saúde. Foi neste contexto que o Presidente e a nova elite política do Ministério de Finanças deram início a um processo de redefinição da política pública para a população aberta. De forma mais explícita, a chefia da SPP recusou-se a continuar utilizando o quadro diretivo da SSA para pensar um novo programa de saúde para o México, adequado às novas constrições da situação político-econômica interna, e da economia mundial.

As questões da economia da saúde, associadas às novas temáticas de administração das políticas públicas, começaram a se inserir na agenda política mexicana. No novo cenário, a política de saúde continuou a apresentar um escopo conservador, contudo diferenciado do conservadorismo político desenvolvimentista. O novo conservadorismo estado-cêntrico priista residiu no fato da nova elite política em formação ter construído ainda de forma nãoparticipativa na saúde - isto é: de cima para baixo, sem a influência direta de movimentos contra-hegemônicos de saúde no processo de decisão (Quadro 3.3)-, uma política pública que se encontrava no tempo inicial de integral social (da população não-assegurada) e de redefinição do domínio público na saúde. Contraditoriamente, a decisão política seria norteada, de um lado, pelo conservadorismo extremado da ortodoxia econômica da nova direita já hegemônica na política internacional e, de outro, pelo ideário pós-revolucionário que legitima o poder do PRI perante a população em geral. A possibilidade de democratização do acesso público-estatal aos serviços de saúde mostrou-se, portanto, pouco provável no processo de transição em curso.

De la Madrid contratou um grupo de médicos dissociados dos velhos sanitaristas do PRI para fazer uma avaliação e propor mudanças no setor saúde. Não se tratou de grupo defensor da Medicina Social, em reformulação na América Latina desde meados dos anos 70. No âmbito da estrutura da MEC mexicana, e num contexto de lenta e ainda inicial transição do regime político, não havia espaço para um grupo crítico de medicina coletiva. Este, 
representado no México pelo Mestrado em Medicina Social da UAM Xochimilco, se encontrará à margem da política priista.

O grupo convocado pela SPP era representado por Dr. Guillermo Soberón de Acevedo, um pesquisador da área biomédica, com tradição em pesquisa laboratorial, correspondendo portanto uma ruptura no padrão de elaboração das políticas de saúde da SSA, até então sob o comando dos velhos sanitaristas do partido de Estado. Como ressalta Soberón, “De la Madrid disse que estavam gastando muito dinheiro com os dois programas, e não havia uma racionalidade para tomar decisões (....) decidiu que era preciso fazer uma investigação completa para avaliar a questão da saúde, e me chamou” (Soberón-Acevedo, entrevista, 2003). A contratação de um especialista para fazer uma avaliação justificava-se não apenas porque a equipe queria ter informações com base nas quais pudesse tomar decisões que visassem a racionalização dos recursos empregados; mas também porque o novo grupo, chefiado por De la Madrid e apoiado pelos empresários, almejava a Presidência da República. A realização de um bom trabalho na SPP era a forma de obter o apoio de Portillo para sua candidatura ${ }^{50}$.

Por sugestão da SPP, ou melhor, de De la Madrid, Portillo criou em 11 de agosto de 1981 a Coordenação dos Serviços de Saúde da Presidência. "Fui nomeado para esta Coordenação e me deram um mandato que dizia: esta coordenação deve determinar os elementos econômicos, técnicos e administrativos dos serviços públicos de saúde” (SoberónAcevedo, 2003). Sob a chefia de Soberón a Coordenação deveria "estudar a possibilidade de integrar as diversas instituições de saúde em um único Sistema de Nacional de Saúde. Pela primeira vez uma equipe de técnicos especialistas proporia políticas para a unificação de todas as instituições públicas provedoras de serviços de saúde” (FUNSALUD, p. 56-57).

O êxito do conjunto de estratégias e táticas ${ }^{51}$ adotadas por De la Madrid na chefia da SPP fez com que ele fosse apontado como o candidato de Portillo à Presidência, sendo formalmente nomeado como candidato oficial na Sexta Convenção Nacional do PRI em outubro de 1981. Ressalta-se que "O fato de que a SPP se converteu em plataforma de

\footnotetext{
${ }^{50}$ Rousseau faz uma análise detalhada da estratégia política executada por De la Madrid dentro da SPP, evidenciando que o então secretário já tinha por alvo a sucessão presidencial.

${ }^{51}$ A causa principal do êxito de Miguel De la Madrid e seu grupo nesta maratona para a presidência é a apresentação e logo aplicação do Plano Global de Desenvolvimento (PGD). Para o chefe da nação é prova suprema da aptidão para governar, pois demonstrava a capacidade intelectual para definir políticas públicas, globais e setoriais, com vista a aumentar a racionalidade administrativa, mas também a habilidade política para lograr a aceitação de novos programas (Rousseau, 2001, p.138).
} 
lançamento para a Presidência representa uma inovação de peso no sistema político mexicano, o qual reflete uma mudança nos mecanismos de representação e legitimação do sistema” (Rousseau, 2001, p.139).

Em julho de 1982 De la Madrid foi eleito Presidente. A crise econômica explodia, com o aumento das taxas de juros internacionais e o agravamento do déficit externo e interno mexicano. Já com a sucessão presidencial garantida, Portillo decretou a nacionalização dos bancos ( $1^{\circ}$ de setembro de 1982), projetada em secreto pelo Executivo. Como resultado, acirraram-se os conflitos entre Presidência e empresariado, os quais consistiram no questionamento “da regra de ouro do sistema político mexicano, isto é, a máxima de que o Presidente não é apenas o árbitro de última instância, como também o decisor de última instância na política e na economia” (Cordera Campos e Sánchez Rebolledo, 2001, p.469).

Foi em meio à crise político-social e econômica que, em outubro, Soberón entregou sua avaliação para o Presidente. "Eu disse ao presidente para convidarmos os secretários estaduais e o pessoal do IMSS para apresentarmos o resultados da investigação. No entanto, Portillo disse que não, pois o sexênio já estava terminando. Apresentei então os resultados do trabalho para um pequeno grupo: em que estavam o atual presidente Portillo e o presidente eleito (De la Madrid). O trabalho foi publicado em livro e implementado com De la Madrid” (SoberónAcevedo, entrevista, 2003).

O caráter repentino da crise transformou o ambiente da sucessão presidencial e aprofundou as tensões entre o Estado e os atores de sua coalizão política dominante, e entre o Estado e os diversos atores sociais, que se encontravam normativamente inseridos na aliança política com a Constituição de 1917. A crise econômica, somada aos conflitos político-sociais, evidenciava o esgotamento da formula Estado-cêntrica, na administração dos interesses em aliança com o Estado.

A reforma da saúde deveria ser implementada por uma nova elite governamental e nos moldes de um novo padrão de desenvolvimento, o qual compreenderia rupturas e continuidades com a matriz cêntrica mexicana. Entre as continuidades se encontrou a extensão das políticas de saúde para a população aberta, as quais se tornaram essenciais para o novo padrão de desenvolvimento. A novidade, que ainda não implicava em rupturas, se deu com a proposta de descentralização, limitada aos serviços coordenados pela SSA. 


\section{Crise Estado-cêntrica no Brasil, programas comunitários e luta política pela democratização na saúde}

De forma semelhante ao México, foi a partir do contexto de crise da política Estadocêntrica que surgiram políticas públicas de saúde voltadas para a população aberta no Brasil. Esta crise se deu no momento em que se esgotou o modelo econômico interno, conhecido como o milagre brasileiro, a com a sucessão de um novo governo. O desenvolvimento da economia, que sempre se constituiu como um dos principais fatores de legitimação do regime militar e como principal elemento de coesão da coalizão civil-militar no poder, foi posto em cheque. Com o incremento das pressões sociais ocasionadas pelos efeitos da política econômica, fazia-se necessário conciliar politicamente o aprofundamento do desenvolvimentismo econômico com intenções de políticas sociais menos autoritárias. Esta intenção mostrou-se explícita nas diretrizes do Segundo Plano Nacional de Desenvolvimento. Tratava-se da percepção do novo Presidente da República, que tinha como projeto efetuar uma distensão lenta, gradual e segura. O intuito era antes manter os militares no poder, do que dar início a um processo de democratização da política e das políticas públicas (Aguirre e Saddi, 1997) (Saddi, 1999).

Foram portanto em tempos de crise da política Estado-cêntrica pós-revolucionária mexicana e da situação autoritária brasileira, que ambos países começaram a produzir políticas de saúde orientadas para a extensão do acesso ao cuidar de saúde para o público não assegurado. Nestes contextos, a extensão do acesso público a saúde mostrava-se politicamente significativa tanto para a continuidade do PRI, como para a continuidade da aliança civilmilitar brasileira no poder. No Brasil, diferentemente do México, a crise da situação militar se deu apenas após 10 anos de um regime militar de tipo bipartidário, enquanto no México esta crise se evidenciou após 50 anos de hegemonia de um regime autoritário de partido único. Brasil já havia passado por 15 anos de democracia, possuindo portanto uma matriz cêntrica mais flexível e menos estável em relação à mexicana, como vimos no capítulo anterior.

\subsection{Os anos do governo Geisel - a consolidação do movimento sanitário e as políticas de saúde do governo}

\subsubsection{O movimento social na saúde}


No caso brasileiro, distintamente do mexicano, as mudanças na saúde não se limitavam às políticas públicas originadas na esfera política macro. A atuação do movimento médicosocial crítico na saúde, conhecido como movimento sanitarista, mostrava-se como o grande diferencial no processo de mudança na política pública de saúde brasileira. Houve no Brasil uma retomada e reformulação da crítica que se fazia ao sistema de saúde brasileiro no período da democracia populista, antes do período militar, quando o Ministério da Saúde havia sido politizado por representantes da esquerda. Esta retomada ocorreu primeiramente nos Departamentos de Medicina Preventiva (nas Faculdades de Medicina), em formação em estados representativos no território nacional desde o início dos anos 70. Foi marcante nesta época a influência exercida pelo pensamento crítico de Juan César Garcia, sanitarista argentino, que se encontrava na OPS. Contudo, diferentemente da situação de isolamento da Medicina Social mexicana, a Medicina Social brasileira exerceu um duplo papel nesta fase inicial de surgimento de políticas públicas mais extensivas ao público em geral. Sua atuação se deu tanto na esfera social quanto na esfera política.

A conformação dos departamentos de medicina preventiva, bem como a influência deste pensamento nas escolas de saúde pública, contribuiu para a divulgação de um marco de idéias alternativo em saúde coletiva. Esta ressalta que "a saúde e a doença na coletividade não podem ser explicadas exclusivamente nas suas dimensões biológicas, porquanto tais fenômenos são determinados social e historicamente, enquanto componentes dos processos de reprodução social. Tal percepção, portanto, permitia alargar os horizontes de análise e de intervenção sobre a realidade” (Paim, 1997, p.13). Esse marco de idéias asseverava a necessidade de se realizar "uma totalidade de mudanças que passava pelo setor saúde e implicava alterações mais profundas em outros setores, no Estado, na sociedade e nas instituições” (Paim, 1997, p.13). Este entendimento amplo do que vem a ser saúde, e que se traduziu numa proposta audaciosa de mudança social e política, teve como representantes militantes do Partido Comunista, bem como simpatizantes de outros segmentos progressivos e/ou da esquerda. Não se tratava de um grupo partidário, visto que aglutinava diversas facções em torno de si, no entanto se tornariam conhecidos como partido sanitário no decorrer da democratização (Escorel, 1998).

Este marco renovado da saúde coletiva brasileira contribuiu para a formação de uma nova geração de jovens médicos sanitaristas, os quais levaram a crítica teórica para a prática 
comunitária. Esta prática pode ser exemplificada pelo movimento médico social de Campinas $^{52}$, em que uma facção dos estudantes do Departamento de Medicina Social da Faculdade de Ciências Médicas da UNICAMP começaram a realizar trabalho comunitário junto à população residente no cinturão de pobreza que cercava a cidade na ocasião (Lavras, entrevista 2003) (Silva, entrevista 2003).

Ao efetuarem um novo processo de construção da atenção médica junto a comunidade, transferindo conhecimento, exercendo uma socialização comprometida antes com o relacionamento humano do que com o cuidar da doença, e assim, indo mais além da intervenção curativa, o movimento não só agia de forma socialmente distintiva do complexo de saúde INAMPSiano, como também deu início a um processo destinado a construir mudanças no entendimento da população sobre o significado e alcance do que vem a ser público na saúde. Tratava-se certamente de uma construção ainda inicial, limitada às cidades e espaços em que estes movimentos estavam ocorrendo. Esta construção, mesmo para as pessoas que participaram de tal momento, mostrou-se ainda parcial, tendo sua abrangência e perpetuação condicionada pelo modo como esta nova prática iria, no decorrer da transição política, se transformar em política, influenciando e pressionando os demais atores envolvidos publicamente na prática do cuidar da saúde. (Lavras, entrevista 2003) (Silva, entrevista 2003)

Assim como em outras cidades, representantes deste movimento viriam a ocupar lugar de destaque na Secretaria Municipal de Saúde, quando a esquerda progressista do MDB assumiu prefeituras de Municípios, bem como se constituiriam em secretários de saúde do município/estado e exerceriam posições chaves no Ministério da Saúde e em conselhos nas décadas seguintes. A política de saúde passou a ocupar o segundo lugar de importância na plataforma política destas cidades, já nos anos de Geisel (Silva, 2003). No caso de Campinas e São Paulo, esta geração de sanitaristas encontrava-se engajada em movimentos sociais da periferia nos respectivos municípios, articulando a nova pauta da agenda social, tentando fazer o Estado incorporar essa agenda como parte das políticas publicas (Saes, 1988) (Merhy, entrevista 2003) (Lavras, entrevista 2003).

A Escola de Saúde Pública da USP também teve um lugar de destaque na construção da política de saúde. No curso se encontravam médicos sanitaristas como Eduardo Jorge, David

\footnotetext{
52 Sobre os outros movimento de saúde no período Veja Escorel (1998) e Saes (1988), na bibliografia.
} 
Capistrano Filho e Emerson Elias Merhy. De forma que além de se mostrar como um núcleo de formação da liderança do movimento de saúde da Zonal Leste ${ }^{53}$, a Saúde Pública da USP também aglutinava o grupo que formaria o Centro Brasileiro de Estudos de Saúde (CEBES). Este, sob a liderança de nomes como David Capistrano Filho e Ermerson Merhy, surgiu em 1976 por iniciativa da então turma da Saúde Pública. O intuito era formar um núcleo crítico de discussão sobre saúde. Para tanto foi articulada uma rede de conversa em âmbito nacional a fim de propor a formação da nova entidade. Tal processo é relatado por Merhy: "Levamos a idéia para Sociedade Brasileira para o Progresso da Ciência (SBPC) de Brasília de 1976 e, numa reunião com 50 pessoas, percebemos que se tratava de uma vontade coletiva. Resolvemos então fazer um lançamento nacional dessa idéia. Até dezembro de 1976 a idéia estava centralizada em São Paulo, mas depois de um ano já tínhamos 5 mil pessoas afiliadas. Esta sinergia prova que já havia um movimento favorável no país, tanto na academia quanto nas periferias. Este último era um movimento clandestino de esquerda, que se traduzia em luta contra a ditadura. Tudo isso somava-se à tradição que já vinha dos anos 50/60 de fazer a crítica à política pública da saúde. Não éramos iguais, mas estávamos juntos em torno da luta pela democracia e pelo direito social” (Merhy, entrevista 2003).

Representantes da medicina social brasileira também produziram diversos estudos importantes de crítica ao modelo vigente, propondo alternativas para a sua reestruturação. Daí o porquê do período Geisel ser caracterizado como o de formação de um arcabouço de idéias da reforma sanitária brasileira, bem como de consolidação do movimento sanitário (Levcovitz et al., 2003). Este movimento contra-hegemônico, embora já percebido pelo governo, ainda não influenciou diretamente as decisões tomadas por Geisel.

\subsubsection{Os projetos de saúde do governo na gênese da liberalização política}

No decorrer do período Geisel as decisões de políticas públicas mostravam-se arbitrárias e norteadas por um alto grau de centralização política ${ }^{54}$. Nesta fase, o compromisso do governo era com a nova coalizão política, na qual o empresariado tinha papel de destaque, diferenciando-se dos anos anteriores, em que o capital internacional ocupava lugar de destaque.

\footnotetext{
53 Sobre o movimento da Zona Leste veja livro de Saes (1988), na bibliografia.

${ }^{54}$ O Presidente Geisel controlava todas as políticas públicas. A posição/palavra do Presidente de fato definia o rumo das políticas do país. Seja na área da política econômica, seja nas modificações político-partidárias, como também na área social. Veja recente análise de Elio Gaspari em A Ditadura Derrotada, Companhia das Letras, 2003.
} 
A nova política social proposta pelo governo visava antes conter/evitar o aprofundamento das pressões sociais, do que implementar de fato uma política social transformadora que visasse estender o acesso de saúde para a população.

De forma contraditória, mas politicamente significativa, as políticas públicas de saúde do governo revelavam a intenção de administrar as tensões e pressões sociais decorrentes da crise do modelo econômico. De um lado, o governo lançou mão de novas políticas de intervenção na saúde, por meio dos chamados projetos de extensão da cobertura da atenção básica, inspirados pelas instituições internacionais. De outro, não só mantiveram a estrutura do INPS, como também a dividiram, criando uma instituição destinada apenas ao cuidado médico da seguridade social: o INAMPS.

Dentre os projetos criados no período Geisel destacou-se o Programa de Interiorização de Ações de Saúde e Saneamento (PIASS) ${ }^{55}$ de 1976. Este programa foi criado por um comitê (GEIN - Grupo Executivo Interministerial) composto por representantes dos Ministérios da Saúde, de Seguridade Social, do Interior e da Agricultura e Planejamento, sob a coordenação do Ministério da Saúde.

Com o PIASS representantes do movimento sanitário começaram a se inserir no Ministério da Saúde, já no decorrer da elaboração do projeto. Esta participação se deu por meio da criação de uma Secretaria técnica de apoio ao GEIN, a ST/GEIN. Esta teve como primeiro coordenador o médico sanitarista Nelson Rodrigues dos Santos. O programa, elaborado conjuntamente com a Previdência, encontrou resistência direta do empresariado do setor médico privado, representado no INAMPS. O projeto elaborado não teve por alvo criar programas de atenção de segundo nível, própria das redes de hospitais hegemônicas. O objetivo era implementar postos e centros de saúde no Nordeste e em zonas marginais urbanas, utilizando o orçamento da Saúde e da Seguridade Social, como limitado pela SEPLAN. O projeto enfatizava o uso das estruturas públicas existentes nos municípios e o envolvimento da comunidade na atenção médica, dando menor ênfase no papel do médico especializado. Tratava-se portanto de um projeto de medicina simplificada, não integral, e limitado a algumas regiões. No entanto, já se conformava um processo inicial de participação política dos

\footnotetext{
55 Antes do PIASS foi adotado o PPA, constante no II PND, e programas de vacinação. Ver análise de Escorel (1998).
} 
sanitaristas, na esfera política, que se estenderia também ao futuro CONASS no governo seguinte, como veremos.

Há que se ressaltar ainda que, comparativamente aos programas solidários mexicanos, o PIASS contribuiu para estreitar o vínculo do MS com os quadros políticos dos municípios e estados (Silva, 2003). Ademais, o PIASS foi executado juntamente com várias experiências de saúde comunitária, voltadas para a implementação de uma rede básica de saúde nos municípios já sob o comando da oposição, o MDB.

O programa acarretou o incremento da cobertura de saúde à atenção médica simplificada nos municípios envolvidos, tendo como modelo o Projeto Montes Claros (Escorel, 1998). No entanto, estima-se que o PIASS atendeu apenas $25 \%$ da população alvo. Seu fracasso foi atribuído ao ainda incipiente processo de descentralização administrativa, aliado à existência de práticas institucionais que têm norteado a execução das políticas públicas no país. A implementação do PIASS caracterizou-se, de um lado, como um processo extremamente dependente da estrutura central, norteado pela excessiva burocratização e demora na aquisição de novos imóveis e pela conseqüente falta de equipamentos, à escassez de recursos. De ouro lado, nos municípios em que havia uma articulação com a comunidade, começava-se a processar uma forma diferenciada de socialização na execução do projeto do governo. Em Campinas, por exemplo, o PIASS somou-se ao projeto comunitário, permitindo o incremento de recursos e a inauguração de postos de saúde na cidade (Lavras, entrevista 2003) (Silva, entrevista 2003.

Há que se destacar ainda que o programa encontrou resistência dos médicos envolvidos na prática curativa no INAMPS/setor privado. Em Campinas, por exemplo, esta resistência foi intensificada após dois eventos significativos: o fechamento de um hospital de pediatria e após a queda acentuada do número de consultas ginecológicas no INAMPS. Neste, houve um movimento de greve liderado pelos médicos (Lavras, entrevista 2003).

A implementação do PIASS apresentou contradições derivadas dos interesses envolvidos na esfera política, mas os quais se articularam - no decorrer da implementação com os da esfera social. Esta interação política se deu na luta realizada dentro do GEIN em articulação com a Previdência, no vínculo estabelecido com a política estatal e municipal, e na mobilização e engajamento da comunidade em construção em algumas cidades. 
No que se refere à modificação efetuada no sistema público hegemônico da seguridade social, Geisel criou em 1977 o Sistema Nacional de Previdência e Assistência Social (SINPAS). Este era formado, de um lado, pelo IAPAS (Instituto de Administração Financeira da Previdência Social), que passou a administrar a parte financeira da Previdência, e, de outro, pelo INAMPS (Instituto Nacional de Assistência Médica da Previdência Social) que ficou responsável pela assistência médica da previdência. Com esta divisão, O INAMPS passou a ser a instituição hegemônica nas ações de assistência médica pública no Brasil. O intuito desta divisão era efetuar mudanças no modelo médico, não conforme as reivindicações da saúde coletiva. Difundiu-se o discurso de que o aumento dos serviços por meio de convênios era, tecnicamente, a alternativa mais correta, uma vez que amenizariam os custos econômicos com a assistência médica dos assegurados. No entanto, implementou-se de fato uma política mais acirrada de privilegiamento do setor médico privado no domínio público-estatal, no que se refere à atenção a saúde.

Como conseqüência, aprofundou-se o processo de privatização, visto que a participação do setor privado na assistência médica, através dos convênios e credenciamentos, tornava-se cada dia maior, com o governo investindo cada vez menos em sua rede própria. No início da década de 80, por exemplo, cerca de 70\% das verbas destinadas à assistência médica ia para as mãos dos empresários da saúde, e o INAMPS chegou a comprar, naquela mesma época, 300.000 leitos a hospitais particulares e disponibilizar apenas 7.800 de sua rede própria. Continuava-se a praticar na atenção pública as mesmas práticas perversas de socialização ${ }^{56}$ em relação aos anos de linha dura. Neste contexto houve um fortalecimento do setor médico privado no Brasil, e o surgimento da medicina de grupo representada pela ABRAMGE (Cordeiro, 1984).

No final dos anos 70 tornam-se públicos os sinais de esgotamento da prática médica INAMPSiana. As intermináveis filas, baixos salários e precárias condições de trabalho geravam uma insatisfação crescente da população com a qualidade da assistência. A mágerência dos recursos, aliada aos episódios cada vez mais crescentes de corrupção, levou a

\footnotetext{
${ }^{56}$ Além de privilegiar uma prática médica socialmente excludente e alto custo - essencialmente curativa, centrada na técnica, privilegiando as ações de maior sofisticação tecnológica - o serviço médico privado, conveniado com o Estado e pago através da Previdência, criava um estímulo à corrupção. Ficaram bastante conhecidos, na década de 70, os famosos escândalos da Previdência Social, onde hospitais privados consumiam o dinheiro do contribuinte com procedimentos e pacientes fantasmas.
} 
Previdência a um colapso. Como fator agravante, a Previdência começou a 'envelhecer' e a fase de captação de recursos foi substituída pela de maiores gastos.

\subsection{Os anos de Figueiredo - anos de negociação política}

Dado o caráter autoritário do governo, a influência do movimento sanitário sobre a política ainda não se dava de forma direta na gênese da transição do regime político. Tal influência só ocorreu de forma mais acentuada no governo de Figueiredo, quando a crise econômica, caracterizada pelo estrangulamento externo e déficit fiscal interno, passou a demandar uma solução política para a crise financeira do INAMPS. Tratava-se também do período em que o novo General presidente já havia perdido o controle do processo de abertura, e em que não se podia mais conter/reprimir politicamente a publicidade crítica em relação às fraudes e escândalos do sistema INAMPSiano. À medida que o processo de abertura política se ampliava, com a oposição tendo vitórias significativas nas eleições parlamentares, o movimento sanitário foi se ampliando e a ele foram sendo incorporadas lideranças políticas regionais e populares, bem como parlamentares interessados na causa.

Foi portanto com o governo Figueiredo que se iniciou a fase de participação política mais direta do movimento sanitário na esfera política e, mais especificamente, na política pública de saúde. Esta articulação com a esfera estatal pode ser verificada nas discussões realizadas no Congresso Nacional, na elaboração da política pública de saúde no INAMPS em articulação com o Ministério da Saúde, bem como na implementação da política pelas Secretarias estaduais e municipais de saúde.

O primeiro marco dessa fase ocorreu em 1979, no I Simpósio Nacional de Política de Saúde, realizado pela Comissão de Saúde da Câmara dos Deputados. O Centro Brasileiro de Estudos de Saúde (CEBES), tido como o legítimo representante do movimento sanitário, apresentou e discutiu publicamente pela primeira vez uma proposta de reorganização do sistema de saúde. Essa proposta, que já se chamava Sistema Único de Saúde, contemplava diversos conceitos oriundos de experiências bem sucedidas em outros países, como a universalização do direito à saúde, racionalização e integralidade das ações, democratização e participação popular. Também levava em consideração algumas experiências de atenção primária e de extensão de cobertura desenvolvidas no país, como o Programa de Interiorização das Ações de Saúde e Saneamento (PIASS) e o Projeto Montes Claros em Minas Gerais. 
Foi neste contexto avançado da abertura política e de discussão pública sobre a política de saúde que a questão da extensão de cobertura assistencial nos níveis estaduais e municipais começou a fazer parte do discurso oficial. Representantes do movimento sanitarista passamram a compor quadros do INAMPS e atuaram na elaboração do próprio plano do governo de reorganização da assistência à saúde: o PREVSAÚDE. Este plano possuía características muito semelhantes ao projeto do movimento sanitário, pois previa a implantação de uma rede de serviços básicos, apontava para a descentralização do setor, pregava a participação popular e a integração dos Ministérios da Saúde e da Previdência.

Ademais, o PREVSAÚDE foi amplamente discutido na VII Conferência Nacional de Saúde (CNS). Esta conferência, diferentemente da Conferência anterior, organizada de forma arbitrária e fechada, se deu num clima de expectativa pela participação de vários profissionais e estudiosos dos serviços de saúde vinculados não apenas ao pensamento oficial, como também à vertente crítica da saúde coletiva. Tendo como principal tema A Instalação de uma Rede Básica de Serviços de Saúde, a VII CNS trazia para a discussão política a sonhada extensão da cobertura da saúde.

Apesar da ampla articulação política em tono do PREVSAÚDE, e do reconhecimento da falência do sistema INAMPSiano também por parte de alguns técnicos do governo, o plano não foi implementado. Isto ocorreu porquê os interesses privados inseridos no público INAMPSiano bloquearam qualquer tentativa de alteração do status quo que lhes era conferido. As grandes corporações e associações médicas, em especial a Federação Brasileira de Hospitais (FBH), defendiam acirradamente a continuação do modelo curativo que lhe rendia lucros. Contudo, há que se destacar que mesmo não sendo concretizado, o PREVSAÚDE foi um marco da participação do movimento sanitário na política pública do governo federal. Também correspondeu a um momento importante de debate público nacional em torno dos rumos da política de saúde.

No Brasil, diferentemente do México, a discussão do sistema de saúde para a população aberta vinculou-se ao questionamento do modelo médico da seguridade social e à necessidade de se romper definitivamente com o cuidar médico não apenas exclusivo à classe trabalhadora, como portador de crise financeira e de práticas de saúde que beneficiam antes o privado do que a população em geral. No México, as tentativas de implementação de políticas mais extensivas à população não foram acompanhadas de críticas ao modelo IMSSiano. Este continuou a 
manter-se autônomo do sistema da SSA. No Brasil, de forma distinta do México, os atores críticos ao modelo vigente se inseriram na esfera estatal, dando início a um processo de luta visando uma ampla redefinição do público na atenção a saúde. Ademais, esta luta relaciona-se com a crítica ao próprio regime militar e a defesa da redemocratização no país.

Devido ao bloqueio efetuado pelo setor privado ao PREVSAÚDE, a Presidência da República criou, na própria Previdência Social, o Conselho Consultivo da Administração de Saúde Previdenciária (CONASP). Neste novo foro o processo de elaboração da política pública deu-se de forma distinta do PIASS. Este consistiu num grupo de consulta do MS, enquanto o CONASP formou-se como um conselho da própria Previdência. A formação do novo grupo de consulta mostrou-se politicamente significativa, uma vez que, dado o contexto mais avançado da abertura política, com o surgimento de vários outros movimentos sociais no país, esse confronto de diferentes interesses em busca de resolução para a crise da Previdência traduziuse, já na elaboração da nova política, num processo mais democrático de legitimação da decisão política. Enquanto as políticas mexicanas continuavam a ter um padrão autoritário de decisão, as brasileiras caracterizavam-se como um processo inicial de democratização na decisão da política pública.

Com o CONASP o movimento sanitário ocupou pela primeira vez cargos de chefia num Ministério. Como ressaltou o próprio Eleutério Rodrigues Neto, “Em maio de 1983, após vários meses de pressões e contra-pressões , o presidente do INAMPS me designou como novo diretor do PLAS (Departamento de Planejamento do INAMPS) de acordo com a indicação do Secretário de Planejamento e com o tácito reconhecido apoio da esquerda da área da Saúde. Essa nomeação representou, sem dúvida, uma significativa vitória para o movimento sanitário, que pela primeira vez tinha um de seus principais quadros ocupando um cargo considerado estratégico da administração federal da área da Saúde. (...) essa valorização pode ser feita a posteriori pelo que significou a abertura da instituição a novos quadros do movimento, pelo franqueamento de informações até então monopolizadas pelos estamentos burocráticos conservadores, pelo próprio avanço do processo político representado estrategicamente pelas AIS” (Rodriguez Neto, 2003, p. 47)

Mostrou-se politicamente significativa a forma como se deu o início do processo de participação do movimento sanitário na estrutura INAMPSiana. A inserção da proposta radical do movimento no CONASP ocorreu por meio de uma articulação da cúpula inserida com sua 
base, pois se sabia que a luta a ser travada dentro do INAMPS dificilmente possibilitaria modificações no sistema vigente. De acordo com Eleutério Rodrigues Neto, “O envolvimento de reconhecidos integrantes do movimento sanitarista na laboração da proposta criou uma situação de perplexidade e de constrangimento. Tal situação não podia ser discutida publicamente, na medida que as informações sobre a proposta e sua intenção (apresentá-la aos candidatos e ministros) foram transmitidas em caráter sigiloso e era de tal forma constrangedora que inviabilizava o expediente do eventual vazamento” (Rodriguez Neto, 2003, p. 43). No entanto o sigilo intencionado pela política autoritária, que, certamente, teria resultado na decisão por uma política autoritária, como ocorreu no México, foi rompido pela “estratégia de vazamento” realizada pelo movimento.

De forma que a elaboração do plano mostrou-se também norteada por algumas das demandas do movimento sanitário, as quais haviam sido tornadas públicas não apenas nas discussões do PREVSAÚDE e da VII CNS, como também na ocasião de um simpósio ocorrido no Congresso Nacional. A estratégia seguida também foi relatada por Eleutério Rodrigues Neto: “aproveitou-se a realização de um Simpósio Nacional de Políticas de Saúde, na Câmara dos Deputados, para ‘vazar’ a versão então válida do anteprojeto do Plano CONASP, na qual ainda havia uma indefinição e um certo privilegiamento do convênio empresa (medicina de grupo). Estando presente no evento representantes das duas correntes, orientou-se a discussão para 'desgastar' qualquer medida que pudesse favorecer o convênio empresa. Dessa forma, o próprio plano do CONASP foi alvo de muitas críticas nesse aspecto, sendo legitimado em outros” (Rodriguez Neto, 2003, p. 44).

O embate político evidentemente se mostrou acirrado na burocracia do INAMPS ${ }^{57}$, mas já em meio à publicidade crítica em torno do setor privado, que resultou em ganhos de legitimidade para a proposta do movimento sanitário. De forma contraditória, mas politicamente significativa, as estratégias decorrentes desta correlação de forças inseridas na esfera política ainda pendiam para o lado do setor privado, visto que propunham mormente racionalizar as crescentes despesas do sistema INAMPSiano, a fim de incrementar a produtividade e eficiência na atenção médica e, assim, a redução dos gastos no setor.

\footnotetext{
57 Para detalhes sobre a luta travada no decorrer da elaboração plano, veja o segundo capítulo do Livro de Eleutério Rodrigues Neto (2003), na bibliografia.
} 
Dentre as medidas elaboradas destacou-se, de um lado, o Plano de Reorientação da Assistência à Saúde, conhecido como Plano CONASP. Este possibilitou a realização de convênios trilaterais, entre o MS, MPS e SES, produzindo alguma transferência de poder para os estados no período. De outro lado, destacaram-se as mudanças relacionadas ao sistema de pagamento/transferência para unidades de saúde e hospitais.

O CONASP criou as famosas Autorizações de Internações Hospitalares (AIHs), um sistema que visava controlar o gasto com as internações hospitalares. As internações deixavam de ser remuneradas por unidade de serviço, como na anterior GIHs (Guias de Internações Hospitalares), e passavam a ser remuneradas por diagnósticos e procedimentos hospitalares. Com efeito, o planejamento passou a ser orientado por parâmetros de demanda e oferta de serviços, contribuindo para reforçar o modelo médico-curativo hegemônico, em detrimento da promoção de uma maior integração com o nível básico de atenção. Politicamente, a mudança atendeu aos interesses do público privado inserido na saúde. As AIHs se mostrarão contraditórias aos interesses da própria reforma sanitária, e se constituirão, nos anos seguintes, numas das principais problemáticas do futuro SUS, herdadas do sistema INAMPSiano.

Apenas em 1984, também de modo politicamente significativo, implementou-se o projeto de descentralização do CONASP, com a realização dos convênios com estados e municípios, dando início a um processo de unificação do sistema. Esta maior articulação do sistema havia sido politicamente evitada pelo setor privado, inserido no INAMPS, desde o PIASS. Em 1984, contudo, no último ano da 'situação autoritária', marcado pela movimentação em torno das Diretas Já, e em meio ao aprofundamento de um duplo processo de construção na saúde, que ocorria na esfera política e social, o CONASP implementou as Ações Integradas de Saúde (AIS), que se constituíram na primeira experiência de um sistema mais articulado e integrado no país.

Além da realização de convênios entre as três esferas federativas - União, estados e municípios -, direcionadas para o desenvolvimento de ações de saúde pública e assistência médica, verificou-se também o surgimento das Comissões Inter-institucionais de Saúde (CIS), os embriões dos futuros Conselhos de Saúde do SUS. Com estes conselhos, iniciou-se, portanto, um processo de participação social inclusiva na política municipal e estadual, em grande parte do país. Por representar também o início mais sistemático da descentralização, as AIS são tidas como a base para a implementação - já na redemocratização, no ano seguinte -, 
do Sistema Unificado e Descentralizado de Saúde (SUDS), a primeira aproximação estratégica para o futuro Sistema Único de Saúde (SUS).

Várias das administrações municipais que tinham tomado posse em 1982, assim como algumas administrações estaduais, entre as quais se destacam São Paulo e Paraná, aproveitaram o contexto das AIS para promover avanços no processo de descentralização da saúde. Multiplicaram-se as experiências municipais bem sucedidas de implementação de políticas de saúde. A experiência da cidade de Campinas ${ }^{58}$, por exemplo, foi levada para a cidade de Itaú, na ocasião em que Sebastião Mores assumiu a Secretaria de Saúde daquela cidade. No caso de Marília, com a posse do MDB, a cidade efetuou convênio com as AIS, criando a sua Secretaria de Saúde, que inexistia até a ocasião. “O prefeito empossado escolhe um secretário de saúde que se mantém durante todo o período de governo bem articulado com o movimento sanitário” (Silva, 2001, p. 154). Ressalta-se aqui que, de forma semelhante a outras cidades brasileiras, que não vivenciaram o processo de movimento comunitário da saúde nos anos anteriores, iniciou-se em Marília um processo de criação de redes básicas de saúde, em aliança com o hospital Universitário, tido como referência.

As AIS são caracterizadas como o momento inicial do processo de reforma de saúde no Brasil, ou melhor, como estratégia inicial de reversão da condição centralizadora e socialmente excludente do sistema INAMPSiano. No entanto, como ressalta Amélia Cohn, as AIS criaram “a situação paradoxal de que os recursos do INAMPS, originários fundamentalmente da contribuição dos assalariados, passam a se fundir nos gastos com assistência médica da população em geral (Cohn, 1999, p. 47). Esta duplicidade de gastos com os recursos previdenciários deveu-se ao fato de não ser possível efetuar uma conversão radical no modelo público com base tão-somente nos interesses construídos na esfera social, ou mediante um consenso político-moral sobre as necessidades de saúde de grande parte da população brasileira. Isto ocorreu devido a existência de interesses cristalizados no INAMPS e à oposição do setor privado.

A luta pela transformação do domínio público-estatal "privatista e exclusivo ao previdenciário” em “público extensivo a toda a sociedade”, por meio da unificação do sistema, isto é; da incorporação das atividades médicas da Previdência no Ministério da Saúde, produziu

\footnotetext{
58 A Secretaria de Campinas, por sua vez, fica com Nelson Rodrigues dos Santos, um dos expoentes do movimento, vindo do PIASS.
} 
heranças institucionais/estruturais a serem enfrentadas no decorrer do processo de reforma brasileira. Esta herança, como veremos, será prolongada em distintos tempos políticos, assumindo formatos diferenciados, mas assumindo posição de destaque na agenda sanitarista no decorrer da próxima década. Este paradoxo, por se referir a um processo radical de mudança no sistema, o qual visa unificar o sistema previdenciário e o não-assegurado, não encontra paralelo na política Estado-cêntrica mexicana. Nesta, a autonomia do serviço médico do IMSS, mesmo quando utilizado para atender a população aberta, não é modificada.

Há que se ressaltar ainda que esta dificuldade, apesar do bloqueio ao PREVSAÚDE, não implicou na interrupção do processo inicial de desconcentração, tendo em vista que as AIS apresentaram uma continuidade em relação ao PIASS, aprofundando o processo de descentralização e já incorporando a participação de representantes do movimento sanitarista na decisão política. Para parte dos sanitaristas brasileiros, como Jairnilson Paim (1997), os problemas são vistos não como empecilho para o prosseguimento da reforma, mas como parte da luta política a ser travada, em seu devido tempo cronológico e político, ao longo da construção de um domínio público-estatal democrático e de atenção integral a saúde.

No Brasil, o movimento de saúde foi o precursor de todos os outros movimentos sociais que surgiram no contexto de redemocratização da vida política do país, após 83/84 sobretudo, já no contexto das Diretas Já. A questão da democratização e da descentralização da saúde encontrou adeptos seja na esfera social, seja na esfera política estatal. A crítica acadêmica/teórica ao sistema INAMPSiano traduziu-se em novas práticas implementadas na comunidade e conquistou espaço na política federal, estatal e municipal. Apesar da luta mostrar-se acirrada em virtude dos interesses privados já inseridos no espaço estatal, tratou-se de uma luta com alta legitimidade política, iniciada também (mesmo que de forma incipiente, e espacialmente localizadas) a partir da sociedade desde meados dos anos 70, e impossível de ser ignorada pela elite política no processo de transição democrática em curso, como mostra o surgimento das AIS em 1984.

No contexto da redemocratização brasileira não houve espaço para o predomínio político das políticas econômicas restritivas nesta fase inicial da nova ortodoxia econômica do mundo capitalista. Nos anos de Figueiredo, de modo distinto dos anos de Geisel, a política pública certamente vinculou-se de forma mais direta com as exigências de ajuste fiscal e de contenção de gasto, mas de forma politicamente distinta da política mexicana dos anos de 
Portillo. A política de saúde brasileira relacionou-se também ao processo de luta pela universalização da cobertura na saúde, que se confundiu com a própria luta pela democracia. Politicamente, tratava-se de processos distintos de reordenação do domínio público-estatal na saúde, orientados por lutas travadas nas esferas estatais, mas com características especificas aos interesses participativos na política.

\section{Conclusão: legitimações distintas do público no processo inicial das reformas de saúde.}

No decorrer deste capítulo vimos que por praticamente uma década, em dois governos específicos, no México e no Brasil, atores políticos de distintas naturezas começaram a participar do processo político, produzindo mudanças substantivas na natureza e escopo do domínio público, no que se refere à política de saúde para a população não assegurada (Quadro 2.1). Nos anos de Portillo, no México, o domínio público concernente à política de saúde continuou a ser definido de cima para baixo, sem a influência direta de mobilizações de saúde sobre a decisão. Esta mostrou-se orientada indiretamente, por mobilizações sociais que ocorriam em outras áreas (como na Educação), e mais diretamente, pelos interesses dos atores dominantes da esfera política: Presidência e Ministério da Fazenda (SPP), com a cooptação do novo grupo de economia da saúde. Neste sentido, podemos sugerir que México seguiu um padrão não-participativo de decisão na saúde (Quadro 3.3). Com o acirramento da instabilidade das relações políticas da MEC (no contexto de crise econômica com mobilização social), a coalizão em formação na SPP marginalizou os velhos sanitaristas do PRI, ainda na SSA, das decisões políticas. As problemáticas políticas e econômico-institucionais evidenciadas no decorrer da implementação eram utilizadas, pelo novo time de decisores, comandados pela super Secretaria do Ministério da Fazenda, como justificativa para se realizar uma redefinição no domínio público-estatal.

O caráter não-participativo do processo decisório na saúde possibilitou a produção de uma política de natureza ainda autoritário-conservadora, já influenciada, mesmo que de forma preliminar pelo conservadorismo extremado da nova ortodoxia econômica global $^{59}$. No contexto de crise fiscal com inflação e de lenta e inicial transição de regime político, a

\footnotetext{
${ }^{59}$ Adjetivo utilizado em referência ao domínio da política internacional, que, a partir da queda do Muro de Berlim, mais especificamente, apresenta uma proposta globalizante ou de caráter universal para a política econômica, nos diversos países do mundo.
} 
problemática do gasto/ineficiência mostrou-se politicamente mais significativa que as questões de eqüidade no acesso da atenção médica/democratização na saúde.

A relação autoritária existente entre esfera social e política, que redundou na nãoparticipação política direta de grupos críticos de saúde nas decisões estatais e, no não engajamento da sociedade no processo inicial de construção do domínio público-estatal, diferentemente do caso brasileiro, permitiu que os conflitos e críticas recorrentes da implementação desencadeassem um processo seqüencial de bruscas interrupções dos programas, revelando a baixa viabilidade política das reformas iniciadas. Tal dinâmica sóciopoliticamente perversa, revelada pelas políticas de Echeverría e de Portillo, deveu-se ao fato da redefinição não-participativa do domínio público-estatal na saúde ter pretendido antes construir bases solidárias de legitimidade para a perpetuação da política priista, do que de fato estender o acesso do público não-assegurado à assistência à saúde.

No Brasil, por sua vez, o processo de redefinição do domínio público-estatal, na saúde, começou a processar-se antes na esfera social, do que na política. Consolidou-se um movimento sanitário crítico independente da MEC, o qual promoveu práticas de saúde junto à comunidade, dando nova configuração ao significado de domínio público a partir da esfera social inclusive. A produção de novas políticas públicas, por sua vez, caracterizou-se pela participação política ainda limitada, mas já inclusiva aos novos atores sociais da saúde coletiva. As políticas criadas possuíam uma natureza ainda autoritária, mas já de cunho democratizante; orientadas progressivamente pelo processo de transição e de luta pela democratização da saúde. Nesta luta, a questão da eqüidade mostrou-se politicamente mais determinante, e restringiu a possibilidade de realização de ajustes ortodoxos na política pública. O escopo do domínio público-estatal na atenção médica limitou-se aos postos de saúde, como ocorreu com IMSSSolidariedade, mas com possibilidade política de universalização, de descentralização e de atendimento integral com a democratização da luta pela saúde.

Apesar dos acirrados conflitos com o setor privado e a burocracia do INAMPS, houve uma seqüência contínua de medidas/programas desde a formação dos DMPs, a realização de práticas comunitárias, passando pelo PIASS até às AIS. As políticas brasileiras apresentaram uma viabilidade política maior em relação às mexicanas, porquanto foram norteadas não apenas pelos interesses corporativos e privados, como também por valores já vivenciados, em alguma medida, e de forma diversa, na sociedade. A legitimação prévia do novo domínio 
público-estatal perante a sociedade, mesmo que diversa e parcial, restringiu a arbitrariedade da política autoritária macro (nacional), geradora de interrupções constantes na política pública mexicana. Num contexto de abertura política e de participação social e política na saúde, a estratégia da política brasileira passou a ser orientada não pela desconcentração, mas pela descentralização. Vinculou-se à luta por direitos sociais, e não a intenções de solidariedade política.

Quadro 2.1. Regularidades políticas do processo inicial de redefinição do significado de domínio público-estatal na política de saúde para a população aberta: México e Brasil.

\begin{tabular}{|c|c|c|c|c|}
\hline País & $\begin{array}{c}\text { Participação } \\
\text { política na } \\
\text { elaboração }\end{array}$ & $\begin{array}{l}\text { Natureza política da } \\
\text { redefinição do público }\end{array}$ & Escopo do público & $\Leftrightarrow \begin{array}{c}\text { Implementação } \\
\text { Elaboração }\end{array}$ \\
\hline $\begin{array}{l}\text { México } \\
\text { Solidariedade } \\
\text { Social, SS } \\
\text { PEC } \\
\text { IMSS- } \\
\text { Solidariedade }\end{array}$ & $\begin{array}{l}\text { Limitada aos } \\
\text { atores dominantes } \\
\text { da esfera política } \\
\text { Meados de 1979: } \\
\text { Presidência e } \\
\text { Ministério da } \\
\text { Fazenda (SPP), } \\
\text { com a cooptação } \\
\text { do novo grupo de } \\
\text { economia da saúde. } \\
\text { Não há participal } \\
\text { social Movimentos } \\
\text { sociais: não há } \\
\text { movimento } \\
\text { específico de } \\
\text { saúde, } \\
\text { independente da } \\
\text { MEC. }\end{array}$ & $\begin{array}{l}\text { Autoritária- } \\
\text { conservadora. Meados } \\
\text { de 1979: Política } \\
\text { orientada pela } \\
\text { necessidade de efetuar } \\
\text { ajustes na economia. } \\
\text { O tema da duplicidade de } \\
\text { gasto/ineficiência } \\
\text { econômica mostra-se } \\
\text { politicamente mais } \\
\text { significativo que a } \\
\text { questão da } \\
\text { equidade/democratização } \\
\text { na saúde. }\end{array}$ & $\begin{array}{l}\text { Estreito, com baixa } \\
\text { probabilidade de expansão } \\
\text { no decorrer da lenta } \\
\text { transição política, dado a } \\
\text { influência política da SPP } \\
\text { sobre a política de saúde, a } \\
\text { ausência de um grupo de } \\
\text { saúde coletiva inserido na } \\
\text { política priista, e o baixo } \\
\text { poder de influencia de } \\
\text { grupos sociais organizados } \\
\text { sobre a política da MEC } \\
\text { mexicana. }\end{array}$ & $\begin{array}{ll}\text { 1. } & \text { Conflito com atores tradicionais do } \\
\text { sistema - oposição do IMSS a SS } \\
\text { 2. Críticas as políticas. Políticas visam } \\
\text { amenizar a situação de crise, resposta } \\
\text { demagógica aos movimentos sociais. } \\
\text { 3. } \begin{array}{l}\text { Baixa viabilidade política das políticas: A } \\
\text { cada governo há uma recorrente }\end{array} \\
\text { interrupção e inexistência de continuidade } \\
\text { das políticas iniciadas. } \\
\text { 4. } \begin{array}{l}\text { Problema da sobreposição de gastos: } \\
\text { justifica politicamente a necessidade de }\end{array} \\
\text { uma política mais eficiente. } \\
\text { Desconcentração com IMSS- } \\
\text { Solidariedade (não com a SSA). A } \\
\text { Desconcentração traduz-se em } \\
\text { solidariedade da política. } \\
\text { Início do aumento da cobertura na saúde, } \\
\text { mas ainda insignificante. }\end{array}$ \\
\hline $\begin{array}{l}\text { Brasil } \\
\text { Práticas } \\
\text { comunitárias } \\
\text { PIASS } \\
\text { PREVSAÚDE } \\
\text { AIS }\end{array}$ & $\begin{array}{l}\text { Politicamente } \\
\text { limitada, mas } \\
\text { também já } \\
\text { extensiva aos } \\
\text { novos atores } \\
\text { sociais da saúde } \\
\text { coletiva. } \\
\text { Movimento } \\
\text { Sanitário crítico } \\
\text { independente da } \\
\text { MEC: nasce na } \\
\text { esfera social, } \\
\text { precursor dos } \\
\text { movimentos sociais } \\
\text { na transição } \\
\text { democrática. }\end{array}$ & $\begin{array}{l}\text { Autoritária- } \\
\text { democratizante. Política } \\
\text { orientada pelo processo } \\
\text { transição democrática, } \\
\text { luta pela democratização } \\
\text { da saúde. } \\
\text { Questão da equidade } \\
\text { mostra-se politicamente } \\
\text { mais determinante, e } \\
\text { limita a possibilidade de } \\
\text { se realizar ajustes } \\
\text { ortodoxos na política } \\
\text { pública. }\end{array}$ & $\begin{array}{l}\text { Ainda estreito, mas em } \\
\text { constante e crescente } \\
\text { processo de mudança, e } \\
\text { com possibilidade política } \\
\text { de expansão com a } \\
\text { democratização, tendo em } \\
\text { vista a ampla } \\
\text { permeabilidade da política } \\
\text { na sociedade e na política } \\
\text { municipal, bem como a } \\
\text { crescente inserção do } \\
\text { movimento sanitário na } \\
\text { esfera política } \\
\text { (federal/municipal/estadual). } \\
\text { Início do processo de } \\
\text { formação de uma política } \\
\text { pública a partir da } \\
\text { sociedade. }\end{array}$ & $\begin{array}{l}\text { 1. Conflito com setor privado e atores do } \\
\text { INPS/INAMPS. Apesar no conflito há } \\
\text { continuidade do PIASS com as AIS, } \\
\text { apesar do bloqueio ao PREVSAÚDE. } \\
\text { AIS ocorrem em processo avançado de } \\
\text { democratização: Movimento Diretas Já. } \\
\text { Viabilidade política das políticas: pressão } \\
\text { vinda de baixo, inserção na política de } \\
\text { novos atores na saúde, e } \\
\text { continuidade/retomada dos programas } \\
\text { adotados pelo governo federal (PIASS- } \\
\text { AIS), absorvendo demandas do } \\
\text { movimento sanitário. } \\
\text { Sobreposição de gasto: interpretada como } \\
\text { resultado da primeira tentativa de } \\
\text { unificação do sistema, e menos como } \\
\text { duplicidade de gasto. } \\
\text { Inicio da descentralização: influência de } \\
\text { programas comunitários, iniciativa } \\
\text { municipal, iniciativa do governo federal } \\
\text { (AIS). Descentralização implica na luta } \\
\text { por direitos sociais na saúde e por } \\
\text { autonomia política e fiscal. } \\
\text { Há um aumento significativo da } \\
\text { cobertura, mas ainda insuficiente. }\end{array}$ \\
\hline
\end{tabular}

Estas regularidades políticas de uma década corresponderam a um estádio preliminar, mas já politicamente caracterizado como processos de construção de legitimações distintas de 
um novo domínio público-estatal, concernente ao cuidar da saúde de mexicanos e brasileiros marginalizados no decorrer de décadas dos benefícios da seguridade social. Ao final dos anos de Figueiredo, a política pública de saúde para a população não-assegurada apresentou um padrão de legitimidade autoritário-democratizante, enquanto a política Mexicana, após meados do governo de Portillo, possuiu um padrão autoritário-conservador com tendência ao neoliberalismo. Estes padrões de legitimidade da política pública influenciarão o processo de reforma a ser desenvolvido nos anos seguintes.

No caso brasileiro, o contexto de redemocratização, aliado à participação dos sanitaristas em inserção na política macro-nacional e ao fortalecimento da participação social e política na luta pela municipalização - com o surgimento de milhares de conselhos em todo o território nacional - vão contribuir, já no período do governo Sarney, para a realização de uma discussão nacional sobre os novos rumos da política, ainda no momento anterior à concretização do seu primeiro marco legal. Os princípios do vindouro SUS resultarão dos conflitos travados e negociados no Congresso Nacional na Assembléia Nacional Constituinte (ANC).

Nesta, será marcante a atuação de alguns sanitaristas, que se converterão em atores políticos - deputados -, os quais travarão uma luta com grupos representativos da previdência e do setor privado. Contudo, a proeminência do setor privado na saúde brasileira impedirá politicamente que questões pertinentes ao financiamento do SUS sejam institucionalizadas em 1988. Daí o porquê da questão do financiamento ter ocupado lugar de relevo na agenda da saúde na década de 90. Ademais, a fusão do SUS com o INAMPS também será politicamente postergada. O SUS não apenas surgirá sem que haja a unificação do sistema, como também herdará as prática de remuneração INAMPSianas. A lei constitucional será criada para instituir a saúde como direito, e garantir legalmente os princípios e diretrizes do vindouro SUS, bem como a continuidade da construção de um projeto social que já havia nascido e já era realidade em alguma medida em alguns estados e municípios. Há que se reconhecer aqui o caráter pioneiro da saúde no Brasil, no que se refere ao fato dela dado início, mesmo que de forma incipiente, à construção de uma História Social no país.

No México, por sua vez, o contexto de lenta transição de partido único com reestruturação do modelo econômico dará condições políticas para a perpetuação de um padrão não-participativo de decisão na saúde da MEC priista (Quadro 3.3), já caracterizada pelo 
conservadorismo neoliberal. O novo ministro da saúde, sob o comando do Presidente De La Madrid e da elite do Ministério da Fazenda, articulará, a partir do próprio poder, as mudanças a serem efetuadas na política pública de saúde. Toda a legislação de saúde será arquitetada a partir da esfera política nacional. Um dos alvos da política será a transferência dos serviços de saúde para os estados; ainda dependentes do orçamento federal, com baixa capacidade administrativa, e que por décadas têm se relacionado de forma política e fiscalmente arbitrária com o governo federal. A imposição da redefinição do domínio público-estatal não coincide, portanto, com os interesses cristalizados nas instituições políticas de saúde, bem como se mostram diretamente antagônicas às práticas políticas e administrativas socializadas no decorrer de décadas no cuidar da saúde de mexicanos, como fraude/corrupção e não prestação de contas.

A oposição de governadores e do IMSS, somada ao acirramento da crise econômica, resultará na desconcentração de apenas 14 estados, e na interrupção do processo iniciado. Diferentemente do caso brasileiro, a construção de um novo domínio público-estatal na saúde será marcada por uma constante crise de legitimidade da política, revivida a cada fim de governo, ocasionando interrupções e bruscas mudanças na agenda e configuração das políticas de saúde nos governos seguintes. Esta dinâmica política instável se mostrará como uma constante no processo de redefinição de legalidades e de re-legitimação do poder nos três últimos governos do PRI no México, como veremos.

Ressaltamos, por fim, que os vínculos existentes entre participação e legitimidade mostram-se relevantes para se compreender politicamente os significados das mudanças efetuadas no domínio público-estatal - no que se refere ao cuidar da saúde da população aberta -, e em particular quando se trata de países de matrizes políticas estado-cêntricas, cujas elites políticas se restringiram a produzir políticas socialmente perversas até os anos 70, negando o acesso à saúde à um terço da população. O processo inicial de mudança analisado contém não apenas os principais atores que se apresentarão como protagonistas das reformas até 2000 no México, e até 1998 no Brasil, como já apresenta os principais desafios sócio-políticos a serem enfrentados/herdados nos anos seguintes. Trata-se de desafios relacionados não só aos conflitos/interesses políticos cristalizados, mas também aos problemas sócio-culturais logo estruturais, derivados de padrões de socialização nas instituições políticas e de atenção médica, interpretados como socialmente perversos no primeiro capítulo. 


\section{Capítulo 3 - Identificação e legitimação na construção da reforma pública de saúde: literatura de reforma de saúde e metodologia da análise}

Neste trabalho, o processo de descentralização da política pública de saúde, no México e no Brasil (de 1984 ao final da década de 90) será estudado, nas partes seguintes da tese, como um processo de legitimação de um novo domínio público-estatal, em construção nas esferas políticas macro (nacional) e micro (estadual no México e municipal no Brasil), e em articulação com a esfera da sociedade civil e econômica. Este capítulo pretende, primeiramente, apresentar o estado atual da literatura política sobre a reforma de saúde - e, mais especificamente no que se refere a sua contribuição para a problemática da legitimidade política das reformas - para, em seguida, ressaltar os principais conceitos e métodos a serem utilizados na análise proposta.

\section{A política e o estado da literatura sobre reformas públicas de saúde nos anos 90: a política como um problema de eficiência, de relacionamento ou de statecraft?}

Após praticamente duas décadas desde o início da implementação das reformas de saúde, as novas iniciativas de políticas públicas, revistas e regulamentadas nas distintas fases da reforma em cada país, correspondentes a diferentes tempos de transição político-econômica, ainda não foram capazes de resolver a problemática da eqüidade do acesso à atenção à saúde, nem mesmo as questões de eficiência no gasto e qualidade na oferta de serviços públicos de saúde para a população, e em especial, para a população de menor renda. Tais fatos, dentre outros, fez com que especialistas de políticas púbicas - das diversas áreas e sub-áreas do conhecimento - passassem a valorizar as relações políticas nacionais em suas análises, o que acarretou no incremento no número de análises políticas ${ }^{60}$ concernentes ao setor saúde desde

\footnotetext{
${ }^{60}$ Obviamente que a compreensão sobre o significado do termo política varia muito na literatura. Nas análises do Banco Mundial, por exemplo, como revelam os vários números do World Development Report desde o princípio década de 1990, a política é compreendida não apenas à luz do novo institucionalismo econômico; como regras que possibilitariam a criação de instituições estáveis e confiáveis, com capacidade de responsabilização (accountability) e transparência, na oferta de bens públicos, como também de forma associada ao conceito de governança internacional. Este termo, como ressalta o especialista em Política Internacional James Rosenau (1994), refere-se a objetivos comuns aos países (na ordem internacional) e que, na ausência de uma autoridade definitiva (como é caracterizada a ordem internacional, de natureza hobbesiana), sirva para estimular uma convergência transnacional das políticas econômicas internas e externas. Nas últimas décadas, como assinala a análise de Thomas J. Biersteker (2000), o termo "governança” tem sido utilizado sobretudo em referência a requisitos que garantiriam o domínio (governança) da política econômica neoliberal, reivindicada pela nova
} 
meados da década de 1990. A partir de então as relações políticas nacionais tendem a ser tratadas ou 1) como empecilho para o desenvolvimento do mercado (World Bank, 2004); ou 2) como problemáticas sócio-políticas singulares aos países em desenvolvimento, ou 3) como questões federativas, próprias das relações políticas micro (sub-nacionais - em sua vertente estadual e/ou municipal) ou 4) como temas específicos das relações sociais do cotidiano nestas sociedades ${ }^{61}$. Entretanto, ainda sabemos pouco sobre a forma como os atores políticos, que ocupam posições de poder nas distintas instituições estatais e países, têm participado dos processos (de decisão e implementação) da política pública de saúde, respondendo aos desafios vindos à tona na decisão e implementação. Sabemos menos ainda sobre os efeitos que as distintas interações políticas (entre o processo de decisão e de implementação, entre os níveis macro e micro da política) exercem sobre a dinâmica dos processos de políticas públicas com naturezas e escopos distintos, nos diferentes países e fases da reforma. Isto quer dizer que um dos grandes desafios para a investigação comparada relaciona-se à compreensão da dinâmica política macro-micro dos processos de mudança concernentes às reformas de saúde nas novas democracias (ou regimes políticos em transição) da América Latina.

Tal desafio ressalta não apenas a relevância de análises macro-micro dos processos de políticas públicas (decisão e implementação), como também requer a busca de um marco analítico que possibilite examinar, de modo inter-relacionado, 1) a forma como padrões de decisão política - os quais redundam na produção de políticas cujos escopos variam entre

ordem política internacional, de natureza unipolar (e não mais bipolar). Sobre a origem do termo “governança” e sua relação com o neoliberalismo veja texto de Thomas J. Biersteker (2000) “O 'triunfo' da economia neoclássica no mundo em desenvolvimento: convergência de políticas e fundamentos da governança na ordem econômica internacional”. Para uma crítica sobre a forma como as agências internacionais de fomento têm utilizado o argumento de governança (mais especificamente em sua vertente "governanaça democrática”) e, assim, afetado as políticas públicas dos países em desenvolvimento, veja o texto de María Fernanda Tuozzo (World Bank, Governance Reforms and Democracy in Latin America, In: Bulletin of Latin America Research, 23, vol.1, 2004), em que a autora critica o conceito de governança democrática à luz da crise na Argentina. Já para uma análise em defesa do uso do termo governança democrática veja o texto Democratic governance and sectoral policy reform: tracing linkages and exploring synergies - In: World Development, vol.28, n, 4, 2000 -, de Derik Brinkerhoff. Para este último autor "governança democrática” é um conceito neutro em relação às culturas locais, de abrangência universal e, por isto, eficaz para a análise de políticas públicas.

${ }^{61}$ Refiro-me a dois tipos de análises que se sobressaem na literatura de políticas públicas: 1) as análises que utilizam de forma politicamente autônoma (descontextualizada) o instrumental analítico do novo institucionalismo econômico, sem moldá-lo às relações Estado/Sociedade de cada país; e 2) as análises sociológicas que criticam o uso de ferramentas analíticas deslocadas da sociedade, por se basearem nos princípios e argumentos econômicos (ou de outros conceitos políticos normativos), para o entendimento de sociedades diversas e complexas em suas diversidades. Sobre o novo institucionalismo, veja a nota anterior. Sobre a crítica sociológica, refiro-me i) aos trabalhos sociológicos macro de autores como Peter Evans e ii) aos trabalhos que privilegiam a análise do cotidiano ou das relações políticas locais, utilizando os conceitos das chamadas novas sociologias da construção social (Corcuff), representada por Pierre Bourdieu e Bruno Latour, entre outros. 
estreitos (focalizados) e amplos (universais ou radicais) - têm impactado os processos políticos de implementação; e 2) o modo como os distintos padrões de decisão têm respondido aos novos e velhos problemas vindos à tona no decorrer das distintas fases de implementação nas novas democracias ou regimes em transição.

\section{Na última década a literatura internacional de Saúde Pública e Medicina Social tem} chamado a atenção para a necessidade de se ir além das análises hegemônicas de política pública, as quais sobrevalorizam a capacidade institucional e as questões de eficiência, conciliando-as com outros marcos analíticos a fim de que se possa compreender os processos de reforma de saúde não apenas do ponto de vista econômico formal ou de cunho técnico, mas como processos políticos e sócio-culturais singulares (Collins, 1996) (Walt, 1996) (Foltz, 1996). Como resultado, os autores têm ressaltado a necessidade de se enfatizar os diferenciais de pressões de grupos nacionais, internacionais e sociais no decorrer das reformas (Reich, 2002), bem como os distintos valores culturais e características organizacionais que poderiam explicar o porquê das dificuldades de implementação dos marcos legais idealizados e construídos $^{62}$ (Collins e Green, 1994) (Atkinson et al., 2000) (George, 2003).

Ademais, essa literatura internacional de Saúde Pública e Medicina Social também tem reconhecido que os desafios das reformas mostram-se por demais diversos, e complexos em sua diversidade, para serem tratados apenas pelas Ciências da Saúde. Representantes da Medicina Social em vários países, como Kornis e Rocha (1996) e Cohn (1992) (1999), no Brasil, Laurell (1996) (1995) e Castro (2003) no México, Tobar (2002) e Belmartino (2002) na Argentina, bem como Reich (2002) nos Estados Unidos, Griffiths (2003), Walt (1994) e McPake (2002) na Inglaterra, não apenas reconhecem a relevância do marco analítico das Ciências Sociais, como os utilizam amplamente em suas análises.

\footnotetext{
${ }^{62}$ No Brasil as análises de implementação ou sobre o poder local passam a ser privilegiada pelos investigadores do setor saúde nos anos 90. Amélia Cohn (1992) já em 1992 assinalava a necessidade de se estabelecer novas conexões entre o nível macro e o micro, bem como a relevância de se recuperar a análise da decisão política, utilizando-se de um marco teórico condizente com as especificidades do país e que produza novos conhecimentos sobre os desafios que se colocam na pratica para a saúde coletiva brasileira. Esta percepção, no entanto, não é unânime na saúde pública, ou melhor, na área de saúde coletiva no Brasil. Os autores que têm se especializado na análise de implementação de programas, como o Saúde da Família, por exemplo, mostram-se céticos em relação às decisões tomadas na política macro, chegando a desvalorizá-las em suas análises (Bodstein, 2002). Isto se deve à percepção de que as novas regulamentações não conseguem exprimir a amplitude da mudança ocorrida na implementação dos novos programas relacionados à família e, portanto, não reconhecem o desenvolvimento das novas práticas médicas e tipos de relacionamentos/envolvimento realizados no cotidiano junto à sociedade (Bodstein, 2002), (Pinheiros \& Mattos, 2001) (Pinheiros e Mattos, 2002).
} 
De formas politicamente distintas, porém complementares, conceitos como viabilidade política, responsabilização (accountability) e statecraft problematizam, do ponto de vista da política e mais especificamente da temática da legitimidade, as inter-relações existentes entre os processos de decisão e de implementação.

\subsection{Equipe de mudança e viabilidade política: a decisão como um problema do domínio ${ }^{63}$ econômico-institucional}

O conceito de viabilidade política, como utilizado por Thomas Bossert e Alejandra González Rossetti (1999), tem influenciado grandemente as avaliações e análises das reformas de saúde na América Latina. Os autores são os principais representantes do grupo de "Política e Governança” da Escola de Saúde Pública de Harvard. Esta é uma das Universidades centrais na disseminação do conhecimento na área de Saúde Pública, e o grupo liderado por Thomas Bossert ocupa uma posição determinante, se não hegemônica, sobretudo nas Américas, nas novas redes de conhecimento e de investigação formadas nos últimos anos ${ }^{64}$.

Em Comparative Analysis of Policy Processes: Enhancing the political feasibility of health reform, Bossert e González Rossetti (1999) sobre-enfatizam o processo de decisão, dando destaque para a necessidade de surgimento de uma equipe de decisores técnicos e eficientes para enfrentar os desafios. A ênfase dada à questão da eficiência é reiterada após a constatação de que as estratégias de segunda geração estavam sendo elaboradas em resposta aos fracassos das políticas de primeira geração, as quais foram direcionadas para a reestruturação econômica e o enxugamento do Estado, no contexto do ajustamento estrutural dos anos 1980 e início de 1990 . Vejamos de que forma esta constatação conduz os autores na escolha dos conceitos e marco analítico que orientarão a análise proposta por eles.

"O uso do conceito de time de mudança (change teams) faz parte do um pacote das estratégias dos decisores que buscam fortalecer a viabilidade política das iniciativas de reforma na saúde” (...) “A estrutura de análise proposta olha para o contexto político econômico, o processo de política pública, e para as estratégias políticas dos reformadores como três variáveis que afetam a capacidade do estado realizar reformas públicas de saúde. Ao

\footnotetext{
${ }^{63}$ Devido ao enfoque desta pesquisa de doutoramento, utilizo o termo “domínio” no lugar do termo "governança”.

${ }^{64}$ Veja texto de Lee e Goodman (2002) na bibliografia.
} 
fazer isto, a análise examina os fatores que determinam a viabilidade política da mudança na reforma da política pública” (Bossert e González Rossetti, 1999, p.3.)

Ressaltamos que dentre as três variáveis políticas assinaladas, a terceira - de acordo com os próprios autores, e como evidenciado nas conclusões de suas análises - é a determinante para se compreender por que alguns Estados da América Latina têm sido capazes de produzir novas mudanças, enquanto outros não. Os autores estruturam suas análises na teoria de agente principal, conciliando-a com o novo institucionalismo da economia. Para eles, o surgimento de uma nova equipe com capacidade de propor novas regras e instituições que permitiriam o desenvolvimento de um processo com maior (accountability) responsabilização e transparência - mostra-se determinante para a viabilidade política da reforma. Devido à própria limitação analítica da análise proposta, os autores têm privilegiado o estudo de países (e casos) em que não se verificou um movimento de saúde ou uma influência política direta da medicina coletiva na esfera política e/ou na esfera da sociedade civil.

\subsection{Responsabilização (accountability) como relacionamento e contexto}

Em Accountabilty in Health Services: Transforming Relationships and Contexts, Asha George (2003) utiliza o processo de implementação de um programa materno-infantil na Índia, a fim de verificar a forma como os atores se envolvem e participam da política (no nível micro, na implementação) e, assim, apresenta uma visão diferenciada sobre problemáticas objetivas (de racionalidade formal), como a dificuldade de accountability, vindas à tona no decorrer das reformas de saúde nos países em desenvolvimento ${ }^{65}$. O próprio autor relata-nos seus principais argumentos:

"Eu argumento que mecanismos de responsabilidade (accountability) podem servir como recursos importantes para mediar as relações entre usuários, provedores e administradores. Para que se possa superar as diferenças entre estes atores, eles devem ser capazes de se confrontarem com as relações de poder, melhorar a representação dos grupos marginalizados, e transformas relações em formas mais legitimadoras. A informação, o diálogo e a negociação são elementos importantes, pois permitirão a produção de mecanismos de

\footnotetext{
${ }^{65}$ Este tipo de analise tem sido amplamente utilizada no Brasil, sobretudo no que se refere à implementação do PSF em municípios de médio e pequeno porte.
} 
responsabilidade em relação aos problemas, gerando apoio ao aprendizado e mudanças no envolvimento entre os atores. Para que a responsabilidade (accountability) tenha sucesso, ela não pode ser vista como mecanismos adotados universalmente, sem considerar os contextos, práticas e atores. A responsabilização é melhor alcançada por meio de um processo de negociação interativo de representação dos participantes envolvidos e de relacionamentos no contexto em que ocorre. Aqui se encontram suas limitações, mas também o seu poder $^{\text {"66 }}$ (George, 2003, p.11).

Enquanto o conceito de viabilidade política vincula-se estreitamente com o perfil técnico da equipe de decisores, que deveriam elaborar e orientar a implementação de mudanças nos estados; o de responsabilidade associa-se estreitamente com o de relacionamento (contextualizado), e com a possibilidade de surgimento de formas mais legítimas de mudança. Observe ainda que enquanto o conceito de viabilidade política requer uma racionalidade eminentemente objetiva, limitando a viabilidade política à construção de regras formais e institucionais, o conceito de responsabilidade como relacionamento requer uma racionalidade não meramente objetiva, mas também subjetiva, condicionando a possibilidade de ocorrência de accountability a mudanças nas atitudes comportamentais de um ator ou grupo em relação ao outro. Estes dois trabalhos, apesar de possuírem escopos distintos, podem ser vistos como complementares, na medida em que nos permitem ressaltar a necessidade de compreensão dos processos de reforma como uma construção política e social. Vejamos agora como os dois conceitos relacionam-se com o de statecraft.

\subsection{Governabilidade como um problema de statecraft}

Ao recuperar a análise da política social como um problema de statecraft, em Statecraft, Social Policy and Governance in Latin America, James Malloy (1991) faz conexões analíticas, empiricamente embasadas, que nos permitem dá coerência e sentido sócio-político à complementaridade existente entre os dois conceitos a cima, amarrando-os analiticamente numa estrutura de análise Estado/Sociedade. Malloy (1991) demonstra que a crise de governabilidade é um tema antigo na América Latina e associa-se estreitamente à forma como os movimentos e grupos sociais organizados têm sido integrados na política. Na América Latina, as políticas sociais foram utilizadas pelos Estados para moldar/controlar a cidadania.

${ }^{66}$ Grifos meus. 
Daí o porquê dos direitos sociais se constituírem em privilégio para os setores trabalhistas ${ }^{67}$, sobretudo. Nestes países, prossegue Malloy (1991), o processo de ampliação da participação política mostrou-se contraditório, pois fez com que ações e associações institucionais de tipo racional-legal, como a prática burocrática especializada e a existência de instituições políticas formais (Constituição, partidos, direito de votar), convivessem com práticas institucionais de tipo patrimonialista, como clientelismo e corporativismo.

É preciso ressaltar que o resultado deste tipo de relação entre esfera política e social mostra-se não apenas socialmente, mas também politicamente perverso. Além das decisões políticas terem possibilitado o desenvolvimento de uma sociedade desigual e fragmentada, também não permitiu o desenvolvimento de mecanismos de integração social com alta legitimidade. A percepção da sociedade em relação ao domínio público-estatal, como a saúde pública e a atenção médica pública, mostra-se extremamente negativa, uma vez que o domínio público-estatal tende a ser tratado como privado e de privilégio de poucos. Daí o porquê da temática da mudança nos relacionamentos, como problematizada por Asha George (2003), mostrar-se politicamente significativa no que diz respeito não apenas à possibilidade de viabilidade política, mas em especial à possibilidade de criação de uma nova legitimidade para as novas políticas públicas para a população aberta.

\section{Métodos e conceitos da análise: notas teóricas e práticas sobre os vínculos entre processos políticos macro e micro}

Como já ressaltado, o processo de reforma da política pública de saúde, no México e no Brasil (de 1982/5 ao final da década de 90) será estudado, nas partes seguintes da tese, como um processo de legitimação de um novo domínio público, em construção nas esferas políticas macro e micro, e em articulação com a esfera da sociedade civil e econômica. Efetuaremos um estudo sóciopolítico macro-micro dos processos de mudanças, tendo por enfoque a análise da decisão macro e sua legitimidade em relação (em reciprocidade) ao processo político micro, e no que diz respeito às estratégias de descentralização. Estas, do ponto de vista das relações Estado/Sociedade, podem serão enfocadas como um processo de justificação do poder político como reivindicado pela esfera macro nacional. Ressalto que a estratégia de descentralização de

\footnotetext{
67 Os Estados da América Latina, diferentemente dos europeus, sempre foram caracterizados por terem um sistema de proteção social dual. De um lado, encontrava-se o sistema previdenciário hegemônico, direcionado para trabalhadores formais e organizados socialmente, e, de outro, os sub-sistemas para a população aberta.
} 
políticas sociais, e em particular da política de saúde, visavam integrar maior parte da população - isto é; a população não-assegurada - no arco de aliança com o poder, sendo politicamente apresentada como base de legitimidade para as políticas públicas construídas, reivindicadas como legítimas pelo poder macro nacional (Figura 3.1).

O problema da legitimação da nova política pública, legalizada e reivindicada como legítima pelas autoridades da esfera política macro nacional, porém dificilmente reconhecida e executada durante a decisão e implementação (na esfera política micro - estadual no México e municipal no Brasil) será relacionado à problemática da identidade, isto é: ao fato do "novo" ser construído não apenas por novos atores e instituições, mas também por atores e instituições portadores de uma identidade histórico-cultural e política e, portanto, ainda identificados com a velha concepção de domínio público que se pretende substituir/reformar. Tal problema será investigado ao verificarmos em que termos os valores e diretrizes legalizadas e reivindicados como públicos no processo decisório, ocorrido na esfera política macro, em cada fase da reforma e tempo de transição político-econômica, foram internalizados e realizados na esfera política micro e, assim, reconhecidos como legítimos no processo de decisão e implementação micro.

A pergunta central que propomos é a seguinte: de que forma os atores políticos e sociais envolvidos no processo de decisão e implementação micro da reforma de saúde, em distintas fases políticas do processo de construção, se identificaram com os valores e políticas produzidos/regulamentados na esfera política macro? A fim de respondermos à pergunta proposta, analisaremos primeiramente o processo decisório e, em seguida, o de implementação, em cada fase da reforma. Para então, na conclusão, termos uma visão de conjunto da dinâmica e das problemáticas políticas relacionadas ao processo de legitimação de um novo domínio público desde meados da década de 1980 até o final da de 1990. Neste capítulo apresentaremos o método e algumas categorias analíticas a serem utilizadas nas análises dos casos mexicano e brasileiro respectivamente.

\subsection{A decisão na esfera política macro: reivindicando a mudança no domínio público- estatal em tempos e seqüências distintas de transição político-econômica}

A análise do processo decisório macro será direcionada por uma pergunta principal: em que medida a produção de novas políticas e/ou regulamentações para saúde, em cada 
período e país, tem 1) legalizado-legitimado um processo de mudança que, em determinada medida, já ocorre na esfera política micro e na sociedade, ou tem 2) reivindicado uma mudança no domínio público-estatal “a partir de cima” tão-somente, sem levar em conta os interesses da esferas política micro e social. A nossa hipótese é que a reforma brasileira tende a se aproximar mais da primeira situação, enquanto a reforma mexicana se aproxima do segundo caso. No entanto, em nenhum dos dois casos deu-se um alto nível de aproximação entre valores e interesses das esferas macro e micro.

Seguiremos uma metodologia semelhante a dos capítulos anteriores. Isto é: em fases distintas da transição de regime político/ou democratização com reestruturação econômica, investigaremos o modo como atores de diferentes naturezas e interesses, os quais reivindicavam ou a democratização ou a focalização da atenção pública à saúde, se inseriram na esfera política macro nacional, participando diretamente do processo de luta pela redefinição do domínio público-estatal na saúde, produzindo políticas com naturezas, escopos e legitimidades específicas. Cinco perguntas inter-relacionadas nos conduzirão nesta análise:

1) Em que fase da transição de regime político/ou democratização ocorreu, em cada país, a formação de uma coalizão política articulada com os interesses políticos globais, de cunho neoliberal? Neste contexto de redefinição no domínio da economia, qual o peso que a Presidência, Ministério das Finanças/Economia e/ou grupos de economia da saúde - articulados com o domínio político da política econômica neoliberal (global ${ }^{68}$ ) e, portanto, comprometidos com a contenção do gasto público e, conseqüentemente, com a focalização do acesso público e a restrição da atenção médica ao nível básico -, passaram a ter sobre os processos decisórios macro-nacionais, em distintos tempos de transição de regime/democratização?

2) De que forma velhos atores - beneficiados pelo sistema público-estatal de tipo “hospitalocêntrico”, vigente desde os anos 30/40 e caracterizado pela não integração com níveis básicos de atenção -, como representantes da Seguridade Social

\footnotetext{
${ }^{68}$ Adjetivo utilizado em referência ao domínio da política internacional, que, a partir da queda do Muro de Berlim, mais especificamente, apresenta uma proposta globalizante ou de caráter universal para a política econômica, nos diversos países do mundo.
} 
(IMSS e INAMPS) e sistema médico privado, participaram do processo decisório da reforma, na esfera política macro?

3) Como os atores/movimentos contra-hegemônicos de saúde, comprometidos com um projeto de democratização da saúde, no que se refere à universalização do acesso e integralidade da atenção médica, atuaram em cada país e tempo de transição? Se e de que forma estes atores participaram diretamente do processo decisório na esfera política macro, em cada período?

4) Se e em que termos outros movimentos sociais, não ligados especificamente à saúde, influenciaram indiretamente o processo decisório macro, em distintos períodos de transição de regime/democratização com estabilização econômica?

5) De que forma os impasses, problemáticas e resultados do processo micro da política pública (decisão e implementação) de descentralização e/ou reforma, no período anterior, foram levados em consideração ou ignorados pelos atores inseridos em processos decisórios macro-nacionais, caracterizados por diferentes padrões de participação política direta (Quadro 3.1), em cada período e país?

Quadro 3.1. O tipo participativo e não-participativo de influência direta na decisão macro: segundo o critério "extensão ou representação da participação direta na decisão" (representação da PDD).

Decisão de tipo participativo: participação direta mais plural na decisão macro; com a influência direta da coalizão política hegemônica e do movimento contra-hegemônico de saúde.

Decisão de tipo não-participativo: participação direta muito restrita na decisão macro; Decisão limitada à coalizão política hegemônica no nível macro e time de mudança (grupo de consultoria e/ou elite do Ministério da Saúde ou Fazenda). Pode haver a influência indireta (apenas) de movimentos sociais, ou participação de caráter apenas formal (sem influência direta na decisão) de representantes políticos das esferas sub-nacionais de governo.

No caso brasileiro, pretendemos verificar se e em que termos a reforma da saúde mostrou-se politicamente significativa para o poder macro, no decorrer de todo o processo de democratização (1985-1998), e como o movimento sanitário continuou a ter lugar de destaque no processo decisório na esfera política macro (Quadro 3.2), contudo tendo sua participação politicamente limitada pelas ações do Presidente e/ou Ministério da Economia/Fazenda a partir do período de Collor, quando se deu a formação de uma coalizão política identificada com o projeto de estabilização econômica. 
No que se refere ao México, o intuito é investigar por que e como a reforma de saúde para a população aberta continuou mostrando-se politicamente significativa para o PRI no contexto da lenta transição de regime político com influência da política econômica neoliberal global; sendo elaborada, a cada período, a partir da esfera política macro, sem receber a influência de grupos contra-hegemônico em saúde, mas sendo lentamente influenciada pelas recomendações internacionais na redefinição do domínio público-estatal na saúde (Quadro 3.1) (Quadro 3.3).

A nossa hipótese geral para o processo decisório de cada país, separadamente e para os períodos estudados, é que, embora de forma distinta, verificou-se, tanto na reforma mexicana, quanto na brasileira, uma correlação positiva, mas não proporcional, entre pressões do domínio da política econômica neoliberal, de um lado, e limitação da influência indireta de mobilizações sociais ou de saúde no processo decisório, de outro lado. Esta correlação positiva ocorreu tanto no lento processo de transição de regime político no México (Quadro 3.3), quanto na nova democracia brasileira, entre os governos de Collor e de Cardoso ( $1^{\circ}$ governo) (Quadro 3.2).

Do ponto de vista comparativo, entretanto, tendo em vista os tempos e seqüências distintas dos processos de transição política-econômica, e, em especial, no que diz respeito à natureza dos valores e interesses dos atores inseridos na esfera política macro e em luta pelas reformas, a influência de domínio da política econômica neoliberal (ou ortodoxia econômica) sobre a agenda da saúde teve um peso diferenciado nos dois países. Isto se deu em virtude 1) do escopo (restrito ou mais plural) de participação no processo decisório na esfera política macro, bem como 2) das distintas modalidades de articulação da esfera política macro com o domínio da política econômica, com a esfera política micro e a esfera social.

No decorrer da análise comparada, a ser realizada no fim de cada seção (da Parte II e II) e conclusão, pretendemos privilegiar o critério representação ou extensão da participação direta na decisão (PDD), utilizando-o como indicador de reciprocidade da decisão macro em relação aos valores e interesses do domínio público-estatal de saúde vigente em cada país (Quadro 3.1). Segundo este critério, os requisitos de domínio da política econômica neoliberal mostram-se mais determinantes no desenho e construção política da reforma de saúde no padrão restrito de PDD; uma vez que a decisão tende a ser orientada diretamente pelos interesses da coalizão política e time de mudança no Ministério da Saúde e/ou Fazenda. Já no padrão mais plural de 
PDD, por sua vez, os requisitos de domínio da política econômica neoliberal se encontram em luta com as reivindicações dos representantes políticos e do movimento sanitário inseridos na esfera política macro. As reformas no domínio público-estatal da saúde, neste último caso, mostram-se menos condicionadas pelos critérios de domínio da política econômica e menos contraditórias aos interesses do domínio público-estatal de Saúde do país (Quadro 3.1).

A nossa hipótese comparada, para o processo decisório macro, é que a influência do domínio da política econômica neoliberal sobre a agenda da reforma da saúde para a população aberta, embora ocorrida com um ritmo lento nos dois países, se mostrou, por fim, maior no padrão restrito de PDD mexicano (Quadro 3.3), do que no padrão mais plural de PDD brasileiro (Quadro 3.2).

Quadro 3.2. O padrão mais plural de participação direta na decisão macro: Brasil; de Sarney a Cardoso, 1998.

\begin{tabular}{|c|c|c|c|c|}
\hline $\begin{array}{c}\text { Padrão mais plural de PDD: Participação } \\
\text { direta e luta na decisão: }\end{array}$ & & $\begin{array}{c}\text { Tempos de } \\
\text { democratização }\end{array}$ & \multicolumn{2}{|c|}{$\begin{array}{l}\text { Tempos de Influência da política } \\
\text { neoliberal global - } \\
\text { Estabilização econômica ganha } \\
\text { relevância política }\end{array}$} \\
\hline $\begin{array}{l}\text { Atores contra-hegemônicos inseridos nas } \\
\text { instituições públicas federais. Influência } \\
\text { acentuada de fóruns/movimentos sociais. } \\
\text { Luta acirrada de interesses em torno da } \\
\text { decisão }\end{array}$ & Sarney & $\begin{array}{l}\text { I - Peso maior das } \\
\text { demandas sociais e } \\
\text { organizações sociais } \\
\text { de saúde pela } \\
\text { democratização do } \\
\text { acesso à saúde. }\end{array}$ & & \\
\hline \multirow{2}{*}{$\begin{array}{l}\text { Atores contra-hegemônicos continuam } \\
\text { inseridos no processo decisório, mas suas } \\
\text { posições não têm mais o mesmo peso na } \\
\text { decisão final. Queda da mobilização social } \\
\text { na saúde. Adoção de ações discricionárias } \\
\text { por parte do Executivo e/ou Ministério da } \\
\text { Fazenda. A estabilização econômica passa } \\
\text { a ser vista e utilizada, sobretudo em meados } \\
\text { do governo de Itamar, como principal } \\
\text { instrumento de legitimidade política. }\end{array}$} & Collor & $\begin{array}{l}\text { II - continuidade da } \\
\text { atuação política de } \\
\text { representantes do } \\
\text { mov. Sanitário o } \\
\text { nível macro. }\end{array}$ & $\begin{array}{l}\text { I - Plano ortodoxo e } \\
\text { crise de governabilidade }\end{array}$ & \multirow[t]{2}{*}{$\begin{array}{l}\text { Políticas } \\
\text { de } \\
\text { Segunda } \\
\text { geração; } \\
\text { alívio da } \\
\text { pobreza. }\end{array}$} \\
\hline & Cardoso & $\begin{array}{l}\text { IV - continuidade na } \\
\text { atuação política de } \\
\text { representantes do } \\
\text { mov. Sanitário na } \\
\text { esfera macro. }\end{array}$ & $\begin{array}{l}\text { III - peso maior da } \\
\text { influência da ortodoxia } \\
\text { econômica global: crise } \\
\text { de financiamento com } \\
\text { incremento do nível } \\
\text { básico da atenção. }\end{array}$ & \\
\hline
\end{tabular}

Esta influência gradativa do domínio da política econômica neoliberal iniciou-se no México desde o período de De la Madrid, quando houve a inserção da descentralização na agenda da política macro. Tal influência teve uma continuidade parcial no período de Salinas, dado a interrupção da descentralização, de um lado, e a adoção do Programa Solidariedade, do 
outro $^{69}$. Foi apenas nos anos de Zedillo que a estratégia de descentralização foi mais definitivamente retomada. A descentralização foi uma estratégia utilizada para promover a focalização de programas, adotados como uma forma de se ganhar eficiência na extensão focalizada do acesso à saúde. Observe que a influência do domínio da política neoliberal deuse lentamente, tendo um peso maior na política priista num tempo mais avançado da transição de regime, no contexto de fracasso das políticas públicas pretéritas (sobretudo nos anos de Salinas), em meio a um movimento social de alcance nacional (Chiapas), e após um período de regionalização da política e conseqüente decréscimo da oposição dos estados ao processo; mas ainda sem que houvesse a influência direta de grupos contra-hegemônicos de saúde na política priista. O fator determinante para o retorno da descentralização, nos anos de Zedillo, embora politicamente significativo, acabou sendo determinantemente de origem econômica (crise de dezembro), dado a natureza e interesses dos atores participantes no processo decisório, como veremos.

Quadro 3.3. O padrão restrito de participação direta na decisão macro: México; de De la Madrid a Zedillo.

\begin{tabular}{|c|c|c|c|c|c|}
\hline \multicolumn{2}{|c|}{$\begin{array}{c}\text { Padrão restrito de PDD: } \\
\text { Limitada aos atores inseridos na esfera } \\
\text { política, já articulados com a política } \\
\text { global. Não há a participação direta de } \\
\text { grupos contra-hegemônicos de saúde na } \\
\text { decisão. }\end{array}$} & \multirow{2}{*}{\begin{tabular}{l}
\multicolumn{1}{c}{\begin{tabular}{c} 
Influência \\
indireta; não- \\
determinante na \\
\multicolumn{1}{c}{ decisão }
\end{tabular}} \\
$\begin{array}{l}\text { Movimentos } \\
\text { sociais }\end{array}$
\end{tabular}} & \multirow{2}{*}{$\begin{array}{l}\text { Tempo de transição } \\
\text { de regime político } \\
\\
\text { II - reestruturação } \\
\text { econômica com } \\
\text { crise de } \\
\text { governabilidade }\end{array}$} & \multicolumn{2}{|c|}{$\begin{array}{c}\text { Tempo de Influência da } \\
\text { política econômica neoliberal }\end{array}$} \\
\hline De la Madrid & $\begin{array}{l}\text { Presidência e SPP, novo time } \\
\text { no MS, }\end{array}$ & & & I & $\begin{array}{l}\text { Políticas de primeira } \\
\text { geração: CW }\end{array}$ \\
\hline Salinas & Presidência e SEDESOL & $\begin{array}{l}\text { Movimentos } \\
\text { sociais }\end{array}$ & $\begin{array}{l}\text { III - liberalismo } \\
\text { social com } \\
\text { ortodoxia } \\
\text { econômica; crise de } \\
\text { governabilidade }\end{array}$ & II & \multirow{2}{*}{$\begin{array}{l}\text { Políticas de segunda } \\
\text { geração: alívio da } \\
\text { pobreza, regras } \\
\text { institucionais. }\end{array}$} \\
\hline Zedillo & $\begin{array}{l}\text { Presidência e SPP, consultoria } \\
\text { com o antigo time de } \\
\text { mudança do MS }\end{array}$ & $\begin{array}{l}\text { Movimentos } \\
\text { sociais (Chiapas) }\end{array}$ & $\begin{array}{l}\text { IV - peso maior da } \\
\text { influência da } \\
\text { política neoliberal }\end{array}$ & $\begin{array}{l}\text { III - } \\
\text { peso } \\
\text { maior }\end{array}$ & \\
\hline
\end{tabular}

\footnotetext{
${ }^{69}$ Isto ocorreu porque Salinas não retomou a estratégia de descentralização, interrompida antes do término do período de De la Madrid. A continuidade da influência da política global só se deu na saúde, assim como nas demais áreas sociais, com o programa solidariedade.
} 
No caso brasileiro, apesar da influência da ortodoxia econômica neoliberal (Quadro 4.1)

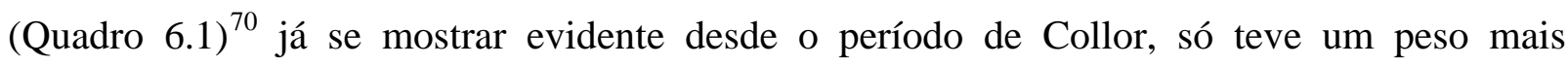
acentuado na agenda da reforma brasileira num tempo mais avançado da democratização, o qual se deu paralelamente à adoção da política de estabilização econômica e ao declínio relativo da mobilização social na saúde ${ }^{71}$. Como resultado, verificou-se o incremento das decisões discricionárias pelo Executivo, realizadas conjuntamente com o Ministério da Fazenda. A exceção se deu de forma mais acentuada, no Brasil, no primeiro estádio da redemocratização, no período de Sarney, caracterizado pela não inserção do ideário neoliberal na política e pela ampla mobilização social e política na saúde.

Considerando-se ainda a natureza distinta da própria reforma brasileira, de padrão mais plural de PDD, e articulada com a esfera da sociedade civil, não ocorreu no Brasil, como no México, a inserção, na agenda da saúde, de um programa que seguia a risca as recomendações das agências econômicas internacionais, como o Programa de Aumento da Cobertura (PAC), no México. Em vez disso, as agências econômicas internacionais financiaram um programa formulado pelo próprio movimento sanitário brasileiro e, mais especificamente, por exmembros do antigo Partido Comunista (Programa Saúde da Família, PSF) ${ }^{72}$, cuja implementação aprofundou a descentralização no setor, mas, paradoxalmente, pode ter iniciado um processo de redefinição, na realidade prática, do significado de domínio público-estatal na saúde. A concretização (ou não) desta redefinição dependerá da forma como se dará a continuidade da construção dos valores e diretrizes do SUS, em especial no que se refere aos desafios da universalidade e integralidade da atenção médica após 1998.

Outra hipótese é que o fato das recomendações da ortodoxia econômica (Quadro 4.1) (Quadro 6.1) ${ }^{73}$ influenciarem o processo decisório em tempos e seqüências distintas de transição político-econômica, indica, no caso mexicano, que a economia continuou tendo um peso determinante na redefinição do domínio público-estatal na Saúde no decorrer de toda a

\footnotetext{
${ }^{70}$ Refiro me às diretrizes basilares do federalismo fiscal, e às recomendações do Consenso de Washington e das reformas de alívio à pobreza, conhecidas como ‘reformas de segunda geração’. Estes Quadros se encontram nos Capítulos 4 e 6 respectivamente.

${ }^{71}$ Sanitaristas estarão envolvidos no trabalho de gestão nas diversas Secretarias, implementando o SUS. A década de 90 é conhecida como de menor mobilização social na saúde, comparativamente aos anos 80.

${ }^{72}$ Veja texto de Jairnilson Paim (Medicina Familiar no Brasil: movimento ideológico e ação política. Rio de Janeiro: Abrasco, Estudos de Saúde Coletiva, 4), e capítulo da tese de Flávio Goulart (2002) na bibliografia.

${ }^{73}$ Estes Quadros se encontram nos Capítulos 4 e 6 respectivamente.
} 
reforma (de 1982 a 2000). No caso brasileiro, tal fato indica que a economia, após o período de extrema mobilização social (Figueiredo e sobretudo Sarney), mais uma vez na História, mostrou-se dominante no processo de justificação e re-legitimação política do poder macro, fazendo com que as políticas de universalização do acesso à Saúde fossem, de modo semelhante aos anos de autoritarismo com desenvolvimentismo, relegadas a um segundo plano no processo decisório da política macro.

\subsection{O processo da política pública na esfera micro: identificação com a decisão da política macro?}

No que se refere ao processo da política pública (de decisão e implementação) na esfera micro, este será interpretado como processo de legitimação, por parte da política micro (articulada de forma distinta com a esfera social), dos valores e diretrizes legalizados e reivindicados como legítimos na política macro. De acordo com a teoria sobre legitimação (Weber, 1968, 1979) (Coicaud, 2003), para que os valores e diretrizes criadas na política (macro) produzam a crença em sua legalidade e, assim, se realizem e se legitimem, tornam-se necessários dois quesitos complementares de legitimidade, além da legalidade: a norma/regra criada deve 1) estar em consentimento com os valores constitutivos da identidade da sociedade, 2) sendo assim passível de realização, assumindo formas sociais e institucionais concretas. Como ressalta Coicaud, "A autoridade da lei baseia-se na crença de que sua legalidade é uma expressão dos valores da sociedade. Só quando a legalidade corresponde aos valores da sociedade, é que ela se mostra legítima. Aí existe aceitação ou consentimento” (Coicaud, 2003, p.23).

Embora envolvendo distintas formas de articulação entre legalização e consentimento (de valores e diretrizes), a legitimidade, como par conceitual da dominação, converge sempre para a questão da possibilidade (ou probabilidade) de realização concreta e, logo, de alcance dos resultados esperados (Weber, 1979, 1968) (Cohn, 1979). Isto ocorre porque a legitimidade tem seu contra-ponto na questão da manutenção do exercício da autoridade do poder, tal como reivindicada. A legitimidade revela-se, assim, em categoria que nos permite avaliar a o processo político (de decisão implementação) na esfera micro como probabilidade de submissão (aceitação) e de real concretização (obediência) das legalidades (valores e 
diretrizes) criadas e reivindicadas como legítimas pela política macro (Coicaud, 2003) ${ }^{74}$. Tratase de um conceito de caráter inter-relacional, o qual possibilita trazer à tona problemáticas especificas à reciprocidade existente, por exemplo, entre esfera social e política micro em relação à decisão política macro. Esta avaliação política requer, metodologicamente, a seleção de variáveis que nos permitam posicionar os resultados alcançados em posições distintas do contínuo aceitação-rejeição (Coicaud, 2003); ao qual a autoridade política é submetida no decorrer da execução de uma política pública.

Quadro 3.4 - Variáveis políticas micro de identificação com a decisão da política macro

\begin{tabular}{|c|c|c|}
\hline Variáveis & sub-esferas micro & Problemáticas/desafios da mudança \\
\hline Identificação do político & Política & $\begin{array}{l}\text { Relações políticas e econômicas do } \\
\text { federalismo: Autonomia política na decisão? } \\
\text { Autonomia de financiamento e no gasto? }\end{array}$ \\
\hline Identific & Adm & $\begin{array}{l}\text { Luta com o INAMPS/IMSS, problemáticas } \\
\text { relacionadas à mudança no modelo médico: } \\
\text { Universalização e integralidade na atenção? } \\
\text { Prestacão de contas e transparência? }\end{array}$ \\
\hline Identificação social & Sociedade civil & $\begin{array}{l}\text { Participação de organizações sociais na } \\
\text { decisão política e opinião do público. }\end{array}$ \\
\hline
\end{tabular}

A fim de analisarmos o processo política micro da política pública como um processo de legitimação, construímos três variáveis sócio-políticas (Quadro 3.4) que nos permitirão verificar se e em que termos as legalidades construídas no nível macro nacional, no que diz respeito às estratégias de descentralização das reformas públicas de saúde, foram executadas na realidade concreta (do processo de decisão e implementação) na esfera política micro subnacional. Trata-se 1) da identificação do político na esfera micro, 2) da identificação administrativa na esfera micro e 3) da identificação social ou da sociedade civil na esfera micro. Estas variáveis referem-se a identidades de sub-esferas distintas, porém interrelacionadas, articuladas de formas singulares na esfera política micro, e em articulação com a esfera social. O conceito de identificação vincula-se estreitamente com o de identidade, exigindo, portanto, o reconhecimento do fato que atores específicos a cada uma das sub-esferas - quais sejam, o político, o funcionário público/médico e movimentos/atores sociais inseridos

\footnotetext{
${ }^{74}$ A submissão requer a internalização de valores, e a concretização implica na externalização daqueles valores no processo de socialização. Neste, motivações subjetivas e objetivas se articulam de formas distintas e complexas. Tentaremos separar estes resultados de fundo subjetivo e objetivo da ação, do ponto de vista analítico tãosomente, por meio do uso dos conceitos de conflito e de socialização, como veremos.
} 
na política ou envolvidos no processo - já possuem, na ocasião da criação e implementação das reformas, uma identidade em relação ao domínio público-estatal na saúde, isto é: valores e interesses que se exteriorizam como formas de socialização e de luta nas esferas políticas e, mais especificamente, nas instituições de saúde, como vimos nos dois capítulos anteriores.

Esta identidade não é estática, mas transforma-se no processo de identificação e de reidentificação em relação ao significado de domínio público-estatal, na saúde, no caso. Na década de 90, os mexicanos não tinham mais a mesma percepção que tinham na década de 30 sobre a política pública de saúde do País. Os médicos, por sua vez, não atuavam em instituições idênticas a de 1930, nem adotavam exatamente as mesmas práticas. Ademais, estes atores também não tinham mais os mesmo interesses, tendo em vista as posições e status construídos e conquistados nas instituições no decorrer dos anos. A identificação implica um processo de mudança, em que a internalização de novos valores não se traduz em alternação, mas num processo lento de mudança, gerando, de modos distintos, práticas e lutas em que o novo e o velho se sobre-põem. A questão da identificação requer a investigação da possibilidade concreta de realização das diretrizes de política pública, por atores inseridos em instituições especificas a uma determinada cultura e política.

Os parâmetros selecionados para a análise daquelas três variáveis de identificação (Quadro 3.4) referem-se a algumas problemáticas centrais, as quais têm norteado o processo de construção da reforma pública de saúde no México e no Brasil. Estas problemáticas nos permitirão ressaltar, concretamente, as possibilidades de identificação da política micro com a política macro. Trata-se de problemáticas relacionadas 1) às relações políticas e econômicas do federalismo, 2) à luta com o INAMPS ou IMSS e à mudança do respectivo modelo público de atenção médica e 3) à participação social na política micro e à percepção da sociedade em relação ao política pública de saúde (Quadro 3.4).

Estas variáveis foram selecionadas com base em estudos de casos e comparados, em entrevistas realizadas nos dois países, e após o estudo dos processos de reforma nas duas sociedades (Saddi, 2002, 2003, 2003b, 2004a). Certamente as problemáticas concernentes à implementação das políticas, nos dois países, não se limitam às variáveis selecionadas, visto o grau de complexidade da realidade social e política de México e Brasil, países caracterizados pela extrema desigualdade social e regional, bem como pela adoção de estratégias e práticas diversas e inovadoras na saúde no nível local. Nosso intuito é tão-somente efetuar uma 
interpretação parcial deste processo, revelando a dinâmica dos problemas selecionados, os quais nos possibilitarão trazer à tona regularidades políticas comuns e singulares ao processo de reforma nos dois países.

A análise das problemáticas selecionadas nos permitirá determinar o nível de identificação com a política macro. $\mathrm{Na}$ análise de cada problemática, pretendemos verificar como se dá a inter-relação entre possibilidades e limites para a concretização das diretrizes/políticas no processo de mudança/implementação. A categoria luta ou conflito nos permitirá ressaltar os limites objetivos, enquanto a categoria socialização servirá para assinalar limites sócio-culturais subjetivos concernentes ao processo de legitimação do novo domínio público definido na esfera política macro. A pergunta que nos propomos na análise do processo de implementação é a seguinte: em que termos as novas políticas públicas definidas no nível macro, em cada período e país, possuem valores já tidos como públicos em cada sub-esfera da política micro, com possibilidades de internalização e realização, revelando níveis de identificação com a política macro, portanto, de legitimação da autoridade da decisão macro no nível micro?

Quadro 3.5 - Critérios para a definição dos níveis de identificação com a decisão macro

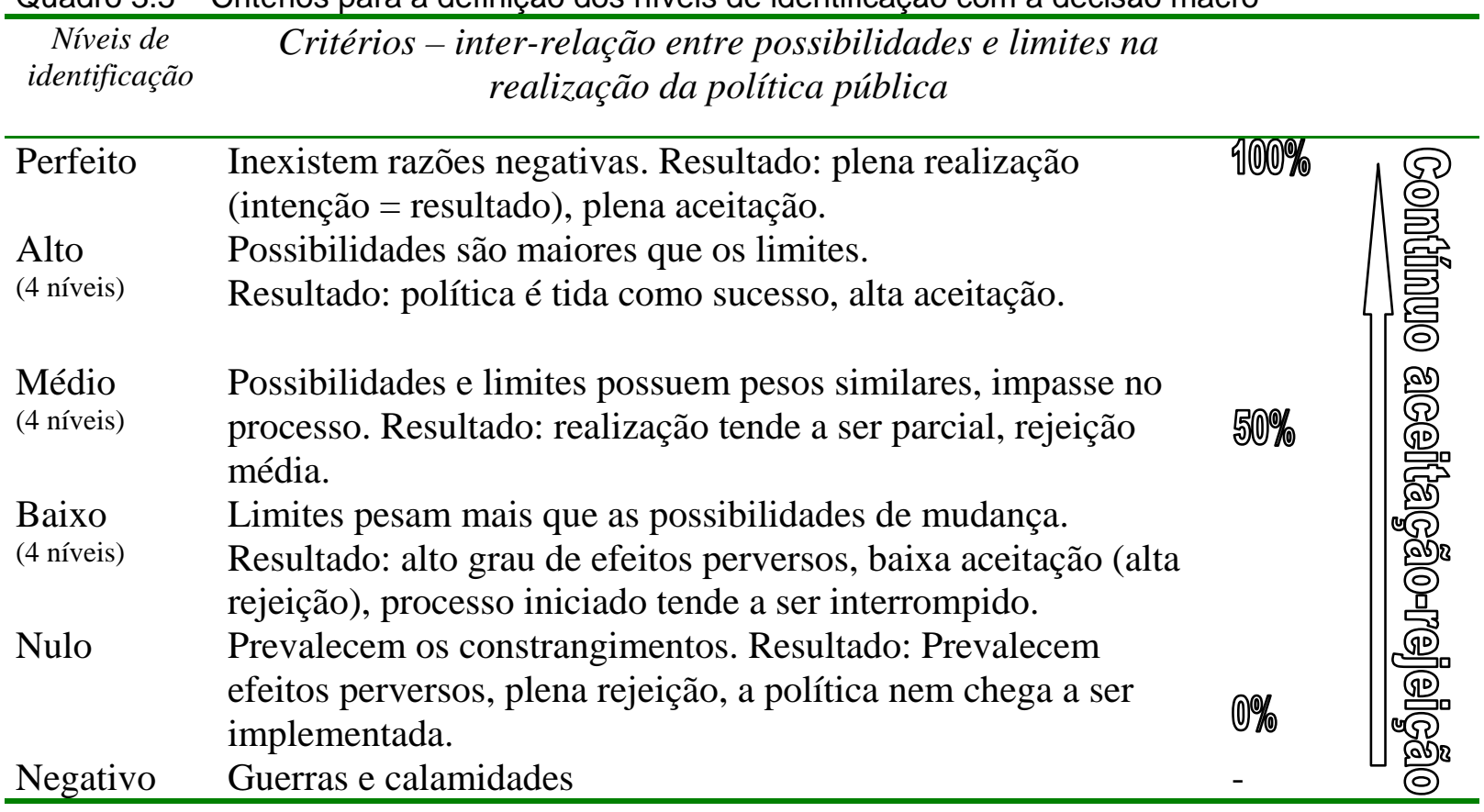


Os níveis de identificação, atribuídos de acordo com a inter-relação existente entre possibilidades e limites para a realização da política (Quadro 3.5), serão classificados como 1) perfeito, 2) alto, 3) médio, 4) baixo, 5) nulo e 6) negativo. Por estarem vinculados diretamente a possibilidades/probabilidades de realização concreta das diretrizes/normas da política pública, tendo em conta os valores e interesses dos atores e os constrangimentos institucionais específicos, estes níveis encontram-se situados dentro do contínuo aceitação-rejeição (Quadro 3.5). Nestes termos, níveis de identificação da política micro com a política macro serão utilizados como parâmetros analíticos reveladores dos níveis (coeficientes) de legitimação da política pública em construção.

\section{Identificação e legitimidade na reforma do domínio público-estatal de saúde: na perspectiva micro-macro}

Na conclusão, por fim, pretendemos trazer à tona a dinâmica sócio-política do processo de construção da reforma, estabelecendo conexões entre os processos políticos macro e micro, atribuindo à esfera política micro distintos níveis de identificação com os valores/políticas produzidos na esfera macro nacional. O intuito é utilizar estas variáveis de identificação com a política macro, a partir da perspectiva do processo político micro (decisão e implementação), como indicadores de reciprocidade, logo, de legitimidade do processo político micro em relação ao processo decisório macro. Espera-se que esses níveis de reciprocidade, a serem atribuídos a cada período da análise, e em cada país, possibilitem uma compreensão sóciopolítica mais ampla do por que das distintas dificuldades de se efetivar, na realidade concreta, os valores e diretrizes legalizadas pela política macro nacional desde 1984 no México, e desde 1988 no Brasil.

Por hipótese, o nível de identificação será maior, ou tenderá a aumentar de forma mais proporcional, quando a decisão de política pública que se pretende legitimar se traduzir na legalização de um processo que, em alguma medida, já ocorre na esfera política micro. Esta correlação direta e mais proporcional entre valores/políticas (ou princípios/diretrizes de política) decididas e implementadas tende a ser mais significativa em processos decisórios caracterizados por uma participação política mais plural, com a inserção ou influência de 
representantes da política micro sub-nacional e ou de representantes de movimentos/grupos de saúde articulados com a política micro e a esfera social.

Após termos reconstruído os processos de decisão e de implementação em cada país, e ressaltado as correlações existentes entre níveis de identificação e padrões de participação, com base na perspectiva micro-macro e no decorrer de praticamente 15 anos (Parte II e III), pretendemos, no último capítulo, efetuar uma breve análise comparada desse processo de reforma, com base na perspectiva macro-micro, focando o modo como a política macro respondeu, em distintos tempos de transição político-econômica e País, aos níveis de identificação da prática política micro sub-nacionais. Nesta análise, a questão da legitimação da política pública será relacionada à problemática da ética e da responsabilidade do ator político (Weber, 1979). Faremos, desta forma, uma avaliação sócio-política da decisão macro nacional em relação à construção política de um novo domínio público na saúde para a população aberta, e com base numa perspectiva comparada com o caso mexicano.

Vejamos então como os processos de decisão macro e de decisão e implementação micro ocorreram e se articularam em cada país, entre meados dos anos 80 e o final dos 90 . 


\section{Parte II - Decisão política e identificação na reforma pública da saúde no México: o caso da descentralização da política pública de saúde (1982-2000)}

\section{Introdução}

Esta parte da tese pretende analisar o processo de construção da reforma da saúde no México, dirigida para a população não assegurada (entre 1982 e 2000), como um processo de legitimação, o qual implicou articulações distintas entre o processo decisório e o de implementação, e, mais especificamente, entre a esfera política macro e micro. Assim como no Brasil, a descentralização se mostrará como diretriz central na redefinição da política pública de atenção à saúde. No entanto, a descentralização do domínio público-estatal não apenas apresentou natureza, formato e ritmo distintivo, em relação ao caso brasileiro, como também não consistiu uma estratégia de continuidade.

Influenciada desde o princípio pelos valores de cunho individualista da política neoliberal global, contraditórios à cultura-política mexicana, a descentralização traduziu-se, na realidade política prática, numa desconcentração político-patrimonialista, com pouca transparência e eficiência na oferta de programas focalizados. O processo de reforma foi lento, seguido de abruptas mudanças na redefinição do domínio público reivindicado como legítimo pela nova elite priista.

A pergunta central que propomos é a seguinte: de que forma, no decorrer de um processo de reestruturação econômica com lenta transição de regime político (de 1982 a 2000), os atores participantes do processo de decisão e implementação da reforma de saúde, na esfera política micro estadual, se identificaram com os valores e políticas regulamentadas e reivindicadas como legítimas pela nova elite política priista, no plano nacional, já articulada com a política global e identificada com o neoliberalismo? (Capítulo 3).

Dividimos as duas décadas em três períodos, relacionados aos últimos sexênios do Partido Revolucionário Institucional (PRI) na Presidência da República. Trata-se dos seis anos de governo de De la Madrid (1982-1988), de Salinas (1988-1994) e de Zedillo (1994-2000). Estes períodos ocorreram em tempos distintos da dupla transição política mexicana - de reestruturação econômica e de lenta mudança no regime político -, caracterizados por um alto 
nível de incerteza econômica e de instabilidade política. A incerteza econômica deveu-se às contínuas crises econômicas, sem precedentes na História do país, as quais colocaram em cheque a capacidade dos governos priistas administrarem a economia. A instabilidade política, por sua vez, relacionou-se às possibilidades de continuidade do PRI no poder (macro e micro estadual), em meio ao surgimento de diferentes atores políticos, os quais tiveram seus papéis (re)definidos no país. Foi em meio a estes contextos de dupla transição política que, a cada sexênio, vieram à tona problemáticas concernentes à legitimação da autoridade do domínio público na saúde, as quais obrigavam a política macro a propor mudanças e/ou bruscas interrupções na política pública anteriormente em construção.

\section{Questões e hipóteses: o padrão restrito de participação na decisão (PDD) e a estratégia de descentralização da política pública de saúde no México}

As situações de crises econômicas e político-sociais, vindas à tona a cada início de sexênio, mostraram-se como fatores explicativos das mudanças realizadas na redefinição da extensão e escopo do significado de “público”, no que se refere à política pública de saúde para a população aberta. As conjunturas de crises se apresentaram como uma estrutura de escolhas com base na qual os atores dominantes inseridos na esfera política macro, quais sejam, o novo presidente e seu grupo, já identificados com o neoliberalismo e em aliança com a política global, tiveram que tomar decisões concernentes à redefinição da política pública de atenção à saúde, para a população aberta. Vejamos algumas questões e hipóteses relacionadas à construção da decisão e da implementação na reforma mexicana.

\subsection{Sobre a decisão política de reformar o domínio público-estatal na Saúde}

As primeiras questões que surgem na análise do caso mexicano referem-se ao por que da redefinição no significado (natureza, extensão e escopo) do domínio público-estatal na saúde em cada período: Por que De la Madrid direcionou a reforma da saúde para a descentralização, num contexto político ainda marcado pela centralização política e dependência econômica (em relação ao governo federal) e, logo, adverso à descentralização? Por que Salinas, no sexênio seguinte, não deu continuidade à estratégia de descentralização e direcionou sua política para um novo programa social: o Programa Nacional de Solidariedade (PRONASOL)? Por que, diferentemente de Salinas, foi politicamente possível a Zedillo 
retomar o processo de descentralização da saúde junto a todos os estados, só que de forma mais aprofundada que De la Madrid?

A nossa hipótese, no que se refere à elaboração das reformas e/ou descentralização, é que os projetos de política pública de saúde foram condicionados, nas distintas fases da dupla transição política, pela forma como a nova elite governante priista (que assumiu a presidência a partir de 1982), já articulada com a política global, em meio às crises econômicas e às manifestações ou potencialidade de reivindicações da sociedade civil e/ou dos partidos de esquerda e de centro esquerda, passou a responder a diferentes pressões. A permanência de um Estado de matriz-cêntrica de poder (Capítulo 2), já num contexto de articulação com a política global - e de conseqüente ausência de movimentos contra-hegemônicos de saúde no processo decisório -, somados aos fracassos anteriores na implementação das reformas, deram condições políticas para que Salinas rompesse com a política de saúde anterior, e para que Zedillo rompesse com PRONASOL, retomando a descentralização, já num tempo mais avançado da transição/regionalização política, e seguindo de forma mais direta as recomendações do Banco Mundial para o setor saúde.

Em todo o período da reforma (1982-2000) o incremento das pressões de tipo neoliberal, sobre a decisão política macro, se deu dentro de um padrão restrito de participação no processo decisório (Quadro 3.3). De forma gradual e contínua, o autoritarismo-conservador da política priista associou-se, no decorrer do tempo (de 1982 a 2000), ao novo conservadorismo político global, de caráter neoliberal. Outra hipótese é que esta gradual e contínua inserção das recomendações globais para a saúde deveu-se ao caráter contraditório inerente ao processo de legitimação da política priista que, de um lado, sempre procurou atender mais explicitamente os interesses inseridos em aliança direta com o poder e, de outro, procurou, indiretamente, atender os interesses da sociedade em geral. Esta gradual inserção das recomendações de tipo neoliberal, na agenda da política macro, também foi influenciada pelos baixos níveis de identificação da política micro, com a política pública (legislações; valores e diretrizes) reivindicada como legítima pela política macro.

\subsection{Sobre a identificação no processo político micro (decisão e implementação)}

No que se refere ao processo político micro estadual, diferenciou-se nos três períodos o formato e ritmo da descentralização/regionalização da política de saúde naquelas situações. Ao 
longo de duas décadas, a descentralização traduziu-se num processo de desconcentração e de ritmo lento e descontínuo: teve um começo incipiente, seguido de uma parada e posterior retomada. Com efeito, após 18 anos desde o início da descentralização da política pública de saúde, o domínio público-estatal de saúde da SSA continuava imerso no centralismo, em detrimento da autonomia política e, sobretudo, financeira dos estados no gerenciamento de seus sistemas de saúde. A pergunta que nos propomos é a seguinte: Por que o México implementou a política de descentralização em apenas 14 estados nos anos de De La Madrid, estagnou esse processo nos anos de Carlos Salinas (mas promoveu uma estratégia de regionalização da política social) e tão-somente adotou uma política de descentralização mais ampla (firmando acordos com todos os estados), no entanto ainda política e economicamente centralizada, apenas nos anos de Zedillo?

Neste trabalho, o porquê do ritmo lento na concretização da mudança, assim como a permanência do caráter centralizado da descentralização, será buscado na forma como os políticos regionais (sobretudo governadores), os atores das instituições públicas tradicionais (de assistência à saúde, SSA e IMSS) e grupos/movimentos sociais reagiram, em distintos tempos de dupla transição, no decorrer do processo de decisão e implementação das políticas reivindicadas como legítimas pelo governo federal.

A nossa hipótese é que o ritmo parada com mudança e retorno, assim como o caráter singular do formato menos centralizado da política pública, podem ser atribuídos ao baixo nível de identificação (política, administrativa e social) da política micro e, logo, de realização das políticas públicas reivindicadas como legítimas pela política macro. Este baixo nível revela que mais uma vez, na Historia social mexicana, as iniciativas políticas para a população aberta mostraram-se socialmente perversas ou paradoxais em termos de resultado.

No decorrer do processo de 18 anos como os níveis de identificação da política micro foram demasiadamente baixos, em especial quando comparados com os níveis pouco mais elevados de identificação, mas ainda críticos, da reforma brasileira (Capitulo 5). A nossa hipótese é que apesar de ter ocorrido um deslocamento mais significativo no contínuo aceitação-rejeição nos anos de Zedillo - sobretudo quando comparado com o acentuado fracasso da política de De la Madrid e com os escândalos e fracassos do programa de Salinas -, a descentralização zedillista compreendeu apenas o primeiro tempo de viabilidade política da descentralização. Tratou-se de uma viabilidade de tipo não-participativo (Quadro 3.3), de 
caráter autoritário-neoconservador, em que a autoridade do domínio público reivindicado como legítimo se posicionava apenas num estádio inicial de legitimação do processo em construção. Entre 1994 e 2000, o nível de identificação deslocou-se do intervalo Nulo-Baixo2 (no qual oscilou desde de La Madrid) para um patamar mais alto dentro do próprio nível baixo (Baixo4); por isto ainda não consistiu em alta aceitação da política pública (Leis; valores e diretrizes) decididos na política macro priista, apenas numa rejeição mais baixa.

Ressaltadas as questões e hipóteses que guiarão a análise do caso mexicano, vejamos como se deu a construção da decisão e da implementação da descentralização/regionalização da política pública de saúde nos três últimos sexênios do PRI na Presidência do México. Para, em seguida, tecermos algumas considerações finais sobre a dinâmica deste processo, com base na perspectiva micro-macro. 


\title{
Capítulo 4 - Reforma da política pública de saúde e crise de governabilidade política: a primeira etapa da descentralização da política pública de saúde no governo de De la Madrid (1982 a 1988)
}

\begin{abstract}
"O novo marco jurídico de saúde e a estratégia de introduzir mudanças estruturais no sistema econômico e social, no qual se baseia o Plano Nacional de Desenvolvimento, foram necessárias para que se consolide um sistema nacional de saúde, formado pelas dependências e entidades públicas que prestam serviços de saúde e pelos setores sociais e privados, que, coordenados pela Secretaria de Salubridade e Assistência, resultará no incremento e no uso mais eficiente dos recursos para ampliar a cobertura e elevar a qualidade dos serviços"

(Poder Ejecutivo Federal, PNS, 1984, p. vii).
\end{abstract}

De la Madrid assumiu a presidência do México em dezembro de 1982, quando se evidenciava uma queda drástica no PIB e um acréscimo histórico na inflação e na dívida do setor público. $\mathrm{O}$ ano terminava com uma variação de $-0,5 \%$ no PIB trimestral, contrastando com o percentual de 8,5\% (INEGI, 2003) ${ }^{75}$ do último trimestre de 1981. A inflação média anual chegava a 43,03, a cima da média de 28,01 referente a 1981 (INEGI, 2003). A dívida líquida total do setor púbico compreendia 52,3\% do PIB. A nova facção do PRI assumia o controle do país em um clima de incerteza econômica ainda não presenciado na História mexicana ${ }^{76}$. Esta incerteza se traduzia em desafio político a ser enfrentado pela nova elite governamental, num contexto em que a liberalização política iniciada por Portillo, mesmo que ainda em período inicial, havia institucionalizado a participação da sociedade civil, em ampla mobilização desde o massacre estudantil de 1968. O desafio econômico adicionava-se ao político-social, e traduzia-se em desafio político a ser enfrentado por meio da elaboração de novas políticas públicas, extensivas a um maior numero de mexicanos. Foi em meio a este contexto de instabilidade política que o novo governo apresentou uma nova solução para as políticas públicas mexicanas. Tratava-se do caminho das reformas estruturais, realizadas em

\footnotetext{
75 Indicadores econômicos calculados com base em séries de dados de 1980 a 2003. Fonte: INEGI (Instituto Nacional de Estadística, Geografía e Informática), Indicadores Económicos de Coyuntura de 1980 a 2003. www.inegi.gob.mx , acesso em maio de 2003.

${ }^{76}$ Para uma melhor compreensão do caráter político da crise econômica instaurada consulte os trabalhos de Wayne Cornelius (The political economy of Mexico under De la Madrid: The Crisis Deepens, 1985-1986. Research Report Series 43. La Jolla, Center for US-Mexican Studies, University of Califórnia, 1986) e de Blanca Heredia ("Estructura política e reforma económica: el caso de México”, In: Mayer-Serra \& Hernández (comp.) Lecturas sobre el cambio político en México (2002). México, DF, Fondo de Cultura Económica.
} 
cada setor, mas subordinadas à reforma estrutural da economia (Poder Ejecutivo Federal, PND, 1983).

\section{A decisão não-participativa pela redefinição no domínio público-estatal na saúde: autoritarismo e neoconservadorismo}

Como vimos, as linhas mestras do projeto de reforma da política pública de saúde já haviam sido elaboradas nos últimos anos do governo de Portillo, por meio da contratação da consultoria de Dr. Soberón. Este foi designado por De la Madrid para o posto de Secretário da SSA e, assim, tornou-se o responsável direto pela articulação política necessária para a implementação da reforma estrutural da saúde. Como ressalta Leal (2000) (2002), a indicação de Dr. Soberón consistiu uma ruptura no padrão de nomeação dos secretários de saúde no México. Dr. Soberón não pertencia ao tradicional grupo de sanitaristas do PRI. Pela primeira vez o governo federal não havia nomeado um clínico para o setor, para quem o exercício da medicina social relacionava-se mais diretamente a questões epidemiológicas. Em seu lugar, a nomeação foi dada para um pesquisador da área biomédica, com tradição em pesquisa laboratorial e, logo, com o interesse voltado para a incorporação das ciências básicas (Leal, 2000) (Leal, 2002). Esta mudança de perfil do secretário de saúde respondia aos interesses da nova elite governamental. Queriam dar uma resposta nova e imediata aos problemas evidenciados pelo "modelo médico corporativo" de matriz cêntrica. O grupo de Soberón apresentou uma proposta sobre como descentralizar esse sistema, conciliando a questão da duplicidade de gasto com a da extensão da cobertura de serviços para a população aberta. “A estratégia de descentralização dos serviços de saúde incluída neste trabalho (o de consultoria) foi o pivô para a implementação das outras estratégias (setorização, modernização da SSA, coordenação intersetorial e participação comunitária), pois a descentralização da vida nacional foi um dos princípios básicos do programa de governo de Miguel de la Madrid, postulados desde sua campanha política” (Soberón-Acevedo \& Martínez-Narvaéz, p.03).

Ressalta-se assim que a decisão pela descentralização da política pública partiu “de cima”, da própria esfera de poder. Seguiu um padrão autoritário, já de cunho neoconservador, visto que a decisão pela mudança no domínio público-estatal surgiu do próprio grupo da SPP, agora na Presidência do país, e com a participação exclusiva do grupo que se formaria como o principal think-tank de economia de saúde no México, qual seja, a Fundação Méxicana para a Saúde (FUNSALUD). De forma politicamente significativa, os valores e estratégias 
concernentes à redefinição da política pública, decididos pela nova elite priista, e sem a influência ou participação direta de grupos contra-hegemônicos de saúde e de representantes da política estadual, já apresentavam uma alta afinidade eletiva com os micro-fundamentos de domínio da política econômica e, mais especificamente, com as recomendações do Banco Mundial para o setor.

A partir dos anos 80 o Banco Mundial acentuou sua importância política estratégica na gestão do endividamento e reestruturação econômica dos países em desenvolvimento. Em virtude das condicionalidades ${ }^{77}$ de empréstimos e das recomendações impostas, essa instituição também passou a exercer amplo controle sobre o conjunto das políticas públicas domésticas. Embora em tempos e formas distintas entre os países, as reformas setoriais, como as da saúde, foram condicionadas pelas políticas de ajuste estrutural do chamado Consenso de Washington $^{78}$. Tratava-se de um consenso político economicamente determinante, o qual caracterizou a atuação da política global da nova direita hegemônica, até início dos anos 90.

No caso mexicano, a decisão pela reforma no domínio público-estatal objetivava conciliar as necessidades da administração da economia com a premência da legitimação do novo PRI perante a sociedade civil, por meio de amplas reformas setoriais, como a de saúde.

Dentre as redefinições efetuadas no público-estatal da saúde destacavam-se: 1) a reforma administrativa do setor 2) “a renovação legislativa” e 3) a principal “reforma substantiva"79: a descentralização. No primeiro ano do governo, a atuação da SSA mostrou-se voltada para a concretização das duas primeiras estratégias assinaladas, as quais foram qualificadas como "ações programáticas" que deveriam possibilitar os mecanismos administrativos e jurídicos necessários para implementação da descentralização. Esta, por sua vez, corresponderia à etapa de “integração orgânica” da política público que se reivindicava

\footnotetext{
77 O Banco só expande seus projetos na medida em que o país se mostre capaz de fornecer fundos de contrapartida. Como resultado, as ações do Banco acabam se mostrando estreitamente dependentes da vigência dos acordos com o FMI. Veja relatos da experiência de Stiglitz em A globalização e seus malefícios.

${ }^{78}$ O Consenso de Washington possui dez objetivos principais: 1) disciplina fiscal, 2) redirecionamento do gasto público para investimentos com saúde, educação e infra-estrutura, 3) reforma tributária, 4) taxas de juros positivas determinadas pelo mercado em termos reais, 5) taxas de câmbio competitivas, 6) liberalização comercial, 7) abertura ao investimento estrangeiro direto, 8) privatização de empresas públicas, 9) desregulação - abolir as regulações que impedem a entrada da competição, 10) segurança legal aos direitos de propriedade.

${ }^{79}$ A reforma substantiva incluiu dez estratégias, cinco de nível macro e cinco de nível micro. As primeiras foram a descentralização, a setorização institucional, a modernização da SSA, a coordenação intersetorial e a participação comunitária. As estratégias de nível micro constituíram a investigação em saúde, o desenvolvimento dos recursos humanos, a informação em saúde, o financiamento e insumos do SNS (Soberón, entrevista 2003).
} 
coma legítima, uma vez que implicaria na integração dos serviços de saúde a cargo da SSA e do IMSS-COPLAMAR, transferindo-os para os recém criados Sistemas Estatais de Saúde (SESAs).

Por meio das duas ações programáticas, os princípios da nova administração pública e dos micro-fundamentos da economia foram inseridos na agenda da saúde. A reforma administrativa baseava-se nos princípios de organização administrativa e cooperação da teoria anglo-saxônica de administração pública; de acordo com a qual uma organização ou instituição visa à cooperação entre indivíduos.

Quadro 4.1. O federalismo fiscal: descentralizar com eficiência econômica

O objetivo principal da literatura tradicional de federalismo fiscal é definir critérios de eficiência econômica para as políticas públicas em sistemas federativos. Este ramo das finanças públicas preocupase em discutir como deve ocorrer a competência de gasto, a responsabilidade de tributação e o desenho das transferências inter-governamentais numa federação.

Tanto a teoria como as experiências de déficit público ressaltam que a questão da responsabilidade sobre os gastos mostra-se essencial, em especial no que se refere ao incremento da capacidade do governo prestar contas. No planejamento da descentralização, cabe ao governo central definir as regras de alocação e gasto de recursos em âmbito nacional e, ao governo sub-nacional, planejar e decidir a alocação de gastos de acordo com os parâmetros definidos pelo centro. Sustenta-se que estes parâmetros devem ser consistentes com critérios de eficiência econômica, segundo o qual os gastos não devem superar a receita.

Em alguns setores, as funções devem ser compartilhadas, visto que os níveis mais altos de governo exercem um papel regulatório, enquanto os níveis mais baixos se mostram responsáveis pela oferta de serviços. "A chave para uma boa política pública é o claro entendimento dos resultados que são importantes para o governo federal e governos locais. O governo federal deve manter controle (por meio da provisão direta ou criação de incentivos para os governos locais) sobre funções cujos resultados são considerados importantes para ele, e deve renunciar ao controle de funções para as quais não existem divergências nos governos locais sobre suas prioridades” (Litvack, Ahmad, Bird, 1998, p. 11).

Com base em Musgrave, Oates (1972) apresenta algumas linhas gerais para a definição de instrumentos de competência de arrecadação entre os diferentes níveis de governo. Para o autor, os impostos altamente progressivos, especialmente aqueles com propósitos distributivos, devem ser centralizados. Os níveis mais baixos de governo não devem ter impostos sobre bases móveis. O governo central deve exercer autoridade primária sobre bases que são distribuídas de forma desigual entre jurisdições (recursos naturais). Já os tributos de usuários e taxas devem ficar no nível mais baixo.

Considera-se essencial nivelar o nível de gastos ao de receitas. Ao descentralizar mais receitas que gastos, o Governo Federal pode se encontrar privado de recursos necessários para atingir suas obrigações. De forma contrária, a descentralização de gastos sem recursos adequados pode ocasionar a privação de recursos no nível subnacional (Shah, 1999). Daí por que deve haver um planejamento e controle em relação à responsabilidade de gastos e, de forma semelhante, um projeto claro de divisão de competências tributárias entre os níveis governamentais.

Em relação à problemática das transferências inter-governamentais, Oates (1972) afirma que as transferências têm sido usadas em Federações para combater o déficit de cada unidade governamental. Essas transferências podem ser vinculadas ou incondicionais. As vinculadas visam à provisão de algum bem ou serviço pré-estabelecido. Já as incondicionais, consistem em transferências que objetivam promover uma redistribuição de renda entre os governos. O Governo Federal deve, assim, transferir recursos para garantir a habilidade do governo local em assumir responsabilidades, adotar requisitos mínimos para gasto com manutenção e treinamento para garantir a qualidade e sustentabilidade do serviço publico designado. 
A reforma legislativa, por sua vez, alterava os fundamentos constitucionais para o setor saúde. Esta deixaria de ser definida como um direito social, como constava na Constituição desde 1917, passando a configurar-se como um direito individual, aplicado especificamente à atenção médica. Além do caráter individualista atribuído ao direito público, a nova legislação também se basearia nos princípios do federalismo fiscal ou Economia do setor público (Quadro 4.1), os quais têm por fim a alocação eficiente dos recursos públicos empregados. De modo que as diretrizes estratégicas do novo domínio público, reivindicado como legítimo pela esfera política macro, não faziam parte da cultura-política e das formas de socialização praticadas por décadas nas instituições de saúde, quais sejam: centralismo fiscal e decisório, não prestação de contas, clientelismo e corrupção (Capítulo 1).

Estas estratégias propunham, a partir do poder e de forma não-participativa (Quadro 3.3), uma nova identidade para o domínio público-estatal, contrariando diretamente os valore/interesses e práticas dos principais atores do setor saúde. Com efeito, a realização dessas estratégias - programáticas e de integração - exigiria uma coordenação que nunca havia existido entre as instituições cabeças do sistema de saúde (IMSS e SSA). Ademais, pretendiase alterar a competência das entidades federativas ainda no marco de uma estrutura fiscal (de receita) centralizada no governo federal e dentro de um tempo inicial de uma lenta distensão política.

Tendo em vista a extrema divergência existente entre os valores e interesses que nortearam as decisões produzidas na esfera política macro, de um lado, e os valores e interesses que têm orientado a cultura-política mexicana, tal reforma reivindicava uma "alternância" idealizada politicamente, pela política macro priista, a qual se mostrava praticamente impossível de ser legitimada na realidade política da esfera política micro estadual. A realização dessa estratégia autoritária e de tipo não-participativo (Quadro 3.3) iria requerer um nível extremado de negociação política por parte da chefia da SSA com o IMSS, de um lado, e com governadores, de outro, como veremos. 


\subsection{Decisão autoritária e mudança no sub-setor público-estatal da SSA}

A reforma administrativa consistiu na elaboração de um novo estatuto legal para o setor público de saúde. Alterava-se o nome da antiga Secretaria de Salubridade e Assistência para Secretaria de Saúde (SSA), e instituia-se um Sistema Nacional de Saúde (SNS), o qual integrava as instituições de seguridade social e as instituições de saúde pública direcionadas à população não-assegurada. De acordo com a nova legislação, A Secretaria de Saúde deixava de ter a função de assistência para assumir a direção e coordenação de todo o sistema de saúde, com poder sobre as coordenações estaduais e as instituições de seguridade social inclusive. Pretendia-se, assim, modificar a posição e papel dos principais prestadores de serviços públicos de saúde no país.

Instituída legalmente pela nova política priista como coordenadora do sistema, a SSA deu início a um processo de reivindicação do seu novo poder de comando, participando das reuniões dos Conselhos de Governo das instituições de seguridade social. No entanto, tal reivindicação não foi reconhecida como legítima, isto é, não foi aceita e realizada no decorrer de sua implementação. García Sáinz, diretor do IMSS, negou na prática política qualquer possibilidade de participação do secretário no Conselho Técnico do Instituto, e foi preciso a intervenção do Presidente da República para que Soberón pudesse participar do Conselho Técnico do IMSS. Contudo, note que Soberón foi incluído apenas como um membro a mais do grupo de 12 representantes tripartides do Conselho, os quais permaneceram sob o comando da direção do Instituto ${ }^{80}$. As primeiras reuniões do Conselho do IMSS foram marcadas por conflitos, em especial no que se refere à questão da transferência do IMSS-COPLAMAR para a SSA. Devido a estes $\operatorname{conflitos}^{81}$, “o Conselho Técnico optou por isolar o secretário deste corpo decisório. Desde então a agenda das reuniões foi preenchida por assuntos triviais” (González-Block, p.193). Ao perceber a situação, Soberón deixou de participar de tais reuniões, enviando seu subsecretário de planejamento. Como resultado, a tentativa de integração do sistema de saúde, cujo alvo final era a descentralização, mostrou-se fracassada desde seu início.

\footnotetext{
${ }^{80}$ Já no ISSSTE a situação era outra, Soberón foi nomeado como presidente do Conselho Técnico desse Instituto.

${ }^{81}$ Para detalhes sobre estes conflitos, veja o capítulo VII da tese de González-Block, indicada na bibliografia.
} 


\subsection{A inserção legal de valores de mercado no público mexicano}

No que se refere à “renovação legislativa”, esta foi iniciada em 1983 com a modificação do artigo $4^{0}$ da Constituição, colocando a proteção à saúde como direito individual e responsabilidade do Estado. Esta legislação não foi fruto de uma negociação política no Congresso Nacional, como na democratização brasileira. A nova lei foi elaborada pela equipe de Soberón e instituída por Decreto Presidencial e ratificada pelo Congresso priista. Esta mudança se traduziu em instrumento político, de cunho normativo, por meio do qual a nova coalizão política contraditoriamente reiterou seu compromisso com a Constituição de 1917 e, portanto, com o amplo pacto social resultante da Revolução Mexicana. De forma semelhante a 1917, o meio normativo mais uma vez se converteu em instrumento de legitimação do Estado perante toda a sociedade. No entanto, continuava-se utilizando mecanismos autoritários de representação para modificar o fundamento constitucional do próprio direito na nova legislação. A nova Lei instituía a saúde não mais como direito social de todos, este direito assumia um caráter individual, condicionado ao nível de renda do indivíduo (Quadro 4.2).

Quadro 4.2 Lei Geral de Saúde de 1984: as bases da reforma

TITULO SEGUNDO - Sistema Nacional de Salud

Artículo 7: La coordinación del Sistema Nacional de Salud estará a cargo de la Secretaría de Salud

CAPITULO II - Distribución de competencias

Artículo 13: La competencia entre la Federación y las entidades federativas en materia de salubridad general quedará distribuida conforme a lo siguiente:

A. Corresponde al Ejecutivo Federal, por conducto de la Secretaría de Salud:

I. Dictar las normas oficiales mexicanas a que quedará sujeta la prestación, en todo el territorio nacional, de servicios de salud en las materias de salubridad general y verificar su cumplimiento

Artículo 20: Las estructuras administrativas se ajustarán a las siguientes bases;

II. Se establecerán coordinadamente entre la Federación, por conducto de la Secretaría de Salud, y los gobiernos de las entidades federativas;

III. Podrán tener personalidad jurídica y patrimonio propios y funciones de autoridad, en su caso, de conformidad con los instrumentos legales de creación;

VI. Tendrán a su cargo la administración de los recursos que aporten las partes, con sujeción al régimen legal que les corresponda;

VII. Promoverán y vigilarán la aplicación de principios, normas oficiales mexicanas y procedimientos uniformes;

VIII. Tendrán participación representantes de los usuarios, así como de los trabajadores al servicio de éstas

estructuras, en los términos de las disposiciones que al efecto se expidan, y

IX. Las demás que se incluyan en los acuerdos de coordinación que se celebren.

CAPITULO II y III - Atención médica y Prestación de los Servicios de Salud

Artículo 32: Se entiende por atención médica el conjunto de servicios que se proporcionan al individuo, con el fin de proteger, promover y restaurar su salud.

nes tendientes a corregir las invalideces físicas o mentales.

Artículo 34: Para los efectos de esta Ley, los servicios de salud, atendiendo a los prestadores de los mismos, se clasifican en:

I. Servicios públicos a la población en general;

II. Servicios a derechohabientes de instituciones públicas de seguridad social o los que con sus propios recursos o por encargo del Poder Ejecutivo Federal, presten las mismas instituciones a otros grupos de usuarios;

III. Servicios sociales y privados, sea cual fuere la forma en que se contraten, y

IV. Otros que se presten de conformidad con lo que establezca la autoridad sanitaria.

Artículo 35: Son servicios públicos a la población en general los que se presten en establecimientos públicos de salud a los habitantes del país que así lo requieran, regidos por criterios de universalidad y de gratuidad fundada en las 
condiciones socioeconómicas de los usuarios.

CAPITULO IV - Usuarios de los servicios de salud y participación de la comunidad

Artículo 59: Las dependencias y entidades del sector salud y los gobiernos de las entidades federativas, promoverán y apoyarán la constitución de grupos, asociaciones y demás instituciones que tengan por objeto participar organizadamente en los programas de promoción y mejoramiento de la salud individual o colectiva, así como en los de prevención de enfermedades y accidentes, y de prevención de invalidez y de rehabilitación de inválidos.

Artículo 60: Se concede acción popular para denunciar ante las autoridades sanitarias todo hecho, acto u omisión que represente un riesgo o provoque un daño a la salud de la población.

La acción popular podrá ejercitarse por cualquier persona, bastando para darle curso el señalamiento de los datos que permitan localizar la causa del riesgo.

Fonte: Ley General de Salud, In: http://www.salud.gob.mx/unidades/dgaj/ acesso em 05 de maio de 2004.

A chamada "cascata legislativa” preparada pela equipe de Soberón (Soberón-Acevedo, entrevista, 2003) foi complementada com a promulgação da Lei Geral de Saúde (LGS) em 1984, que, em seu artigo $21^{\circ}$ (do Capítulo II), e nos capítulos respectivos a cada diretriz, estabeleceu de forma genérica as bases para a mudança na atenção médica, dentre as quais destacavam-se as seguintes estratégias: 1) Formação de um sistema nacional de saúde coordenado pela SSA; 2) descentralizado, com distribuição de competências entre as unidades federativas; 3) e com participação da comunidade, como assinalado no Quadro 4.2.

De acordo com a LGS, os critérios de transferência de recursos federais para os estados descentralizados deveriam ser acordados individualmente, com cada entidade federativa, por meio da formalização de convênios entre a SSA e governos estaduais. Estes acordos de financiamento, como ressalta Leal, "buscaram promover os recursos estatais, juntamente com os recursos federais segundo as possibilidades de cada entidade. De outro lado, as transferências se realizariam diretamente para os serviços de saúde. Com isto procurou-se facilitar a gestão, isto é, a possibilidade de efetuar transferências de recursos conforme as necessidades" (Leal, 2002, p.92). Contraditoriamente, mas de forma politicamente significativa, a inserção autoritária da descentralização na agenda da reforma do domínio público-estatal iria seguir os critérios informais de negociação, os quais têm permeado as relações políticas no México. Garantia-se assim a continuidade de dependência das entidades federativas do orçamento federal, mediante negociações políticas individuais.

Estes dois grupos de propostas - a reforma administrativa e a renovação legislativa ocorreram até o início de 1984, preparando o caminho para a implementação da principal "estratégia substantiva" do setor: a descentralização. 


\section{O processo de "descentralização" em 14 estados}

A descentralização foi iniciada apenas em 1985, e em nove estados (Nuevo León, Guerrero, Baja California Sur, Morelos, Tabasco, Jalisco, Querétaro, Sonora e Tlaxcala). Em março de 1986 outros três estados assumiam a responsabilidade dos serviços (Colima, Guanajuato e México) e no final de 1987 mais dois estados foram incluídos na descentralização (Aguascalientes e Quintana Roo). Por que apenas 14 estados foram inseridos na etapa de integração orgânica, com a criação das SESAs (sistemas estatais de saúde), que deveriam assumir a responsabilidade do IMSS-COPLAMAR?

Os obstáculos para a implementação da descentralização, bem como as problemáticas derivadas da mesma, foram colocados pela tensão existente entre as estratégias decididas na política macro, de um lado, e os valores e interesses que guiaram a implementação da reforma nas esferas políticas micro estadual, de outro. Vejamos em que termos a atuação dos principais atores do setor - quais sejam, da cúpula do IMSS, do pessoal do IMSS-Coplamar e dos governadores -, revelaram o baixo nível de identificação da política micro com a reforma macro.

\subsection{A não identificação da administração pública}

O baixo nível de identificação da administração pública com a política macro pode ser ressaltado pela política de sabotagem do IMSS realizou-se em três frentes. A primeira consistiu no não reconhecimento da SSA como coordenadora do sistema público de saúde, levando ao bloqueio da participação de Soberón primeiramente como presidente e, em seguida, como integrante nas decisões centrais no Conselho Técnico do IMSS, como vimos. A segunda frente constituiu a política de difamação da estratégia de descentralização junto aos governadores. O IMSS “desqualificou perante aos governadores a capacidade da SSA para receber o programa de solidariedade social (...) O IMSS argumentou que os Serviços Coordenados careciam de infraestrutura administrativa necessária para assimilar seu vasto programa, o que implicaria irremediavelmente seu deterioro ao nível ínfimo dos serviços da Secretaria” (González-Block, p.203). Além disso, "O diretor do seguro social conversava diretamente com os governadores para eles se esquivarem, não entrarem na descentralização" (Soberón-Acevedo, entrevista, 2003). A terceira frente de sabotagem, por fim, se deu mais diretamente com o pessoal do IMSS-COPLAMAR nos estados. Dado os conflitos que já estavam ocorrendo com a chefia do 
IMSS, e com a oposição do sindicato do próprio Instituto, Soberón foi obrigado a ver como se encontrava a situação nas regionais. "Chamei o pessoal e perguntei: querem continuar trabalhando sob o seguro social ou sob a SSA? Muitos retornaram para o seguro social, sobretudo para as cabeças. E me deixaram os serviços de IMSS-Coplamar descabeçados. Houve muitos desajustes. O funcionamento não estava igual. Esta foi a sabotagem” (SoberónAcevedo, entrevista 2003).

\subsection{A não identificação do político}

No que se refere ao nível baixo de identificação do político (com os valores e interesses macro), de forma quase unânime os governadores não tinham interesse em assumir a responsabilidade de assistência à saúde. Esta recusa dos governadores deveu-se a algumas razões. A necessidade de se efetuar um compromisso financeiro com o setor saúde mostrava-se como um dos motivos da recusa, uma vez que os estados deveriam realocar parte do seu orçamento para a saúde. O orçamento federal enviado para os estados deveria ser utilizado exatamente conforme previsto nos convênios. Os estados não podiam criar vagas de trabalho, também não tinham liberdade para comprar equipamento médico, medicamento, ou para construir. Só havia liberdade para decidir programas de “maternidade”. Mesmo assim, era necessário enviar o projeto para o nível federal, para ter autorização, a menos que se fizesse com o orçamento estatal. A falta de capacidade técnica e as limitações da infraestrutura hospitalar e administrativa compreendiam outras razões para os governos se oporem à descentralização. Ademais, existiam nos estados trabalhadores federais e federalizados. Estes recebiam do governo estadual, enquanto aqueles recebiam do governo federal possuindo um maior nível salarial. Daí o porquê da oposição da Federação de Sindicatos de Trabalhadores dos Serviços do Estado (FSTSE). A negativa dos governos locais a estatizar (nacionalizar) o pessoal dos serviços de saúde devia-se não apenas às repercussões políticas com sindicatos, como também econômicas que poderia trazer para os estados. De forma que estes motivos todos, somados à política de difamação comandada pelo IMSS junto aos governadores, além de terem norteado o processo de negociação dos convênios e de criação das SESAs nos 14 estados, nos permitem entender o porquê do baixo nível de identificação do político, na esfera micro, com a política pública (valores e diretrizes) reivindicada como legítimo pela política macro priista. Em alguns estados o nível de identificação foi praticamente nulo, uma vez que se 
recusaram a entrar na descentralização. O governador de Michoacán, por exemplo, Cuauhtémoc Cárdenas (1980-1986), “um nacionalista revolucionário, se negou a entrar na descentralização naqueles termos” (López-Arellano, entrevista 2003).

Há que se assinalar, no entanto, que os avanços na descentralização se mostraram diferenciados nos 14 estados em que foram criadas as SESAs. Cada estado adotou a descentralização de acordo com o jogo político local. Entretanto, apenas dois casos merecem lugar de destaque: Morelos e Tabasco. Como ressalta o então Assessor da Secretaria de Morelos, “O caso de Morelos é bem singular. Tínhamos um governante populista, pertencente ao grupo dos velhos priistas, e era médico” (Molina, entrevista 2003).

O Dr. Lauro Ortega foi um dos colaboradores de Lazaro Cárdenas anos atrás. Em seu governo cresceram os recursos para saúde em Morelos. "Foi criada a $1^{0}$ Secretaria de Saúde e Seguridade Social no estado. Morelos não tinha hospital para população aberta, apenas um hospital IMSS-COPLAMAR, com 60 camas (com a descentralização este hospital vai para a SES). Lauro Ortega criou 05 hospitais. Também tínhamos projetos locais, quando o estado investia com recursos próprios. Acredito que a questão da saúde era uma forma de legitimação do governo de Lauro Ortega. Houve um efeito de mudança na saúde de Morelos, com o aumento do numero de trabalhadores, crescimento da infraestrutura e da cobertura da atenção. Em Morelos o governo decretou serviços gratuitos para o nível de atenção básica. Foi o único estado em que isto ocorreu” (Molina, entrevista 2003). Neste caso, o avanço da descentralização foi norteado por relações patrimonialistas próprias da política mexicana (Zabludovsky Kuper) (Arellano Gault). Os novos hospitais cidade, por exemplo, eram administrados pela mulher do governador (Molina, entrevista 2003).

O estado de Tabasco também compreendeu uma exceção. Em Tabasco 60\% dos recursos gastos em saúde eram do próprio estado. Trata-se de um estado petroleiro, e no âmbito da saúde tem uma escola de salubridade muito importante. É o estado que tem o maior índice de pós-graduados na área de saúde pública. Além disso, os governadores apoiaram a Secretaria de Saúde. Tabasco é um exemplo no país. Foi o primeiro estado que avançou com a descentralização a nível municipal. Criaram jurisdições sanitárias com 11 municípios (Molina, 2003) (Nigenda, 2001 e 2003). 
Apesar das exceções, a verdade é que a descentralização da saúde compreendia risco político e econômico em vários estados e, por tanto, não era reconhecida como legítima pelos principais atores políticos das esferas estaduais. Como ressalta Soberón, sabíamos que não seria fácil, por isto procuramos integrar os palitos fáceis (...) como num jogo de varetas, é preciso agarrar os fáceis primeiro” (Soberón-Acevedo, entrevista,2003).

Além dos motivos já citados, de oposição do IMSS e da falta de interesse dos governadores, a crise econômica também foi decisiva para interromper os acordos com apenas 14 estados, por causa da grande participação do governo federal no gasto com saúde. Ao empreender uma política de transferências de funções de atenção a saúde, sem que se verificasse mudança na estrutura fiscal, o limite final do esforço de descentralização foi dado pela própria política econômica. Esta procurou privilegiar medidas que objetivavam seguir o patamar do ajustamento fiscal acordado com o $\mathrm{FMI}^{82}$. Os efeitos da necessidade de financiamento do setor público podem ser vistos no gasto com saúde. A variação do gasto anual com saúde, que havia sido -0,6\% em 1982, chegou a -21,1\% em 1983 e -4,2\% em 1984, com pequeno aumento em 1985 e 1986 (2,8\% e 2,9\%), voltando a ser negativo (-7,7\%) em 1987 (Lustig). Neste contexto de contenção de gasto federal, Soberón recebeu do próprio Presidente a incumbência de descentralizar apenas mais três estados em 1986 e dois em 1987. É evidente que o intuito da descentralização, desde seu princípio, também era transferir o ônus do gasto público com saúde para os estados. Entretanto, paradoxalmente, no curto prazo este esforço só poderia ser impulsionado com a participação ainda massiva do orçamento federal. Os limites da descentralização foram acentuadamente maiores que as possibilidades de realização do público legalizado e reivindicado como legitimo na esfera política macro priista.

\subsection{Identificação social nula}

No que se refere à participação da comunidade, os documentos oficiais relatam que foram formados mais de 11.000 comunidades de atenção à saúde, bem como foram promovidas atividades para cerca de 100.000 voluntários na promoção da saúde em todo o país. Contudo, tal participação seguiu um padrão autoritário, de cunho patrimonialista. Observe que a LGS apresentava a participação apenas como o direito de recorrer à justiça em virtude do mau atendimento de saúde ou como direito de de participar como voluntário no processo de

\footnotetext{
${ }^{82}$ Veja Lustig e Branco na bibliografia.
} 
reforma. No México não existiam conselhos participativos que pudessem influenciar o processo decisório, ou monitorar a implementação.

Se entendermos que a participação implica no desenvolvimento de um processo decisório mais plural e de monitoramento da implementação, o nível de participação e de envolvimento da comunidade no período foi praticamente nulo no México. A decisão continuava se dando a partir da própria esfera política micro, enquanto a implementação ocorria sem monitoramento e prestação de contas junto a segmentos públicos. Os grupos de saúde, quando formados nos estados, como no caso de Tlaxcala, eram compostos por voluntários e se apresentavam como grupo de apoio à mulher (Rangel Paredez, entrevisto 2003). Há que se investigar, no entanto, se este tipo de relacionamento com a comunidade continua ou não a apresentar um caráter autoritário, por poder ter como objetivo antes conquistar o apoio político de parcela da população, do que possibilitar a inserção de novas idéias e a consolidação de posições de pressão sobre o processo decisório e de implementação.

Há que se assinalar ainda que, como tradicionalmente ocorre a cada sexênio, verificouse um decréscimo no ritmo de implementação dos programas do governo a partir do quarto ano do sexênio, uma vez que as ações do poder Executivo começavam a se voltar para a sucessão presidencial. Se não fosse pela crise fiscal e pelo ônus de gasto adicional com os danos do terremoto (1985), e pela proximidade do término do sexênio, possivelmente o governo federal teria estendido a descentralização para os demais estados. Como resultado, o conflito político instaurado entre os principais atores do sistema na decisão e implementação do novo domínio público reivindicado para o setor, evidenciou a predominância dos obstáculos à descentralização no nível micro. O baixo nível de identificação dos atores da esfera política micro estadual, de um lado, associado à importância atribuída pela política macro à crise econômica, de outro, revelaram os limites para a construção da legitimidade do novo domínio público-estatal na saúde.

\subsection{Interrompendo a construção de domínio público não reconhecido}

O esforço de legitimação da descentralização foi abortado em 1987 e com 14 estados apenas. Com a interrupção do processo antes mesmo do término do governo, a identificação deslocou-se do nível baixo1 para o nível nulo, visto que o processo de construção da descentralização foi encerrado. Tratou-se de um processo com alto índice de rejeição na esfera 
política micro, desde o princípio, caracterizado por uma construção parcial e por um nível extremamente baixo de identificação. Nestes 14 estados, a descentralização traduziu-se mais numa desconcentração operativa, com quase nenhuma autonomia política por parte dos estados, e com um acentuado grau de dependência dos recursos federais para a realização dos serviços.

A atenção médica pública limitou-se ainda sobretudo ao nível secundário da atenção, de alto custo, típico das práticas IMSSianas. Dados os obstáculos administrativos, de pessoal e à limitação financeira, estudos demonstram que a desconcentração acarretou o incremento da desigualdade de acesso aos serviços de saúde no país (López-Arellano \& Blanco-Gil, 1993). Ademais, com a transferência dos programas de controle de enfermidades para os estados, a desconcentração também produziu um desmantelamento temporal desses programas. “A regressão sanitária deste período pode ser exemplificada com o incremento na incidência da malária, dengue, tuberculose, com a epidemia de sarampo; assim como o incremento da mortalidade por desnutrição em pré-escolares e com o aprofundamento das diferenças de saúde entre os grupos e regiões (López-Arellano \& Blanco-Gil, 1993 e 2001). Ademais, os serviços de IMSS-COPLAMAR, transferidos para os 14 estados, sofreram um processo de desmantelamento, dado o menor percentual de recursos administrados pela SSA, bem como ao boicote realizado pelo pessoal do IMSS. De acordo com relatório elaborado pelo setor de pesquisa do próprio IMSS, a produtividade dos serviços mostrou-se bem maior nos estados não descentralizados, em que IMSS-COPLAMAR continuou sob o comando do IMSS. A exceção se deu no estado de Tabasco (Cuevas, 2003).

\section{Sucessão presidencial em tempo de crise}

Durante todo o governo de De la Madrid a inflação manteve-se em patamares elevados, voltando a ter três dígitos em 87 e 88. O PIB, por sua vez, apresentou variação negativa desde o primeiro trimestre de 1986 (INEGI, 2003). A dívida interna era de 19\% em relação ao PIB. Sendo que "a metade ${ }^{83}$ do orçamento era direcionada exclusivamente para o pagamento dos juros da dívida interna pública. Era uma situação insustentável” (Salinas, p.403). Como estratégia política para a sucessão presidencial, o governo lançou um novo pacote de políticas econômicas em 1987, após o lançamento da candidatura de Carlos Salinas para Presidente.

\footnotetext{
${ }^{83}$ Em 1988 o montante pago apenas com juros correspondia a 44,4\% de todo gasto público federal
} 
Tratou-se do Pacto Nacional de Solidariedade (Secretaria de Salud, 1990). Este compreendeu em rearticulação do Estado com o setor privado, dado o comprometimento do governo em aprofundar o processo de privatizações, utilizando estes recursos para pagar a dívida pública. Até março de 1988, este programa, apesar de não ter acabado com os três dígitos de inflação, produziu uma leve queda da inflação mês a mês e uma variação positiva no PIB. Esta variação chegou a 2,6\% no primeiro semestre de 1988. Estes resultados foram comemorados pela elite governamental e também foram suficientes para a conformação de um amplo pacto sobre a administração da economia. O Pacto Nacional de Solidariedade converteu-se em Pacto de Estabilidade e Crescimento Econômico (PECE) ${ }^{84}$. Como ressalta Salinas, "O Pacto demonstrava eficácia e conseguiu que os aumentos de preços fossem menores mês a mês. A inflação não terminou, mas contemos sua corrida acelerada. As pessoas não perdoaram o deterioramento do seu nível de vida, mas apreciaram o esforço governamental” (Salinas, p.948).

A classe trabalhista, bem como a classe média em geral e as classes menos favorecidas já haviam revelado seu descontentamento com o governo ao longo do sexênio, por meio, por exemplo, das “passeatas cívicas” - lideradas pela FDN (Frente Democrática Popular) - e das constantes ameaças de greves pelos sindicatos. Nos momentos de pressão popular, o governo decretou aumentos salariais de emergência. Estes aumentos, no entanto, se mantiveram a baixo da inflação (Lustig). Nas eleições estatais e municipais de (de 82, 85 e 86), a nova direita (PAN) e, sobretudo, a esquerda (FDN) também havia demonstrado o seu poder de mobilização política. Ademais, apesar das pesquisas nacionais apontarem para a vitória do PRI, as pesquisas do DF revelavam um virtual empate entre os candidatos do PRI e da FDN: Cuauhtémoc Cárdenas ${ }^{85}$. Outra "surpresa referia-se ao fato da coalizão dos partidos de Cárdenas superarem o PAN” (Salinas, p.949) nas pesquisas.

\footnotetext{
${ }^{84}$ Veja o relato de Brachet-Marquez (2001) e principalmente de Rousseau (2001) sobre como, na véspera das eleições presidenciais, o PSE possibilitou a conformação de uma ampla aliança da elite governamental com o setor privado, que passou a ter maior participação na política econômica.

${ }^{85}$ Ao deixar a governo de Michoacán em 1986, Cuauhtémoc Cárdenas encabeçou primeiramente uma corrente democrática dentro do PRI, e posteriormente como movimento independente. Foi o candidato a Presidência e coordenador nacional da FDN, formada pelos seguintes partidos de esquerda: Partido Autêntico da Revolução Mexicana (PARM), Frente Cardenista de Reconstrução Nacional (PFCRN), Partido Popular Socialista (PPS) e o Partido México Socialista (PMS), alguns na ilegalidade antes da reforma de Portillo, outros criados a partir de então.
} 
Em 06 julho, no dia da eleição, não foi possível divulgar os resultados como previsto, “O Conselho Técnico de Vigilância de Registro Nacional de Eleitores nos informou que o computador calou, felizmente não se tratava do verbo cair, mas do verbo calar” (Salinas, p. 949). Em resposta, a oposição denunciou a “ilegalidade do processo eleitoral”. Apesar da contestação de Salinas (2000), no que diz respeito à possibilidade de fraude, há um consenso na literatura e no meio político e acadêmico mexicano de que a fraude foi o meio utilizado pelo partido de Estado a fim de garantir a sua perpetuação na Presidência da República. Os resultados oficiais foram divulgados em setembro, dando vitória para Salinas. Este com 50,74\% dos votos, Cárdenas com 31,06\% e Clouthier (PAN) com 16,81\%. 


\section{Capítulo 5 - Rompendo com a descentralização da política pública de saúde: a regionalização solidária e patrimonialista do governo de Carlos Salinas (1988 a 1994)}

“Não havia tempo a perder, em 2 de dezembro de 1988, no dia seguinte de minha posse, pus em marcha o Programa Nacional de Solidariedade. Foi minha primeira ação de governo. $O$ evento ocorreu no Palácio Nacional com a presença de colonos, camponeses e indígenas das

regiões mais pobres"

(Salinas de Gortari, p.546).

Salinas assumiu o poder em meio a uma tremenda crise política, em que os resultados da eleição estavam sendo amplamente questionados na política e na mídia. $O$ descontentamento de camadas da sociedade civil com o governo priista havia sido uma das marcas da campanha presidencial. A instabilidade política evidenciada na virada do sexênio relacionava-se ao fato da política de reestruturação econômica ter ocasionado uma redistribuição concentrada e diferenciada da renda produzida no país.

Os custos sociais da política de ajustamento estrutural caíram principalmente sobre as classes mais pobres e média urbana. Foram estas camadas da população, sobretudo nos centros mais desenvolvidos, que deram seu voto a Cárdenas. No decorrer do sexênio anterior o poder aquisitivo do salário mínimo sofreu uma perda de 52\%, ainda não registrada no país até então. O desemprego atingia sete milhões de pessoas, correspondente a $20 \%$ da população economicamente ativa. O gasto público com bem-estar, que correspondia 17,2\% do orçamento em 1981, representava apenas 9,2\% do orçamento em 1987. A camada social beneficiada nesta primeira fase da transição do modelo econômico havia sido sobretudo a classe exportadora.

A instabilidade política traduzida nas contestações sociais lideradas pela coalizão de esquerda e revelada nas urnas dos centros urbanos mais desenvolvidos, adicionadas à possível fraude eleitoral comandada pelo partido do Executivo, produziu uma fragmentação na já precária coesão da ampla aliança política estatal, em especial no que se refere ao setor trabalhista, tradicionalmente inserido no poder por meio das instituições de cunho corporativo. Novamente a crise política traduzia-se em questionamento da legitimidade do partido de Estado. A sociedade havia sinalizado seu descontentamento com a política priista. Os empresários, por sua vez, haviam deixado seus interesses claros na campanha presidencial. 
De que forma a elite governamental tentará conciliar a necessidade de aprofundamento do modelo de liberalização econômica (atendendo aos interesses empresariais) com a adoção de políticas sociais que, ao atenderem às demandas da população em geral, garantiriam a sobrevivência do processo de dominação da nova facção priista no decorrer do sexênio?

\section{Decidindo por Solidariedad Social: ruptura e nova redefinição do público}

O time de Salinas optou por estratégias que lhes permitiriam sobreviver no processo. Estas estratégias, pensadas juntamente com os aliados diretos de Salinas - a geração de jovens da SPP -, “propunham remodelar as políticas e os mecanismos que asseguram o funcionamento interno do sistema e, de forma paralela, instalar uma nova geração no poder, ao mesmo tempo em que se garantisse a manutenção da estabilidade política e a volta do crescimento econômico” (Rousseau, p. 280). A proposta de política social seria uma das estratégias pilares do novo governo.

Mesmo com a oposição da nomenklatura (a velha facção priista), evidente desde a campanha eleitoral, o Programa Nacional de Solidariedade (PRONASOL) compreendeu o primeiro ato de governo do novo presidente. Tratava-se de uma das políticas centrais de Salinas na tentativa de reconstrução das bases de apoio político-sociais. As diretrizes gerais e a estrutura do projeto foram elaboradas mediante a conciliação de dois ideários distintos: o marco econômico neoliberal e o pensamento da esquerda mexicana.

A influência da economia neoclássica, derivada das pressões exercidas pelo empresariado aliado e pelas instituições monetárias internacionais, se encontrava presente no diagnóstico mais técnico da equipe de Salinas. Para os jovens economistas da SPP, o problema da pobreza ou extrema pobreza foi atribuído às políticas estatais equivocadas, implementadas por um modelo econômico voltado para dentro (substituição de importações). Para estes formuladores de políticas, foi a crescente intervenção governamental na área social que produziu déficits correntes nas contas públicas, fazendo com que o gasto com o bem-estar deixasse de ser eficaz para garantir as demandas sociais e assegurar a governabilidade (Barajas, 2002). Os novos economistas no poder usavam valores argumentos economicistas, fundamentados em valores utilitaristas deslocados da política e da sociedade, para entender o porquê do fracasso das políticas anteriores. O argumento economicista, hegemônico na política 
global e inserido na política do novo PRI, adquiriu um caráter politicamente determinante, configurando-se mais uma vez como fator decisivo nesta nova fase de redefinição do público.

Desta vez, no entanto, o diagnóstico da SPP não apontava para a continuidade da descentralização junto aos estados, mas para a necessidade de se subordinar a política de saúde, assim como as demais políticas sociais, a uma nova estratégia de política social: o PRONASOL. A subordinação das demais políticas públicas à econômica foi justificada mediante a criação de conceito ideológico de solidariedade social, o qual utilizava os ideais nacionalistas da Revolução Mexicana, de um lado, e os valores da economia neoclássica, de outro, para reivindicar ideologicamente o aprofundamento das reformas de mercado e, assim, justificar socialmente a adoção de novos programas sociais; que deveriam ter o caráter de solidariedade (O’Toole, 2003) (Barajas, 2002). O novo público reivindicado como legítimo baseou-se em programas de combate à pobreza, direcionados para regiões e comunidades de menor renda. A marca populista do público o diferenciaria dos programas solidários adotados nos períodos de Echeverría e Portillo (Capítulo 2).

Já a influência do discurso da esquerda mexicana residia no fato da população alvo de Solidariedade ser aquela que se encontrava marginalizada das instituições tradicionais: camponeses, comunidades rurais e indígenas. Ademais, Solidariedad incentiva a participação comunitária, a formação de comitês organizacionais, e não o corporativismo organizacional (Moguel) (Rodriguez) (Salinas de Gortari). De forma contraditória, mas politicamente significativa, PRONASOL conciliava os valores universais de mercado do neoliberalismo com os valores nacionalistas oriundos da esquerda radical mexicana.

Observe que, de um lado, a decisão pela não descentralização do público, na saúde, mostrou-se claramente contrária à recomendação neoliberal em voga. No entanto, tal fato não implicou em rompimento com a política global. A criação do PRONASOL demonstrava a intenção de México em aprofundar suas políticas sociais e de saúde segundo as recomendações globais das reformas de segunda geração de combate à pobreza. Tal intento explicitou-se no chamado "primeiro acordo de atenção básica de saúde”, firmado com o Banco Mundial. No entanto, o caminho da implementação de PRONASOL foi definitivamente mexicano (Ward, 1993), sem que houvesse nenhum tipo de controle/ monitoramento ou transparência, como veremos. 


\subsection{Solidariedad Social: a valorização do populismo e do patrimonialismo na política}

Há que se destacar ainda que PRONASOL foi apresentado como o projeto do próprio Presidente Carlos Salinas, e não como um projeto do PRI. A ênfase sobretudo inicial dada ao personalismo do Executivo visava conter as forças contrárias ao governo. Durante os primeiros anos o programa foi administrado por meio do exacerbamento da regras informais de cunho patrimonialista típicas da cultura política mexicana (Zabludovsky Kuper) (Arellano Gault). O novo público reivindicado pela política macro era administrado diretamente pelo gabinete presidencial. "De modo descentralizado - e muito arbitrário - Salinas pôde passar por cima dos governadores estatais e dos prefeitos, designando fundos a grupos locais e outras organizações” (Rodriguez, p.163). Sobretudo até meados deste período, solidariedad produziu um incremento no nível de identificação e aceitação na sub-esfera da política micro e na sociedade. A nova política pública era apresentado como "um novo padrão de relacionamento Estado-sociedade” (Salinas de Gortari) (Warman).

Os projetos locais de Solidariedade, ao serem produzidos com a participação comunitária, deram popularidade ao governo de Salinas, como conexão direta entre o governo e o povo. Como resultado destes primeiros anos, os líderes populares que apoiavam Cárdenas no novo Partido da Revolução Democrática (PRD) ${ }^{86}$, ao serem beneficiados pelo PRONASOL, deixaram de contestar o governo (Brachet-Marquez).

A partir de 25 de maio de 1992, Solidariedade passou a ser administrado pela nova Secretaria de Desenvolvimento Social (SEDESOL), que incorporou parte do grupo saído da $\mathrm{SPP}^{87}$. Praticamente toda a chefia da SEDESOL provinha da esquerda, além de serem próximos a Luis Donaldo Colosio: o secretário. As funções da SEDESOL foram desenvolvidas sobretudo por meio das delegações estaduais, cujos delegados se converteram em atores principais e por meio de quem eram articulados os programas federais, estatais e municipais. A nova burocracia antipobreza serviria simultaneamente para diminuir a dependência de Salinas

\footnotetext{
${ }^{86}$ Com a promulgação de novas leis eleitorais, Salinas havia conseguido impedir a formação de coalizões partidárias, como nas eleições de 1988. Estas leis, de um lado, ocasionaram a dissolução da FDN, como pretendia Salinas. De outro, levaram Cárdenas a criar o Partido da Revolução Democrática (PRD).

${ }^{87}$ A SEDESOL incorporou grande parte do time de confiança de Salinas, vindo da SPP. Esta foi dissolvida por decreto no início de 1992. A equipe da SPP se dispersou em três secretarias: Fazenda, Educação e Desenvolvimento Social (SEDESOL). O Comando da Educação ficou com Zedillo, e o da SEDESOL com Colosio.
} 
da hierarquia partidária priista original e para construir apoios pessoais em comunidades de menor renda (Kauffman \& Trejo, p.723).

Os efeitos perversos desta participação social populista e desta política patrimonialista viriam à tona até o final do período, como veremos a diante, revelando as intenções e comprometimentos da política macro. Isto é: A fim de desenvolver a economia de mercado no país, aprofundando a liberalização da economia ${ }^{88}$ e, assim, atender diretamente os interesses articulados na esfera de poder macro, a elite política salinista reivindicou a partir do próprio poder de matriz-cêntrica, sem que houvesse a interferência direta de pressões contrahegemônicas ou da velha guarda priista, a legitimidade de “solidariedade social”. Em tempo de crise de legitimidade e de permanência da matriz-cêntrica de poder, Salinas rompeu não apenas com a política pública de saúde anterior, mas com a própria velha guarda do Partido de Estado.

\subsection{Rompendo com a estratégia de descentralização: reivindicando uma nova legitimidade do público}

Embora a descentralização da política pública de saúde continuasse no discurso político, sendo apresentada como objetivo-alvo do setor (Poder Ejecutivo Federal, PNS, 1990), verificou-se de fato uma estagnação do processo de transferência da responsabilidade de serviços para os estados. O domínio público parcialmente descentralizado e abortado no período anterior, não foi mais reivindicado como legítimo pela política macro. O novo público foi inicialmente tratado como responsabilidade pessoal de Salinas e, em seguida, tal responsabilidade foi dividida com o novo Ministério criado: a Secretaria de Desenvolvimento Social: SEDESOL.

A ruptura com a estratégia de descentralização se deu não apenas "porque os estados continuaram mostrando-se intranqüilos para assumirem uma responsabilidade sem terem a segurança de que também seriam transferidos os recursos adequados” (Rodriguez, p. 163), mas, sobretudo, porque a descentralização da saúde passou a ser vista como uma estratégia de risco político, visto os efeitos epidemiológicos perversos ocasionados pela política, a necessidade de constante negociação com os governadores priista (da facção tradicional), e os

\footnotetext{
${ }^{88}$ Várias empresas públicas foram privatizadas no período, algumas empresas foram compradas por amigos ou atores próximos a Salinas, os novos milionários do país. A liberalização da economia, de forma política perversa, e similar ao caso argentino, ocorreu sem que houve mudanças nas estruturas políticas. Veja texto de Judith A Teichman, na bibliografia.
} 
conflitos com o IMSS no sexênio anterior. Ademais, as reivindicações de movimentos sociais da esquerda haviam crescido no final do período de De la Madrid. O salinismo ${ }^{89}$ objetivava estabelecer alianças com setores políticos até então excluídos da política priista tradicional. A regionalização de PRONASOL, e não a descentralização da saúde junto aos estados, seria a estratégia privilegiada para a realização de tal intento.

\section{Implementando uma regionalização político-patrimonialista}

\subsection{Evitando conflitos, mantendo a dualidade na assistência solidária do público}

Com a construção política de Solidariedad e, em seguida, com a criação da SEDESOL, o governo manteve centralizada a arrecadação tributária e o comando político das diretrizes gerais de várias políticas sociais e de saúde. Além disso, ainda conseguiu aporte do Banco Mundial para financiar parte de seu programa. Os programas de saúde incluídos sob a marca de Solidariedade $^{90}$ foram: 1) infra-estrutura de serviços de saúde, 2) IMSS-Solidariedade, 3) Hospital Digno e 4) Enfermeiras em Solidariedade.

Para a viabilização dos programas de saúde de Solidariedade, o antigo IMSSCOPLAMAR, rebatizado de IMSS-Solidariedade e devolvido ao IMSS, foi a instituição de saúde privilegiada para tal tarefa. Tal escolha baseava-se tanto em motivos operacionais, quanto políticos. Do ponto de vista operacional, IMSS-Solidariedade possibilitaria uma expansão mais rápida dos serviços de saúde, em virtude de sua infra-estrutura regional, bem como do fato de já conter sua própria estrutura administrativa e orçamento. Do ponto de vista político, se tornaria possível proporcionar serviços de saúde sem nenhuma interferência dos governos estatais e municipais. A ausência de conflitos entre SEDESOL e IMSS pode ser explicada pelo fato de IMSS-Solidariedade ter retornado para o comando do IMSS. Apesar de sua autonomia, pode-se dizer que IMSS-Solidariedade manteve-se sob a influência da Presidência e da SEDESOL, uma vez que a diretoria do IMSS $^{91}$, assim como de outras

\footnotetext{
${ }^{89}$ De acordo com alguns analistas, o intuito de Salinas era criar seu próprio partido, dissociando-se do PRI. Daí a origem da palavra "salinismo".

${ }^{90}$ Os programas sociais que levavam a marca Solidariedade eram divididos em áreas: 1) Solidariedade para o Bem-estar social, 2) Solidariedade para Produção, 3) Solidariedade para o Desenvolvimento Regional e 4) Programas de desenvolvimento regional. O sub programa Solidariedade em saúde encontrava-se na área de Solidariedade para o Bem-estar social

${ }^{91}$ Genaro Borrego assumiu a direção do IMSS. Já havia trabalhado no IMSS como chefe do Departamento de Desenvolvimento de 1973 a 1976.
} 
instituições tradicionais, que se encontravam sob a direção de um homem de confiança do presidente. As contestações sindicais, por sua vez, haviam sido minadas, dadas as mudanças feitas por Salinas na cúpula destas instituições.

No que se refere à Secretaria de Saúde, esta se encontrava sob a direção de Dr. Jesús Kumate, médico infectologista e subsecretário de Soberón ${ }^{92}$ no sexênio passado. Embora a SSA tivesse seu próprio Plano de Saúde, bem como sua própria parcela no orçamento federal, independente do orçamento de PRONASOL, a forma como esta instituição de fato empregou seus recursos foi orientada pelas diretrizes de PRONASOL. Como ressalta Leal, “a política de saúde do salinismo, com Dr. Kumate no comando, estava acorrentada. Seu compromisso político era com Solidariedade e só com Solidariedade, especialmente quando se tratava de uma área social estratégica. Ir além de Solidariedade significaria na criação de novas moedas de Solidariedade” (Leal, 2002, p.94). De forma que a implementação do novo público solidário na saúde, na esfera política micro, iria ser pautada por relações patrimonialistas, favorecendo a distribuição de recursos entre a clientela política salinista ${ }^{93}$.

Dentre os programas implementados pela SSA destacaram-se as campanhas nacionais de vacinação, e o Programa de Apoio aos Serviços de Saúde para População Aberta (PASSPA). As campanhas de vacinação cresceram em todos os estados do país, e para todos os produtos biológicos, após a criação do Conselho Nacional de Vacinação (CONAVA) em 1991. Este utilizava a infraestrutura do subsistema para população aberta em suas campanhas permanentes e periódicas. Já o PASSPA foi implementado nos estados privilegiados por

\footnotetext{
92 Soberón não foi mantido na SSA, possivelmente porque seu nome articulava-se diretamente com a fracassada política de descentralização iniciada por de La Madrid, e também apoiada pelo próprio Salinas, um dos economistas da SPP. No entanto, Soberón e seu grupo assumiram a direção do Instituto Nacional de Saúde Pública (INSP), que teve uma nova sede em Cuernavaca. Houve uma mudança radical no INSP, de ordem curricular e administrativa. O INSP passou a incorporar disciplinas quantitativas e da área de economia da saúde. Realizou convênios com a Escola de Higiene e Medicina Tropical de Londres, e com a Escola de saúde Pública de Harvard. Trata-se de centros promotores da economia de saúde no mundo. Como fruto deste processo, o INSP tornou-se conhecido como um dos principais centros de economia da saúde na América Latina. Com a reforma no INSP, os velhos sanitaristas foram mais uma vez marginalizados do poder. Além da mudança no INSP, Soberón aprofundou sua articulação com o setor médico privado e com a indústria de saúde, fundando, com o patrocínio destes setores, um think-tank voltado para a análise e formulação de políticas de saúde: a Fundação Mexicana para a Saúde (FUNSALUD). Tal processo é analisado por Abrantes e Almeida, veja texto na bibliografia. A volta do grupo de Soberón ocorrerá de forma indireta com Zedillo e, de forma mais explícita, com Fox.

93 Os recursos empregados nos estados não eram mais transferidos pela SPP/Ministério da Fazenda, mas pela SEDESOL. Salinas também entregava o dinheiro para a saúde em discursos políticos realizados nas localidades (Eibenchutz).
} 
PRONASOL. Um estudo de avaliação deste programa (Gómez-Dantes et al., 1999) ${ }^{94}$, para os estados de Chiapas, Hidalgo, Oaxaca e Guerrero, aponta que o programa aumentou a cobertura dos serviços de saúde, bem como contribuiu para melhorar os indicadores de saúde em geral. No entanto, esta mesma investigação não recomenda a adoção de novas iniciativas nos moldes do PASSPA. Essa avaliação negativa deve-se não apenas ao fato das ações de saúde terem tido um início tardio, visto que 55\% das obras só terminaram em 1994, mas sobretudo à ocorrência de múltiplos problemas de planejamento que existiram desde a elaboração do PASSPA, os quais impediram identificar de maneira precisa que parte dos avanços se deviam definitivamente ao programa. A pesquisa só recomenda a implementação de um programa nos mesmos moldes do PASSPA em casos de extrema urgência, desastre natural ou conflito bélico $^{95}$.

Ao promover uma desconcentração da política, PRONASOL produziu uma “descentralização genuína” (Rodriguez) no México, e mais especificamente, contribuiu para a regionalização da política num contexto de lenta transição de um regime de partido único (Kauffman \& Trejo). Neste contexto, em que a sociedade e a classe política, de esquerda ou centro-direita, contestavam o centralismo da política priista tradicional, a regionalização política mostrou-se como instrumento essencial para a obtenção de apoio ao governo em nível nacional. O processo de regionalização se deu sob o comando dos delegados dos Comitês Locais, designados pela equipe de Salinas. Esta regionalização centralizada pode ser caracterizada pela forma como ocorreu 1) o incremento da participação comunitária, 2) a alocação dos recursos para municípios e, por fim, 3) no modo como a estrutura de Solidariedade foi utilizada para fins eleitorais.

\subsection{Identificação social e participação limitada: ausência de controle e publicidade negativa}

O incremento da participação comunitária se deu por meio dos Comitês de Solidariedade e dos Conselhos Municipais de Solidariedade. Essa participação “operava de forma bastante simples: qualquer grupo organizado se aproximava do Pronasol e apresentava

\footnotetext{
${ }^{94}$ Os dados e relatórios utilizados nesta pesquisa já se encontravam nas mãos da diretoria do INSP desde o final do período de salinas, no entanto ainda não havia sido autorizado para pesquisa e publicação. Tal autorização só ocorreu após a derrota do PRI.

${ }^{95}$ Veja também pesquisa coordenada por Mario Bronfman, na bibiliografia.
} 
um projeto para qualquer tipo de obra pública” (Rodriguez, p. 166). No entanto, a intenção de promover de fato a participação da comunidade não se verificou no decorrer do processo. A participação comunitária mostrava-se limitada pelo poder dos delegados dos Comitês Locais, que selecionavam os programas e decidiam sobre sua implementação.

Como resultado, a comunidade local não tinha voz na elaboração dos projetos, nem se envolvia no decorrer da implementação. Prevalecia uma articulação autoritária, de cunho populista, entre a política e a sociedade. O nível de identificação social com o domínio público populista, apesar de se posicionar no nível Baixo2 no início do período, apresentou uma mudança no decorrer de sua execução; indo do nível Baixo2 para o Baixo1 ou mesmo Nulo, em alguns estados. O posicionamento do nível de identificação ainda em intervalos do nível Baixo (entre 1 e 2), bem como seu decréscimo abrupto, aqui estimado, deveu-se ao fato da política ter sido estendida apenas à clientela articulada com o poder. Tal participação limitada, como revelou a publicidade negativa de PRONASOL no final do período, não se traduziu na representação dos interesses e necessidades do público em geral, como ter acesso com qualidade ao serviço de saúde. Esta percepção negativa em relação à política pública se mostrará evidente em Chiapas, um dos estados estratégicos na implementação de Solidariedad Social. Os efeitos perversos dos programas adotados, como o PASSPA, mostraram-se como um dos fatores determinantes da Revolução originada no estado no final do período de Salinas, como veremos.

\subsection{Identificação política: personalismo e corrupção}

Solidariedade também apresentou uma regionalização política perversa dos recursos e de tomada de decisões, ao designar fundos federais diretamente aos comitês de projetos e a seus conselhos municipais, em vez de canalizá-los para os governos estaduais e municipais. Os recursos federais para os Comitês Locais, por exemplo, eram canalizados por meio de dois fundos: O Fundo de Recursos para Infraestrutura (FAIS) e o Fundo de Recursos para o Fortalecimento dos Municípios e Distrito Federal (FAFM). De acordo com documentos oficiais, estes recursos foram administrados pela SEDESOL e distribuídos aos Comitês de acordo com uma fórmula baseada em critérios de indicadores de pobreza por estados e municípios. A maioria das transferências do FAIS e FAFM foram destinados para Chiapas, Oaxaca, Veracruz, Guerrero e Puebla. Eram os Comitês que concentravam os recursos e a 
função de distribuição de responsabilidade de execução entre as autoridades estatais e municipais.

Com efeito, a administração destes recursos se deu sem a adoção de mecanismos de controle ou prestação de contas. Em “1993 (já) havia se formado cerca de 150 mil” Comitês, “que exerciam um poder discricionário sobre a alocação de recursos e execução dos programas” (Laurell, 1994, p.31). Como resultado, a implementação do público Solidariedad permitiu a externalização dos valores e práticas políticas latentes e reprimidas por anos de centralização pela política priista. Há que se destacar ainda o fato dos principais jornais e organizações do país terem denunciado “o uso de fundos eleitorais do PRONASOL, freqüentemente com a apresentação de provas incontestáveis” (Laurell, 1994, p.31).

Nesta terceira etapa da lenta transição de regime político - iniciada com Portillo -, não foi mais possível ao poder controlar a publicidade crítica aos programas do PRI no México. O baixo nível de identificação da esfera política micro com a macro deveu-se ao fato da elite local tradicional ter sigo marginalizada por Salinas, à forma como os Conselhos Locais procuraram implementar a política pública, bem como aos efeitos sociais perversos vindos à tona.

\section{O retorno aprofundado da crise sócio-política e a sucessão presidencial}

Apesar das críticas e escândalos de corrupção que surgiram, as relações políticas patrimonialistas do público Solidariedad produziram ganhos políticos para o PRI na sucessão presidencial de 1994. Esta sucessão foi a politicamente mais instável na História recente do México. Dentre os eventos que alimentaram a instabilidade política do último ano de Salinas, destacaram-se 1 ) as críticas ao PRONASOL ${ }^{96}$, com atenção para a situação de extrema pobreza em Chiapas; 2) a Rebelião de Chiapas iniciada em janeiro, 3) os assassinatos de lideranças do partido de março a dezembro, como o candidato à presidência - o ex-secretário da SEDESOL: Donaldo Colosio - e o secretário nacional do partido: Ruiz Massieu; 4) e as suspeitas de envolvimento de membros do PRI com o crime. Neste contexto de crise de legitimidade do

\footnotetext{
${ }^{96}$ PRONASOL foi considerado um fracasso como programa de extinção da pobreza. Veja os textos de Barajas, Soria, Laurell e Brachet-Marquez, na bibliografia. Também foi um programa marcado pela constante corrupção e desvio de verbas.
} 
PRI, a economia foi mantida estável à custa da captação do capital de risco internacional ${ }^{97}$. E mesmo em meio à crise política, o PRI obteve ampla vitória nas eleições presidenciais ${ }^{98}$. A vitória de Zedillo - o candidato indicado pelo partido após o assassinato de Colosio - foi garantida pela sustentação política adquirida pelo governo com o público Solidariedad, de um lado, e com as políticas de privatização e estabilização da economia, por outro.

O público solidário reivindicado por Salinas teve, por fim, sua legitimidade questionada ao final do período. A implementação de Solidariedad revelou que seu intuito principal era antes justificar política e socialmente o aprofundamento da reestruturação econômica, bem como tecer relações políticas com clientelas locais. Esta última intenção mostrou-se clara nos efeitos perversos de PRONASOL: fim político eleitoral, corrupção, desvio de verbas e não combate à pobreza. A intenção de reestruturação econômica, na área da saúde, mostra-se evidente com o fator dos setor privado de saúde - composto pelo setor de atenção médica e de seguros de saúde -, ter conseguido algo ainda inédito na História mexicana: o privado cresceu de forma extremada em relação ao público (Soria). O incentivo ao seguro médico, em crescimento deste 1987 (Laurell, 1995), deu-se com a instituição da redução no imposto de renda ${ }^{99}$.

\footnotetext{
${ }^{97}$ México havia ingressado ao NAFTA desde janeiro de 1994. Em meio às crises o Secretário da Fazenda emitia novos títulos de captação de curto prazo, comprados sobretudo por Estados Unidos e Canadá. Caso os compradores destes títulos não quisessem renová-los no futuro próximo, a economia mexicana teria que sofre r as conseqüências da saída de 30 mil milhões de dólares a partir de dezembro de 1994.

${ }^{98}$ O PRI obteve 48,69\% dos votos totais, o PAN 25,92\% (20,87\%) e o PRD 16,58\%. Em relação a 1988, o decréscimo no percentual de votos do PRI foi acompanhado pelo incremento dos votos do PAN e sobretudo da esquerda cardenista (agora no PRD).

${ }^{99}$ Sobre o crescimento do setor privado no México, veja texto de Tamez \& Eibenchutz, na bibliografia.
} 


\section{Capítulo 6 - Crise política, estabilização econômica e retomada da descentralização da política pública de saúde no governo de Zedillo (1994 a 2000)}

“Ao impulsionar o federalismo, a premissa fundamental da Reforma Política do Estado é consolidar a unidade nacional, assim como considerar a diversidade geográfica, etnográfica, social e cultural, isto é, propiciar o desenvolvimento integral da Nação, fundamentado em regiões prósperas e em estados e municípios fortes, em que se combate os contrastes a fim de termos um México mais democrático, equilibrado e justo”. (PNF, Programa para um Nuevo Federalismo, p.10)

Zedillo assumiu o governo em meio a uma crise política e partidária ímpar na História do PRI. Esta crise foi desencadeada por uma série de eventos que trouxeram à tona os efeitos político-sociais da estratégia política salinista, bem como revelaram as divisões existentes não apenas no âmbito da própria elite governamental - originária na SPP - como também dentro do PRI, entre neoliberais e nomenklatura ${ }^{100}$. Esses eventos tiveram início no final de 1993, exatamente quando o grupo da SPP parecia ter motivos de sobra para comemorar o êxito das políticas públicas adotadas. Do ponto de vista da economia, o sucesso da estabilização mostrava-se evidente na queda drástica da inflação e o da liberalização econômica na entrada em vigor do Nafta. No que se refere à reforma social, seu êxito político sustentava-se na ampla rede de apoio obtida com PRONASOL e na conseqüente nominação do candidato de Salinas à Presidência.

\section{Crise impar em tempo de neoconservadorismo: 0 peso político do determinismo econômico na nova redefinição do público}

Brachet-Marquez descreve bem o caráter singular desta crise.

"Poderíamos dizer que a convergência de acontecimentos que levaram (à crise) foi única, e por tanto, imprevisível: primeiro, a rebelião em Chiapas, seguida, depois, pelo assassinato de Colosio, o qual foi acompanhado da incompetência policial e judicial; em seguida a nomeação apressada de Zedillo (sem relação aparente com as necessidades do momento, as quais exigiam uma figura conhecida e reconhecida); e finalmente o impasse

\footnotetext{
${ }^{100}$ Estas divisões se davam em torno das mudanças nas políticas públicas, sobretudo a econômica e a social, e em torno da forma como Salinas estava conduzindo a sucessão presidencial. Veja trabalho de Rousseau.
} 
econômico cada vez mais perceptível, mas desatendido pelo governo a fim de melhorar sua imagem na batalha eleitoral de agosto. As eleições, apesar de terem sido ganhas pelo PRI, foram carregadas por tensões e incerteza. A este momento se sucedeu outro, igualmente carregado de emoções contraditórias, quando foi assassinado José Francisco Ruiz Massieu, então Secretário Geral do PRI, o que desatou uma campanha de acusações e contra acusações no seio da elite partidária, e levou à fracassada prisão de um 'suposto culpado', na pessoa do deputado Manuel Munõz Rocha, que culminou com a prisão de Raúl Salinas Gortari, irmão do presidente Salinas” (Brachet-Marquez, p.258-9).

A elite governamental que ascendia ao poder, apesar de fazer parte do grupo neoliberal priista da SPP, possuía algumas características distintas em relação aos dois últimos sexênios. Zedillo era um jovem tecnocrata com doutorado em economia em Yale. Não fazia parte nem da nomenklatura priista, nem do time que havia formado a facção neoliberal do PRI desde os anos 80. Era de fato uma figura nova tanto no PRI quanto na administração pública mexicana. Teve portanto que formar seu próprio time de governo com base em suas limitadas relações políticas (Rousseau). Na chefia da SPP, por exemplo, que voltaria a ter destaque no governo, colocou uma segunda geração de jovens economistas, na maioria recém doutores de Yale e sem prática na administração pública ${ }^{101}$. Para o Presidente e sua equipe de confiança a situação de crise vigente foi interpretada como desafios políticos que colocariam à prova sua capacidade de governo (Rousseau). Foi em respostas a estes desafios e mais especificamente, à forma como os desafios políticos internos foram conciliados às demandas externas que se deu a conformação da agenda do novo governo. Nesta agenda, Zedillo e sua equipe procuraram conciliar a questão da continuidade com a necessidade de se aprofundar mudanças nas políticas públicas e no regime político.

O caráter de continuidade da agenda mostrava-se presente na intenção de prosseguir como as políticas econômicas de cunho neoliberal. Já o caráter de mudança residia na revalorização do federalismo, sob a forma do Novo Federalismo. Tratava-se de um programa estratégico, relacionado ao Plano Nacional de Desenvolvimento, e a ser aplicado a várias reformas setoriais, no intuito de resgatar sobretudo a unidade nacional. Esta opção estratégica pelo federalismo advinha do esgotamento político da matriz cêntrica mexicana, o qual

\footnotetext{
${ }^{101}$ Veja o trabalho de Rousseau para mais detalhes sobre a composição do novo governo e mudanças nestes cargos ainda no primeiro ano, sobretudo as mudanças na área financeira e na própria chefia da Secretaria da Fazenda (SHCPP), ocasionadas pelo "erro de dezembro".
} 
mostrou-se mais diretamente evidente com a regionalização da política e com a revolta de Chiapas.

Esta revolta utilizou-se do artigo constitucional 39, de soberania popular, para declarar um basta à centralização política de 70 anos comandada pelo PRI. "Pero nosotros HOY DECIMOS ¡BASTA!, somos los herederos de los verdaderos forjadores de nuestra nacionalidad, los desposeídos somos millones y llamamos a todos nuestros hermanos a que se sumen a este llamado como el único camino para no morir de hambre ante la ambición insaciable de una dictadura de más de 70 años encabezada por una camarilla de traidores que representan a los grupos más conservadores y vendepatrias (EZLN, 1993). O movimento exigia ainda a renúncia do presidente Salinas e se utilizava da Convenção de Genebra para legitimar internacionalmente a rebelião contra o governo federal. Declarava Chiapas como território insurgente, por fim, em guerra contra o Exército do governo nacional. A rebelião teve prosseguimento nos anos de Zedillo e continuou a ter relevância política no cenário nacional e internacional. No que se refere ao renascimento do regionalismo político, este se dava "sob várias formas de política multipartidária, reações de políticos da velha guarda, e construção de uma nova rede de políticos na administração” (Kauffman \& Trejo, p.742). Como resultado, nos primeiros anos de Zedillo, “o controle dos estados e municípios eleitos tornou-se mais significante para os políticos do PRI e para os burocratas do governo” (Kauffman \& Trejo, p.743).

Além destes fatores políticos, o fator econômico também se converteria em elemento político determinante para a renovação do federalismo. Apenas vinte dias após a posse de Zedillo, a crise econômica de dezembro de 94 trouxe à tona o caráter vulnerável da liberalização mexicana e, assim, pôs em cheque a capacidade do Estado gerenciar sua economia. A fim de obter recursos para restaurar a confiança do país e a estabilidade política, a elite governamental firmou novos acordos com as agências econômicas internacionais, e passou a acatar de forma mais explícita as demandas dos Estados Unidos - apesar das críticas e descontentamentos surgidos no país -, no sentido de avançar com as reformas de políticas públicas (Morris \& Passe-Smith, 2001). Dentre as exigências internacionais encontravam-se as recomendações de descentralização das políticas públicas. De forma que apesar da descentralização de Zedillo também ter sido originada pelos desafios políticos internos, num 
momento posterior a motivação política interna e a pressão externa se retro-alimentaram e passaram a ser os motores das propostas de descentralização do período.

A ausência de participação política direta de atores contra-hegemônicos no processo decisório, o papel central retribuido à SPP/Ministério da Fazenda e a conseqüente predominância da política econômica na elaboração da reforma da saúde, explicam porque as recomendações internacionais, já largamente utilizadas pelo think-tank (FUNSALUD) que auxiliou na preparação da estratégia de descentralização, tiveram uma influência direta maior nesta fase da reforma do público na saúde.

As mudanças ocorridas nas políticas públicas, neste tempo de liberalização econômica e de etapa mais avançada da transição de regime político, resultaram da articulação entre os interesse político inseridos na esfera macro e os interesses da política global, dentro de um marco estrutural em que as pressões de baixo continuavam ou dependentes da política de matriz-cêntrica ou politicamente filtradas e negociadas no âmbito da própria política. Além de consolidar a almejada unidade nacional, as políticas de descentralização também pretendiam promover uma administração mais eficiente do domínio público (Cabrero \& Carrera, 2000) e a integração do sistema público dual de atenção à saúde, seguindo as recomendações de Segunda Geração do Banco Mundial (Quadro 6.1).

O Banco Mundial, com base na avaliação do Primeiro Projeto de Atenção Básica, passou a fazer algumas recomendações mais precisas para México, utilizando o país como exemplo da necessidade de se efetuar a descentralização, a fim de obter um maior controle e eficiência na alocação e gasto dos recursos no setor. De acordo com documento interno do próprio Banco, referindo-se à equipe que "elaborou” o Terceiro PAB, “o time do país incorporou as lições aprendidas durante o Primeiro Programa de Atenção Básica e desenhou um Projeto baseado em princípios técnicos e metodologias sólidas ${ }^{\mathbf{1 0 2}}$, bem como nos resultados da experiência de campo. O Governo reconheceu desde o início da preparação do Projeto que a descentralização dos serviços era crucial para atingir a população não servida e a incorporaram como o principal pilar do programa de reforma do setor saúde” (World Bank, 2002, p.20)

${ }^{102}$ Grifo meu 
Quadro 6.1. Políticas de Segunda Geração: combater a pobreza e criar regras institucionais para o crescimento do mercado.

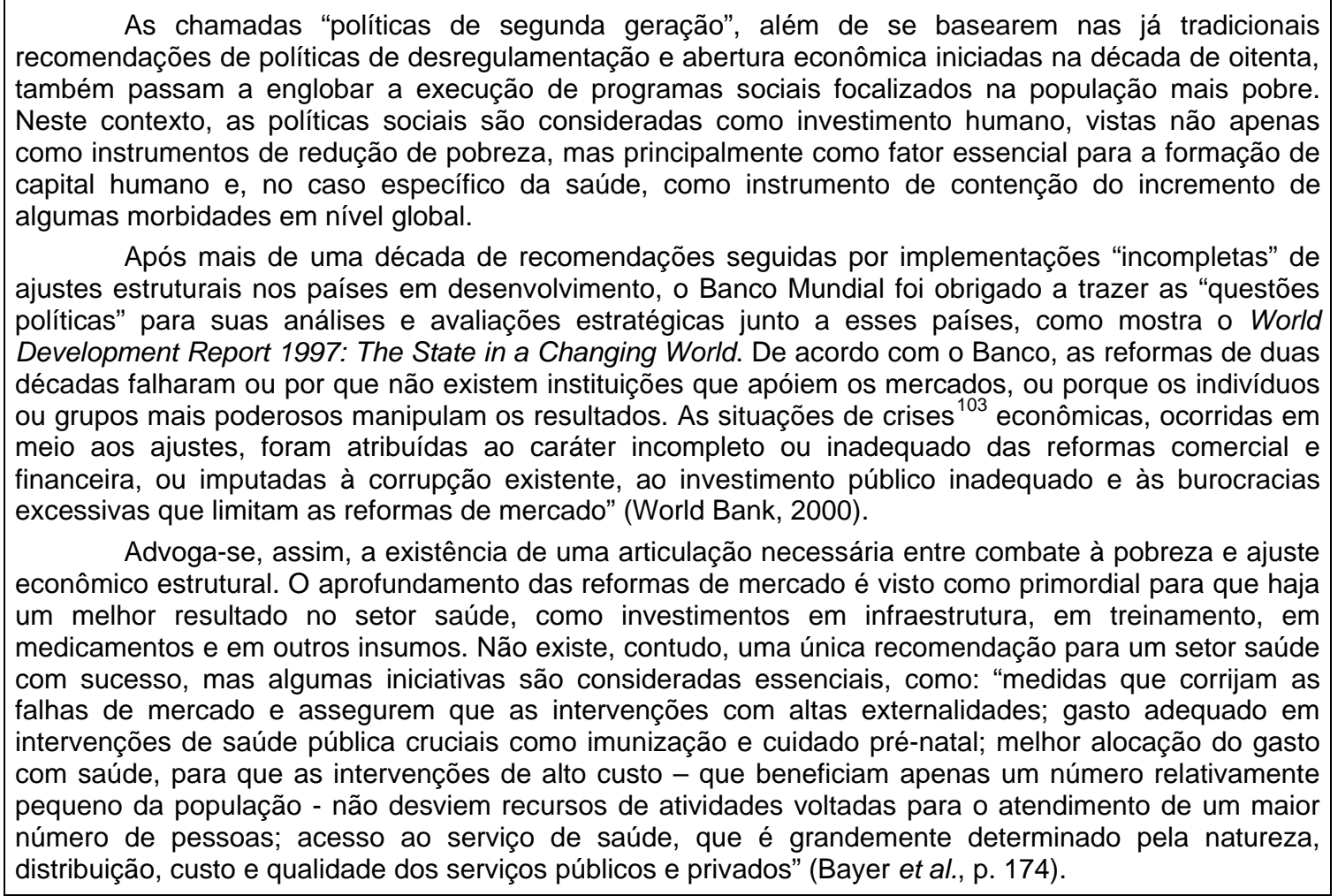

\subsection{Decidindo pela descentralização na saúde: autoritarismo priista e pressão global}

A elaboração da estratégia de descentralização da saúde, especificamente, esteve a cargo da própria assessoria do Presidente da República, e não se constituiu em tarefa delegada ao novo secretário de saúde. O Presidente e seu grupo, desde o conturbado período da sucessão presidencial, já haviam optado politicamente pela reversão do quadro centralizador das políticas públicas, e pretendiam estender essa estratégia à política de saúde pública, levando a descentralização para todos os estados. Quando esteve no comando da Secretaria de Educação Pública, Zedillo havia logrado implementar a descentralização da educação. Seu intuito era acompanhar de perto a elaboração da proposta da descentralização da atenção pública à saúde a fim de garantir que este processo fosse o menos conflituoso possível, e a se certificar de que as propostas da reforma estariam voltadas para a minimização dos obstáculos e dos embates entre os principais atores do subsistema de saúde. Daí o porque da elaboração deste projeto ter sido

${ }^{103}$ Como a crise do peso mexicano e a crise asiática de 1997 
editada por Luis Téllez, assessor do Presidente, com a consultoria do FUNSALUD, um thinktank fundado em 1985 pelo ex-secretário de saúde, Dr. Soberón, nos últimos anos do sexênio de De la Madrid (Leal, 2003) (Leal, 2000).

No posto de secretário de saúde Zedillo colocou um clínico renomado, de prestígio nacional e internacional. Dr. Ramón de la Fuente é membro honorário de várias sociedades nacionais e internacionais, ex-diretor na Faculdade de Medicina da UNAM (de 91 a 94) e atual reitor dessa mesma universidade. Como ressalta Leal, com a escolha de Ramón de la Fuente, Zedillo "silenciou todas as vozes inconformadas e pôde orientar de Los Pinos a reforma da saúde. Apoderou-se dela, por meio de seu coordenador e assessor Luis Téllez, que assistido por la Fundación Mexicana para la Salud (FUNSALUD) - dirigida por Guillermo Soberón, havia se convertido num furioso defensor do free market - desenhou toda a 'reforma'” (Leal, 2002, p.95).

É verdade que na nova proposta de descentralização do setor, Zedillo e Téllez de certa forma tentaram utilizar o aprendizado de Zedillo com a federalização da educação, mas há que se reconhecer que, sobretudo, conciliaram os marcos e aprendizados da anterior descentralização da saúde com as recomendações internacionais para o setor e, mais especificamente, com as "Notas de Estratégias” entregues pelo Banco Mundial ao governo federal $^{104}$. Estas notas reconhecem a dificuldade de implementação da descentralização no México; fato aliás constatado pelo Banco no decorrer das reformas de Primeira Geração ou Consenso de Washington no mundo. De forma semelhante a outros documentos do período, tais notas conciliam questões de eficiência econômica típicas do federalismo fiscal tradicional (nas Ciências Econômicas e utilizado no Consenso de Washington) com o argumento de redução da pobreza (Quadros 4.1 e 6.1).

Neste novo tempo de aprendizado da política global, a descentralização não apenas continua a ser considerada como estratégia essencial para as reformas, como também passou a ser vista como um dos principais desafios no processo de redefinição do público no mundo e,

\footnotetext{
${ }^{104}$ Estas notas foram entregues ao futuro Governo em 1994, e a pressão para a implementação das mesmas se deram de forma mais acirrada após a crise causada pela desvalorização do peso em dezembro. O atual Presidente Fox recebeu este mesmo tipo de recomendação, não mais em Notas, mas por meio da publicação México: Una agenda Integral para el Desarollo para la Nueva Era.
} 
em particular, nos países em desenvolvimento. Nestes países as vantagens ${ }^{105}$ da descentralização não puderam ser observadas em duas décadas de reformas. Dentre os desafios aprendidos encontrava-se o fato de poucos países terem longas experiências com descentralização no setor saúde, e do impacto ou implementação da ter sido pouco avaliado até então. Além disso, devido às várias problemáticas e aos diversos formatos dos serviços de saúde, bem como ao fato da descentralização do setor saúde ser geralmente direcionada pela política nacional/local, a descentralização da saúde é tida como a mais problemática em relação às demais políticas setoriais (World Bank, 1999).

A minha interpretação para o caso mexicano é que a nova elite política priista procurou uma saída para a crise de governabilidade atendendo antes às vozes das agências econômicas internacionais. Ao fazerem isto, tentava-se construir novas bases de legitimidade de fora para dentro, seguinte antes valores universais de mercado, já politicamente significativas na nova ordem mundial, do que os ideais da Revolução Mexicana. Nestes termos, não havia espaço para uma a conciliação com o velho PRI. Os valores e diretrizes de origem externa encontravam-se não apenas nas notas entregues pelo Banco Mundial, mas também nas análises de economia ${ }^{106}$ da saúde desenvolvidas pelo think-tank representante dos interesses privados de saúde e participante na redefinição do público. Nesta nova etapa de aprofundamento da influência da ortodoxia econômica sobre a agenda da saúde na esfera política macro, as recomendações já se pautavam num novo consenso político global, caracterizado como políticas de segunda geração (Quadro 6.1).

O Programa de reforma do Setor Saúde (1995-2000) apresentou duas estratégias distintas, direcionadas, de um lado, para a descentralização da saúde junto aos Estados e para o aumento da cobertura junto à população não assegurada, e, de outro, para a reforma da

\footnotetext{
${ }^{105}$ Onde funciona de forma efetiva, a descentralização contribui para: 1) aliviar o peso causado pelo planejamento do governo central e pelo controle de atividades econômicas e sociais; 2) simplificar os procedimentos burocráticos e pode incrementar a sensibilidade do servidor público em relação às necessidades locais; 3) ajudar os ministérios a alcançarem um maior numero de áreas locais com serviços; 4) aumentar a representatividade de vários grupos políticos, étnicos, religiosos e culturais no processo de decisão; 5) aliviar os gestores chaves dos Ministérios centrais das rotinas de tarefas, permitindo que eles se concentrem na política; 6) criar maior oportunidade de participação dos residentes locais no processo de decisão; 7) ocasionar programas responsivos mais criativos e inovadores; 8) aumentar a estabilidade política e unidade política, ao permitir que os cidadãos controlem programas públicos no nível local (Rondinnelli, 1999, p. 4 ).

${ }^{106}$ Uma das características da economia da saúde, como da própria economia, é a sua independência da política, fundamentada em princípios normativos deslocados da realidade social e limitados as clausuras e princípios derivados de método individualista que vigora na análise econômica.
} 
seguridade social no âmbito do IMSS. Na nossa interpretação, a apresentação desta dupla estratégia deveu-se não apenas à exigência do Banco Mundial no que se refere à reforma do sistema de pensões ${ }^{107}$. Correspondia também em estratégia do governo federal a fim de efetuar mudanças numa das instituições pilares do corporativismo mexicano.

No que se refere à descentralização junto aos estados, o novo programa apresentou semelhanças e novidades em relação à reforma dos anos 80. De forma semelhante ao período de Soberón, a descentralização constituiu-se numa das propostas centrais de reforma do subsetor de saúde para população não assegurada. O novo programa também assinalava as desvantagens geradas pelo centralismo, como falta de coordenação e duplicidade de gasto e funções. Determinava ainda que os serviços do atual IMSS-Solidariedade deveriam ser entregues aos governos estaduais, a fim de se formar os Sistemas Estaduais de Saúde (SESA). Como reconhece a literatura, o programa de Zedillo "reedita as considerações sobre a necessidade e vantagens de descentralizar e expressa objetivos semelhantes aos elaborados em 1984-88” (López-Arellano \& Blanco-Gil, 2001). O programa também retoma os valores e as diretrizes editados na Lei Geral de Saúde de 1984 (Quadro 4.1).

Já o caráter de novidade do novo programa deveu-se ao fato da proposta de descentralização ter como eixo central o Programa de Aumento da Cobertura (PAC) para a população não assegurada. Este incremento deveria ocorrer por meio da implementação do Pacote Básico de Serviços de Saúde (PBSS), que seria empregado inclusive com fundos do Banco Mundial ${ }^{108}$, mediante a assinatura do Segundo PAB (World Bank, 2003). A descentralização, além da promoção do acesso básico a serviços de saúde, e o apoio para a modernização da SSA no nível federal, eram considerados prioritários neste acordo de financiamento (World Bank, 2003, p.2).

\footnotetext{
${ }^{107}$ A reforma do IMSS não será analisada neste trabalho. Vale ressaltar, no entanto, que foi uma condição imposta pelo Banco Mundial a fim de conceder maiores empréstimos ao México (Laurell, 1998). Com a nova Ley do IMSS de 1995, a instituição passou por uma reforma profunda; teve seu quadro de chefias modificado e foram introduzidos mecanismos de mercado para alocarem seus recursos, por meio da ampliação da cobertura através de um pacote básico para assalariados não necessariamente inseridos no mercado formal de trabalho. Veja os trabalhos de González Rossetti \& Mogollon (Enhancing the political feasibility of health reform: the Mexican case. Harvard School of Public Health / Latin America and Caribbean Regional Health Sector Reform Initiative), e de Ramirez López (La seguridad social: reformas y retos. México, IIES-UAM, Miguel Ángel Porrúa, 1999).

${ }^{108}$ Estes programas básicos já vinham sendo amplamente recomendados nas publicações do FUNSALUD.
} 
As “ações essenciais irredutíveis de saúde” desta nova fase de descentralização junto aos estados deveriam privilegiar um conjunto limitado de 12 intervenções do pacote básico ${ }^{109}$ como definidos no Programa de Reforma do Setor Saúde (Poder Ejecutivo Federal, 1995). O PBSS também seria implementado em 380 municípios de alta marginalização, localizados em 11 estados $^{110}$. Nestas localidades, IMSS-Solidariedade, com suas unidades médicas e hospitais em zonas rurais marginalizadas, também seria utilizado para a descentralização do pacote básico. Comparado com a experiência brasileira, o PAC não é apenas o principal programa destinado a estender a cobertura de saúde para a população, como também revela o escopo estreito da reforma em termos do nível da atenção médica. Diferentemente do PSF, o PAC não tem fim alcançar a integralidade da atenção, funcionando como porta de entrada para os serviços mais complexos de atenção médica. O intuito é consolidar o PAC, ou programas similares, como a principal porta de acesso público na saúde.

\subsection{Evitando conflitos com os governadores e o IMSS: algum aprendizado}

Diferentemente dos períodos anteriores, o processo decisório da política zedillista também foi caracterizado pela negociação com os governadores. Zedillo reuniu todos os titulares das secretarias estaduais num único fórum político de negociação fechada, sob o comando do titular da SSA, em torno de questões chaves sobre a competência das entidades federativas e a implementação da descentralização junto aos estados. O Conselho Nacional de Saúde (CNS) foi criado em janeiro de 1995, como instância máxima permanente de coordenação entre as autoridades de saúde do governo federal e dos estaduais. O CNS era encarregado pelo planejamento, programação e avaliação dos serviços de saúde em todo o país. Este fórum era presidido pelo Secretário de Saúde, e integrado pelos titulares de saúde dos estados. Dentre os trabalhos desenvolvidos pelo CNS destacaram-se os diagnósticos sobre os serviços de saúde, os inventários dos bens das secretarias, as diretrizes para operação do PBSS e a definição da responsabilidade diretora e programática da SSA e de competência das

\footnotetext{
109 Estas ações se limitavam ao 1) saneamento básico familiar, 2) administração dos casos de diarréia, 3) tratamentos antiparasitários, 4) identificação de infecções respiratórias agudas; 5) prevenção e controle da tuberculose pulmonar, 6) prevenção e controle da hipertensão arterial e diabetes, 7) vacinação, 8) vigilância nutricional e crescimento da criança, 9) serviços de planejamento familiar, 10) atenção pré-natal, do parto e puerperio, 11) prevenção de acidentes e tratamento de lesões, 12) participação social.

${ }^{110}$ O programa inicial se destinava aos municípios localizados em 11 estados: Campeche, Chiapas, Guerreo, Hidalgo, Muchoacán, Oaxaca, San Luis Potosí, Yucatán, Veracruz y Zacatecas (Poder Ejecutivo Federal, PNS, 1995). No decorrer do processo, mais sete estados adotaram o PAC, compreendendo 18 estados no total.
} 
entidades federativas. Definiu-se ainda que a descentralização compreenderia duas linhas complementarias: a descentralização dos recursos operativos e a descentralização das atividades substantivas. Esta implicava a transferência dos serviços de saúde, de vigilância epidemiológica e regulação sanitária, enquanto aquela consistia na transferência dos recursos humanos, financeiros e materiais. Estas duas linhas de transferência deveriam ocorrer ao mesmo tempo.

Como bem ressaltou Ornelas, "As funções principais deste conselho (o CNS) são de caráter político; por meio da geração de consensos se tenta incrementar a legitimidade do regime na consulta e escuta das autoridades locais, sem perder o controle do processo no cumprimento das metas estabelecidas” (Ornelas, p.199-200). A reforma da saúde mexicana e, em particular a descentralização, não foi discutida com a sociedade, nem com facções da burocracia. A aprovação do projeto foi garantida pela predominância do PRI no congresso, neste início de sexênio. De modo que tanto a elaboração quanto a "negociação” da proposta se deram ainda num contexto de transição política centralizado pelo partido hegemônico.

\section{Implementando um novo domínio público sem participação social}

A dinâmica do processo político micro da descentralização, assim como as problemáticas reveladas no decorrer do processo foram marcadas pela forma como os atores chaves da esfera atuaram no decorrer da decisão e implementação, bem como pelo modo como o Executivo Federal procurou promover as relações federativas subjacentes ao setor de saúde. Vejamos primeiramente como se deu a relação entre três atores chaves do sub-sistema de saúde para a população aberta: SSA, secretarias estaduais, e IMSS-Solidariedade. Estas relações podem ser verificadas na forma como se deu 1) o processo de transferência da responsabilidade pela atenção pública à saúde para os estados, 2) o processo de continuidade da autonomia político-administrativa de IMSS-Solidariedade, pelo IMSS, sem que ocorresse sua transferência para os estados, como proposto no Programa (Poder Ejecutivo Federal, 1995).

\subsection{Identificação política e as contradições do federalismo mexicano: eficiência e autonomia política?}

As atividades acordadas no âmbito do CNS em 1995 e 1996 foram inseridas no Acordo Nacional para a Descentralização dos Serviços de Saúde, assinado entre o Executivo Federal, 
os governos estaduais e o secretário geral do Sindicato Nacional dos Trabalhadores da Secretaria de Saúde em 20 de agosto de 1996. Deste acordo geral foram derivados os outros Acordos de Coordenação para a Descentralização Integral dos Serviços de Saúde, assinados separadamente com cada governo estadual (Informe de Ejecución PND, 1995) (SSA, Informes de Labores).

Independentemente da vontade política dos governadores, nesta etapa todos os estados foram convocados a participar do CNS e, assim, ingressaram inicialmente na descentralização. Esta não se tratava mais de uma estratégia incremental, como a de Soberón, que visava descentralizar os "palitos fáceis". México encontrava-se num contexto mais avançado de liberalização política e de reestruturação econômica, em que não apenas a pressão internacional mostrava-se mais acentuada, como também o projeto do governo federal mostrava-se explícito no que diz respeito à descentralização para todos os estados restantes. A proposta não se limitava aos serviços de saúde, mas incluía também outras linhas de ação: como desenvolvimento social; agricultura e desenvolvimento rural; meio ambiente, recursos naturais e pesca; comunicação e transportes; turismo; e também a revisão dos critérios fiscais em matéria de distribuição das responsabilidades e descentralização do gasto público federal (Revisão da Lei de Coordenação Fiscal) (PNF).

A decisão da política micro pela descentralização propriamente dita iniciou-se só em 1996, com a assinatura dos Acordos de Coordenação, com cada estado respectivamente. Estes Acordos resultaram na transferência total de bens e materiais da SSA para os estados e no repasse dos recursos orçamentários etiquetados, por meio do novo FASSA. Até dezembro de 1997, a SSA já havia assinado acordos com todos os estados e Distrito Federal, ocasionando a criação de 32 Organismos Públicos Descentralizados (OPDs) em cada uma das entidades federativas. Os OPDs eram os encarregados pela prestação dos serviços de saúde nas entidades federativas, que incluíam a atenção médica, a vigilância epidemiológica e prevenção e controle de enfermidades. Também eram os responsáveis pela administração dos recursos financeiros, humanos e materiais. Só no ano de 1996 foram transferidas 7.400 unidades médicas e administrativas para os estados. Em relação aos recursos, em 1997 foram transferidos 18.190 milhões de pesos, em 1998 estes recursos somaram 12.531 milhões de pesos e em 2000 o valor foi de 21.713 milhões de pesos (SSA, Informes de Labores). 
Nesta nova fase a transferência de recursos ficava menos restrita à arbitrariedade das negociações políticas. A partir de 1997 os recursos financeiros passaram a ser transferidos mediante a aplicação de uma fórmula que considera, entre outros fatores, a taxa de mortalidade, o índice de marginalidade e o gasto com saúde. Com este novo critério, os recursos eram repassados por meio do Fundo de Recursos para os Serviços de Saúde (FASSA), estabelecido pelo Ramo 33 (Recursos Federais para Entidades Federativas e Municípios) do Orçamento Federal. A transferência era efetuada pela SHPC para as Secretarias de Finanças das entidades federativas, que, por sua vez, os repassavam para os OPDs.

Essa transferência da administração, de bens e de recursos para os estados possibilitou de fato um aceleramento no ritmo da descentralização mexicana, iniciada com De la Madrid, e estagnada nos anos de Salinas. Este ritmo mais acelerado, no entanto, não resultou em autonomia fiscal e decisória da política de saúde nos estados. Os limites da redefinição do público ainda mostravam-se maiores que as possibilidades de avanço.

Observe que apesar do acréscimo de transferência de recursos para os estados, o velho centralismo permaneceu na estrutura fiscal e tributária do México, que consiste na concentração da arrecadação tributária no Governo Federal e na pouca flexibilidade orçamentária para estados e municípios arcarem com seu papel de intervenção na estrutura local (OCDE, 1998) (Sempere \& Sobarzo). Esta centralização aplica-se ao caso da saúde porque a descentralização dos serviços foi efetuada sem que se verificasse um incremente na autonomia tributária das entidades federativas. Em vez disso, privilegiou-se a adoção de medidas que ocasionaram o incremento dos repasses "etiquetados”, e, portanto de dependência do orçamento federal.

Além disso, os OPDs não tinham autonomia de decisão em relação ao uso destes recursos transferidos, os quais só podiam ser gastos em programas determinados pela SSA. Os recursos, como dizem os mexicanos, chegavam “etiquetados” e os estados não podiam utilizalos para investir com nova infra-estrutura, empregar mão de obra ou realizar qualquer outro projeto (Arjonilla Alday, 2001) (Abrantes Pêgo, 2001b). Só podiam fazer isto com a aprovação do Governo Federal. Como resultado, a transferência de recursos não se traduziu em incremento da autonomia decisória nos estados sobre a condução da política de saúde. Esta autonomia ficava restrita à parte orçamentária de origem do próprio estado, o que varia grandemente no país. Em todo o país o gasto em saúde de origem estatal manteve-se "próximo 
a 10\% (4,68\% no ano 2000) e não se conseguiu incluir de forma contínua fontes adicionais de financiamento nos estados” (Olvera, 2002, p. 131). No estado de Colima apenas 0,6\% do total do gasto com saúde é de origem estadual (Maldonado, 2003). Em Baja Califórnia Sur este montante era de 4,7\% em 2000 (Olvera, 2002, p.94). A exceção se deu novamente com Tabasco, e com o último ente federativo a entrar na descentralização: o Distrito Federal. Em 2000, os gastos de Tabasco e Distrito Federal com saúde representaram mais de 50\% do total do gasto com saúde destinado à população não assegurada em cada uma destas unidades federativas (SSA, 2003)

A continuidade do constrangimento político-fiscal explica porque a atenção médica pública não era gratuita em nenhum estado do México, apesar de ser dirigida para a população não assegurada e de menor renda. Não apenas a cobrança, como também o incremento no preço do serviço foi um dos meios utilizados pelos estados a fim arrecadar recursos para a saúde. Em Baja Califórnia Sur, por exemplo, o valor da consulta varia entre 10 e 30 pesos (Olvera, 2003).

O ainda baixo nível de identificação política, em especial no que se refere à precária autonomia decisória da política micro, relacionou-se também a dois impasses políticoadministrativos característicos dessa desconcentração politicamente dependente: o conflito decisório que se criou entre as secretarias estaduais e os OPDs, e a questão não resolvida da transferência dos trabalhadores federais. Ao dar poder para as OPDs, o governo Federal gerou um confronto de autoridade entre as duas principais burocracias do setor: Secretarias estaduais e OPDs. Como na maioria dos estados a direção da SES é distinta das OPDs, verifica-se uma indefinição sobre quem decide a política estatal de saúde. Apesar deste papel ser normativamente atribuído à SES é a direção da OPD quem está em contato direto com a SSA (Molina, 2003).

No que se refere à descentralização dos recursos humanos, este é um dos grandes impasses e desafios da descentralização mexicana, os quais permanecem até os dias de hoje, uma vez que o Sindicato Nacional continua a ter uma posição contrária à descentralização (Molina, 2003), em virtude do piso salarial dos estados ser inferior ao nacional (Abrantes, 2001 e 2003). 


\subsection{Identificação administrativa e os dilemas da integração: qual modelo médico público?}

Não se realizou no México a integração do Sistema Nacional de Saúde, mas manteve-se a dualidade do público na atenção médica. A permanência e propagação de um modelo médico dual hospitalocêntrico, de alto custo e sem transparência, deu-se juntamente com o desenvolvimento do novo programa da atenção básica. No que se refere à não integração do sistema, há que se destacar que durante todo o processo "IMSS-solidariedade não foi tocado. Ramón descentralizou apenas o que era da SSA” (Duran, 2003). Em $17^{111}$ estados IMSSSolidariedade continuou a compartilhar a responsabilidade de provisão de serviços com a Secretaria de Saúde, ou melhor, com as secretarias estaduais. Isto pode ser atribuído ao cálculo de minimização de conflito feito pela elite governamental. O intuito era evitar conflitos com os trabalhadores e sindicato da instituição, a fim de não correr o risco de perder o pessoal e, assim, causar um decréscimo na qualidade e na eficiência dos serviços médicos de primeiro e segundo nível do programa IMSS-Solidariedade, localizado em zonas rurais chaves, vistas como zonas de risco de conflitos. O programa alcançava 44,4\% da população não-assegurada nesses 17 estados e 11 milhões de pessoas (22\% indígenas) que habitavam em comunidades rurais marginalizadas” (Perez Cuevas \& Reyes, p. 4), de extrema pobreza.

Há que se ressaltar ainda que a divisão de responsabilidade entre IMSS-Solidariedade e SESs não se mostrou conflituosa, em primeiro lugar, porque diferentemente do período de Soberón, Ramón de la Fuente não procurou por em prática o projeto de integração dos subsistemas de saúde sob o comando da SSA. Em segundo lugar, com a reforma profunda que Zedillo estava promovendo no IMSS, inclusive com a alteração de toda a chefia da instituição, a atenção dos trabalhadores e sindicatos foi certamente desviada para a reforma do próprio IMSS. IMSS-Solidariedade prosseguiu atuando administrativamente de forma autônoma nos 17 estados restantes, apesar de ter que seguir os programas aprovados pela SSA (cabeça do subsetor), e pela SEDESOL. Dentre estes programas, destacavam-se o PAC (PABSS) e o Progresa.

\footnotetext{
${ }^{111}$ Baja California, Campeche, Coahuila, Chiapas, Chihuahua, Durango, Hidalgo, Michoacán, Nayarit, Oaxaca, Puebla, San Luis Potosí, Sinaloa, Tamaulipas, Veracruz, Yucatán e Zacatecas.
} 


\subsection{Identificação social e participação: prestação de contas e transparência?}

Convém ainda ressaltar que todas as etapas da reforma e/ou descentralização no México ocorreram, nesses vinte anos, com pouca ou quase nenhuma participação da sociedade (Cabrero, 2001) (Arjonilla Alday, 2001) (Abrantes, 2001) (Nigenda, 2001), seja na elaboração, seja na implementação. Os conselhos de saúde são órgãos deliberativos, não têm poder de decisão (Arjonilla Alday, 2001) (Abrantes, 2001). Já os grupos de trabalho de base criados pelo PRI, eram organizados como clientela política. O PRI dava dinheiro a esses grupos para ganhar a eleição (Nigenda, 2001). Na maioria dos estados, como mostra o caso de Sonora ${ }^{112}$, apenas a cúpula da Secretaria de Saúde sabia que a descentralização estava correndo.

A descentralização da saúde pública mexicana traduziu-se de fato numa desconcentração política e economicamente dependente, que pode ser qualificada como descentralização propriamente dita em poucos estados, e sobretudo no Distrito Federal e em Tabasco. O processo é tão diverso e heterogêneo quanto o próprio México, e mais especificamente sua política e economia regional ${ }^{113}$. A descentralização promovida por meio do incentivo do pacote básico de fato incrementou, ou melhor, gerou cobertura para população com acesso nulo ou limitado de serviços médicos em zonas rurais, que em 1997 chegou a cobrir 6 milhões de pessoas em 18 estados (OPAS, 1998). Contudo este incremento se limitou a um nível básico de intervenções de saúde, inferior ao primeiro nível de atenção praticado anteriormente nos estados (López-Arellano, 2003) (Santana, 2003). Este incremento também se deu de forma precária em vários estados devido à própria desorganização da burocracia estatal e ao precário abastecimento de medicamentos essenciais em estados que adotaram o PAC (Gómez-Dantes et al., 2001), por exemplo.

Ademais, no decorrer de décadas a aquisição de insumos e equipamentos, tanto no subsetor do IMSS quanto no da SSA, tem sido caracterizada pela corrupção. Tal fato ganhou tornou-se público sobretudo ao final da longa transição de regime e depois da democratização. Não se trata apenas de crise conjuntural, mas de cunho estrutural, ou melhor sócio-cultural (Arellano Gault, 2000). A corrupção envolve o mal uso do dinheiro público, ou mesmo o seu

\footnotetext{
${ }^{112}$ Raquel Abrantes conta que em ocasião de uma pesquisa efetuada em Sonora, os trabalhadores da administração e médicos entrevistados ficaram surpresos ao saberem que ela estava estudando a descentralização da saúde pública no estado (Abrantes, 2001).

113 Para uma análise dos casos de Colima e Baja Califórnia Sur veja, consecutivamente, os trabalhos de Maldonado e Olvera na bibliografia.
} 
desvio para fins privados, gerando efeitos perversos à condição de saúde da população. Ela evidencia-se na socialização de pagamento de comissões, como condição para compra de produtos médicos e hospitalares. Até o período de Zedillo, o processo de construção do público. decidido e implementado de forma não participativa, e sem envolvimento da sociedade, não possibilitou o desenvolvimento de formas menos perversas de socialização no público: como a transparência e a prestação de contas. Ao prevalecerem as velhas formas de socialização, não se verificou uma mudança no entendimento das pessoas envolvidas em relação ao significado do público. Não houve portanto, uma identificação com o público reivindicado como legítimo pela esfera política macro. A análise comparada demonstra que a participação e envolvimento da comunidade e de profissionais de saúde, bem como do político local, mostram-se essenciais na luta contra a corrupção.

Como conseqüência destes efeitos sociais perversos, o processo em construção não altera a imagem que a sociedade tem em relação ao público na saúde, a publicidade negativa milita contra o público e a favor do privado.

\section{Uma nova aliança com a sociedade: autoritaritarismo priista e neoconservadorismo global}

O processo em marcha também tem acarretado mudanças no significado de "público" em relação ao modelo de atenção médica no México. Após sexênios de um pacto social da saúde (com a sociedade não assegurada) sustentado na oferta de serviços de segundo nível sobretudo, o Estado passa a propor uma nova aliança com a sociedade não assegurada: restringida à oferta de um nível básico mínimo inferior, que garante não apenas o incremento da cobertura per cápita, como também minimaliza o custo por intervenção.

O cálculo político aliou-se assim ao econômico, na conformação de uma nova aliança com a sociedade na atenção pública à saúde. A importância do cálculo político pode ser evidenciada, após o avanço da democratização partidária, no fato de todas as correntes políticas do México, seja de esquerda (PRD) ${ }^{114}$, direita (PRI) ou centro-direita (PAN) se mostrarem a

\footnotetext{
114 O PRD, que se encontra no governo do DF, tem adotado uma política de saúde distinta da SSA, implementando políticas condizentes com o marco da saúde coletiva. Sob a direção de Asa Cristina Laurell, a Secretaria de Saúde do DF recusou a seguir o programa de “Qualidade na saúde” do secretario de Fox (Julio Frenk), apresentando sua própria estratégia de gestão. Dentre as políticas diferenciadas em relação ao governo federal e demais unidades federativas, destacam-se o atendimento médico e distribuição de medicamentos gratuitos para idosos (Laurel, 2003) (López-Arellano, 2003).
} 
favor da descentralização e, com exceção do PRD, a favor dos pacotes básicos. O que varia é a forma como se tenta efetuar tais intervenções. Já a relevância econômica, por sua vez, é patente no fato de México ter se convertido em exemplo de sucesso na implementação de políticas sociais antipobreza, como mostram as sugestões feitas pelo Banco Mundial ao governo Lula no primeiro semestre de 2003. Nestas sugestões, enfatiza-se sobretudo o incremento da cobertura, não as problemáticas concernentes à implementação da mesma. Enfatiza-se a focalização, em detrimento da universalização dos serviços de saúde.

Trata-se de mudanças que certamente tiveram uma dinâmica política mais conflitiva e acentuada do que a ressaltada nesta seção do trabalho. No entanto, a ausência de estudos políticos sobre a implementação da descentralização e as limitações de tempo para a realização de uma pesquisa mais aprofundada no México nos impedem, por hora, ir além da análise política aqui efetuada sobre o período de Zedillo. Os documentos oficiais supõem que a descentralização ocorreu perfeitamente em todos os estados. Contudo, como bem assinala uma pesquisadora mexicana, “ela significa o seguinte: que a decisão barra num nível ou no outro, mas segue centralizada” (Arjonilla Alday, 2001). O fato é que contraditoriamente, porém de forma politicamente significativa, a descentralização acentuou-se após a crise de 1994, em meio ao incremento da pobreza e ao conseqüente aumento da demanda de serviços de saúde do subsistema da $\mathrm{SSA}^{115}$. Apesar das problemáticas e limitações envolvidas, bem como ao fato de representar um novo pacto político de atenção limitada à saúde, a descentralização mais exitosa no México foi a da saúde pública (Cabrero, 2001).

\section{Considerações sobre a dinâmica sócio-política da reforma pública: vínculos entre os processos políticos macro e micro}

A redefinição do público no México não se confundiu com o processo de democratização, como no Brasil, mas se relacionou com a reestruturação da economia. Daí o porquê da decisão ter se dado ainda no plano político-administrativo, sem o envolvimento direto ou dos velhos profissionais de saúde (do PRI) ou de atores contra-hegemônicos do setor.

\footnotetext{
${ }^{115}$ Dados da Encuesta Nacional de Salud II de 1994 revelam que 59,5\% da população não possuía nenhum seguro de saúde (público ou privado), mostrando-se assim dependente do sub-sistema de saúde pública da Secretaria de Saúde (SSA) - dirigido para a população não assegurada. Esta condição atingia em média 77,8\% da população nos estados de Hidalgo, Oaxaca, Guerrero e Chiapas. Fatores como baixo nível econômico, nível de renda inferior a cinco salários, usuários não idosos e habitantes da comunidade rural são os que mais caracterizam os usuários dos serviços da SSA.
} 
As decisões foram tomadas pelo Presidente e Ministério da Fazenda juntamente com o thinktank de economia de saúde - nos períodos de De la Madrid e Zedillo -, e pelo Presidente e grupo da Secretaria de Desenvolvimento Social (SEDESOL) no período de Salinas; em resposta às crises desencadeadas pela dupla transição mexicana. O intuito da nova elite política - a cada sexênio - ao redefinir o público na saúde era amenizar as crises e, assim, garantir a permanência do PRI no poder. As redefinições do público foram, portanto, efetuadas a partir da própria esfera política, já articulada com a política global, sem a interferência de movimentos sociais ou de atores políticos ligados a eles. O público reivindicado como legítimo era questionado no final e início de cada sexênio. Tal reforma foi caracterizada por uma recorrente crise de legitimidade e por uma alta descontinuidade do público reivindicado como legítimo pela política macro. Como resultado, redefinia-se um nova política pública a cada governo

O ritmo da implementação do novo público, na esfera política micro, foi condicionado pelo modo como os atores chaves no setor entraram em conflito nos anos de De la Madrid, e depois, nos anos de Zedillo, tiveram seus conflitos "negociados" (no Conselho Nacional de Saúde), evitados (pela dupla estratégia de reforma na saúde), e redefinidos por meio da revalorização do novo federalismo de Zedillo. Tal ritmo se verificou devido à predominância dos valores patrimonialistas e de praticas IMSSsianas em relação aos valores e práticas revindicadas “a partir de cima”. Tratou-se de um ritmo inicial lento, seguido por uma parada com regionalização, e retomado de forma mais acelerada após seis anos, no período de Zedillo. Esta retomada deveu-se a uma articulação entre pressões políticas internas e internacionais, no entanto, dado o caráter não participativo e neoconservador da reforma, foi possível nesta terceira etapa, inserir de forma mais determinante as recomendações da política neoliberal global em relação à saúde.

Quanto ao formato da descentralização, esta se apresentou mais como uma modalidade de desconcentração, com características de descentralização financeira e decisória em poucas unidades federativas. A continuidade da centralização da arrecadação tributária foi uma das marcas deste processo. A autonomia político-decisória, logo de gestão do setor, mostrou-se limitada pela pouca (e nula em alguns estados) autonomia fiscal-financeira das entidades federativas.

De acordo com a literatura hegemônica atualmente sobre processo decisório ou política e reforma de saúde na América Latina (Bossert) (Bossert \& Rosseti) e no México (Funsalud) 
(Soberon Acevedo) (Frenk) (Nigenda) (Gonzalez-Block), a reforma mexicana apresentou um baixo nível de viabilidade política, em virtude das divergências de interesses, conflitos e pouca capacidade institucional. Como vimos neste capítulo, o ritmo lento e fracassos na implementação mostraram-se como um problema de identidade (ou melhor, não-identidade), que envolve não apenas interesses e capacidade institucional, mas também valores. A baixa viabilidade política se traduziu de fato em rejeição da autoridade da política pública (Leis; valores e diretrizes) reivindicada como legítima, tendo em vista 1) o não-envolvimento dos profissionais de saúde, 2) o gradual envolvimento dos políticos, 3) a não participação da sociedade, 4) o conseqüente alto nível de reprodução de velhos padrões de socialização (como ineficiência e precária organização administrativa), bem como a consecutiva reprodução de efeitos sociais perversos. Estes resultados paradoxais à autoridade da política pública reivindicada na esfera macro, evidenciados com o descontrole epidemiológico e a publicidade das fraudes e corrupção, foram tornados públicos no decorrer da distensão política e a cada fim de governo. Tais efeitos associaram-se às situações de crise política e econômica do país, evidenciando não apenas a crise de autoridade e legitimidade da política de saúde, mas da própria autoridade do PRI enquanto poder político.

Foi neste contexto de crise estrutural e conjuntural, revivido a cada fim/início de sexênio, que a descentralização da saúde foi interrompida nos anos de Salinas - sendo substituída por uma regionalização patrimonialista do domínio público-estatal (nas três subesferas do poder micro: política, administrativa e da sociedade civil) -, e, após seis anos, retomada no período de Zedillo. Não se tratava apenas de uma questão de "viabilidade”, mas de imposição de um novo conceito e significado para o domínio público-estatal na saúde. A questão da não-viabilidade, portanto, se traduziu como uma problemática de não-identidade (do político, administração e sociedade civil) e conseqüente questionamento da legitimidade de uma política pública redefinida mormente "a partir de cima”.

As recorrentes crises de legitimação da autoridade da política pública de saúde em construção, reivindicada como legítima pela política macro priista, evidenciam que as reformas de tipo não-participativo, logo conservador, efetuadas sobretudo a partir dos interesses inseridos na esfera política macro, sem a influência direta de mobilizações sociais, ou sem ou com pouca participação dos interesses da esfera política micro, resultam num longo processo de construção-desconstrução: guiado por um alto grau de conflitos e caracterizados por um alto 
nível de descontinuidade. O aprendizado da elite priista com a construção política mostrou-se gradual - como revelou a estratégia de consulta a governadores adotada apenas por Zedillo -, no entanto, o aprendizado com a construção social na implementação foi quase nulo. O ritmo perverso da reforma não favoreceu a construção de novas formas de socialização na política micro e na atenção médica, mas favoreceu a predominância das práticas políticas patrimonialistas e das formas estado-cêntricas IMSSIanas na construção do novo domínio público. Neste sentido, o fato de ter ocorrido o retomo e o aprofundamento da descentralização (adotada em todos os estados), nos anos de Zedillo, não significa que "a participação social possivelmente não se mostrará mais como requisito necessário para incrementar a viabilidade política das reformas de segunda/terceira geração” (Kaufman \& Nelson, 2003).

Compreendemos que o nível de identificação será maior ou tenderá a aumentar quando a decisão sobre a política pública que se pretende legitimar, se traduzir na legalização de um processo que, em alguma medida, já ocorre na esfera política micro e na esfera social. No caso mexicano, vimos que os níveis de identificação da política micro foram demasiadamente baixos no decorrer de todo o processo (1984-2000), em especial quando comparados com os níveis de identificação da reforma brasileira (Capitulo 5). O ainda pequeno incremento ocorrido de forma sócio e politicamente perversa, nos anos de Salinas - com a regionalização de PRONASOL -, não possibilitou um acréscimo significativo do nível de identificação. Esta manteve-se no nível baixo (oscilando entre os níveis Baixo1-Baixo2-Baixo1). Ademais, o maior nível de identificação verificado já nos anos de Zedillo, em relação sobretudo ao extremo fracasso da política de descentralização de De la Madrid - que oscilou entre o nível Baixo1 e Nulo -, embora mais significativo, não se traduziu ainda em alta aceitação da política macro, mas apenas numa rejeição mais baixa, chegando ao nível Baixo4. De 1994 a 2000, México encontrava-se apenas no primeiro tempo de "viabilidade política" da reforma, concretizado tão-somente após 16 anos de uma reforma elaborada “a partir de cima”.

Mais além da viabilidade política, o caso mexicano assevera a necessidade de se compreender os avanços e dificuldades das reformas como um processo de pressões e de identificação, logo, de legitimação em (lenta) construção. Neste processo, os “ismos” atualmente hegemônicos nas Ciências Sociais (como o individualismo, economicismo, o politicismo e o institucionalismo, entre outros) deveriam ser reinterpretados em termos relacionais, como probabilidades de comunicação/inter-relação com uma sociedade e cultura- 
política específica, portadora de interesses e de identidades. O nível do envolvimento do político e do funcionário público/médico e da sociedade, por contribuírem para modificar o entendimento destes atores sobre o significado de público, gerando novas lutas e formas de socialização, mostram-se determinantes para a compreensão das dificuldades e avanços na realização das reformas: na década de 80, na década de 90 e, com grande probabilidade, nas décadas a seguir.

Considerando que México inaugurou um novo tempo na política após a eleição presidencial de 2.000. Qual é a probabilidade política de se dar continuidade, na democracia, ao projeto/programas de descentralização de Zedillo e de se superar os desafios econômicofiscais e político-culturais na redefinição da política pública? Se e em que termos haverá um aceleramento do processo de descentralização, alcançando os municípios?

Em países de extrema desigualdade social e onde as instituições de seguridade social são ou foram hegemônicas na atenção pública à saúde, a implementação de um novo domínio público para a população não-assegurada implica não apenas numa construção política, mas também numa construção social. Em diferentes países e em processos políticos de distintos ritmos e formatos, tal tarefa requer não apenas engajamento político, como também identificação social. Os novos valores de gerenciamento/administração pública e as novas concepções de saúde (coletiva ou individual) devem ser transmitidos e aprendidos (internalizados) por políticos, funcionários públicos, médicos, enfermeiras, e pacientescidadãos. Desta forma, a autoridade da política pública reivindicada como legitima pela política macro teria maior possibilidade de ser reconhecida e implementada e, conseqüentemente, se mostraria menos sujeito a rupturas. A probabilidade de aceitação da política pública mostra-se extremamente dependente dos padrões de socialização vigentes no decorrer da implementação da política. Estes processos de identificação social apresentam e tenderão a apresentar significados plurais e naturezas distintas entre os países e dentro deles. Ainda, tais processos continuarão a ter um ritmo lento e um formato não limpo (“not clean”), contrário à alternação desejada e implícita nos modelos economicistas de desenho de políticas de públicas, amplamente utilizados pelos formuladores de políticas em todo o mundo.

Vejamos agora como se deu a construção da política pública de saúde no Brasil, de Sarney a Cardoso (1985 a 1998). 


\section{PARTE III - Decisão política e identidade na construção da política pública de saúde: o processo de legitimação do Sistema Único de Saúde no Brasil (1985-1998)}

\section{Introdução}

Nos anos setenta a questão da integração social, e mais especificamente no que diz respeito ao acesso à saúde, mostrava-se politicamente significativa no contexto da transição política mexicana e brasileira, como vimos. No Brasil, a integração política na saúde seguiu uma rota democrática específica, com a inserção de alguns atores políticos contra-hegemônicos na esfera política, os quais passaram a lutar para a efetivação do acesso à saúde. O Sistema Único de Saúde (SUS) foi fruto desta luta democrática singular, mobilizada socialmente, a partir de baixo, em algumas cidades, também articulada na esfera política autoritáriaconservadora, a partir de cima. Esta dupla atuação, favorecida pela redemocratização dos anos 80, mesmo que limitada a alguns estados e cidades, possibilitou a continuidade desse processo de construção do público na saúde no Brasil. O novo sistema público recebeu a atribuição de direito social, ou melhor, de direito à saúde, bem como teve suas diretrizes e princípios legalizados na Constituição de 1988. Dentre as diretrizes que deveriam orientar a organização e funcionamento do novo SUS encontravam-se a descentralização, a integralidade da assistência e a participação da comunidade. A operacionalização dessas diretrizes deveria ser fundamentada nos princípios de universalidade, igualdade e eqüidade.

Apesar do processo político do SUS não ter sido interrompido em termos nacionais logo após a institucionalização do novo marco legal, como no caso mexicano, os valores e diretrizes criados em 1988, e legislados nos anos seguintes, ainda não foram plenamente realizados e, portanto, efetivamente reconhecidos e legitimados na realidade política micro e social brasileira, nesses 16 anos de construção. A efetivação do acesso universal, embora realizada por meio de uma ampla descentralização dos serviços de saúde, não eliminou as desigualdades na atenção da saúde, nem resultou na efetivação de um modelo médico integral e eqüitativo. A integralidade da assistência mostrou-se constrangida por conflitos e práticas políticas clientelistas e patrimonialistas, como também por práticas administrativas e médicas 
legadas do modelo hospitalocêntrico e privatista do INAMPS. Já a eqüidade ${ }^{116}$ na alocação de recursos dos serviços públicos, na saúde, encontrou-se igualmente limitada pela forma como conflitos de valores e interesses e velhas práticas políticas, ocorridos em tempo de estabilização econômica, deram novos formatos ao padrão de dependência econômico-fiscal, logo política, caracterizador das relações do federalismo brasileiro.

O propósito deste capítulo é estudar o processo de construção do SUS como um processo de legitimação da autoridade de uma política pública (Leis; valores e diretrizes), construída na política macro e micro e na sociedade, em distintos governos (de Sarney, Collor, Itamar e Cardoso) e tempos de democracia com estabilização econômica. O problema da legitimação da autoridade da política pública será investigado ao verificarmos em que termos os valores e diretrizes regulamentados no processo decisório, na esfera política macro, em cada período de governo e tempo de transição político-econômica, foram de fato internalizados e realizados e, assim, reconhecidos como legítimos no processo político de decisão e implementação na esfera micro.

\section{Questões e hipóteses: a construção da política pública de saúde no Brasil}

A pergunta central que propomos é a seguinte: de que forma os atores políticos e sociais envolvidos no processo político do SUS, em distintos períodos do processo de construção na esfera política micro (estadual e/ou municipal) se identificaram com os valores e políticas produzidos/regulamentados na esfera política macro? A fim de respondermos à pergunta proposta, analisaremos primeiramente o processo decisório macro e, em seguida, o de decisão e implementação micro do SUS, em cada período. Para então, na conclusão, termos uma visão de conjunto da dinâmica e das problemáticas políticas relacionadas ao processo de legitimação do SUS de 1985 a 1998.

\subsection{Sobre a participação no processo decisório macro}

Na análise do processo decisório macro, pretendemos verificar em que termos o movimento sanitário, com a democratização, continuou tendo lugar de destaque como interesse contra-hegemônico neste processo de redefinição. Tratava-se do período em que representantes

\footnotetext{
${ }^{116}$ A equidade na alocação de recursos relaciona-se, de formas distintas entre os países, a outras problemáticas da eqüidade (como a eqüidade no gasto, no acesso e na qualidade dos serviços públicos)
} 
do movimento tiveram que negociar seus interesses não apenas com o setor privado e burocracia do INAMPS, mas também com a classe política partidária, representativa dos interesses daqueles velhos atores no novo Congresso. Este embate ocorreu em vários espaços da política, que se tornaram politicamente mais permeáveis e plurais, integrando representantes políticos do movimento e/ou sendo influenciados pelo movimento, e em alguma medida também influenciados pela realidade política das AIS/SUDS já em construção na esfera micro.

Embora de forma distinta do período de Sarney, o movimento sanitário continuou influenciando a esfera política e participando do processo decisório de regulamentação do SUS de Collor a Cardoso (1990-98). A nossa hipótese é que essa participação diferenciada deve ser atribuída 1) ao surgimento de uma coalizão política hegemônica identificada política e simultaneamente com o neoliberalismo e democratização, adotando políticas de estabilização macroeconômica e, conseqüentemente, de contenção de gastos públicos; 2) e ao fato de ter ocorrido mudanças qualitativas no movimento sanitário, caracterizadas pelo esvaziamento (Rodriguez Neto, 2003) ou despolitização do movimento (Paim) (Pinheiro, entrevista 2003) ${ }^{117}$. Neste contexto, o Ministério da Fazenda e o Ministério da Saúde e Conselho Nacional de Saúde, além do Ministério da Previdência e Congresso, apresentaram-se, na política macro, como principais espaços institucionais de luta no processo de regulamentação do SUS nos anos 1990. As Conferências Nacionais de Saúde não tiveram mais a mesma capacidade de mobilização político-social, nem o mesmo peso político da $8^{\mathrm{a}}$ Conferência, ocorrida no princípio da redemocratização. Daí o porquê da questão do financiamento e, logo, da redistribuição de recursos, ter se tornado o foco deste embate.

Nessa fase de regulamentação do SUS (1990-1998), de Collor a Cardoso (1 ${ }^{\circ}$ governo), verificou-se uma influência progressiva da ortodoxia econômica sobre a construção política do SUS. Embora de forma distinta, a coalizão política tentou reverter/desacelerar o processo de descentralização e/ou redefinir a forma como se daria a realização do direito constitucional à

\footnotetext{
${ }^{117}$ O movimento tornou-se mais complexo, com o envolvimento de novos atores, acarretando o "esvaziamento de uma ou outra entidade e o fortalecimento de outras, criando às vezes até confusões a respeito de se estaria ou não havendo retração ou não do movimento. Na verdade, pode-se dizer que seu ponto máximo de organização foi por ocasião da $8^{\mathrm{a}}$ Conferencia Nacional de Saúde em 1986 e, após um arrefecimento, parece encontrar uma nova forma de atuação menos corporativa, mais política, através da Plenária da Saúde” (...) Além disso, o movimento “também nunca teve tão imiscuído com o poder, desde o nível federal até o municipal”, (...) limitado pelas possibilidades econômicas e técnicas do setor, quando a população começa a exigir respostas concretas das instituições e quando a oposição conservadora 'aposta' na incapacidade de se darem respostas eficazes e eficientes” (Rodriguez Neto, 2003, p.126).
} 
saúde. Tratou-se de iniciativas díspares, as quais resultaram ou em fracasso ou na reorientação do processo em curso. Contudo, não desencadearam uma ruptura com o processo em construção, ou uma mudança drástica do mesmo, como no México. A nossa hipótese é que o caráter de continuidade do SUS, em comparação com o caso mexicano, deve ser atribuído à atuação de representantes políticos do movimento sanitário, na esfera política macro, e à maior contrapartida da permeabilidade do SUS na esfera social e política micro. Os valores e diretrizes reivindicados como legítimos, a cada fase da construção política (das legalidades do SUS), mostraram-se por certo ainda extremamente contraditórios em relação à realidade política micro e social brasileira, porém, do ponto de vista comparativo, revelaram-se menos contraditórios do que na construção mexicana.

\subsection{Sobre a identificação no processo político micro}

Na análise do processo micro de decisão e implementação da reforma, pretendemos ressaltar em que termos a esfera política micro identificou-se com os valores e diretrizes formuladas pela política macro, no decorrer da construção do SUDS e SUS, em distintos períodos de governo e tempos de influencia da política global (Capítulo 3). A nossa hipótese é que, a despeito dos vários problemas e efeitos perversos vindos à tona no decorrer da construção do SUS, verificou-se, na comparação com México, uma identificação mais positiva e politicamente significativa da esfera política micro (em suas três sub-esferas: política, administrativas e social) em relação às decisões produzidas no nível macro nacional.

Na conclusão, por fim, pretendemos utilizar o processo de reforma de quinze anos, realizado em diferentes governos e tempos de democratização e influência do domínio da política global, a fim de verificar qual a relação existente entre padrão de participação direta da decisão (PDD) e nível de identificação com a política macro no Brasil, de Sarney a Cardoso. A nossa hipótese geral é que há uma correlação direta positiva entre escopo da participação e nível de identificação, ou seja, quanto mais amplo ou plural o escopo da participação no processo decisório, mais elevado mostra-se o nível de identificação com a política pública (valores e diretrizes) decidida na esfera macro. 


\section{Capítulo 7 - A construção da reforma pública de saúde no princípio da redemocratização: o período do governo Sarney (de 1985 a 1990)}

“Diretas Já!”

(grito representativo da expectativa dos brasileiros na transição de regime)

A nova coalizão política civil ascendeu ao poder do governo federal por meio de uma eleição indireta, realizada no chamado Colégio Eleitoral. Tratou-se de uma transição democrática pactuada dentro da própria esfera política e, mais especificamente, entre os atores políticos oligárquicos dominantes no Congresso Nacional. A oligarquia que ascendia ao poder após o período autoritário legitimava-se, perante a sociedade civil, pela intenção de executar políticas que resultassem na redução da pobreza e da desigualdade no País. Politicamente, o retorno da democracia - mesmo que ainda pactuada - caracterizou-se como um tempo de renovação da esperança da população nos partidos e na classe política. No que diz respeito à política pública de saúde, a expectativa da sociedade era de que a cidadania social pudesse ser ampliada para a população em geral, por meio da institucionalização do acesso a políticas sociais mais igualitárias.

A mesma oligarquia política regional que havia contribuído, nos períodos anteriores, pela predominância de padrões autoritários e socialmente perversos de decisão em relação às políticas públicas de saúde no Brasil, apresentava-se como liderança política disposta a "tudo pelo social”. Como lembra-nos Weffort (1994), “raras vezes na história de um país houve tanta ansiedade para vincular o político e o social, e, ao mesmo tempo, tanta dificuldades em fazer com que esta vinculação produzisse resultados práticos” (Weffort, 1994, p.30). De forma que a questão do por que e como foi possível criar uma política de saúde de caráter universal, adquire significado eminentemente político, ou melhor, sócio-político na transição democrática brasileira. Há que se verificar, no entanto, se e em que termos o retorno da democracia e, mais especificamente de uma “democracia de conflito" (Weffort, 1994) - caracterizada pela desigualdade social e divisão da sociedade e pela ausência de consenso na política sobre o desenvolvimento social igualitário -, possibilitou a institucionalização do direito à saúde e a extensão da cidadania social na periferia do capitalismo em tempo de globalização econômica. 
Nosso argumento é que a criação do SUS no início da Nova República constituiu-se num caso paradigmático de reforma no setor público de saúde na América Latina, em especial em comparação com o caso mexicano. As diretrizes do SUS, como negociadas na esfera política macro, obteve o apoio da elite no poder porque se apresentava como instrumento de justificação do exercício da autoridade política reivindicada pela classe política naquele momento. A execução prática da política pública (valores e diretrizes) reivindicada como legítima seria dificultada pela inexistência de fatores políticos e sociais que poderiam ter possibilitado o desenvolvimento de uma democracia social, como ocorreu nas velhas democracias. Estes fatores ainda em lenta construção na periferia em desenvolvimento podem ser exemplificados 1) pela inexistência relativa de uma sociedade mais homogênea em termos de distribuição de renda, 2) pela permanência da desigualdade sócio-econômica regional no país, 3) pela dependência do mercado econômico internacional e 4) pela vigência do caráter extremamente instável do consenso político (por parte dos representantes e/ou decisores políticos) em relação a políticas de desenvolvimento social, logo re-distributivas e extensivas a uma parcela maior da sociedade; isto é de natureza e escopo mais amplos (Linz e Stepan, 1999) (vide Capítulo 1). Tais fatores compreenderam obstáculos políticos para a ampliação da cidadania social e realização efetiva do direito à saúde universal e com integralidade na atenção no Brasil, bem como nas novas democracias em construção no mundo.

De forma distinta do período de lenta transição de regime político, concernente ao governo de De la Madrid, no México, tivemos no Brasil o surgimento de novos atores contrahegemônicos na esfera política - no nível macro e micro -, e de novos atores e movimentos sociais na esfera social, reivindicadores de mudança no domínio da política pública-estatal de saúde. A coalizão política civil que se formou em torno da Presidência identificava-se antes com uma política econômica heterodoxa, ainda com tendência ao desenvolvimentismo, pois a restrição ortodoxa na alocação dos recursos da economia, ao dificultar ou bloquear a distribuição de recursos pela política nacional, inviabilizaria politicamente a possibilidade de atendimento das demandas sociais e dos interesses políticos municipalistas e estaduais (destes sobretudo), revalorizados no período de transição política brasileiro. Ademais, o processo de democratização da representação política na esfera política macro, ao tornar a representação mais plural e conflituosa, bloqueou a possibilidade de reestruturação da economia com base 
nas recomendações neoliberais, já em voga no cenário internacional ${ }^{118}$. De forma que foi em meio a uma transição política marcada pelo retorno da democratização política com desenvolvimentismo que a reforma da saúde entrou na agenda do governo nacional. Verificouse, neste contexto, uma mudança qualitativa na interação existente entre esfera social e a esfera política: em especial no que se refere ao processo decisório relacionado à política pública de saúde.

Vejamos então em que termos essa articulação impar na História brasileira, entre a esfera social e política, com a influência direta do movimento social em saúde e com a participação de atores contra-hegemônicos no processo decisório da política macro, ocorreu e se mostrou essencial para o entendimento do por que e como se deu a inserção de uma proposta radical de mudança no setor público de saúde na agenda política: o qual será legalizado e reivindicado como legítimo pela política macro.

\section{Processo decisório participativo na redefinição da política pública de saúde}

O processo decisório da reforma sanitária mostrou-se bem complexo e, até mesmo, contraditório. Para os representantes do movimento sanitário, tal processo ainda se mostrava em construção nos anos 2000. Contudo, ao possibilitar não apenas a realização de uma mobilização popular, bem como a inserção de atores contra-hegemônicos na esfera política macro (no MPAS/INAMPS e Congresso Nacional), o princípio da redemocratização apresentou-se como um tempo de oportunidade para a inclusão das propostas reformistas de saúde na agenda política macro, e de conseqüente definição dos marcos institucionais que deveriam nortear a construção da reforma sanitária.

Em comparação ao caso mexicano, os fundamentos teóricos e legais da reforma sanitária brasileira, apesar de terem surgido de um duplo processo de construção política, efetuado na esfera social e na política, este processo mostrava-se ainda mais determinante da esfera política do que na da sociedade. Na esfera política macro verificou-se a decisão por

\footnotetext{
118 No entanto, muitos dos princípios e diretrizes de políticas hegemônicos no receituário ortodoxo já se encontravam presentes nas reflexões e diagnósticos dos economistas brasileiros sobre o processo de hiperinflação vivido na década de 1980. Refiro-me à teoria da inflação inercial e da influência que esta teve na elaboração dos consecutivos choques heterodoxos dos anos 80, isto é, nos diversos planos econômicos adotados no período. Ademais, as dificuldades de implementação destes planos heterodoxos e seu conseqüente aprendizado e impacto político (acirrando a crise de governabilidade do país) prepararam o caminho para a elaboração do plano de estabilização, o Plano Real
} 
novas políticas públicas e a institucionalização das bases legais do novo Sistema, enquanto na esfera da sociedade deu-se uma democratização limitada (a municípios/estados e espaços dentro de tais municípios/e estados, e a representantes sociais e políticos do setor em espaços nacionais sobretudo) do debate púbico sobre os princípios e diretrizes que foram legitimados pela política macro. Tal processo de construção pode ser caracterizado por três etapas distintas, porém inter-relacionadas, isto é: i) por uma mobilização político-social do setor no nível nacional, na ocasião da $8^{\text {a }}$ Conferência Nacional de Saúde; ii) pela negociação política em torno da reforma administrativa e decisão pelo SUDS na esfera política macro do MPAS e INAMPS e iii) pela negociação política da legislação da saúde por representantes políticos na Assembléia Nacional Constituinte (ANC). Em cada uma das etapas vieram à tona, consecutivamente, três estratégias distintas de reforma sanitária.

\subsection{A VIII Conferência Nacional de Saúde como fórum participativo}

A Oitava Conferência Nacional de Saúde, realizada entre 17 e 21 de março de 1986, foi reconhecida de forma unânime como um marco do movimento social na saúde e da reforma sanitária brasileira (Arouca, 1988) (Paim, 1988) (Minayo, 2001) (Silva, 2001) (Elias, entrevista 2003) (Mehy, entrevista 2003). Arouca relata-nos porque o movimento sanitário decidiu realizar tal manifestação popular na saúde:

“O marco era transferir o Inamps para o Ministério da Saúde, e qualquer reforma deveria começar pela integração. Mas havia um problema: a Saúde estava na mão de um conservador e a Previdência com a oposição. Até que, na calada da noite, o Carlos Santana consegue um decreto que autoriza o Sarney a passar o Inamps para o Ministério da Saúde. Waldir Pires então veta o decreto, dizendo que 'o Inamps é um patrimônio dos trabalhadores e que por isso essa decisão deveria ser participada a eles'. Pensamos em fazer isso convocando uma Conferência. Mas, na época, as Conferências de Saúde eram espaços burocráticos, onde os temas e os resultados já estavam pré-definidos. Propusemos então convidar a sociedade para discutir a questão e realizar uma conferência com a participação de 50\% de usuários” (Arouca, 2002, p.4).

Observe que a decisão pela $8^{\mathrm{a}}$ Conferência consistiu não apenas em reação política ao próprio processo da política macro, visto como conservador e contrário à reforma proposta pelo movimento sanitário, como apresentou uma natureza distinta em relação às Conferências anteriores: assumiu o formato de uma mobilização social mais efetiva em relação à esfera 
política. Seu objetivo era legitimar o processo de construção do novo Sistema de Saúde. Nascimento (2004) conta-nos que "Mais de quatro mil pessoas participaram da Conferência, em jornadas de discussão que duraram até 14 horas. Destes, mil eram delegados escolhidos e/ou indicados pelas instituições, organizações e entidades como seus representantes” (Nascimento, 2004). Dentre estas entidades, destacava-se o CONASS (Conselho Nacional de Secretários Estaduais de Saúde) e o movimento pela municipalização na saúde, formado praticamente por secretários municipais de saúde. Ademais, “O comparecimento do Presidente José Sarney e de várias personalidades políticas como Waldir Pires (Ministro da Previdência), Carlos Santana (Saúde), Ulisses Guimarães (Presidente do PMDB e mais tarde da Constituinte), Pimenta da Veiga (Líder do Governo) e Almir Pazzianoto (Ministro do Trabalho) conferiu ao evento legitimidade política inquestionável” (Nascimento, 2004) ${ }^{119}$.

De acordo com Sérgio Arouca (1988), “nunca houve um debate tão amplo no setor saúde” (Arouca, 1988, p.49). A discussão deu-se praticamente sem a interferência do setor privado, contrário à proposta de reforma do movimento sanitário. Isto porque, em algum momento, o setor privado - representado pela Federação Brasileira de Hospitais (FBH), e pelas associações estaduais, bem como pela a Federação Nacional de Estabelecimentos de Serviços de Saúde (Fenaess) - se retirou maciçamente da Conferência (Elias, entrevista 2003). De acordo com Mansur José Mansur ${ }^{120}$, “Todos os dirigentes de entidades foram unânimes em afirmar que as decisões principais já estavam tomadas e, inclusive, o relatório final já estava escrito antes mesmo de os trabalhos haverem começado” (Pereira, 1996, p.13).

Foi neste fórum de discussão que se consolidou uma agenda radical de mudança para a política de saúde brasileira, chamado de “o ante-projeto da reforma” (Arouca, 1988). De acordo com este ante-projeto, a reforma sanitária brasileira deveria possibilitar o surgimento de um sistema de saúde universal, igualitário, participativo, descentralizado e com integralidade na atenção médica (Ministério da Saúde, 1988) (Rodriguez Neto, 1997, p.70). Há que se destacar ainda que o relatório final da Conferência propôs uma mudança radical no significado do conceito de saúde.

\footnotetext{
${ }^{119}$ Veja o texto História da $8^{a}$ Conferência de Álvaro Nascimento, coordenador do RADIS/ENSP/FIOCRUZ, In: http://www.fiocruz.br/histconferencias/conferencia8.html , acesso em 23/04/2004.

${ }^{120}$ Presidente da Associação dos Hospitais do Rio de Janeiro e vice-presidente da Federação Brasileira de Hospitais - FBH.
} 
“A saúde não é um conceito abstrato. Define-se no contexto histórico de determinada sociedade e num dado momento de seu desenvolvimento, devendo ser conquistada pela população em suas lutas cotidianas. Em seu sentido mais abrangente, a saúde é a resultante das condições de alimentação, habitação, renda, meio ambiente, trabalho, transporte, emprego, lazer, liberdade, acesso e posse da terra e acesso aos serviços de saúde” (Ministério da Saúde, 1987).

Com a $8^{\mathrm{a}} \mathrm{CNS}$, parecia verificar-se - na periferia do capitalismo - a realização de um fato inédito: a construção de um “espaço público” de debate (na acepção burguesa habbermasiana do termo), no qual se concretizava uma proposta "politicamente autônoma" (autônoma da esfera política) de mudança no sistema de saúde vigente. Nesta acepção normativa do significado de público, tal proposta teria compreendido e incorporado as demandas e anseios do público brasileiro em geral. No entanto, tratou-se de um debate público limitado a representantes sociais do setor e sobretudo a representantes politicamente inseridos (no nível macro e micro) do setor, correspondendo e propiciando, por fim, a viabilização política de aspirações político-ideológicas do núcleo politicamente hegemônico do chamado “movimento sanitarista”, inserido em algumas instituições da esfera política macro na ocasião.

Carlos Pereira define bem as principais diretrizes desta proposta:

“ (...) tinha como princípio norteador a questão da unificação do setor saúde no âmbito federal em um único organismo que condensasse tanto as funções de assistência médica individual, quanto as ações de saúde coletiva, encerrando a eterna dicotomia existente entre esses dois setores. Ela se aproximava de uma visão global de planejamento das ações de saúde de forma centralizada, como também dos desdobramentos institucionais nas esferas estadual e municipal no sentido da viabilização do comando único nas três esferas de governo. Representava, ainda, uma antiga aspiração do movimento sanitarista, tendo no Ministério da Saúde e na Fiocruz os principais locii institucionais de propagação dessa estratégia. Era representada pelo PCB, nas figuras de Eleutério Rodrigues Neto, então secretário-geral daquele Ministério, e de Sérgio Arouca, na época presidente da Fiocruz”121 (Pereira, p.8).

Ademais, foram das discussões realizadas na $8^{\mathrm{a}}$ Conferência que surgiram: 1) a proposta do Sistema Único e Descentralizado de Saúde (SUDS) - que deveria aprofundar as AIS, e 2) a proposta de formação da Comissão Nacional da Reforma Sanitária (CNRS). Esta

\footnotetext{
${ }^{121}$ Grifos meus.
} 
organizou um documento com base nas discussões realizadas na Conferência, o qual serviu de referência no embate concernente à saúde na Assembléia Nacional Constituinte (ANC).

Este fórum de debates, no qual se revelou a $8^{\mathrm{a}}$ Conferência - fruto da atuação política de representantes inseridos do movimento sanitário, articulados com o demais representantes sociais e políticos no território nacional, fato devidamente documentado pela literatura sobre o SUS, e, aliás, devidamente assinalado desde o início deste trabalho como dupla porém ainda limitada participação (na esfera social e política) mostrou-se singular na História brasileira. Tal fato, no entanto, não é condição suficiente para a construção política e social de uma reforma democrática audaciosa, a qual pode ser interpretada como revolucionária em reciprocidade à realidade histórica política e social do nosso país: onde predomina uma política de matriz cêntrica, vis-à-vis as relações estado/sociedade, e em que a construção do domínio público-estatal de saúde se deu por meio da Previdência, com a inserção da medicina privada no setor público-estatal e, com a realização de práticas contrárias à saúde econômico-financeira e política do setor público-estatal de saúde. Ressaltamos aqui a necessidade de se trazer à tona a realidade dos interesses ideológicos e políticos que se apresentaram como compromissados ou não com a reforma democrática da saúde no Brasil. Esta inter-relação entre ação política realizada na esfera social e a ação política executada na esfera política, mostra-se essencial para a compreensão do como foi possível, no Brasil, consolidar um marco legal democrático na saúde, em meio à oposição vigente por parte de representantes da elite política e do setor privado do setor.

\subsection{Reações políticas à VIII Conferência: o cálculo da elite política e a oposição do setor privado}

A presença de políticos do primeiro escalão na Conferência, bem como de representantes da CUT, por exemplo, não significava que estes atores estivessem compromissados com a reforma como proposto pelo movimento. A identificação da elite política com a Conferência pode ser atribuída ao alto nível de mobilização social alcançado pelo próprio movimento, e ao conseqüente cálculo político realizado, de sustentação do poder legitimado nas urnas ou no Colégio Eleitoral. Há que se ressaltar ainda que a elite política da CUT e do Partido dos Trabalhadores não se encontravam na Conferência, apenas técnicos ligados ao setor saúde da instituição (Elias, entrevista, 2003). Como vimos (Capítulo 2), o setor trabalhista formal tem acesso ao setor médico privado, sendo um dos responsáveis pelo 
crescimento deste setor no país desde o final dos anos 70. Carlos Pereira lembra-nos ainda que “o Ministério da Previdência, embora tenha bancado financeiramente sua realização, participou de forma tímida e até o último momento” (Pereira, p. 12). O compromisso político destes atores com o tipo de público a ser criado, na saúde, virá à tona no decorre da luta travada por seus representantes no processo decisório do SUDS e na Assembléia Constituinte.

Torna-se preciso considerar ainda que a saída do setor privado da Conferência deveu-se ao fato das propostas e temáticas discutidas no plenário terem, de forma unânime, convergido para o intento de se criar um sistema único, estatal, descentralizado e de acesso universal de saúde. Houve aí a concretização da percepção, por parte do setor privado, do risco que o privado correria com a estatização do público do qual se servia. Em decorrência dessa percepção, o setor privado passou a se articular politicamente de forma mais eficaz após a $8^{\text {a }}$ CNS. Realizaram, por exemplo, o I Congresso de Entidades Não-Governamentais do Setor Saúde, reunindo os prestadores de serviços médicos privados. Tal Congresso "foi organizado pela Fenaess, FBH e Abramge com o objetivo de reafirmar a importância dos serviços de saúde não-governamentais a despeito de inúmeras pressões do INAMPS e como uma resposta à altura contra as conclusões da $8^{\mathrm{a}}$. CNS, na qual manifestantes previamente escolhidos apoiaram a idéia preestabelecida da estatização da medicina e da assistência hospitalar no Brasil” (Cohn, Marsíglia e Barata, 1990). Ademais, sobretudo após 1987, quando Sarney renovou compromissos com uma facção mais conservadora da política brasileira, o setor contratado do INAMPS também passou a ser articular de forma mais eficaz na esfera política macro.

Vejamos como os interesses da elite política brasileira vieram à tona, logo após a $8^{\mathrm{a}}$ CNS, no processo decisório do SUDS e, assim redefiniram a proposta da reforma do movimento sanitário.

\subsection{O processo decisório macro do SUDS}

A decisão pelo SUDS resultou de um processo de negociação entre a liderança do Ministério da Previdência e Assistência Social (MPAS) e do Instituto Nacional de Assistência Médica e Previdência Social (INAMPS). Desde a abertura política, o MPAS e, em especial, o INAMPS, que funcionaram como atores políticos durante o período mais repressivo e centralizador dos governos militares, haviam se convertido em arena política onde os interesses em conflito passaram a se enfrentar (Lucchessi,1995) (Escorel, 1999). Com a 
redemocratização, o movimento sanitarista chegou a ocupar a posição mais alta na hierarquia da administração pública INAMPSiana. Hésio Cordeiro, um dos principais acadêmicos da Medicina Social brasileira, era o então Presidente do INAMPS, e foi uma das figuras principais na elaboração do Sistema Unificado e Descentralizado de Saúde (SUDS). Este foi influenciado pelas pressões exercidas na 8a Conferência e a expectativa, por parte dos atores mais progressistas do movimento sanitário, era de que a nova política pública de saúde pudesse levar em consideração as propostas daquele fórum popular.

No entanto, ao assumir posições mais altas na estrutura política vigente, os sanitaristas no poder tiveram que negociar as propostas do movimento com os atores políticos regionais inseridos na esfera política do MPAS. A proposta final do SUDS foi portanto marcada pela contradição existente entre os interesses do movimento sanitário e os da elite política regional. Esta contradição se evidenciou quando "Uma das principais bandeiras do movimento sanitário, aparentemente consensual desde o período da ditadura - a passagem do INAMPS para o Ministério da Saúde no sentido da materialização do comando único e da unificação do campo da saúde - , começou a sofrer fortes resistências dos atores do lado do Ministério da Previdência e Assistência Social” (Pereira).

O então ministro da Previdência Social (MPAS), Raphael de Almeida Magalhães, “propunha pragmática e coorporativamente uma drástica descentralização dos recursos da previdência para Estados e Municípios, com o risco inclusive de desaparecimento do INAMPS, (mas) desde que o MPAS continuasse como 'caixa' do sistema de saúde no nível estadual” (Rodriguez Neto, 1997, p. 73). Observe que tal apoio condicionado mostrava-se politicamente significativo, no contexto de redemocratização com revalorização do federalismo no Brasil. Porquanto a decisão do Ministro do MPAS pelo SUDS se traduzia em barganha política com o PMDB, partido que havia conquistado quase todas os governos estaduais nas eleições de 1986, e cujo líder era seu amigo pessoal (Weyland).

Paradoxalmente, a transferência de recursos para estados e municípios, como proposto pelo MPAS, não resultaria na unificação do sistema sob o comando do Ministério da Saúde (Quadro 5.1), como advogado pelo movimento sanitário. Apesar disso, tal apoio condicionado permitiria dar um passo mais definitivo no processo de descentralização na saúde, também reivindicado pelos sanitaristas. Ademais, com o SUDS tanto a liderança do MPAS quanto do INAMPS pretendiam reverter o descrédito da opinião pública em relação ao setor público de 
saúde, como também demonstrar para o setor privado de serviços de saúde que "a previdência era viável, desde que dentro do Estado e desde que houvesse um rigoroso combate às fraudes” (Cordeiro, entrevista, 1992, citado em Pereira).

O contexto de democratização com revalorização do federalismo, sobretudo em sua vertente estadual, propiciou portanto a formação de um consenso político em torno da descentralização. Esta convergência redundou na elaboração de um plano que não seguiria exatamente as propostas da 8a Conferência, mas que já apresentava um caráter de mudança, no âmbito do centralismo INAMPsiano. Este consenso garantiu a decisão pelo SUDS, mesmo em meio à oposição do setor privado, representado pela FBH e ABRAMGE, e dos funcionários e caciques regionais do INAMPS.

Como ressalta Pereira, "Valendo-se da sua situação privilegiada em controlar o caixa da Previdência e da sua influência política junto ao presidente Sarney, o ministro Raphael de Almeida Magalhães obtém o apoio de Roberto Santos, novo ministro da Saúde, e de Jorge Bornhausen, ministro da Educação, no sentido de assinar a Exposição de Motivos de criação do Sistema Unificado e Descentralizado de Saúde — SUDS” (Pereira, 1996, p.15). Este foi criado por Decreto presidencial em 20 de julho de 1987 (Ministério da Saúde, 1987). Dentre as principais decisões do SUDS encontravam-se: 1) o estabelecimento de convênios com estados, e alguns municípios, transferindo recursos e responsabilidades e 2) a descentralização das ações do INAMPS (Quadro 7.1). Como assinala Cordeiro (1988), “o SUDS foi uma das poucas políticas sociais deste governo que saíram do papel” (Cordeiro, 1988, p. 38).

Quadro 7.1. Diretrizes do SUDS

\begin{tabular}{|l|l|l|}
\hline $\begin{array}{l}\text { Sobre aniversalização da } \\
\text { atenção médica }\end{array}$ & $\begin{array}{l}\text { Extinção legal da distinção existente entre assegurados e não-assegurados em relação ao atendimento } \\
\text { médico. }\end{array}$ \\
\hline $\begin{array}{l}\text { Sobre a } \\
\text { Descentralização da } \\
\text { execução dos serviços } \\
\text { de saúde: competências } \\
\text { entre as esferas de de } \\
\text { governo }\end{array}$ & $\begin{array}{l}\text { A União (MPAS) ficou encarregada das ações de caráter normativo, embora centralizasse a execução } \\
\text { de alguns serviços, como as atividades de pesquisa, cooperação técnica e de produção e distribuição de } \\
\text { medicamentos e insumos de saúde. Os estados ficaram responsáveis pela execução de serviços de } \\
\text { abrangência estatal e a coordenação intermediária de processos de planejamento e programação } \\
\text { setorial. Aos municípios caberiam tarefas de planejamento local e a execução efetiva dos serviços, } \\
\text { excetuando-se aqueles ligados a produção de medicamentos que seriam contemplados no nível } \\
\text { estadual e federal. }\end{array}$ \\
\hline $\begin{array}{l}\text { Sobre o modelo } \\
\text { médico: Gerenciamento } \\
\text { e repasse de recursos } \\
\text { pelo MPAS }\end{array}$ & $\begin{array}{l}\text { Incentivar o setor público: O INAMPS perdeu seu papel de executor dos serviços de saúde e de grande } \\
\text { comprador no privado. Está incumbência foi transferida às secretarias Estaduais de saúde e } \\
\text { municípios. } \\
\text { Incentivar práticas de controle do recurso público: O INAMPS passa a ser o órgão controlador da } \\
\text { execução global e dos repasses financeiros do SUDS. }\end{array}$ \\
\hline
\end{tabular}


O processo decisório do SUDS resultou de uma construção política na qual a proposta de reforma do movimento sanitário conciliou-se com uma proposta política mais conservadora, originária da elite oligarquia que ascendeu ao poder na Nova República. Pereira define a proposta do SUDS como uma segunda estratégia de reforma:

“(...) A segunda estratégia preconizava a modernização da máquina previdenciária com o objetivo de proporcionar maior eficiência e agilidade ao INAMPS, mantendo-o como órgão do complexo previdenciário, sem alteração de suas funções de prestador de assistência médica, como financiador das ações de saúde e controlador e avaliador dos recursos utilizados. Desta forma, o novo INAMPS, mais eficiente, forte e ágil administrativamente, continuaria a ser o locus institucional decisório das políticas de saúde. Tal estratégia tinha como defensores setores do PMDB que ocupavam espaços decisórios no Ministério da Previdência e Assistência Social — MPAS - principalmente a partir da gestão do ministro Raphael de Almeida Magalhães, em 1986, substituto de Waldir Pires, que foi disputar o governo da Bahia —, e em especial no INAMPS, por intermédio de Hésio Cordeiro, seu presidente” (Pereira, p.8).

Há que se assinalar que a participação política mais plural no processo decisório no MPAS e, sobretudo no INAMPS, permitiu dar continuidade e aprofundamento às AIS, como também antecipou-se à própria Constituição, seja no que se refere à extinção da discriminação de acesso ao atendimento médico, entre assegurados e não assegurados, seja no que tange ao estabelecimento de convênios entre os entes federativos na descentralização dos serviços de saúde. A implementação das AIS, diferentemente dos programas solidários mexicanos, apresentou uma avaliação positiva do ponto de vista da política, não impactando negativamente sobre o processo decisório do SUDS. No contexto de revalorização do federalismo - com o retorno da elite política a posições nos governos, em cargos executivos, legislativos e administrativos em todo o país - verificou-se no Brasil um nível médio de identificação ainda baixo, mas já indicativo da possibilidade de realização de lento crescimento do nível de identificação dos atores da esfera micro com a proposta de descentralização da política pública (valores e diretrizes) de saúde, tal como construída na esfera macro. A nossa hipótese é que o nível de médio de identificação da esfera política micro passou do segundo para o terceiro patamar do nível Baixo.

Apesar das críticas efetuadas por membros do movimento sanitarista, em especial, por representantes do Partido Comunista (PCdoB, 1988), figuras expressivas do movimento, como Sérgio Arouca e Paim, caracterizaram o SUDS como estratégia ponte necessária para se chegar 
ao desejado SUS (Paim, 1988) (Arouca, 1988). De forma contraditória, mas politicamente significativa, a política pública elaborada e considerada como estratégia-ponte para a concretização de um sistema universal e integral de saúde não foi a idealizada, mas apenas a politicamente possível (Paim, 1988). A decisão política de efetuar a descentralização utilizando-se da própria estrutura do INAMPS acarretaria na transferência das formas estadocêntricas de socialização relacionadas às práticas administrativas e ao modelo médico socializado no decorrer de décadas no país. Outras contradições, como veremos, virão à tona no decorrer do processo político micro do SUS.

\section{Identificação com a política macro no processo do SUDS?}

\subsection{O nível de identificação do político: baixa identificação estadual com identificação municipal}

Vejamos em que termos os governantes e executores das políticas, nas esferas políticas micro, estadual e municipal, reagiram ao processo de transferência de recursos e de responsabilidades na execução dos serviços de saúde, identificando-se com os valores do SUDS e executando suas diretrizes no decorrer do processo da política micro.

É amplamente divulgada a forma como o Governo Federal lançou mão de novos mecanismos políticos e econômicos a fim de controlar a transição política e, assim, permitiu a revalorização do federalismo na democratização brasileira (Dias \& Aguirre) (Sallum Jr,) (Saddi, 2000 e 2003). A área da saúde e, mais especificamente, o processo de transferência de responsabilidade pelo serviço de saúde da União para as unidades subnacionais tem sido bem destacado; dado o caráter precursor da saúde no processo de descentralização (Biasoto \& Oliveira, 1999) (Arretche \& Rodriguez, 1999). Esta literatura, seja no que se refere ao federalismo fiscal, seja no que tange às análises políticas do processo decisório e/ou implementação, tem procurado ressaltar os nódulos ou impasses deste processo. Estes nódulos tendem a ser explicado pela ausência da definição de regras na alocação de recursos e divisão de responsabilidades; o que explicaria o fato da alocação dos recursos e divisão da responsabilidade terem sido orientados pelo jogo político micro e inter-governamental, isto é, pela revalorização do patrimonialismo e clientelismo nas relações políticas (Medeiros) (Abrucio) (Sallum Jr.) (Saddi, 2003). 
No que se refere mais especificamente ao processo do SUDS, o tipo de comprometimento do político com a reforma de saúde mostra-se essencial para entendermos em que termos os valores e diretrizes do SUDS, como reivindicados na esfera política macro, foram internalizados e obedecidos (ou não) pela elite política e gestores de saúde na esfera política micro, orientando de fato o processo em construção. Pesquisas que procuraram apontar o grau de identificação do político ou do gestor estadual ou municipal com a reforma, como a de Silva (2001), revelam que “A presença de aliados da reforma sanitária nos municípios, como tem mostrado diversos estudos de caso, constitui fator positivo para a implementação das políticas de descentralização” (Silva, 2001, p.153). Nos casos em que se deu a cooptação de representantes do movimento ou de pessoas identificados com a sua causa para executar a nova política proposta pela esfera política macro, a proposta do SUDS foi considerada como uma diretriz estratégica do governo estadual ou municipal, sendo implementada num ritmo mais acelerado. Os aliados do movimento sanitário são geralmente caracterizados por terem tido uma gestão distintiva nas secretarias de saúde estaduais e municipais, não apenas no decorrer do SUDS, mas ao longo do processo do SUS, nos anos 90. Como ressalta Silvio Fernandes da Silva:

“Tudo indica que a municipalização da saúde depende de uma 'militância política’ para impulsionar o processo. Quando essa militância não existe ou não consegue ocupar espaços nos fóruns decisórios, o processo anda mais devagar e, muitas vezes, toma rumos diferentes dos pretendidos pelo ‘Movimento Sanitário’” (Silva, 2001, p.153).

Contudo, estes casos de alta identificação e com a participação direta de representantes do movimento sanitário no processo decisório, na esfera política micro, ocorreram mormente nos estados e municípios governados pela esquerda, o PT e PTB, e pela ala progressista do PMDB $^{122}$ (e PSDB após 1988). Nestes casos houve um comprometimento bem diversos, orem de tipo mais democrático, por parte dos Secretários e gestores, cujas atuações voltavam-se para a produção de mudanças que estivessem de acordo com a proposta do SUDS. Os relatos de

\footnotetext{
122 A Atuação do PMDB mostrava-se distinta em relação ao período autoritário. Com o processo de democratização, o partido mostrava-se mais articulado no poder, seja no nível macro, seja no micro, e, assim, apresentava uma atuação política menos crítica e mais dependente em relação aos interesses dominantes inseridos na política. O PMDB formou com o PFL a chamada Aliança Democrática que pactuou a transição da democracia. A agenda reformista aberta no inicio da Nova República foi fechada entre 87-88, devido à própria característica oligárquica ou conservadora da Aliança Democrática, formada entre as elites tradicionais do País. Esta aliança desfazia-se à medida que, num quadro de instabilidade econômica e de crise de governabilidade, se aproximava a sucessão presidencial.
} 
David Capistrano Filho e Aparecida Pimenta (1988) sobre o processo de municipalização da saúde em Bauru, assim como o relato de Jairnilson Paim (1988), em relação ao caráter mais participativo e diferencial do processo decisório do SUDS no estado da Bahia, confirmam a análise de Silva (2001). O próprio Hésio Cordeiro, na ocasião de sua saída da presidência do INAMPS, declarava que o SUDS “vai depender fundamentalmente do compromisso político dos governadores, dos Secretários Estaduais de Saúde, através do CONASS e dos Secretários Municipais de Saúde, através do CONASEMS” (Cordeiro, 1988, p.38).

Já nos estados e municípios governados por uma elite política mais conservadora, que tendia a se concentrar no PFL e na ala mais conservadora do PMDB, na ocasião, a atuação do Executivo e dos gestores, em relação ao SUDS, mostrou-se mais direcionada por práticas políticas de cunho patrimonialista, visando antes distribuir cargos políticos e recursos entre as clientelas inseridas na política micro, do que expandir a rede estatal ou municipal de saúde no intuito de possibilitar a construção do acesso aos serviços de saúde para a população. Diferentemente das gestões estaduais e municipais do PT e da ala mais progressista do PMDB, os aliados da reforma sanitária ou tiveram dificuldade em conquistar posições nas governaturas administradas pela direita conservadora, ou simplesmente nem se quer foram cooptados por elas. O processo do SUDS no estado do Maranhão mostra-se como um exemplo paradigmático da implementação da descentralização da saúde em estados nos quais dominam uma elite política patrimonialista, tendo em vista o acréscimo do número de hospitais privados pelo estado, decorrentes da distribuição discricionária de recursos efetuada pelo MPAS (Weyland), certamente, com a anuência do próprio Presidente, líder de uma das duas facções que tem alternado na administração do governo no Maranhão.

Contudo, é preciso reconhecer que apesar de ser possível distinguir o comprometimento do político como de tipo mais democrático ou autoritário, a implementação do SUDS, mesmo quando caracterizada pela militância sanitária, embora em menor proporção, também acabou sendo orientada por uma prática política tendencialmente autoritária (Shwartzman), própria da cultura política brasileira. Isto quer dizer que formas de socialização tipicamente estadocêntricas e interesses tipicamente autoritários ainda mostraram-se predominantes no processo de decisão e implementação das diretrizes do SUDS nas esferas políticas micro (estadual e municipal). Mostrava-se portanto necessário que houvesse uma substituição de valores e interesses por parte dos atores da esfera política micro, e, assim, afim de possibilitar o 
surgimento de um novo processo de internalização de valores e, consequentemente, a realização concreta crescente de mudanças na forma de socialização e de luta no processo de construção de um novo domínio público-estatal de saúde no Brasil: de natureza e escopo mais democrático.

Há que se destacar ainda que à medida que os estados se identificavam de forma contraditória com a proposta do SUDS, os municípios iam progressivamente aderindo à descentralização e à proposta de democratização do acesso com formas diversas de participação da comunidade. Com efeito, enquanto o estado, ao assumir a responsabilidade do novo sistema e do INAMPS, se revelava como o lócus de permanência de uma política pública de caráter autoritário, o município apresentava-se como alternativa política para a realização dos princípios vindos à tona na $8^{\mathrm{a}} \mathrm{CNS}$.

É este comprometimento político de intenções e natureza contraditórias, por parte dos estados e municípios, e sobretudo estados, que nos permite compreender a forma como os recursos foram aplicados na implementação do SUDS: o qual previa a estadualização da saúde. Com o SUDS, foi feita transferência das unidades de saúde, Posto de Assistência Médica (PAM) do INAMPS para estados e municípios, já que a função de executar não deveria ser mais de nível central. Os recursos foram alocados para os estados, que deveriam repassá-los para os municípios. Com efeito, a participação dos governos locais ${ }^{123}$ no total do gasto público de saúde cresceu significativamente no período, passando da faixa de 5,5\%, em 1981-84, para 45\% em 1989, tendo chegado a mais de 50\% em 1988. Este crescimento, como previsto pelo SUDS, se deu em detrimento da participação do setor privado, que caiu de 60\%, no início do período, para menos de 30\% ao seu término (Médici, 1994).

Esta descentralização de recursos para o setor público ocorreu por meio da negociação individual do MPAS/União com os estados, favorecendo, assim, a socialização de práticas patrimonialistas seja no âmbito das relações inter-governamentais, seja na própria implementação da política, no nível micro estadual sobretudo. Para representantes do movimento municipalista na saúde, como Gilson Carvalho, “A decisão do montante de recursos a ser repassado aos estados era negociada sem critérios técnicos objetivos entre o Ministério da Saúde - INAMPS e as Secretarias Estaduais de Saúde. O orientador deveria ter

\footnotetext{
${ }^{123}$ Refere-se ao repasse de recursos pelo INAMPS para estados e municípios no período das AIS, e para estados no período do SUDS.
} 
sido a Programação e Orçamentação Integradas - POI, mas como o indicador tinha limitantes e, nem sempre, era seguido a rigor, evidentemente os critérios perdiam sua objetividade, o mesmo ocorrendo com os repasses de recursos dentro dos estados entre os vários municípios”(Carvalho, 2002, p.63).

Há que se assinalar ainda que "Na maioria dos estados os recursos alocados, para cada um deles, permanecia na administração central (no estado), ainda que os estados administrassem as autorizações de internações nos contratados-conveniados e autorizassem as despesas” (Carvalho, 2002, p.65). Ademais, do montante gasto com saúde no Brasil, apenas 7,6\% em 1987 e 8,5\% em 1988 originavam dos orçamentos dos governos estatais. Observe ainda que nos anos de 1987 e 1989, respectivamente, 8,20\% e 12,30\% dos gastos com saúde no Brasil eram de origem municipal, 7,6\% e 8,5\% de origem estadual, e 84,20\% e 79,20\% de origem federal (Médici, 1994). Isto significa que o município, apesar da proposta de “estadualização da saúde” prevista pelo SUDS, já apresentava uma tendência a se mostrar mais identificado com a reforma na saúde, pois aplicava mais recursos próprios - originários do orçamento municipal - do que os estados no setor saúde. Há que se destacar ainda a ocorrência de práticas de fraude e corrupção, por partes dos estados, em especial, na aplicação dos recursos repassados pela União. Em 1988, o custo da socialização política da fraude e da corrupção na saúde foi estimado em seiscentos milhões de dólares:

"Para um repasse federal aos governos estaduais de quatro bilhões e seiscentos e noventa e dois milhões de dólares, os gastos estaduais foram de quatro bilhões e vinte e três milhões e quinhentos mil dólares. Ou seja, houve uma diferença de seis milhões de dólares dos recursos federais repassados” (Silva, 2001, p.68).

Os dados de gasto por origem entre as esferas de governo ainda demonstram a dependência das unidades federativas, tanto estatais quanto municipais, do orçamento da União. Esta ausência de autonomia financeira no processo de descentralização da nova política de saúde, adicionada ao fato da revalorização do federalismo ocorrer mediante o recurso de práticas clientelísticas na alocação de tais recursos, bem como devido à progressiva e massiva adesão de governantes e gestores de saúde dos municípios à reforma de saúde, já evidenciada na ocasião do SUDS, se mostraria como um dos principais constrangimentos na implementação do SUS na década de 90. 
Resulta, no entanto, que, nos anos 80, nem a dependência fiscal em relação à União, nem mesmo a conseqüente distribuição de recursos para clientelas políticas estaduais barraram ou impediram a implementação do SUDS. Este foi utilizado pela elite política no nível micro e em anuência com a política macro, como mecanismo de legitimação política. Do ponto de vista da política, as possibilidades de realização do SUDS, apesar de terem superaram as dificuldades ou constrangimentos evidenciados no período, ainda não produziram um alto nível de identificação com a política pública idealizado. Posicionamos a o nível médio de identificação e aceitação do político, no nível micro, num nível baixo de identificação com os valores e diretrizes produzidos inclusive por representantes do movimento sanitarista inseridos na política macro (no INAMPS).

É interessante notar ainda que o “movimento municipalista” na saúde, liderado pelos Secretários Municipais de Saúde no CONASEMS, foi crítico ao SUDS, em especial no que diz respeito ao modo como os estados executaram as políticas. De acordo com o CONASEMS, o sistema público de saúde seria mais eficaz à medida que os municípios deixassem de ser, tãosomente, executores de ações e assumissem também o papel de formuladores de políticas públicas. Note que a crítica do movimento municipalista era utilizada a fim de justificar a necessidade de estender o novo sistema de saúde ao município, e não no intuito de romper ou impedir o processo de construção da descentralização da política pública de saúde no Brasil.

\subsection{Constrangimentos administrativos: a permanência do modelo INAMPsiano}

O processo de transferência do pessoal e unidades da previdência social (INAMPS) para o controle das secretarias de saúde estaduais e municipais é geralmente dividido, sobretudo por representantes do movimento sanitário, em duas etapas. A primeira etapa compreende o período de gestão de Hésio Cordeiro (87-88) no INAMPS, quando se deu um primeiro passo no sentido de preparar a transição para o Sistema Único de Saúde (desconcentração para estados e municípios, fortalecendo o setor público; reforma do INAMPS; enfraquecimento do setor privado e privilegiamento do filantrópico). "Neste período, a Presidência do INAMPS cumpriu um papel altamente significativo na reforma administrativa do setor, introduzindo importantes elementos racionalizadores (como, por exemplo, viabilizar a superação da fragmentação institucional). Outro ponto relevante é que, ao proporcionar a descentralização das ações de saúde, atingiu a máquina previdenciária, 
modificando a correlação de forças dos agentes envolvidos na tomada de decisões e acabando por contribuir fortemente para viabilizar as alterações legais no texto constitucional, necessárias à implantação do Sistema Único de Saúde (SUS)” (Maffezoli, p.73).

No entanto, como assinalam vários autores e, entre eles, Sergio Arouca (Arouca, 1988), este processo se deu sem que houvesse uma condução única federal, uma inteligência técnica competente para administrar o sistema, que permitiria a coordenação. Tal fato agravou-se mais ainda na segunda etapa do SUDS, isto é, no final do governo Sarney (89-90), quando se deu um afrouxamento da política reformista e descentralizante do INAMPS, tendo em vista uma intensa disputa dentro da esfera política macro, entre o Ministério da Saúde e o MPAS, isto, é, entre os defensores da reforma sanitária e seus opositores (Pereira, 1996). Trata-se do mesmo período em que se dá a luta política na ANC em torno da saúde. Apesar disto, esse segundo momento não conseguiu desmontar o processo de "estadualização" ${ }^{124}$ que caracterizava a descentralização da saúde promovida pelo SUDS, também não conseguiu bloquear o movimento de municipalização da saúde, nem mesmo restaurar o antigo INAMPS para as antigas chefaturas regionais.

A não realização do comando único no sistema, e o conseqüente repasse do sistema INAMPSiano para os governos sub-nacionais, possibilitou a transferência das práticas cêntricas do sistema INAMPSiano para os estados sobretudo. A política micro herdou, portanto, o antigo sistema previdenciário para implementar uma política de acesso universal a assistência saúde. Este objetivo político foi executado por meio de uma estrutura que privilegiava a atenção curativa, bem como a perpetuação de uma política pública caracterizada pela fraude, corrupção e ausência de controle e transparência. No contexto de revalorização do federalismo brasileiro, as práticas socializadas no INAMPS se conciliariam com as práticas autoritárias da elite política, contribuindo para a reprodução de efeitos perversos na atenção médica pública no Brasil. A estrutura político-administrativa e hospitalocêntrica herdada do INAMPS foi utilizada para criar e promover as clientelas políticas locais, articuladas com a política micro estadual.

Esta permanência da cultura INAMPSiana, associada à revalorização de um federalismo estadualista e patrimonialista, encontra seu paradoxo na evasão da população e,

\footnotetext{
${ }^{124} \mathrm{O}$ termo é amplamente utilizado pela literatura, bem como pelos integrantes do movimento sanitário, para se referirem ao período do SUDS.
} 
sobretudo, da classe média do atendimento médico público. A expectativa de acesso a serviços médicos públicos começava a ser frustrada em função da má qualidade do atendimento. Como resultado, o privilegiamento do setor público como atribuído ao SUDS, propiciou uma expansão acelerada do setor médico supletivo privado. A intenção de universalização da política pública reproduziu, na prática política, um caráter de seletividade próprio do modelo americano, e bem distinto do ideário à la inglesa presente no pensamento da reforma sanitária (Vianna, 1999).

A perpetuação das práticas políticas estado-cêntricas, como a fraude, a corrupção e a conseqüente má qualidade, já estavam sendo utilizadas pelo setor médico privado e supletivo no intuito de justificar sua atuação na ANC, em oposição à radical proposta de mudança no sistema público, como preconizada pelos reformistas da Constituinte e vinda à tona na $8^{\mathrm{a}} \mathrm{CNS}$.

\subsection{Participação social e percepção do público?}

Na área da saúde, no Brasil, a população ainda não havia adquirido um status de cidadania social, na acepção marshaliana do termo, tal como ocorreu, mesmo que de forma embrionária, nos últimos anos da liberalização política e na Nova República. A implementação do SUDS possibilitou, politicamente, a continuidade do processo de institucionalização da mobilização social na saúde. Desde o período das AIS, o exercício de uma forma de cidadania social, conquistada nos movimentos comunitários de saúde, por exemplo, já começava, mesmo que de forma fragmentada e incipiente, a adquirir um formato mais politizado - e menos independente enquanto movimento contra-hegemônico -, com a inserção do movimento social na política. Tratava-se não mais de uma cidadania regulada voltada para setores específicos do mundo do trabalho, mas de uma cidadania social singular; construída num tempo de transição de regime negociado pela própria esfera política macro e em articulação com a política micro. Neste processo, a capacidade de expansão e realização da participação social já se encontrava limitada pela política e, mais especificamente, pelo tipo de comprometimento da política micro (Executivo e gestores).

Nos estados e municípios em que os aliados da reforma ocuparam posições de chefia nas Secretarias de Saúde, o processo decisório do SUDS, no nível micro estadual e municipal, foi precedido por uma ampla discussão em torno do SUDS. Esta discussão, no caso do estado da Bahia, como relata Paim (1988), deu-se com vários setores da sociedade, e em inúmeros 
espaços de debates públicos, como congressos, seminários e conferências. No caso dos municípios, o movimento pela municipalização do SUS promoveu um intenso debate em fóruns e conferências populares sobre a saúde, com destaque para a formação do CONASEMS e para a realização do V Encontro dos Secretários Municipais de Saúde em Olinda, com a produção da Carta de Olinda: demonstrando publicamente o interesse dos municípios com a reforma sanitária tal como preconizada na $8^{\mathrm{a}} \mathrm{CNS}$.

No entanto, a realização da proposta de participação social da reforma sanitária, em especial no que se refere à idealizada pelo movimento sanitário desde os anos 70 , requeria da prática política micro um rompimento total com a participação trabalhista, de cunho corporativista tal como se dava nas regionais do INAMPS ${ }^{125}$. Contudo, este rompimento com o corporativismo INAMPSiano foi parcial e diferente entre os estados. Tal rompimento mostrouse mais eficaz nos estados cuja atuação do governante e gestores caractarizavam-se mais por um comprometimento de tipo democrático do que de tipo autoritário. Aqui, encontra-se um dos desafios para a descentralização do SUDS, como reconheceu Arouca na ocasião:

“a participação social pode chegar a ser um ato de concessão benéfica, a partir da compreensão que cada governo estadual tem sobre a participação social. Então podemos chegar ao Conselho Estadual de Saúde, onde a representação estadual é feita por delegados indicados, ou chegar a estados onde a participação no governo estadual e até no distrito sanitário possa ser efetivamente o que se propunha durante a $8^{\mathrm{a}}$ CNS” (Arouca, 1988, p.54)

Estudos revelam que o SUDS “abriu as comissões interinstitucionais estaduais de saúde à participação popular e reforçou o papel de representantes da sociedade civil nas comissões municipais e locais. O programa habilitou as comissões municipais a tomar parte nas decisões sobre serviços contratados, uma vez que houvesse ocorrido a municipalização” (Cortes, 2002, p.32). Ademais, a participação dos usuários nos conselhos e conferências (também realizadas nos níveis estaduais e municipais) "tornaram os fóruns permanentes num espaço para o qual eram canalizadas demandas e conciliados os interesses, de gestores públicos e de representantes do movimento popular e sindical”(Cortes, 2002, p.36). Observe que tanto no discurso do movimento municipalista, quanto na prática política do SUDS, a questão da

\footnotetext{
125 Tratava-se de uma participação regulada pelo próprio INAMPS, e que foi minada no período autoritário. Eram os líderes do sindicato, cujos trabalhadores eram os grandes sustentadores do esquema de financiamento tripartite, que representavam os trabalhadores na mesa de negociação com o MPAS. Neste processo, os trabalhadores eram cooptados pela política.
} 
participação do usuário na saúde possui uma associação mais estreita com a vertente municipalista da descentralização da saúde. A proposta politicamente possível da reforma sanitária, como negociada no MPAS e INAMPS, que consistiu na estratégia de estadualização da descentralização da saúde, em geral não se configurava, na prática política, como uma reforma participativa.

A despeito do sucesso atribuído aos SUDS em poucos estados, como no de São Paulo $^{126}$, não houve, no entanto, o desenvolvimento de formas de participação no decorrer de sua implementação, as quais poderiam ter possibilitado a construção de uma nova forma de socialização no que se refere à prática de prestar contas de seus atores junto à sociedade. Já no caso dos municípios, vários casos de sucessos são ressaltados pela literatura. Entre eles, assinalamos o caso da cidade de Campinas (Dos Santos, 1988), que já desenvolvia um sistema de informações e registros das ações de saúde e de prestações de contas, com a realização de reuniões semanais entre os atores envolvidos na expansão da rede pública (Lavras, entrevista 2003) (Silva, entrevista 2003), desde a década de 1970.

Há que se destacar ainda que o imaginário público da sociedade brasileira em geral não apresentou uma mudança positiva em relação ao sistema público de saúde, como revela o incremento do setor privado. Esta imagem negativa em relação ao significado de público continuará sendo reproduzida nos anos vindouros, já no tempo inicial da reestruturação do modelo econômico no país, e com a adesão de grande parte da classe média à medicina supletiva ou aos seguros de saúde privados.

Apesar disso, é necessário reconhecer que os anos 80 foram marcados pelo incremento do número da pobreza no país; tendo em vista a queda acentuada do poder de compra da população, decorrente de um longo período de hiperinflação. A esta parcela da população, o SUDS possibilitou um status de cidadania que, apesar de seu caráter precário, ainda não havia sido concretizado no Brasil. Tal fato é comprovado pelo incremento do número de postos de atendimentos no país, bem como pela universalização do acesso aos serviços curativos do INAMPS. Ademais, os casos de sucessos dos municípios, bem como sua ampla articulação, indicavam que a probabilidade política de realização de uma cidadania social se mostraria maior com a extensão do processo para o município. O desafio da universalidade cedia lugar a

\footnotetext{
${ }^{126}$ Veja texto de Junqueira e Inojosa (1997): “O processo de municipalização da política de saúde em São Paulo” na Revista de Administração Pública. 31(5), p.130-51.
} 
um outro desafio, que se prolongará no decorrer da década de 90 e ainda se encontra em construção: maior equidade de acesso e garantia da integralidade na assistência médica, com o fim do INAMPS e num tempo de influência da política global neoliberal.

\section{A construção política do Sistema Único de Saúde na Assembléia Nacional Constituinte: representantes do setor privado e do movimento sanitarista.}

A realização do SUDS, que se traduziu na adesão e inserção da classe política da esfera micro na luta pela saúde, revelou-se, de um lado, em estratégia essencial de apoio no embate travado, em especial, com o setor privado de saúde em torno das definições do novo sistema de saúde na Assembléia Nacional Constituinte. De outro lado, o SUDS, ao transferir poder e recursos sobretudo para os estados, foi caracterizado pelo predomínio de práticas clientelistas, ocasionando, em alguns casos, o desvio de verba da saúde para outros fins. Estes fatos foram utilizados pela FHB e ABRAMGE, já com o apoio de políticos mais conservadores, para fundamentar a oposição ao projeto público de reforma do setor público de saúde.

Estas forças contrárias à reforma, no final de 1987, estavam politicamente representadas pelo Centrão, nome pelo qual ficou conhecido o grupo político conservador que apoiava o governo federal no Congresso, procurando garantir os cinco anos de mandato para o Presidente Sarney. O Centrão tentou interromper/dificultar a implementação do SUDS, argumentando que a descentralização havia favorecido os governos estaduais de oposição. Dentre as tentativas realizadas pelo grupo do Centrão, encontra-se a demissão de Hésio Cordeiro da presidência do INAMPS. Com esta demissão, e outras, Sarney pretendia obter apoio político do grupo do Centrão no Congresso (Cordeiro, 1988).

O Centrão também teve papel central nas polêmicas que marcaram as discussões em torno da saúde na ANC, quais sejam, 1) a definição da natureza da política pública e o papel da iniciativa privada no novo Sistema e 2) o financiamento da política pública (Rodriguez Neto, 1988). Os desfechos destes embates foram negociados entre os representantes políticos do setor privado e INAMPS, de um lado, e os representantes políticos do movimento sanitário, de outro (Arouca, 1988) (Rodriguez Neto, 1988).

A polêmica da definição da natureza pública relaciona-se estreitamente com a percepção que o setor privado de saúde tinha do risco de estatização. Em negociações realizadas a porta fechada, o setor privado advogava a possibilidade de dar continuidade à 
cobertura assistencial com recursos públicos fora do Sistema. Eleutério Rodriguez Neto contanos que “foram propostas algumas redações alternativas que contornavam o problema, explicitando a proibição de aplicação de recursos públicos para custeio, fora do Sistema Único. Por seu lado o setor privado desejava a explicitação do direito da iniciativa privada participar das ações de saúde. Ao final o acordo foi feito com esta inclusão (na constituição) (...), incluindo o 'contrato de direito público' como forma única de participação do setor privado no Sistema Único de Saúde” (Rodrigues Neto, 1997, p.85). O artigo 199, segundo o qual “a assistência à saúde é livre à iniciativa privada” foi fruto deste conflito político (Quadro 7.3).

Em meio ao embate político pela definição do conceito de público, ia-se percebendo que o movimento deveria ter apresentado seu projeto ao setor privado deste o inicio, de forma mais detalhada, a fim de não tê-lo como férreo opositor na reforma. Tal percepção encontra-se presente em várias análises, embora de forma e com matizes distintas (Silva).

Quadro 7.2 - A Saúde no orçamento da Seguridade Social: Constituição de 1988

\section{Capítulo II - DA SEGURIDADE SOCIAL \\ Seção I - Disposições Gerais}

Art.194 - A seguridade social compreende um conjunto integrado de ações de iniciativa dos Poderes Públicos e da sociedade, destinadas a assegurar os direitos relativos à saúde, à previdência e à assistência social.

Parágrafo Único - Compete ao Poder Público, nos termos da lei, organizar a seguridade social, com base nos seguintes objetivos: I - universalidade da cobertura e do atendimento; II - uniformidade e equivalência dos benefícios e serviços às populações urbanas e rurais; III - seletividade e distributividade na prestação dos benefícios e serviços; IV - irredutibilidade do valor dos benefícios; V - eqüidade na forma de participação no custeio; VI - diversidade da base de financiamento; VII caráter democrático e descentralizado da administração, mediante gestão quadripartite, com participação dos trabalhadores, dos empregadores, dos aposentados e do Governo nos órgãos colegiados.

Art.195 - A seguridade social será financiada por toda a sociedade, de forma direta e indireta, nos termos da lei, mediante recursos provenientes dos orçamentos da União, dos Estados, do Distrito Federal e dos Municípios, e de (...) contribuições sociais.

$\S 2^{\circ}$ - A proposta de orçamento da seguridade social será elaborada de forma integrada pelos órgãos responsáveis pela saúde, previdência social e assistência social, tendo em vista as metas e prioridades estabelecidas na lei de diretrizes orçamentárias, assegurada a cada área a gestão de seus recursos.

$\S 10$. - A lei definirá os critérios de transferência de recursos para o sistema único de saúde e ações de assistência social da União para os Estados, o Distrito Federal e os Municípios, e dos Estados para os Municípios, observada a respectiva contrapartida de recursos.

A polêmica da definição do domínio público na saúde relacionava-se à do financiamento, vinda à tona com a idéia de que a saúde não podia ser financiada separadamente 
das outras áreas sociais, mas teria que buscar formas para que as ações tidas como sociais pudessem ser privilegiadas no conjunto do orçamento da Nação, especialmente no nível federal. E que pra isso deveria, então, ser criada uma instância chamada Seguridade Social. Daí o porquê de não terem sido criados fundos de saúde, já na Constituição, como previsto na $8^{\mathrm{a}}$ Conferência. Em seu lugar, surgia o orçamento da Seguridade Social: destinado à Previdência, à Saúde, e à Assistência Social (Quadro 7.2). A questão não resolvida do financiamento da saúde, sob a administração do próprio Ministério da saúde, será retomada em outras etapas da reforma $^{127}$.

Quadro 7.3 - O Sistema Único de Saúde na Constituição de 1988 - resumo

Seção II - Da Saúde (no Capítulo II - DA SEGURIDADE SOCIAL)
Art.196 - A saúde é direito de todos e dever do Estado, garantido mediante políticas sociais e
econômicas que visem à redução do risco de doença e de outros agravos e ao acesso universal e
igualitário as ações e serviços para sua promoção, proteção e recuperação.
Art.197 - São de relevância pública as ações e serviços de saúde, cabendo ao Poder Público dispor,
nos termos da lei, sobre sua regulamentação, fiscalização e controle, devendo sua execução ser feita
diretamente ou através de terceiros e, também, por pessoa física ou jurídica de direito privado.
Art.198 - As ações e serviços públicos de saúde integram uma rede regionalizada e hierarquizada e
constituem um sistema único, organizado de acordo com as seguintes diretrizes:
I - descentralização, com direção única em cada esfera de governo;
II - atendimento integral, com prioridade para as atividades preventivas, sem prejuízo dos serviços
assistenciais;
III - participação da comunidade.
Art.199 - A assistência à saúde é livre à iniciativa privada.
§ $1^{\circ}$ - As instituições privadas poderão participar de forma complementar do sistema único de
saúde, segundo diretrizes deste, mediante contrato de direito público ou convênio, tendo preferência
as entidades filantrópicas e as sem fins lucrativos.
$\S 2^{\circ}$ - É vedada a destinação de recursos públicos para auxílios ou subvenções às instituições
privadas com fins lucrativos .
$\S 3^{\circ}$ - É vedada a participação direta ou indireta de empresas ou capitais estrangeiros na assistência
à saúde no País, salvo nos casos previstos em lei.

Foi como fruto deste processo de reforma de ampla mobilização social na saúde realizada nos municípios desde 1974 e na esfera macro após 1984, sobretudo - e de ocupação de posições pelo movimento sanitário na esfera política macro, que a Constituição Federal de 1988 dedicou à saúde uma seção no capítulo da Seguridade Social. O texto constitucional

${ }^{127}$ Para uma análise política mais detalhada sobre a saúde na ANC veja os textos de Rodriguez Neto e de Pereira, na bibliografia. 
configura a saúde como um direito de todos e um dever do Estado, sob a garantia de políticas econômicas e sociais dirigidas tanto para a redução do risco de doenças e outros agravos de saúde, quanto para o acesso universal e igualitário às ações e serviços de promoção, proteção e recuperação da saúde num Sistema Único de Saúde (SUS), de caráter público, descentralizado, de atenção integral e participativo (Quadro 7.3).

No novo sistema de saúde (Quadro 7.3), o acesso às ações e serviços - preventivos assistenciais e de promoção - de saúde seriam universais e igualitário. Esta expansão da cidadania social seria possibilitada por meio da construção de uma rede regionalizada e hierarquizada de ações e serviços, organizadas num sistema único e segundo três diretrizes principais: 1) descentralização, com direção única em cada esfera de governo; 2) atendimento integral, com prioridade para as atividades preventivas, sem prejuízo dos serviços assistenciais; 3) participação da comunidade.

Diferentemente da política do novo PRI no México, atores políticos contrahegemônicos, oriundos de um movimento social autônomo à política-cêntrica, haviam logrado se inserir na esfera política, conquistando posições de destaque na elaboração do novo sistema público de saúde. Neste processo, a atuação da elite política tradicional, mesmo articulada com os interesses representativos do INAMPS, do setor médico privado e, também, utilizando a descentralização do SUDS/SUS como barganha política entre governadores, não se mostrou totalmente antagônica à reforma da saúde. Os valores e diretrizes do novo SUS resultaram de um processo decisório participativo e mais plural na esfera política macro. A consolidação do marco legal do SUS mostra que políticas universais de saúde (ou das demais áreas sociais) só se institucionalizam quando movimentos sociais autônomos ou grupos de esquerda influenciam diretamente a política e, ao mesmo tempo, dá-se a produção de algum tipo de consenso político em torno da reforma a ser efetuada. Contudo, no contexto de extrema desigualdade social e regional e de desenvolvimento de uma democracia de conflito, o direito à saúde não se traduzirá plenamente em prática política no decorrer da consolidação democrática. Como veremos, não teremos no Brasil um consenso político estável e de longa duração como nas democracias sociais.

A despeito da ausência de condições políticas e sociais consideradas como prérequisitos para o desenvolvimento e consolidação de uma democracia social no Brasil, o caso brasileiro apresenta-se como um caso paradigmático de construção político-democrática da 
reforma de saúde na América Latina e, em particular, em comparação ao México. Um dos paradoxos da reforma reside no fato da política reivindicar a legitimidade de um sistema público e universal, o qual seria regulamentado e implementado não apenas numa democracia conflitiva, como também num contexto de crise fiscal profunda, resultando em novas responsabilidades financeiras para um Estado já com sérias dificuldades de reversão do quadro social gerado no período autoritário e ainda agravado pela crise econômica. O consenso político em torno da defesa dos direitos sociais se mostrará instável, e será redefinido com o surgimento de uma nova coalizão política na esfera política-macro. Na esfera política micro, por sua vez, os princípios e as diretrizes legalizados no processo decisório já estavam sendo construídos no decorrer da implementação do SUDS.

\section{A crise econômica e seus efeitos na construção do SUS}

Do ponto de vista do (neo)institucionalismo, o SUDS “foi um fracasso” (Weyland). Se este trabalho se limitasse ao federalismo fiscal ou a análise política de cunho (neo)institucionalista, já poderíamos inferir o mesmo sobre o SUDS e o vindouro SUS. Contudo, a nossa proposta é analisar a reforma brasileira como um processo de legitimação em construção, iniciado desde os anos 70: na esfera política (macro e micro) e em articulação com a esfera social. A análise do processo de decisão e implementação do SUDS, na esfera micro, nos mostrou que apesar dos paradoxos e dificuldades de realização do SUDS, houve um acréscimo, mesmo que pequeno, no nível de identificação e aceitação da política pública (valores e interesses) na esfera política micro (e suas três sub-esferas), em reciprocidade aos valores e diretrizes politicamente construídos na decisão macro. Em geral, as intenções ou motivos que levaram a esfera política micro e, em particular a estadual, a realizarem as diretrizes reivindicadas pela autoridade macro foram de ordem política autoritária. Estas intenções ainda mostraram-se antagônicas aos valores coletivos e às diretrizes mais democráticas da reforma e, por isto, limitaram, em termos de resultados práticos, o ritmo da construção da política pública reivindicada pela política macro, mediante a participação da elite política e de representantes do movimento sanitário. Contudo, neste período inicial de redemocratização, os constrangimentos derivados da prática política de cunho patrimonialista não bloquearam a continuidade e o avanço do processo iniciado pelas AIS. 
O município apresentou-se como alternativa política para a viabilização do vindouro SUS. Ademais, o processo em curso, apesar dos problemas, serviu para legitimar a luta pela institucionalização da democratização do acesso à saúde na ANC, ocasionando a inclusão do SUS na Constituição Federal. Governantes e gestores, embora apresentando comprometimentos políticos distintos com a reforma na saúde, inseriram o SUS na nova Constituição.

Nosso argumento é que diferentemente da reforma mexicana, os resultados do processo político micro do SUDS não se situaram no mesmo patamar crítico de efeitos perversos como no México, uma vez que tiveram um efeito positivo sobre a ANC, bem como não alteraram drasticamente, nem bloquearam os rumos do processo de construção da política pública, seja na esfera macro, seja nas esferas micro. Tais resultados mostram-se sim paradoxais em relação aos valores e diretrizes formuladas pelo movimento, e reivindicados como legítimos na esfera política macro, mas suas conseqüências não deslegitimaram o processo em construção. Daí o porquê de situarmos a reforma brasileira num patamar mais elevado do nível baixo de identificação com a política pública macro, em comparação com a reforma realizada no governo de De la Madrid no México.

No entanto, ao final do governo de Sarney, o fracasso da heterodoxia econômica brasileira, norteada por uma prática de precarização das finanças públicas do país, evidenciou o esgotamento do modelo desenvolvimentista. A opção pelo desenvolvimento daria lugar à alternativa neoliberal. A pergunta que propomos é a seguinte, em que termos os princípios (deslocados da sociedade) do liberalismo econômico, principalmente no que diz respeito às estratégias de enfrentamento de problemáticas referentes às políticas sociais no Brasil, passaram a orientar o processo de construção do novo SUS? Politicamente, a dificuldade de realização dos valores e estratégias do SUS não se deveu apenas à influência do neoliberalismo e à supremacia política adquirida pelo conservadorismo econômico no decorrer do processo decisório. Tal dificuldade, também se deveu ao fato da elite política brasileira, em meio às expectativas de mudança advindas na sociedade, e no intuito de se legitimar no poder, no princípio da Nova República, ter legalizado valores e diretrizes de difícil viabilização na realidade política e social brasileira. 


\section{Capítulo 8 - A construção política do SUS no princípio da reestruturação neoliberal: o período do governo Collor}

“Fora Collor!"

(grito representativo da expectativa política dos brasileiros)

Collor assumiu a Presidência da República com o apoio de uma coalizão política extremamente heterogênea, formada num contexto de polarização política em oposição à coalizão liderada pelo PT em torno da candidatura de Lula ${ }^{128}$. Com o apoio dos políticos conservadores, dos empresários e da mídia, o jovem candidato apresentava-se como um político cheio de fortuna, "veiculando um discurso que combinou em todo momento um ataque à corrupção da elite política e ao 'cartorialismo' do Estado e às idéias neoliberais de minimalização do Estado e da desregulamentação da economia como estratégia de longo prazo e de combate imediato à ameaça inflacionária” (Fiori, 1995, p.5-6). O jovem candidato comprometia-se em “defender os descamisados” e, com este discurso, reafirmava sua intenção de assegurar o direito à saúde para a população brasileira em geral. A formulação de um novo Plano Qüinqüenal de Saúde que, apesar de contrariar os princípios do SUS, não saiu do papel e, assim, traduziu-se em demonstração de mera intenção política.

Na prática política, no entanto, como tem ressaltado vários estudos sobre o processo de regulamentação da reforma de saúde no Brasil, o primeiro Presidente eleito diretamente pelo voto popular tentou bloquear as conquistas de saúde adquiridas na redemocratização, uma vez que impôs dificuldades para dar início ao processo de implementação do novo SUS, não atendendo diretamente às demandas do movimento sanitário e, mais especificamente, do movimento municipalista da saúde, como já garantido pela Constituição de 1988.

\footnotetext{
${ }^{128}$ No $1^{\text {o }}$ turno das eleições, em 15 de novembro de 1989, participaram 82,074 milhões de eleitores, o equivalente a $88 \%$ do eleitorado. Passam para o $2^{\circ}$ turno Fernando Collor, com 28,52\% dos votos, e Lula, com 16,08\%. A candidatura Lula cresce rapidamente com o apoio de candidatos derrotados no $1^{\circ}$ turno, como Mário Covas, Leonel Brizola, Roberto Freire e Ulysses Guimarães. Duas semanas antes das eleições, Collor divulga no horário eleitoral o depoimento de uma antiga namorada de Lula: ela afirma ter uma filha dele e que, na época da gravidez, teria sido pressionada para abortar. A revelação choca boa parcela do eleitorado e desestabiliza Lula. No debate eleitoral que precede as eleições, ele tem um mau desempenho. Collor vence o $2^{\circ}$ turno das eleições, em 17 de dezembro, com 35,08 milhões de votos (42,75\%) contra os 31,07 milhões (37,86\%) obtidos por Lula. Há 14,4\% de abstenções, $1,2 \%$ de votos em branco e $3,7 \%$ de votos nulos.
} 
Logo após a sua posse Collor propôs um plano de estabilização da moeda e de transformação ou modernização do Estado e da economia brasileira, com a modificação radical do padrão desenvolvimentista, vigente desde o final dos anos 30. Seu plano foi apresentado de forma abrupta e impositiva e, a partir daí, buscava apoios necessários após a tomada de decisões. A viabilização política de tal estratégia, por implicar na redistribuição de recursos na sociedade e na alteração de posições nas instituições políticas, exigiria uma demonstração de virtú por parte do então Presidente. Isto é, tal mudança requeria uma liderança política comprometida com as forças políticas e sociais integradas na esfera política, e articuladas com a sociedade. No entanto, Collor não revelou ter a vocação política necessária para liderar a democratização brasileira em tempos de neoliberalismo econômico global. O presidente eleito assumiu uma forma autocrática de governo (Sallum, 1999 e 2003), não apenas no que diz respeito à condução da política econômica, como também em relação às demais áreas da administração pública federal (Fiori, 1995) (Tavarez, 1994). Esta forma autocrática de governo de Collor é bem caracterizada por Brasilio Sallum Jr.(2003):

"Para estabilizar a moeda o Plano Collor congelou preços, confiscou provisoriamente e reduziu parte da riqueza financeira das classes médias e empresariais. Assim, além de atingir a riqueza material, ameaçou a segurança jurídica da propriedade privada. Ademais, o governo submeteu as organizações tradicionais dos empresários a ataques verbais sistemáticos, ao mesmo tempo, grupos de empresários para apoiá-lo na implementação de suas políticas. Também procurou exercer o poder dissociado da classe política e de seus mecanismos tradicionais de sobrevivência; reduziu as despesas do Estado de forma arbitrária por meio da demissão em massa de servidores, desorganizando a administração pública; e tentou enfraquecer as organizações oposicionistas de trabalhadores estimulando organizações alternativas ligadas ao governo" (Sallum Jr., 2003, p. 42).

\section{Processo decisório em tempos de liberalismo econômico e crise de governabilidade}

Ao lançar mão de uma forma autocrática de governo (Sallum Jr., 1999 e 2003), atendendo mais diretamente às demandas de contenção dos gastos e de controle das finanças públicas do novo Ministério da Economia, o novo Presidente tentou redefinir o processo de descentralização da saúde a partir de cima, ignorando os interesses das esferas políticas micro e 
social. De acordo com os economistas do governo, a reversão do quadro hiper-inflacionário dos anos 80 exigia não apenas um maior controle sobre os gastos públicos como também uma reversão da descentralização fiscal institucionalizada em 1988.

De forma contraditória, mas politicamente significativa, a continuidade da construção da legislação complementar do SUS, bem como a elaboração da primeira regulamentação do novo sistema, ambas concernentes ao direito à saúde legalmente conquistado em 1988, só se viabilizariam politicamente por meio de um processo de luta acirrada entre a esferas políticas macro e micro, e a esfera social, como próprio da democracia de conflito (Weffort, 1994), como a brasileira. A continuidade do processo de construção política da legislação do SUS foi norteada por diretrizes concernentes a duas propostas contraditórias de descentralização e de reforma da saúde: a proposta de reforma de saúde preconizada pelo neoliberalismo econômico (deslocado da sociedade e já hegemônico na política global) defendido por Collor e por sua equipe econômica; e a proposta de descentralização da saúde como garantida constitucionalmente (Quadro 7.2 e 7.3), e politicamente construída na transição brasileira.

Quadro 8.1. Diretrizes da reforma sanitária versus diretrizes do neoliberalismo econômico

Diretrizes democráticas do SUS

Descentralização como promotora d valorização do espaço público

Universalização do acesso serviços de saúde Serviço de saúde público e gratuito. Diretrizes/políticas do neoliberalismo para o setor saúde Descentralização com o fim de obter a eficiência no gasto, e como forma de promoção da prestação de contas/responsabilização fiscal.

aos Focalização: justificada pelas dificuldades fiscais dos governos para arcarem com programas sociais solidários e universalistas.

Privatização dos serviços de saúde: a defesa da privatização baseiase na busca da eficiência gerencial da gestão pública, tendo em vista a ineficiência das burocracias e empresas públicas.

\subsection{A construção política da Legislação Complementar: Executivo versus Congresso e movimento municipalista}

A legislação complementar - Lei Orgânica da Saúde (LOS 8.080) - que havia sido negociada por representantes do movimento sanitário no decorrer do ano de 1989 só foi promulgada em setembro de 1990, e sofreu vários vetos do Presidente Collor. Na LOS encontravam-se definidos os objetivos, atribuições, diretrizes, princípios, organização, financiamento e planejamento do setor saúde de acordo com as diretrizes constitucionais. Como ressaltado por Gilson Carvalho, um dos representantes do movimento municipalista na 
saúde, "Entre os muitos vetos, duas questões foram mais focadas neles: os princípios do financiamento e os do controle social” (Carvalho, p.70). E como reconhecido publicamente pelo próprio ministro da saúde Alcenir Guerra, os vetos de Collor vieram das pressões da área econômica.

O Presidente vetou o repasse de recursos fundo a fundo diretamente da União para os municípios e estados, como pactuado na Constituição, pretendendo reverter a centralização fiscal garantida em 1988. As regras e mecanismos de repasse de recursos do novo SUS passaram a ser institucionalizadas em novas portarias ministeriais editadas pelo Ministério da Saúde/Secretaria Nacional de Assistência à Saúde (SAS), as quais, dentre outras iniciativas, definiam (já desde Janeiro de 1991) que os repasse de verbas continuaria sendo feito de acordo com o critério de produção de procedimentos, efetuando-se o pagamento conforme tabela fixada, como ocorria no sistema INAMPSiano. Também foram vetados os artigos que previam a participação deliberativa da população no novo sistema público, por meio de conferências e conselhos de saúde. De forma que tanto a possibilidade de descentralização de recursos da União par a saúde, como a possibilidade de participação e maior democratização da decisão no processo da política pública foram politicamente limitadas pelos vetos presidenciais.

Outro veto importante refere-se à extinção do INAMPS. Paradoxalmente, este veto permitiu que o novo SUS fosse não apenas implementado inicialmente pelo velho INAMPS (incorporado ao Ministério da Saúde), como possibilitou que o novo sistema continuasse a sofrer as influências dos mecanismos de pagamentos e das práticas socializadas no decorrer de décadas no domínio público. Com o novo SUS, não se verificou um rompimento com as práticas INAMPSianas, como pretendia o movimento sanitário. Como assinala Carvalho, “Ao ser mantido ‘vivo’ (o INAMPS) não teve dúvidas em continuar controlando e mantendo o SUS, tomando, então, à frente na implantação do SUS”.

Em reação aos vetos de Collor, verificou-se a produção de um processo de luta articulado entre a esfera política micro e macro e a esfera social. Esta luta mostrava-se orientada pelos interesses e atuações de três atores principais: 1) pelo movimento municipalista da saúde - o qual se tornou no principal representante do movimento sanitário no período, 2) pelo Congresso Nacional e 3) pelo Presidente, que atendia de forma mais direta às demandas dos economistas do governo no Ministério da Fazenda.

Os vetos de pontos relacionados aos principais princípios do SUS deram origem a uma grande mobilização e reação de setores da sociedade civil, exigindo o cumprimento dos pontos 
acordados na discussão do texto lei. Foi “No VII Encontro Nacional de Secretários Municipais de Saúde (VII Encontro do Conasems), realizado em Fortaleza de 9 a 13 de dezembro de 1990, que o ministro da saúde Alceni Guerra reconheceu que os vetos foram decorrentes das pressões da área econômica do governo” (Silva, 2001, p.70).

Há que se ressaltar, porém, que as demandas do movimento municipalista já influenciavam a atuação dos políticos no Congresso Nacional mesmo antes do VII Encontro do CONASEMS. Como conta-nos Gilson Carvalho, a luta em torno da redefinição da LOS havia sido iniciada em setembro. Esta luta dava-se "entre Collor e os vetos e o Congresso, contra os vetos” (Carvalho, 2002, p.70). Foi exatamente após a pressão exercida pelos secretários municipais junto ao ministro da saúde que "as negociações desembocaram em se fazer uma outra lei que tratasse dessas duas questões essenciais ao SUS. Feita a negociação e com voto de liderança aprovou-se a Lei 8.142 que complementou a 8.080” (Carvalho, 2002, p.70). A Lei 8.142, juntamente com os artigos não vetados da 8.080, compreendem a Lei Orgânica da Saúde (LOS 8.080 e 8.142) do SUS.

\subsection{O princípio da fase de regulamentação do SUS}

Com a elaboração da LOS, encontrava-se finalizado o período de construção política das legislações fundamentais que iriam orientar o processo de implementação do SUS, isto é: a Constituição de 1988 e a LOS. À medida que se tentava implementar as diretrizes constitucionais da reforma na década de 90, evidenciava-se (e se evidenciará) certamente o caráter ainda geral dos valores e diretrizes da legislação do SUS. Politicamente, as problemáticas advindas da implementação exigiam (e exigirão) que o Ministério da Saúde - já em sua nova posição de regulador do sistema - apresentasse regulamentações específicas em relação aos problemas vivenciados. Iniciava-se, assim, uma nova fase no processo decisório da reforma de saúde, caracterizada como período de regulamentação ou de normatização do SUS (Levcovitz et al., 2003). Nesta, o Ministério da Saúde, com suas secretarias e o Conselho Nacional de Saúde, constituía-se como instituição política central no processo decisório da política pública de saúde.

\subsubsection{A NOB-91: controlando a transferência de recursos do novo SUS}


A nova tentativa do governo Collor em recentralizar as receitas da União se deu com a elaboração da Norma Operacional Básica da Saúde de 1991 (NOB-91), a qual apresentava uma proposta de centralização do sistema de financiamento do setor no âmbito do governo federal. A NOB-91 sofreu fortes críticas, sobretudo por parte do movimento municipalista. Possibilitou, no entanto, a regulamentação do repasse dos recursos federais para estados e municípios durante alguns anos. Uma vez que a saúde é um setor eminentemente gastador, no contexto de necessidade de arrojo fiscal mostrava-se politicamente significativo centralizar os recursos da saúde no cofre da União.

Dentre as principais críticas feitas a NOB-91, destacava-se o fato da nova regulamentação contrariar frontalmente os valores do SUS, bem como não seguir as diretrizes da LOS. De acordo com a LOS, os repasses de recursos deveriam levar em conta o perfil epidemiológico, as características da rede, isto, é, as condições que poderiam possibilitar uma maior eqüidade na distribuição de recursos, respeitando os valores do SUS. No entanto, a transferência de recursos baseada no critério de produção de serviços, como estabelecido na NOB-91, seguiu uma lógica INAMPSiana socialmente perversa. Trata-se da lógica do incremento do número de internações, da produção do número de doenças, e do conseqüente aumento de recursos (Mendes, entrevista 2003). Observe que isto é contrário a todo o novo modelo que o SUS pregava em termos de atenção à saúde. Com efeito, a NOB-91 estimulou a perpetuação do velho produtivismo médico-assistencial, em que os aumentos de exames negativos, de procedimentos desnecessários, e até atitudes fraudulentas de faturamento ocorriam juntamente com eventuais melhorias de produtividade, e ou já se encontravam embutidas nestas melhorias.

De outro lado, a NOB-91 apresentou alguns critérios claros de habilitação da gestão descentralizada para que municípios e estados pudessem receber a transferência de recursos da União. Tratava-se de critérios necessários para o cumprimento de pontos considerados fundamentais para a implantação do SUS, como a gestão municipalizada de unidades federais e estaduais, o funcionamento do Conselho de Saúde e do Fundo de Saúde, e o desenvolvimento de uma estrutura técnica de gestão, tais como sistemas de informação e vigilância epidemiológica. 


\subsection{Conferência Nacional de Saúde em tempos de crise de governabilidade}

No segundo ano de Collor, o quadro de crise de autoridade política mostrou-se evidente em vários setores da administração pública. Na Saúde, a Presidência tentou contornar o quadro de crise indicando Adib Jatene, renomado cirurgião paulista, como ministro da saúde. Paradoxalmente, a indicação de alguém da área médica para o cargo de ministro, posição aliás que só será ocupada por representantes do movimento sanitarista em 2003, possibilitou uma articulação política significativa entre a nova chefia do ministério e o movimento sanitário. Esta articulação comprova-se pela viabilização política da $9^{\mathrm{a}}$ CNS, adiada já por um período de dois anos (Bravo e Matos, 2002). A Conferência ocorreu em agosto de 1992, num período de profunda crise ética e política, em que se esperava a conclusão dos trabalhos e a divulgação do Relatório Final da Comissão Parlamentar de Inquérito (CPI) que apurava a corrupção do governo Collor.

As críticas ao encaminhamento da reforma se expressaram na IX Conferência Nacional de Saúde, onde se discutiu o processo de descentralização e, mais detidamente, a municipalização, registrando-se o impasse vivido pelo setor no processo de implementação da política traçada na Constituição e na LOS. Desse debate surgiu a idéia de construção de um processo gradativo de descentralização, mesmo que ainda submetido ao financiamento por produção, estipulado na NOB 91. A discussão sobre a configuração de uma política para a realidade institucional da saúde levou à produção do documento "Municipalização dos Serviços de Saúde - a ousadia de cumprir e fazer cumprir a lei”, apresentado no mês de discussão da Conferência.

A atuação política do movimento municipalista de saúde, legitimada por um processo de reforma em construção na política macro e micro e, de forma articulada com a sociedade desde os anos 70, possibilitou a continuidade de construção da legislação constitucional, mesmo com os vetos de Collor. Não sendo possível reverter a legislação constitucional, o Executivo passou, juntamente com o Ministério da Fazenda, a influenciar de forma determinante a elaboração da primeira norma técnica do Ministério da Saúde sobre o SUS. De forma contraditória, os argumentos de eficiência foram utilizados para manter o mecanismo de pagamento por procedimentos, utilizado na socialização das práticas de desperdício, de produção de doenças, de internações, de fraudes e, portanto, de alto custo e ineficiência no sistema. A reação do movimento sanitário à forma como Collor conduziu a política de saúde, 
juntamente com os municipalistas da saúde, concretizou-se na Conferência. Nesta, as vozes dos sanitaristas, secretários e administradores e acadêmicos do setor de saúde juntaram-se a de milhares de brasileiros e dos chamados cara-pintadas, em manifestação nas grandes cidades: Fora Collor!

Ao compararmos o processo de reforma brasileiro com o mexicano, é importante ressaltar que mesmo no período de Collor, quando a maior parte dos representantes do movimento sanitário se encontrava nas secretarias estaduais ou municipais, o processo decisório do SUS apresentou-se como um processo mais participativo. A despeito das atitudes autocráticas do governo Collor, a participação política mais plural no processo decisório, bem como a influência mais positiva exercida pelo processo de implementação da reforma brasileira sobre o processo de decisão, demonstram que o SUS apresenta-se como um processo certamente ainda genético e em construção, mas com legitimidade política. Foi este padrão mais amplo de participação e politicamente mais conflitivo de construção da reforma que garantiu a continuidade de construção do SUS no momento da transição para o neoliberalismo econômico.

\section{Processo político do SUS na esfera micro}

Vejamos então em que termos as diretrizes reivindicadas pela autoridade legislativa, na Constituição e na LOS, e pela autoridade sanitária e Executivo (com a NOB-91), já estavam sendo de fato realizadas e reconhecidas como legítimas no decorrer do processo de decisão e implementação do SUS, na esfera micro, no período do governo Collor.

\subsection{Identificação do político}

Com a NOB-91 os estados perdem sua função articuladora e, com isto, a descentralização do SUS, como já ocorria desde meados do governo Sarney, continuou avançando por meio da radicalização do vetor municipalização. Isto ocorreu porque a lógica da transferência de recursos favorecia a relação direta entre o nível federal e os municípios, com pouco poder de intervenção do nível estadual na definição dos critérios utilizados. Com isto, os estados perdem a função articuladora e negociadora observada no período SUDS (Levcovitz, 1997). 
A adoção de critérios de repasse de recursos por remuneração de produção feria a autonomia gestora das unidades sub-nacionais, uma vez que a transferência de recursos se daria diretamente para as unidades ambulatoriais e hospitalares. Isto criava alguns limites para o avanço do processo de descentralização: impedia que os recursos fossem re-alocados diretamente pelos estados e municípios, limitava a atuação do gestor local no que diz respeito à capacidade de direcionamento do modelo assistencial, bem como restringia o uso e aplicação e adequação dos recursos transferidos (Levcovitz et al., 2001) (Carvalho, 2001) (Cordeiro, 2001).

A partir de 1990 passou a ocorrer a redução do repasse de recursos federais para as unidades sub-nacionais, o que fez com que os municípios passassem a utilizar cada vez mais parte do seu próprio orçamento fiscal com saúde. No caso de Marília, os recursos federais cobriam 70\% do orçamento entre 1987 e 1989, sendo que em 1990 este montante chegou a $20 \%$ apenas. Silva conta-nos que "o prefeito sentiu-se enganado porque sua expectativa, quando municipalizou, era de que fossem mantidos os mesmos aportes de recursos” (Silva, 2001, p.162). Apesar da problemática de financiamento, houve continuidade e aprofundamento da adesão dos prefeitos e secretários municipais de saúde ao SUS no inicio da década.

Para o político local, sobretudo municipal, a possibilidade política de desenvolvimento de um novo sistema público de saúde sobrepôs-se às constrições e limites políticos impostos pelo Executivo Federal. De acordo com Levcovitz e outros (2001) “muitos municípios aderiram a esta norma e à sua substituta (a NOB SUS 01/92), tendo assinado o convênio 1.074 municípios, até o final de 1993. Levcovitz (1997) compreende “a aceitação e adesão dos secretários municipais de saúde aos convênios como expressão da sua insatisfação com o relacionamento privilegiado entre as Secretarias Estaduais de Saúde e o INAMPS no período SUDS e como forma de responder aos anseios urgentes de descentralização” (Levcovitz et al., 2001, p. 274). Ressaltamos que o fato de mais de mil municípios terem se habilitado à nova NOB, num contexto ainda inflacionário e de arrojo fiscal, demonstra que o político municipal sobretudo identificava-se positivamente com a proposta de reforma.

Há que se destacar ainda que esta adesão dos municípios à NOB-91 foi lenta e os incentivos financeiros transferidos pela União mostraram-se inconstantes, no âmbito da crise fiscal do Estado. Ademais, pesquisa realizada em alguns municípios brasileiros pelo Instituto de Saúde de São Paulo (Heimann et al., 2000) revela que “a maioria dos municípios estudados não criou mecanismos adicionais de financiamento para a saúde. As iniciativas citadas pelos 
gestores e representantes da comunidade ... quase se restringiram às fontes tradicionais do Ministério da Saúde” (Heimann et al, 2000, p.72).

Esta crise de financiamento impactará politicamente o processo de construção do SUS no decorrer de toda a década, e terá efeitos negativos sobre a condução da administração pública na gestão e oferta de serviços de saúde, bem como sobre a percepção dos usuários e prestadores sobre o novo sistema público em construção, como veremos.

\subsection{Identificação da administração pública: qualidade precária e princípio da mudança no modelo médico}

É preciso lembrar que a NOB-91 possibilitou o incremento e desenvolvimento de uma capacidade institucional e técnica para a gestão da saúde inédita na inédita na História e na cultura municipal do país. Para muitos municípios, "os convênios deram origem a uma primeira aproximação concreta com as questões técnico-operacionais do SUS. Provavelmente, a ampliação do envolvimento municipal na construção do novo sistema de saúde tenha sido o principal avanço proporcionado pelas portarias do MS e pelas NOB SUS 01/91 e NOB SUS 01/92” (Levcovitz et al., 2001, p. 275). É preciso lembrar ainda que isto ocorreu num contexto em que “os secretários estaduais de saúde não foram capazes, técnica e politicamente, de promover uma articulação apropriada para propor outro modelo de relacionamento e financiamento" (Levcovitz et al., 2001, p. 275). Sob distintas condições financeiras e administrativas e sob influências diversas da política local e do grupo de sanitaristas locais (envolvidos na política) os municípios continuavam a assumir gradativamente a implementação do SUS.

No contexto de crise de financiamento, a permanência da modalidade de financiamento INAMPSiana, como já ressaltamos, deu sobrevida, no novo sistema, à velhas práticas perversas da assistência pública médica brasileira. Em Marília, “A lógica do financiamento forçava a produção de atos curativos. Os serviços tinham que faturar, atendendo à doença, reforçando, com isto, o modelo clínico-curativo tradicional” (Silva, p.162). O caso de Marília pode ser generalizado para todo o país. De acordo com Barjas Negri (2002), “A fragilidade dos mecanismos de controle herdados do antigo INAMPS era conhecida. Isto gerava fatos histriônicos, como o caso de apresentação de faturas referentes a partos realizados em homens” (Negri, 2002 p.24). Ademais, a universalidade da atenção pública "levou a um quadro generalizado de redução na qualidade da assistência e no sucateamento da infra-estrutura. E 
então se pode verificar que o início dos anos 1990 tinha como uma de suas marcas a degradação dos serviços públicos de saúde” (Negri, 2002, p.24).

De outro lado, no entanto, mais além das práticas médicas hospitalares INAMPSianas, foram originadas e desenvolvidas, em alguns municípios, experiências de sucessos de atenção básica à saúde, reconhecidas nacionalmente e internacionalmente. Há que se ressaltar a iniciativa no município de Niterói, precursor na implementação da atenção básica familiar no país, tal como ocorreria nos anos vindouros, com o PAC e o PSF. A experiência de Niterói originou-se em 1992 e foi influenciada pelo modelo médico de família de Cuba (Teixeira, et al., 1999). Observe que as iniciativas de atenção primária de saúde (APS) ${ }^{129}$ no Brasil surgem “de baixo”, ocorrem antes como experimento idealizado por um grupo de sanitaristas e, posteriormente, tendo em vista a credibilidade e legitimidade adquirida, há ou uma articulação com os representantes do movimento sanitário e um esforço por parte do próprio governo federal (juntamente com técnicos e economistas do governo) para inserir estes programas nas vindouras regulamentações do SUS.

\subsection{Identificação social}

Há que se ressaltar ainda que a NOB-91 também permitiu o surgimento de novos atores sociais nas instituições públicas de saúde, os quais passariam a ter um peso crescente, porém diversos, no processo decisório da saúde, como os Secretários Municipais e diversos grupos de usuários, através dos Conselhos Municipais de Saúde. Em Marília, o Conselho Municipal (CMS) foi regulamentado em 1990, logo após a LOS. A pesquisa de Silva demonstra que entre 1991 e 1992, o governo local, dentre os demais representantes do CMS, usava o Conselho para transmitir informações e incluir temas gerenciais e de qualidade da assistência na agenda política. Dentre os temas e decisões efetuadas, 30\% permaneciam na agenda do CMS, e 70\% eram priorizados pelo Executivo municipal. De acordo com o autor, os itens priorizados "são

\footnotetext{
${ }^{129}$ De acordo com a Organização Mundial de saúde a APS, como definida na Conferência de Alma Ata (1978) pode ser conceituada como atenção de saúde essencial, baseada em métodos e tecnologia prática, científica e socialmente aceitável. É de acesso universal para indivíduos e famílias na comunidade. APS é a função e o foco central do sistema de saúde do país e do desenvolvimento social e econômico da comunidade. É o primeiro contato do indivíduo, da família e da comunidade com o sistema nacional de saúde, aproximando-se o máximo possível do local onde vivem e trabalham, constituindo o primeiro elemento de continuidade do processo de atenção à saúde. Os países implementaram programas de APS em seus sistemas de saúde com muita diversidade, embora destacassem caminhos particulares para propósitos comuns.
} 
encaminhados para implementação imediata ou, se isso, não for possível, para alguma resposta mais efetiva” (Silva, p.170). As reclamações mais significativas feitas no CMS, entre 1991 e 1992, foram a reclamações sobre qualidade da assistência $(28,6 \%)$ e sobre remuneração dos serviços pelos prestadores $(31,4 \%)$.

\section{Paradoxos de uma política em construção: legitimidade e política de saúde nos governos de Collor e de Salinas}

Observe que, diferentemente do período de Salinas, o processo da reforma brasileira não foi interrompido com Collor, nem mesmo houve uma alta rejeição à NOB-91 formulada pela política macro. Daí o porquê de não ser possível apontar que a política micro, no decorrer do processo do SUS, logo após o período constitucional, apresentou um nível extremamente baixo ou nulo de identificação com a política pública decidida na esfera macro (como no México). Entendemos que o nível de identificação do político local tendeu a oscilar entre o Baixo4 e Médio, variando conforme o município. Supomos que, numa média geral, o nível de identificação da política micro se posicionou no primeiro patamar do nível médio, tendo em vista as dificuldades de realização de um novo modelo de atenção, num contexto de crise fiscal e de sobrevivência de velhas práticas políticas na instituição pública.

Em comparação com o período de Salinas, no México, os paradoxos das conseqüências ou problemáticas vindas à tona no decorrer da implementação do SUS, no período de Collor, mostram-se menos perversas, tendo em vista a existência de uma certa continuidade no processo de descentralização da política pública, em relação ao SUDS, bem como o maior grau de aceitação da proposta da reforma no decorrer da implementação. Ressaltamos que o processo do SUS no período de Collor, apesar da crise de autoridade sofrida pela política macro, apresentou um maior nível de legitimidade em relação à reforma solidária de Carlos Salinas.

Em termos comparativos, é preciso reconhecer que o grande paradoxo do SUS nos anos de Collor deveu-se ao fato da crise de credibilidade da política macro não ter se traduzido, pelo menos não mesmo grau, em crise de credibilidade da política pública de saúde. O SUS correspondeu a um projeto construído de forma mais participativa na esfera política macro, e como maior nível de reciprocidade em relação à esfera micro. Vejamos em que termos se deu a construção política de nova regulamentação e decisões no governo de Itamar Franco. 


\section{Capitulo 9 - Construindo o SUS em tempos de incerteza política e de instabilidade econômica: o governo de Itamar Franco (de 02/10/1992 a 01/01/1995)}

Em meados de 1992, o padrão autocrático de governo de Collor não logrou produzir a coesão política necessária para alterar o padrão de desenvolvimento, logo, de redistribuição dos recursos econômicos no País. Ao contribuir para o acirramento da crise de governabilidade na nova democracia política brasileira, o fracasso do experimento autoritário da ortodoxia econômica ${ }^{130}$, com o Plano Collor, trazia um ensinamento sócio-politicamente significativo: a estabilização econômica não se daria “a partir de cima” tão-somente, ou melhor, por meio do exercício autoritário do poder, como ocorreu no México, por exemplo. Desde o período de transição de regime político, bem como ao longo do início da redemocratização política, o retorno da forma de governo democrática no País tem sido caracterizada pela pactuação com atores hegemônicos inseridos na política - como a elite oligárquica e militares - ou articulados no poder - empresários e setores sociais organizados. Tendo em vista o caráter instável das novas democracias, como a brasileira, a simultaneidade de dois processos de mudança (regime político/consolidação e reestruturação econômica) contribui enormemente para que os novos regimes se apresentem como uma "democracia de conflito" (Weffort, 1994): fato que reduz a viabilidade política de um governo autocrático. Observe que foram os próprios grupos políticos e mídia, antes em aliança com o então candidato/Presidente Collor, que se tornaram autônomos em relação ao Executivo Federal, efetuando uma articulação política em torno de seu impeachment. Este processo de ética na política também era uma expressão das próprias forças sociais que, apesar de terem realizado amplas e diversas mobilizações sociais e/ou políticas no decorrer da dupla transição política brasileira, haviam sido ignoradas pelo primeiro Presidente eleito.

De forma que Itamar Franco assumiu o poder num contexto de alta instabilidade política e baixa credibilidade das políticas econômicas. Do ponto de vista do processo decisório da política pública de saúde, o novo governo pode ser dividido em dois períodos políticos distintos, relacionados à forma como se deu a articulação entre os processos de democratização

${ }^{130}$ Desde o principio de 1993 verificou-se um acentuado incremento da taxa de inflação, que atingiu níveis superiores ao pico inflacionário do período da Nova República, chegando a 2.579\% ao ano. 
e de estabilização econômica. Nosso argumento é que a crise de governabilidade, caracterizada pelo acirramento da incerteza política e instabilidade econômica, produziu tempos de oportunidades políticas tanto para as forças político-sociais organizadas quanto para políticos e setores econômicos influírem sobre o processo da política macro.

Trata-se de tempos em que se evidenciaram oportunidades políticas distintas para a atuação do movimento sanitarista e municipalista de saúde na construção das regulamentações e novas estratégias do SUS, de um lado, e para atuação e influência dos economistas do governo e políticos em aliança com o Ministério da Fazenda na elaboração e implementação do Plano Real, de outro. Este plano, ao apresentar-se e revelar-se como instrumento de coesão político-social e, portanto, de legitimidade da política macro, inaugurou de forma mais definitiva e prolongada, uma nova fase da reforma pública de saúde brasileira. Esta nova fase mostrou-se determinada em seu princípio e desenvolvimento (após 1994) por um processo político mais amplo: pela alteração produzida no padrão de relação existente entre Estado e sociedade, ou melhor, entre esfera políticas macro e micro e esferas econômica e social na construção do SUS.

\section{O processo decisório em tempos de crise de governabilidade}

O primeiro tempo político característico do processo decisório do SUS, no governo de Itamar Franco, compreende o final de 1992 e ano de 1993, quando as pressões de cunho mais democráticos, advindas da esfera social e da esfera política micro sobre a decisão da política macro tornaram-se mais autônomas e politicamente significativos em relação ao período Collor. Já o segundo tempo refere-se ao período de divulgação e início da implementação do novo plano de estabilização econômica (articulado politicamente pelo próprio ministro da Fazenda no decorrer de 1993), em que as pressões sociais e da política micro - sobre a política macro - tornaram-se menos autônomas e mais subordinadas à nova política econômica do governo. Enquanto em 1993 houve uma participação e influência mais acentuada do movimento sanitarista na elaboração da nova Norma, em 1994 esta participação passou a mostrar-se limitada, como ocorreria no decorrer de toda a década, tendo em vista a atuação política mais autônoma e legítima adquirida pelo Ministério da Fazenda e seus representantes. 


\subsection{A NOB-93 e a participação dos municipalistas}

Em meio à instabilidade política legada pela dupla transição política brasileira, e acirrada com o governo Collor, o novo Presidente procurou restaurar o compromisso com a implementação do SUS, por meio da elaboração da Norma Operacional de 1993, conhecida como NOB-93. Gilson Carvalho conta-nos quais foram as primeiras iniciativas do governo Itamar em relação ao SUS, bem como se deu a participação dos municipalistas no período:

"Politicamente estava ocorrendo o processo do impeachment do presidente Collor. A IX Conferência Nacional de Saúde repercutiu a indignação nacional, bradando: Fora Collor! Com a renúncia de Collor, assumiu Itamar que entregou a Jamil Haddad o Ministério da Saúde. Os ditos 'municipalistas do CONASEMS' foram convidados a ajudar na nova administração do Ministério da Saúde. Mosconi assumiu a SAS e a presidência do INAMPS. Foi constituído pelo ministro o Grupo Especial de Descentralização (GED) que começou, colegiadamente, a discutir uma proposta de descentralização cuja expressão maior era a própria temática da IX Conferência: ‘Municipalização é o Caminho’” (Carvalho, 2001, p.439).

Foi com base nos pressupostos reiterados no documento 'Municipalização das ações e serviços de saúde: a ousadia de cumprir e fazer cumprir as leis’, produzido pelo GED, que se deu a elaboração da nova NOB-93. Dentre os pressupostos ressaltados pelo GED destacavamse os seguintes pontos: 1) redefinição das responsabilidades entre as três esferas de governo, reorganização institucional, reformulação de práticas das três esferas de governo com estabelecimento de novas relações entre elas; 2) o desenvolvimento de um processo de negociação e pactuação; 3) implantação imediata do controle social; 4) o reconhecimento de que o processo não comporta rupturas entre as velhas e as novas práticas e, por isto, necessita de transição.

A nova NOB-93 responde politicamente às demandas e diagnósticos dos municipalistas para o avanço e implementação do novo sistema. Dentre as respostas da NOB merecem destaque 1) a implementação de estádios de habilitação ou de adesão ao SUS e 2) a instituição das comissões intergestoras como instrumentos de negociação no SUS.

A NOB-93 determinava que a autonomia de gestão do município ou estado no processo de descentralização se daria de forma gradual. Os governos deveriam integrar-se ao SUS em um dos três estádios distintos de habilitação da gestão: a gestão incipiente, a parcial e a 
semiplena A autonomia de gestão seria adquirida à medida que cada governo sub-nacional avançasse de um estádio de habilitação de gestão para outro. A habilitação do município ou estado a um dos estádios deveria levar em conta a capacidade da política micro assumir responsabilidades administrativas e financeiras na gestão do sistema de saúde em suas regiões ou localidade. O repasse de recursos financeiros para os municípios habilitados seria determinado de acordo com sua categoria de habilitação.

A fim de possibilitar um processo de negociação mais efetivo entre estados, municípios e União no decorrer da construção política do SUS, a NOB-93 constituiu as Comissões Intergestores Bipartites (CIB), nos estados, e as Comissões Intergestores Tripartite (CIT), na esfera federal. As comissões foram criadas com o objetivo de promover o debate entre os gestores do sistema de saúde dos três níveis de governo (federal, estadual e municipal), os quais deveriam contribuir para a formulação de propostas para a implementação do SUS.

A nova NOB-93 legalizava um processo que, mesmo de forma variada e ainda sem a adesão completa de todos os municípios, bem como em meio a recusa geral dos estados em arcar com a responsabilidade pelos serviços de saúde, não se mostrava como uma intenção de nova fortuna política, que visava tão somente recuperar um quadro de crise de governabilidade crítica vivida pela política macro. Propunha-se, a partir da esfera macro e em articulação com a esfera política micro e a social, uma proposta que já vinha sendo realizado na prática política pela esfera política micro (municipal sobretudo).

\subsection{Crise de governabilidade e corrupção: a extinção do INAMPS}

Outra decisão importante produzida em meio ao contexto de alta instabilidade política do governo Itamar Franco refere-se à extinção do antigo INAMPS. Tal medida havia sido vetada por Collor devido às pressões anti-descentralização decorrentes da burocracia da SAS (INAMPS), do próprio Ministério da Saúde e de várias esferas da administração pública federal como um todo, bem como dos prestadores de serviços de saúde, que tinham medo das dificuldades financeiras e/ou do maior controle que pudesse resultar da descentralização (Carvalho, entrevista 2003). É importante afirmar, como ressalta Eduardo Jorge Sobrinho (2002), que em Brasília nenhum político acreditava na descentralização do SUS, em especial no que se refere à sua vertente municipalista. 
A sobrevida outorgada ao INAPMS, após 88, limitou a própria autonomia e autoridade política do Ministério da Saúde no que se refere à possibilidade de construção de uma atenção médica pública diferenciada da atenção hospilocêntrica INAMPSiana. Porquanto a SAS, isto é, a secretaria criada para a incorporação do antigo INAMPS transformou-se no órgão mais forte de todo o Ministério, dando um novo caráter de dualidade no processo decisório da saúde. Era na SAS que se dava de forma mais acentuada a continuidade das práticas institucionalizadas no velho sistema. Isto quer dizer que o INAMPS (SAS) continuou sendo o lócus de inserção de parte do setor privado e da indústria de saúde articulados com servidores públicos na reprodução da corrupção e fraude. Daí o porquê do acirramento dos conflitos e acusações de corrupção na saúde se concentrarem na SAS (Elias, entrevista 2003) e, assim, estarem relacionadas mais estreitamente com a atenção médica pública (ou conveniada ao público) hospitalar secundária e de alta complexidade.

No período do governo Itamar Franco as pressões pela sobrevivência do INAMPS (na SAS) continuavam acirradas, no entanto elas eram realizadas num contexto de crise de governabilidade e numa fase mais avançada da reforma da saúde, em que o SUS, a despeito dos inúmeros problemas, mostrava-se como uma política pública com legitimidade política. Tratava-se também de período mais avançado de democratização em que a publicidade da ética na política mostrava-se politicamente significativa para o exercício do poder.

Entrevistas realizadas nos permitem apontar que a extinção do INAMPS foi articulada pelo próprio Carlos Mosconi, no entanto, outros protagonistas mostraram-se essenciais para a conclusão do processo em sua rota final. O então presidente do INAMPS (SAS) era amigo pessoal e aliado político do Presidente Itamar Franco em Minas Gerais. Como Deputado Federal, o médico Carlos Mosconi foi um dos principais representantes políticos do movimento sanitarista no decorrer da luta pelo SUS na Assembléia Nacional Constituinte, bem como já havia tido experiências na administração pública de saúde e docência na Faculdade de Medicina da UFMG em Minas Gerais. Mosconi conta-nos que em sua posse deixou claro a intenção de extinguir com o INAMPS, o que implicaria numa revisão do papel da SAS no Ministério da Saúde e no SUS: “Assumi o INAMPS e disse na posse que o meu interesse era acabar com a instituição” (Mosconi, entrevista 2003).

O próprio Carlos Mosconi relatou-nos, em entrevista, que sofreu vários tipos de chantagem e ameaças de morte no decorrer do processo. Lembremos, como vimos no primeiro 
capítulo, que o rompimento com o INAMPS feria diretamente interesses políticos cristalizados no domínio público, porém socializados de forma perversa como domínio privado no decorrer de décadas no País. De acordo com Mosconi, na ocasião o INAMPS ainda tinha 130 mil funcionários e era, com os pagamentos do "cheque em branco" das AIHs na SAS, o terceiro maior orçamento da União. No entanto os prédios do INAMPS, localizados nas capitais, já se mostravam com capacidade ociosa com o SUS (Mosconi, entrevista 2003).

Segundo o Jornal o Estado de São Paulo, "De acordo com as estimativas oficiais, entre Cr\$ 3 trilhões e Cr\$ 4 trilhões - 30\% a 40\% do total de recursos movimentados pelo Inamps são desviados por mês pelas fraudes no sistema de saúde. As irregularidades são antigas, e as denúncias feitas pela imprensa no último final de semana eram de conhecimento do governo desde 11 de março quando foram abertas as auditorias especiais para investigar os médicos e hospitais, que por receberem repasses elevadíssimos, estão sob suspeição. Eles foram identificados graças à informatização do Inamps” (Evelin, 1993).

Com a auditoria em curso no INAMPS, e em meios às denúncias de promotores e publicidade da mídia sobre a corrupção instaurada na Central de Medicamentos (CEME), e mesmo tendo em conta a pressão política perversa exercida sobre o então presidente do INAMPS (SAS), o Presidente Itamar Franco formou uma Comissão que deveria apresentar um relatório propondo uma solução para o problema. Paulo Elias ${ }^{131}$, um dos três coordenadores desta Comissão, conta-nos resumidamente como se deu este processo de seis meses que garantiria a extinção do INAMPS:

"Foi no período Itamar que começaram as denúncias de corrupção na Central de Medicamentos (CEME) do INAMPS. A CEME tinha uma quantidade imensa de recursos e eles licitavam milhões para a compra da indústria farmacêutica. O Itamar chamou a Luiza Erundina de Souza, então ministra, e falou para ela que queria acabar com a CEME e com o INAMPS. A Luiza Erundina de Sousa falou o seguinte: Eu comando, mas eu quero envolver o Jamil. Então ela criou uma Comissão Tri-partite de representantes da Secretaria de Administração, três representantes do Ministério da Saúde indicados pelos Jamil. Eu fui um dos três que coordenou o processo. A extinção do INAPMS foi um processo que durou 6 meses e no momento final isto apareceu na imprensa.

\footnotetext{
131 Paula Elias é professor do Departamento de Medicina Preventiva da Faculdade de Medicina da USP e pesquisador do CEDEC. Havia trabalhado por 2 anos como assessor do Eduardo Jorge no $1^{\circ}$ mandato da Luiza Erundina, em que negociava todos os projetos de saúde na Câmara de Vereadores em São Paulo.
} 
Na véspera da reunião que extinguiria o INAMPS, saiu uma matéria na Veja dizendo que a extinção do INAMPS iria fomentar a corrupção na área de saúde e que, como conseqüência, o governo não teria mais controle, pois iria acabar com o sistema de auditoria e aí lembravam toda a história de fraude e corrupção do INAMPS. Também ficamos sabendo no fim de semana que o Ministro da Saúde, Jamil Haddad, havia sofrido pressões e pretendia recuar em relação à extinção do INAMPS. Ele confessou para a Luiza, por telefone, que já estava articulando um novo relatório para a Comissão formada. A Luiza passou o maior sermão no Jamil e continuou firme na luta. Na segunda-feira a Comissão levou o projeto de lei para o Itamar no Palácio. Tivemos uma reunião de duas horas e meia com o Itamar. Eu tinha aquela idéia que o Itamar era indeciso. Bom, nesse dia, não teve indecisão nenhuma. Foi assim que acabou o INAMPS, Luisa Erundina de Souza e Itamar Franco tiveram um papel preponderante na extinção do INAMPS” (Elias, entrevista 2003).

Com a extinção do INAMPS criava-se a possibilidade política de efetuação de reformas na SAS. No entanto, como evidenciam os atuais escândalos de corrupção e fraude na SAS no governo Lula, esta reforma só começará a ser efetuada, de forma mais definitiva, no período do governo Lula, quando os representantes do movimento sanitarista ocuparão pela primeira vez a liderança do Ministério da Saúde, bem como a chefia de suas secretarias ${ }^{132}$. O sistema de pagamento por procedimentos, atrelados a uma tabela de preços praticamente inalterados, continuará vigente no decorrer da década de 90, e será mantido juntamente com o repasse Fundo a Fundo, como veremos na próxima sessão.

Há que se reconhecer a atuação política virtuosa do Presidente da República, dos membros da Comissão Tri-partite formada e do então Presidente do INAMPS na construção do instrumento de legalidade que garantiu a extinção político-institucional do INAMPS. A virtú política destes atores deve-se ao fato de suas atuações ocorrerem em meio a pressões políticas e corporativas, articuladas com a indústria de saúde e com parcelas do setor privado (ainda ligadas ao SUS), e reveladas na matéria publicada pela revista com maior repercussão política no cenário nacional. Como amplamente denunciado pelo movimento sanitarista, e claramente visível no caráter de continuidade da atuação elitista do Ministério da Saúde, mesmo em época de SUS, a mídia brasileira tem promovido a publicidade da opinião de grupos políticos e

\footnotetext{
${ }^{132}$ A reestruturação da SAS, com destaque para o inventário (investigação policial) de corrupção na compra de medicamentos e insumos médico hospitalares, realizado a pedido do próprio ministro Humberto Costa e sua equipe -, mostra-se como uma das principais reivindicações de mudança que a comunidade de saúde coletiva espera de seus representantes na atual chefia do Ministério da Saúde.
} 
sobretudo econômicos dominantes (Kuscinky, 2002). Apenas nos períodos de acentuada mudança no processo do SUS, como na Constituição, o quarto poder mostrou-se como lócus de publicização mais imparcial e decisivamente informativo sobre o processo de construção do SUS no País.

\subsection{Instabilidade econômica e crise de financiamento na Saúde}

A vitória conquistada com a extinção do INAMPS deu-se paralelamente a uma decisão política arbitrária que contribuiu de forma acirrada para limitar, do ponto de vista financeiro, a construção do SUS. Em meio à crise fiscal do Estado e, a conseqüente dificuldade de arcar com o pagamento dos $147 \%$ devidos aos aposentados e não pagãos pelo governo Collor, o ministro da Previdência Antônio Britto apropriou-se dos recursos provenientes da folha de pagamento dos trabalhadores, os quais deveriam ser repassados pela Previdência para o MS, como consta no Orçamento da Seguridade Social. Em reação a este confisco no orçamento da Saúde, o Deputado Eduardo Jorge, representante dos sanitaristas no Congresso Nacional, propôs um projeto de lei que visava vincular percentuais dos orçamentos municipais e estaduais e da União para o setor Saúde, com vista à expansão da alocação para a saúde de recursos fiscais (de estados e municípios) de forma compulsória. Tal projeto, que resultou na Emenda Constitucional 29/2000, só foi aprovado em $2000^{133}$.

Como Parlamentar, Britto foi o relator oficial da Comissão da Reforma da Previdência. Dentre as conclusões da comissão encontravam-se as seguintes sugestões: 1) que a contribuição sobre salários fosse utilizada, exclusivamente, para pagamento de pensões e aposentadoria e 2) que o repasse para a saúde deveria se limitar à forma Fundo a Fundo, como consta na Lei 8080. Ao assumir o cargo de ministro, Britto procurou seguir de alguma forma a primeira sugestão do relatório. Como ressaltam vários especialistas de saúde pública e representantes do movimento sanitarista, a apropriação dos recursos da saúde do OSS deu-se de forma repentinamente. "O Ministro Britto, sem nenhum documento oficial, apenas por declarações de gabinete, suspende o repasse à saúde no mês de maio de 1993” (Carvalho, 2002, p.76).

\footnotetext{
133 Após a EC-2000 a Saúde passou, de forma mais definitiva e autônoma em relação a possíveis crises de governabilidade ou influencia da estabilização econômica, a ter o maior orçamento na União entre os Ministérios.
} 
A atitude política de romper com o pacto constitucional certamente não se tratou de um ato autônomo do ministro da previdência, mas obteve o respaldo da Presidência da República e do Ministério da Fazenda. De acordo com Gilson Carvalho, “Faltam declarações da época, publicadas em documentos oficiais ou da mídia, que comprovassem o acordo havido entre o Presidente da República, o Ministro da Fazenda Fernando Henrique Cardoso e o Ministro Britto. Tudo leva a crer que este acordo nunca ficou registrado e foi extra-oficial. Mas, pelo teor das conversas tidas com o Ministro Britto, sempre foi dito por ele que aquela providência tomada de suspender as transferências de recursos para a Saúde tinham sido decididas conjuntamente por ele, pelo Presidente e pelo Ministro da Fazenda” (Carvalho, 2002, p.90).

Mostra-se politicamente significativo, no entanto, o fato de Britto ter tido o apoio do Presidente da República e do então Ministro da Fazenda na articulação da sua saída da previdência logo após apropriação dos recursos da saúde. Carvalho utilizar as entrevistas realizadas por um jornalista do Mato Grosso na ocasião para relatar tal fato: "É pensando no futuro, portanto, que o próprio Britto está articulando sua transferência para o cargo de articulador político do Presidente Itamar Franco. Porque nestas novas funções ele acredita que poderá auxiliar tanto o chefe da Nação como o ministro da Fazenda, Fernando Henrique Cardoso. E, por conseqüência, aparecer mais e melhor que agora. Isto é tudo o que Britto precisa para consolidar sua posição de candidato do PMDB ao Governo do Rio Grande do Sul, nas eleições de três de outubro de 1994. E, quem sabe, até mesmo à sucessão do presidente Itamar” (Carvalho, 2002, p.83).

Os efeitos da "crise de desfinanciamento" da saúde, agravada com o confisco das contribuições de salário por parte da Previdência, mostraram-se evidentes 1) no "locaute" realizado pelos hospitais filantrópicos, quando mais de 100 mil unidades hospitalares conveniadas pararam por tempo indeterminado, e 2) na conseqüente repercussão que a suspensão do atendimento teve na mídia e sobre a opinião pública em relação ao SUS. O presidente da Associação das Casas de Misericórdias de São Paulo declarava aos jornais que “O SUS acabou, não existe mais”. Ademais, o vice-presidente da Federação Brasileira de Hospitais, Carlos Mansur, declarava aos jornais que a maioria dos hospitais não tinham condições de funcionar por falta de material. Há que se ressaltar que as casas de misericórdias eram as que mais sofriam com a crise de financiamento do SUS, tendo em vista que grande parte dos hospitais lucrativos havia saído do SUS, permanecendo apenas aqueles que não 
tinham condições financeiras para sobreviverem junto à concorrência privada e ao franco desenvolvimento do mercado de serviços suplementares, de seguros e de atendimento privado à saúde no País.

O projeto do SUS, em qualquer fase da reforma, e apesar do caráter mais participativo (em relação ao México) e, em especial devido à intenção de efetuar um amplo atendimento de saúde para toda a população, nos vários níveis de atenção médica, nunca foi um projeto liderado pela elite política inserida na esfera política, nem cooptado pela esfera econômica do setor saúde também articulada e dependente da esfera política. Lembremos que o SUS nasceu como um projeto contra-hegemônico de construção de um novo domínio público no atendimento à saúde. Sua cooptação pela política foi garantida mediante um processo de conquista de espaços na esfera política e apoiado e legitimado pelo processo de implementação e adesão crescente de atores da esfera política micro e social. Não representa, portanto, a expressão de uma unidade e identidade política nacional sobre o significado de público. Este sempre foi percebido e realizado como luta política por aquisição de espaços e recursos no Estado. Pelo fato da concepção do que é público confundir-se com o que é estatal, a própria crise fiscal do Estado no governo Itamar trouxe à tona um dos grandes paradoxos da construção do SUS: a sua crise de financiamento. Os setores não identificados com o SUS ou frontalmente contra o novo sistema, como a Federação Brasileira de Hospitais e o setor privado lucrativo, têm se utilizado claramente da crise de desfinanciamento do setor público, juntamente com a mídia, para produzir uma publicidade negativa do SUS junto à população em geral. Esta publicidade negativa também tem sido reforçada pela não identificação de médicos e administradores públicos com os valores universais do SUS, em especial nos sistemas hospitalares, onde predominam a medicina de segundo e terceiro nível, em que o profissional especializado identifica-se antes com a medicina médica lucrativa (do setor privado) e publicamente conhecida e divulgada como de alta qualidade. A atitude deste profissional tem possibilitado um processo de lenta mudança na percepção do usuário em relação ao público em construção.

Em tempo de prolongada instabilidade econômica, caracterizada por uma década de fracassos de choques heterodoxos, e após o fracasso do primeiro experimento de um neoliberalismo econômico, nos anos de Collor, a possibilidade de continuidade da construção do SUS encontrava-se relacionada 1) não apenas à possibilidade de se realizar uma nova 
construção social na atenção médica pública, mas também 2) à possibilidade de superação do alto nível de instabilidade econômica do país, que realimentava a crise de governabilidade em várias esferas da administração e, de forma particular, no setor saúde.

\subsection{O processo decisório no principio da estabilização econômica: o bloqueio da NOB- 94}

O novo plano econômico do governo só veio a público em 1994. O plano resultou de um articulação política realizada pelo terceiro ministro de Itamar, Fernando Henrique Cardoso, junto aos economistas que deram sua contribuição na arquitetação da nova estratégia, junto aos políticos tradicionais que garantiriam o apoio necessário junto a esfera política, e junto a parcela significativa do mercado financeiro internacional na venda dos títulos que garantiriam a negociação da divida externa e o conseqüente aporte financeiro necessário para atrelar a nova moeda ao dólar americano. Esta articulação política foi realizada paulatinamente pelo próprio Fernando Henrique Cardoso, com a adesão progressiva de aliados políticos e econômicos no decorrer de 1993 (Dimenstein e Souza, 1993) (Toledo, 1998). Análises políticas (Sola \& Kugelmas, 2002) (Sallum Jr, 1999 e 2003), bem como as próprias entrevistas de Fernando Henrique, revelam a virtú política do político-ministro na articulação do plano, e quem viria a ser o próximo Presidente da Nação. Compartilho da interpretação destes atores no que se refere à elaboração do Plano, e a forma como se deu a sua condução no princípio do processo de implementação. Tratou-se de um plano que ou poria em risco ou premiaria a carreira daqueles que estivessem envolvidos. A experiência política e conhecimento do então ministro o diferenciava dos economistas envolvidos no processo. Fernando Henrique Cardoso percebia que tal processo deveria ser realizado com economistas mais experientes na vida pública, com políticos com ampla articulação nacional e de peso na política macro, e com negociadores conceituados da dívida externa no mercado internacional. A equipe foi definida após algumas recusas, reencontros e persuasões finais.

Com o anúncio do novo plano de estabilização, a nova Norma operacional de 1994 (NOB-94), também elaborada sob a influência do movimento municipalista da saúde, foi totalmente vetada pelo Ministério da Fazenda, não saindo do papel. A prioridade política do governo direcionava-se para a estabilização econômica e atrelava a condução das demais

políticas públicas às diretrizes de contenção de gasto e ajuste fiscal do novo plano. A nova 
democracia só entrou numa rota de maior governabilidade política após a inserção mais definitiva (em relação ao período Collor) do neoliberalismo econômico na agenda política do governo.

A dinâmica do processo decisório do SUS no primeiro ano de Itamar evidencia que a crise de governabilidade - construída desde a Nova República e herdada do governo Collor não apenas se apresentou como tempo de oportunidade política para a construção da NOB-93, como também restringiu, sobretudo após a crise de Britto, a construção política do SUS à condução da política econômica do país. A construção do SUS, com efeito, mostrava-se em alguma medida do decréscimo da incerteza econômica e recuperação da crise de governabilidade política. Diferentemente da política pública de saúde, cuja construção política dava-se juntamente com a oposição do setor privado - que objetiva apropriar-se de parcela significativa do atendimento realizado no domínio estatal -, a política econômica teria a capacidade de realizar uma ampla coesão político-social, por parte das esferas políticas, sociais e econômicas, em torno de sua construção. Com feito, a ortodoxia econômica (valores) e seus atores políticos passariam a militar contra ou a limitar o desenvolvimento do SUS, tal como preconizado na Constituição e Normas anteriores.

\section{O processo político micro e o SUS: identificação com a política pública em tempo de crise de governabilidade}

O incremento da participação dos municipalistas em meio às incertezas políticas (re)vividas pela nova democracia possibilitaram uma nova mobilização política do movimento sanitário na política macro, no princípio do governo Itamar Franco. O novo instrumento de legalidade reivindicado pela autoridade sanitária do País apresentava diretrizes mais claras para a realização dos valores constitucionais e, assim, apresentava, para a prática política, novas possibilidades e limites políticos para a continuidade/aprofundamento do processo de construção do SUS. As decisões produzidas no processo decisório de tipo participativo seriam mais uma vez legitimadas pela gradual adesão dos municípios (ou estados) ao processo de habilitação do SUS. 


\subsection{Identificação do político: incremento da habilitação ao SUS}

Com a vigência da NOB-93 deu-se o início das transferências do Fundo Nacional de Saúde aos fundos municipais de saúde, o que representou a transferência direta de recursos a esses municípios, e muito maior autonomia na sua utilização. Dava-se início a um processo de aprofundamento da construção da descentralização em todo o país. Em 1995, 55\% dos municípios estavam habilitados a alguma dos estádios de gestão da NOB-93.

Esta maior adesão dos municípios no processo de descentralização, no entanto, caracteriza-se ainda como início de um processo de construção dos valores de universalidade e integralidade do SUS. A própria lógica de financiamento e repasse de recursos mostrou-se, na prática política micro, como limite político na produção de um nível maior de identificação com os valores do SUS e conseqüente desenvolvimento de um modelo integral de atenção médica pública, uma vez que o direcionamento de grande parte dos recursos continuava a ser realizado para a atenção hospitalar. Entretanto, o limite financeiro não bloqueou o avanço do processo.

\subsection{Identificação administrativa: herança hospitalar com crescimento dos programas de atenção básica}

Segundo Levcovitz (1997) os critérios de repasses mantinham a dicotomia de recursos transferidos para cuidados ambulatoriais e hospitalares. Cordeiro (2001) ressalta ainda que "Executavam-se os municípios em gestão semiplena, o que não induziu o desenvolvimento de um modelo assistencial baseado na integralidade e progressividade dos cuidados ao paciente, uma vez que os recursos para as ações ambulatoriais foram rigidamente limitados. A alocação de recursos a serem transferidos, por se basearem em séries históricas de produção de serviços, reproduziu as distorções resultantes de critérios baseados na oferta de serviços, portanto, não contribuiu significativamente para a promoção da eqüidade” (Cordeiro, 2001).

Dentre outras críticas efetuadas no período encontram-se 1) a redução do papel de planejamento e de coordenação dos subsistemas de alta complexidade que os estados deveriam ter no SUS, e 2) a prestação direta de serviços em regiões onde os municípios fossem desprovidos de recursos e de capacidade gerencial para a gestão do sistema local de saúde” (Cordeiro, 2001). De forma que, apesar de ter proporcionado um aceleramento inicial no processo de descentralização, em sua vertente municipalista, a descentralização da saúde 
ocorria sem que se desse o desenvolvimento da regionalização (coordenação por parte dos estados) e da integralidade do serviço em todos os níveis da atenção médica. Lembremos ainda, como já enfatizado, que a crise fiscal retardou o repasse de recursos do SUS, ocasionando o "bloqueio" dos hospitais filantrópicos conveniados, e a saída do setor privado lucrativo mais eficiente da rede pública-estatal.

Há que se reconhecer também que a qualidade dos serviços mostrava-se certamente desigual, tendo em vista, como exemplos, o fato dos municípios apresentarem distintas capacidades de organização, bem como ao fato da escassez de serviços essenciais congestionar o atendimento hospitalar, dificultando o acesso dos usuários aos tratamentos mais complexos.

O desafio da integralidade, no entanto, já começava a ser construído, desde o princípio da década, a partir das experiências de atenção básica de saúde, como vimos. Também inspirado no modelo cubano, foi criado em 1993 o Programa Saúde da Família de Quixá, no Ceará. E em 1994, este Programa foi incorporado à política estadual de saúde (Canesqui \& Oliveira, 2002) (Goulart, 2002). O programa também foi “espalhado por dezenas de cidades do Nordeste, de Minas, e chegado à periferia de cidades como Porto Alegre, Recife e São Luís”. Os resultados do PSF são descritos por Capistrano Filho:

"Reduziram-se as internações hospitalares por desidratação, aumentou a aderência de pacientes de hipertensão arterial, diabetes, tuberculose e hanseníase aos tratamentos prescritos. As ações de educação para a saúde, há tanto tempo apenas preconizadas, começaram a dar frutos: aumentou o numero de gestantes que completavam seis ou mais consultas de pré-natal, elevou-se a cobertura vacinal e a porcentagem de mães que amamentam seus filhos por mais de quatro meses.

A única grande cidade pioneira nesse programa, Niterói (RJ), também apresentou nas áreas de implantação resultados excelentes. Importante ressaltar que, nessa cidade, sede de uma universidade federal e vizinha do Rio de Janeiro, a cultura da busca espontânea de cuidados nos serviços que, alegadamente incorporam tecnologia de ponta, cedeu lugar ao apreço pela modalidade assistencial que assegura a reconstrução da relação de confiança médico-paciente, a continuidade e humanização dos cuidados” (Capistrano Filho, 1999, p. 90). 


\subsection{Identificação social: precária participação, e percepção difusa da sociedade sobre o SUS}

O incremento da habilitação traduziu-se no aumento do número de conselhos e conferências em todo o país. As comissões tripartites começam a ter um papel de destaque no processo de negociação no SUS (Heimann et al., 2000) (Silva, 2001) (Silva et al, 2002). O peso que a participação social revelará ter no processo de habilitação na NOB-93 só se mostrará mais evidente nos anos seguintes, como veremos.

No que se refere à percepção da população sobre o SUS, tendo em vista a persistência, em geral, da falta de qualidade da atenção hospitalar, sobretudo, bem como a permanência das práticas de socialização da corrupção e fraudes no domínio público, amplamente divulgadas na mídia, a percepção da população brasileira em relação ao SUS mostra-se controversa em geral ao SUS. Em termos gerais, não se verifica ainda, em 1993, uma percepção positiva em relação à atenção médica pública. A minha hipótese é de que essa mudança começa a se dá, de forma mais significativa, com a propagação das experiências de saúde de família em todo o país (após 1995 e sobretudo 1998), e com incremento das denúncias e queixas em relação ao setor privado medico e/ou supletivo (no PROCOM), o que se ocorrer a partir da criação de uma agência regulatória para o setor após 1998.

\section{A construção da legitimidade do SUS no governo Itamar}

Em geral duas questões chaves ganham relevo no processo do SUS, apresentando-se como consenso entre os atores: 1) a insuficiência de recursos em meio ao incremento da oferta com a universalidade e 2) a necessidade de se ter uma cobertura de saúde com maior resolutividade e qualidade. Com a legitimidade advinda da permeabilidade política e social construída pelo SUS no decorrer dos anos, a futura regulamentação do SUS (a NOB-96) de alguma forma expressará este consenso e, mesmo em meio a um processo de estabilização econômica, o SUS continuaria a ser construído no processo decisório, no nível macro, já num contexto diferenciado de relação da esfera política macro com a micro e com a esfera social. 


\section{Capítulo 10 - Construindo o SUS em tempos de democracia e de estabilidade econômica: o primeiro governo de Fernando Henrique Cardoso (de 1995 a 1998)}

"Não é possível fazer andar um projeto para a sociedade brasileira sem alianças". Fernando Henrique Cardoso, In: Toledo (1998, p. 37)

De forma semelhante à dupla transição política no México, foi tão-somente após um período prolongado de crise de governabilidade que se deu, no Brasil, uma inserção mais acentuada das propostas/recomendações de políticas públicas condizentes com novo liberalismo econômico. No entanto, o caso brasileiro diferencia-se do mexicano não apenas pelo fato do Brasil já se encontrar num processo de democratização política, mas, em especial, pelo fato da redemocratização ter possibilitado - particularmente no que diz respeito à saúde uma interação política pouco mais recíproca ou inter-dependente entre as esferas políticas macro e micro e a esfera social.

Para a nova coalizão política que assumia o poder no nível macro, a promoção da estabilidade econômica e, logo, da credibilidade política do Plano Real mostrava-se determinante para a manutenção da governabilidade política na nova democracia. É possível afirmar que esta era a percepção dos políticos de direita e empresários em aliança política com o Plano Real. Este ganhou um maior número de adeptos políticos e maior coesão políticosocial no princípio da implementação, cujo sucesso resultou na indicação e eleição do então ministro da Fazenda ao cargo de Presidente da República do Brasil.

Apesar da estabilização econômica ter se mostrado como o principal instrumento de coesão sócio-política e, portanto, de legitimação do poder político macro, não se apresentava como condição suficiente para a estabilidade do exercício do poder na nova democracia, caracterizada pela perpetuação de altos níveis de desigualdade social. O governo federal, em aliança com novas e velhas forças políticas, iria se defrontar, em inúmeras ocasiões, com a árdua tarefa de conciliar os interesses de sua coalizão política, de um lado, com os interesses gerais ou universais da população brasileira, de outro. Inaugurava-se uma etapa mais definitiva de reversão do desenvolvimentismo econômico no País, a qual se traduziu em modificações 
nas relações Estado/Sociedade (Sallum Jr., 1999 e 2003). Nesta etapa, a esfera econômica (ou da sociedade econômica) demandava sua independência em relação ao poder, a fim de criar um mercado para produtos e serviços até então sob o domínio público-estatal de um Estado de tipo desenvolvimentista. Lembremos que, no Brasil, o domínio público confunde-se com o estatal, e, dessa forma, a prática política do liberalismo econômico constitui-se em tempo de oportunidade política para a sociedade econômica reivindicar sua autonomia política e crescimento, isto é: para o empresariado e capital internacional em aliança com o poder (inseridos ou articulados com a esfera política macro) conquistarem novos nichos de mercado num país de tamanho continental ${ }^{134}$.

Já no que se refere ao processo decisório da saúde e, mais especificamente à continuidade da construção política do SUS, a autonomia reivindicada pela esfera econômica, em aliança com a esfera política macro, se traduzirá, ao final do primeiro governo de Cardoso, no incremento da subordinação da esfera política micro e esfera social da Saúde em relação à atuação econômica politicamente dominante na esfera política macro. Com efeito, a continuidade da construção política do SUS apresentará um sentido claro neste governo: será caracterizada por um conflito acirrado entre o Ministério da Saúde, de um lado, e Presidência/Ministério da Fazenda de outro. O conflito se dá em torno de um tema principal: a crise de financiamento do SUS, a qual punha em risco a possibilidade de realização concreta e continuidade de uma política pública com acentuado nível de legitimidade.

Este conflito entre política econômica e política de saúde mostra-se significativo pelo fato da Saúde apresentar-se como um setor gastador de recursos públicos federais. Observe que o governo federal é o principal financiador do SUS, e responsável em média por 75\% do gasto total entre 1980 e 1993 (Mendes, 1996), apesar do incremento constante do gasto de origem municipal sobretudo. Com o aumento da demanda por serviços públicos de saúde, decorrente sobretudo da universalidade, a inconstância nas transferências da União para as unidades subnacionais (agravada no período de Collor, e na “crise de Britto” em 1993) havia se mostrado politicamente perversa e, assim, acirrado a crise de financiamento do SUS no decorrer de sua implementação. Como ressaltado por vários autores, a crise de financiamento mostra-se como

\footnotetext{
${ }^{134}$ Dentre as medidas adotadas que visaram reverter o desenvolvimentismo e, por isto, atendiam aos interesses do empresariado e/ou capital internacional (financeiro sobretudo) destacam-se:
} 
um dos principais constrangimentos políticos na implementação do SUS (Viana, 1994) (Cohn, 1994) (Lucchese, 1996) (Médici e Marques, 1996).

\section{Processo decisório em tempos de estabilização econômica: política econômica versus política de saúde}

Dividiremos o processo decisório do SUS, no primeiro governo de Cardoso, em dois períodos: os dois primeiros anos em que Adib Jatene se encontrava na chefia do Ministério, e os dois anos seguintes em que Albuquerque e Serra ocuparam a pasta da Saúde na política macro. No primeiro período, apesar das tentativas de limitação do orçamento do SUS por parte do Ministério da Fazenda, verificou-se uma participação política mais expressiva do movimento sanitário na esfera política macro, evidente no 1) processo de elaboração da nova regulamentação do setor (NOB-96), 2) no fato do Executivo não ter logrado aprovar a PEC-32 no Congresso Nacional, retirando a proposta; e 3) na articulação política e social liderada por Jatene, em várias esferas, em prol da criação de uma contribuição tributária adicional especifica para a Saúde: a CPMF. O segundo período, por sua vez, é caracterizado pelo decréscimo relativo da participação do movimento sanitário e incremento da influência do Ministério da Fazenda sobre o processo de decisão do SUS. Destacam-se, neste período, 1) o bloqueio das demais transferências orçamentárias do SUS após a vigência da CPMF, já na gestão do ministro Albuquerque; 2) a conseqüente reativação do tema e luta pela vinculação orçamentária para a Saúde no Congresso Nacional, 3) e a edição de novas portarias do Executivo Federal para o SUS, já na gestão de Albuquerque (e Serra), as quais produziram mudanças significativas na NOB-96, e, por fim, 4) o início da implementação da versão modificada da NOB-96/98 com José Serra como ministro da Saúde.

\subsection{O processo decisório na gestão de Adib Jatene: a predominância dos interesses democráticos da Saúde}

"Nas discussões que mantive quando da minha passagem pelo governo, eu dizia ao pessoal da área econômica que eles estavam muito acostumados a lidar com a riqueza ... Convivem com a riqueza e, com o tempo, acabam tendo dificuldades para entender os problemas de pobreza ... Os profissionais de saúde, todos eles, convivem com a pobreza desde os seus tempos de faculdade. Por isso, não aceitam as limitações que a área econômica impõem ao setor” (Jatene, 1999, p.60).

Foi em meio ao contexto de crise de financiamento do SUS que Adib Jatene assumiu o Ministério da Saúde, onde ficou por dois anos apenas. Logo no princípio de sua gestão, o 
Executivo Federal enviou uma Proposta de Emenda Constitucional (PEC-32) para o Congresso Nacional, como tentativa de limitar o orçamento da Saúde. Sabemos que o governo Fernando Henrique Cardoso, no período, foi “bem-sucedido” em vários setores no que diz respeito a “solapar alguns dos fundamentos legais do Estado nacional-desenvolvimentista” (Sallum Jr., 2003,. P.44). Brasilio Salum Jr (2003), em sua análise sobre a mudança nas relações Estado/Sociedade no período, relata algumas das áreas antes do domínio público-estatal, transformadas em domínio privado pelo novo governo:

"os projetos de reforma constitucional e infra-constitucional submetidos ao Congresso foram quase todos aprovados, entre os quais se destacaram a) o fim da discriminação constitucional ao capital estrangeiro; b) a exploração, o refino e o transporte de petróleo e gás, monopolizados pela companhia estatal de petróleo (Petrobrás), foram transferidos para a União e convertidos em concessão do Estado às empresas, principalmente a estatal, que manteve grandes vantagens em relação a outras concessionárias privadas; e c) o Estado foi autorizado a conceder os direitos de exploração dos serviços de telecomunicação (telefonia fixa e celular, exploração de satélites, etc) a companhias privadas (anteriormente as empresas públicas tinham o monopólio dos serviços)” (Sallum Jr, 2003, p.44).

Na Saúde, no entanto, a recusa do Congresso em aprovar a Proposta de Emenda Constitucional Número 32 (PEC-32), resultante da pressão de representantes políticos do movimento sanitarista - infiltrados no Congresso desde o princípio da transição - ou de aliados políticos da Saúde articulados com a esfera política macro, revela o caráter diferencial do SUS em relação às demais reformas/políticas públicas já sob a influência direta dos interesses econômicos e da área econômica do governo.

De acordo com a proposta de Reforma da Seguridade Social (PEC 32), enviada pelo Executivo Federal ao Congresso em março de 1995, “a lei federal definirá os critérios de transferência de recursos para o SUS e Assistência Social da União para Estados, DF e Municípios e dos Estados para Municípios, observada a respectiva contrapartida de recursos”. Ademais, este critério de transferência deveria ser executado desde que fosse "observada a respectiva contrapartida de recursos”. Como ressalta Gilson Carvalho (2002), “essa hipótese que, à primeira vista, pode ser olhada como um bem, exigindo, principalmente de Estados e Municípios que entrem com recursos próprios para a saúde, na verdade pode ser indicadora de menos recursos da União para a Saúde. O pensamento dominante entre os economocratas é de 
que a União não poderia arcar sozinha com as despesas de saúde e teria que dividi-las com Estados e Municípios” (Carvalho, 2002, p. 151).

A proposta encontrou oposição por parte de parlamentares e sociedade civil organizada, desencadeando, por exemplo, a formação de um Grupo de Trabalho em defesa da Saúde e de uma Comissão encarregada de analisar a PEC 32 no Congresso, bem como a realização de negociações que objetivavam a retirada da Emenda pelo Executivo. Esta luta se estendeu até novembro, quando o Presidente da República solicitou a retirada da PEC-32. Observe que mesmo em tempo de estabilização econômica a Saúde apresentava-se mais uma vez (como já amplamente conhecida) como uma área potencial de conflito entre os principais atores da esfera política macro. Neste conflito, a questão da distribuição de recursos adquiria papel de destaque.

Outro evento importante do processo decisório do SUS no período refere-se à elaboração da Norma Operacional Básica do SUS de 1996 (NOB-96). Esta nova Norma “foi exaustivamente debatida na CIT, aprovada no Conselho Nacional de Saúde, submetida à X Conferência Nacional de Saúde e finalmente publicada em 11 de novembro de 1996" (Carvalho, 2002). A nova regulamentação mostrava-se como resposta direta a três problemáticas evidenciadas no decorrer do processo de implementação no nível micro. Tratava-se da necessidade 1) de avançar na autonomia municipal sobretudo, 2) de produzir mudanças na lógica perversa do modelo assistencial (herdado do INAMPS) e na organização da oferta de serviços e 3) de reforçar o papel das instâncias colegiadas.

A NOB-96 define novas condições de habilitação dos municípios e estados, visando alcançar gradativamente a capacidade plena dos municípios e estados na gestão do sistema. Os municípios passariam a ser habilitados em apenas dois estádios de gestão: "gestão plena da atenção básica” e "gestão plena do sistema municipal”. A habilitação dos estados também se pautaria na gestão avançada e gestão plena do sistema estadual. Para qualquer nível de gestão, previa-se a transferência automática de recursos fundo-a-fundo.

O Programa Saúde da Família (PSF) e o Programa de Agentes Comunitários de Saúde (Pacs) foram definidos como estratégias-mestras de reformulação do modelo de atenção à saúde. Criava-se um incentivo financeiro específico para estes programas. No caso dos municípios na condição de gestão plena da atenção básica, seriam transferidos fundo a fundo 
os recursos correspondentes à atenção básica, correspondendo ao Piso de Atenção Básica (PAB). Observe que enquanto o pagamento por serviços produzidos seria mantido para o sistema hospitalar, o PAB corresponderia a uma transferência automática de recursos, favorecendo a autonomia e a inovação em cada município. Ademais, com o PAB seria utilizado um parâmetro populacional, no lugar do parâmetro capacidade instalada, favorecendo os municípios e regiões mais pobres.

A inserção do Pacs e PSF viabilizaria mudanças na lógica assistencial hospitalocêntrica, que havia se propagado até então na implementação do SUS. A intenção era possibilitar uma queda/rompimento com a produção perversa de procedimentos hospitalares desnecessários, bem como viabilizar a atenção básica como porta de entrada do usuário para os níveis mais complexos e caros da pirâmide assistencial (Jatene, 1999). Observe que o PSF, diferentemente do PAC mexicano, não é concebido como um programa de redução da pobreza e sem nenhum relacionamento com níveis mais complexos de atenção. O objetivo final do PSF é promover a integralidade da atenção médica, proporcionando maior equidade na descentralização do serviço público de saúde.

A articulação política de um novo tributo para a Saúde também se mostrou politicamente significativa no decorrer da gestão de Jatene. O ministro efetuou uma ampla articulação política em torno da Contribuição Provisória sobre Movimentação Financeira (CPMF), junto a políticos e vários representantes do empresariado e sociedade civil e com o apoio da mídia. Tratou-se, na realidade, de uma campanha de convencimento, em termos nacionais, da relevância política que o novo tributo, considerado inconstitucional, teria para o setor saúde. Veja a declaração do então Ministro da Saúde:

“O Ministério da Saúde em 1995 executou um orçamento de R\$ 14,899 milhões, considerado insuficiente para, pelo menos, corrigir os valores de julho de 1994 quando se iniciou o plano real. Tanto que nos dispusemos a batalhar para obter novos recursos, que se somassem, em 96, ao que tínhamos no orçamento de 95 . deveríamos ficar portanto com $\mathrm{R} \$$ 18,613 milhões, mais 6 bilhões de arrecadação da CPMF, o que elevaria o orçamento para R\$ 24,750 milhões. Tal montante permitiria não só atualizar os valores de julho de 94 no atendimento médico ambulatorial (...) mas também ampliar o combate às endemias particularmente malaria e dengue - e deflagrar o programa saúde da família e dos agentes comunitários com impacto sobre a mortalidade materna e infantil” (Jatene, 1999, p.60). 
Esta campanha, apesar de algumas oposições, sobretudo da parte dos economistas e tributaristas, logrou formar um consenso sócio-político no País sobre a necessidade de superação da crise financeira do SUS. O intento era adicionar a CPMF ao orçamento já existente. No Congresso Nacional, Roberto Campos, adepto ferrenho do liberalismo econômico, em época de desenvolvimentismo ou de neoliberalismo, declarava seu apoio à CPMF: "Só mesmo uma situação de catástrofe como a da atual situação da saúde pública me levaria a votar para o que, afinal de contas, é uma perversão fiscal”. Esta luta pela CMPF durou dois anos, tendo sua aprovação retardada por um ano, ocorrendo o início de sua arrecadação apenas em 1997.

Há que se reconhecer ainda o esforço realizado na gestão de Jatene no combate à corrupção na Saúde, já após a extinção institucional do INAMPS, fato que se evidencia, por exemplo, na queda do número de internações e no fechamento de 200 laboratórios, alguns deles fantasmas (Jatene, 1999).

\subsection{O processo decisório nas gestões de Albuquerque e de José Serra: a predominância política da Economia.}

A aprovação da CPMF só ocorreu no período da gestão de Albuquerque, quando o Executivo Federal bloqueou grande parte do orçamento da Saúde, no intuito de incrementar a folga no orçamento federal. Observe que em 1997 o orçamento do Ministério da Saúde, incluindo a CPMF, foi de apenas R\$ 20,425 milhões, resultando num valor inferior ao de 1995, "esterilizando completamente a CPMF como recurso adicional e impedindo qualquer perspectiva de cumprimento das metas previstas quando da sua aprovação” (Jatene, 1999, p. $61)$.

Por fim, apesar de ter sido negociada e apresentada à população como recurso adicional necessário para o SUS, a CPMF acabou transformando-se na principal fonte de recurso da Saúde. Como reconheceu José Serra, na ocasião em que já era ministro, em 1998: “A saúde foi usada como pretexto para aprovação da CPMF. O imposto serviu para aumentar a receita do governo e não do setor. A CPMF substituiu outras fontes que deixaram de ser transferidas ao ministério. A CPMF é receita para o governo. Não é receita da saúde” (Serra, 1998 e 2000) ${ }^{135}$.

\footnotetext{
${ }^{135}$ Declarações feitas aos Jornais O Globo e Folha de São Paulo em 09 de outubro de 19998.
} 
Ademais, o programa de erradicação da dengue em 2.400 municípios, elaborado pela Comissão formada por Jatene, e que deveria ter sido posto em prática desde março de 1997 por um período de três anos, ainda não havia sido executado em 98. Como denunciado pelo próprio ex-ministro, "se espera a ocorrência de casos nos municípios para, só então, socorrê-los, ao invés de se partir para a erradicação total do mosquito. O programa previa a ordem total de R\$ 4 bilhões, significativa parte dos quais deveria provir da CPMF” (Jatene, 1999, p. 58). A crise de financiamento, também retardou a implementação da NOB-96, que havia previsto o repasse de recursos para as esferas sub-nacionais com base na expectativa de incremento do orçamento do MS, com o adicional da CPMF.

Foi o ministro Albuquerque, sob a influência direta do “vice-ministro” Barjas Negri, quem editou um conjunto de Portarias ${ }^{136}$ que alteraram profundamente a NOB 01/96. "Barjas Negri é tido como o homem de confiança do Presidente e de Serra (no Planejamento), vindo com uma recomendação de grande eficiência na implementação do FUNDEF” (Carvalho, entrevista 2003). Seguindo as pressões em curso, o então Ministro “vai ao Palácio do Planalto, com o aval do Presidente, assinar oficialmente as portarias, com todas as alterações, às 12 hs do dia 18 de dezembro de 1997. Depois da cerimônia, às 15:45 hs dá-se conhecimento à CIT do teor das portarias a que ninguém tinha tido acesso” (Carvalho, 2002). Após a edição das Portarias, o Secretário de Políticas de Saúde do MS afirmava publicamente que seus conteúdos haviam sido aprovados no CNS, na reunião de 3 e 4 de dezembro de 1997. No entanto, os conteúdos das novas portarias não apenas desconsideravam as discussões realizadas na CIT quando não houve consenso no que diz respeito a pontos principais e essenciais -, como também não tinham sido aprovados pelo Conselho Nacional de Saúde. "Havia ocorrido uma ampla participação de técnicos do MS, CONASS e CONASEMS na discussão dessas modificações na NOB-96. Ao final, houve uma suposta negociação final na CIT e no CNS” (Carvalho, 2002, p. 203). Dentre as principais modificações encontravam-se alterações nos critérios de alocação de recursos para a atenção básica de saúde.

Como ressalta Levcovitz e outros (2003), “A partir de 1998 algumas diretrizes políticas começaram a definir novos rumos para a política de saúde (...). Algumas portarias complementares (de janeiro, fevereiro e março) regularam os fluxos, habilitações e valores constantes na NOB, conferindo uma outra operacionalidade para a proposta” (Levcovitz et al.,

\footnotetext{
${ }^{136}$ Trata-se da portaria 1882 a 1923 de 28-12-1997, as quais regulamentam a implementação da NOB-96
} 
2003, p.45). Dentre as críticas efetuadas à NOB-96, destaca-se a de Bueno e Merhy (1998), para quem os incentivos de financiamento das ações de saúde se dariam de forma verticalizada, ferindo o principio de autonomia do gestor local. Isto ocorreria, porque a Norma induzia os municípios a aderirem ao Pacs e PSF como estratégia de modificação no modelo de atenção médica.

Em meio a crise de financiamento na saúde, e à luta travada entre o Ministério da Saúde, Fazenda e Presidência em torno do financiamento do SUS, mostra-se significativo o fato da implementação efetiva da NOB-96/NOB-98 ocorrer sob o comando de José Serra economista, político PSDBista e amigo pessoal do presidente -, no Ministério da Saúde. É possível que o convite, feito por Fernando Henrique Cardoso a José Serra, visasse contornar/amenizar os conflitos existentes. Também é possível que a intenção fosse dar início ao processo de implementação da reforma administrativa na Saúde, já sob o impacto da Reforma Gerencial do Estado, que ainda não havia atingido o SUS. A segunda suposição é desenvolvida por Rizzotto (2000), dentre outros, a segunda ainda há de ser devidamente investigada. A minha hipótese é que as duas intenções se complementam e mostram-se significativas para a compreensão do porquê político da mudança na chefia do MS. Fato, no entanto, é que, ao assumir a pasta da Saúde, como reconhecem alguns (apenas) nomes expressivos do movimento sanitário, o então ministro, mesmo com um compromisso distinto do dos sanitaristas com a Saúde, passou a defender e a lutar pela continuidade de construção do SUS.

Para Serra, a trajetória de construção do SUS deveria ser pautada no campo da “possibilidade política” (Serra, 2000), como ressaltava o ministro na sua posse. Lembremos, contudo, que a reforma brasileira surgiu como uma proposta contra-hegemônica, logo de oposição, reivindicando uma transformação de escopo amplo (radical) no domínio público. Meu argumento é que a estratégia de "possibilidade política” proposta pelo novo ministro, poria limites à atuação política vocacionada e contra-hegemônica do movimento sanitário ${ }^{137}$,

\footnotetext{
${ }^{137}$ Praticamente todos os sanitaristas entrevistados se queixaram, acirradamente, da atuação dos novos técnicos de saúde integrados ao MS, que passaram a compor a chefia de secretarias na gestão de Serra. A discordância, devese ressaltar, advém da forma como o economista e técnico de administração pública compreendem a saúde e interpretam os problemas práticos do SUS. O envolvimento do sanitarista da medicina coletiva brasileira, mesmo quando detido na academia tão-somente, não se restringe ao nível da administração e quantificação/análise de recursos, mas implica em envolvimento com a prática política e médica e com o usuário. Este envolvimento mais complexo, que resulta numa compreensão igualmente complexa sobre o significado de saúde, o acompanha desde o dia que foi iniciado na saúde pública brasileira. Para a maioria dos sanitaristas, apesar das intenções políticas
} 
pautada no possível e no impossível. Era como se o governo tivesse abraçando, de forma diferenciada do projeto inicial, a causa do SUS e, assim, criava-se um novo tempo de oportunidade de mudança no setor, condizente com a ordem política vigente. Com feito, foi sob o comando do ministro Serra, a partir de 1998, que se viabilizou política e financeiramente o aprofundamento e aceleramento do processo de descentralização.

\section{Implementando do SUS em tempo de estabilização econômica}

Na medida em que a estabilização econômica mostrou-se politicamente significativa para a governabilidade e legitimidade política do novo governo, o novo cenário de mudança criava constrangimentos financeiros para a implantação do SUS pela NOB-93. Vejamos em que termos as constrições econômicas se traduziram ou não em limites políticos para o processo de legitimação do SUS na esfera política micro, na continuação do processo político da NOB-93.

\subsection{Crise de financiamento com Identificação política}

Em 1995, o processo de implementação da NOB-93 paralisou durante meses, sendo retomado e aprofundado posteriormente. O governo federal ainda se manterá como o principal financiador do SUS, e os municípios continuarão despendendo parcelas significativas de seus próprios orçamentos no setor saúde. Pesquisa realizada pelo Instituto de Saúde (da Secretaria Estadual de São Paulo) em doze municípios brasileiros revela que os municípios já empregavam grande parte de seus recursos próprios no setor saúde (Heimann et al, 2000). Ademais, a pesquisa "Sistema de Informação sobre o financiamento de saúde dos municípios”, realizada pelo CEPAM-USP ${ }^{138}$ em municípios de São Paulo, também demonstra que recursos próprios dos municípios paulistas mostravam-se como principal fonte do gasto em saúde, entre 1995 e 1999 (Mendes \& Santos, 2000).

evidentes de Serra, e de um certo comprometimento com a saúde por parte do então futuro candidato à presidência - após a segunda gestão de Fernando H Cardoso -, Serra não apenas realizou transformações tidas como neoliberais na Saúde, como também possibilitou a propagação de velhas práticas patrimonialistas no uso do recurso público. As queixas relatadas na ocasião das entrevistas, advinham do fato destes sanitaristas (ou amigos próximos) estarem assumindo a liderança do MS e de suas secretarias, herdando as problemáticas fomentadas pela gestão anterior. A análise política mais detida da gestão de José Serra será efetuada em ocasião oportuna. Deixo aqui apenas algumas considerações e hipótese.

138 Fundação Prefeito Faria Lima 
A retomada da habilitação pela NOB-93 implicou no aprofundamento do processo de descentralização na saúde. Observe que em 1996 "mais de 60\% dos municípios haviam se integrado ao processo de descentralização indicando tendência crescente de adesão política. Do total dos que aderiram a uma das formas de gestão previstas na NOB 01/93, a maioria ingressara na modalidade incipiente, $12 \%$ se encontravam em condição parcial de gestão e 2,5\% operaram na condição semiplena de gestão” (Heimann, 2000, p.35).

Contudo o peso que a Saúde passou a ter na agenda política local, bem como a forma como os recursos foram utilizados variaram muito. No que se refere aos efeitos políticos perversos na construção da Saúde como um domínio público, destaca-se o caso da cidade de São Paulo. Foi neste período que o processo de construção do SUS foi interrompido pelo prefeito Paulo Maluf (1993-1996). O novo prefeito criou o seu próprio programa de saúde (o PAS), cuja implementação produziu uma alocação patrimonialista do recurso público entre a clientela malufista, realizando uma privatização perversa no setor (Elias, 196). De outro lado, dentro da própria cidade de São Paulo foi construída uma prática modelo de atenção básica, com o QUALIS/PSF, adotado a partir de 1996 pela Secretaria Estadual de Saúde (Capistrano Filho, 1999).

Em Campinas, assim como em milhares de cidades no País, representantes do movimento sanitário encontravam-se no comando e/ou em cargos de chefia nas Secretarias Municipais de Saúde no decorrer da implementação do SUS. Carmem Lavras assumiu a Secretaria Municipal de Saúde na segunda gestão de Magalhães na prefeitura, em 1993. De acordo com a ex-secretária, a sua ida para a chefia da SMS revelou que ainda havia uma forte identidade entre os atores que haviam estado na luta pela saúde na ocasião da gestão de Sebastião Moraes. O grupo que havia se mobilizado na década 70, construindo postos de saúde nas áreas mais pobres da cidade, retornava à Secretaria para implementar a gestão semi-plena do SUS (Lavras, entrevista 2003).

O processo de habilitação ao SUS aprofundou-se com a implementação da NOB96(98), iniciada apenas em 1998. Neste ano 85\% dos municípios aderiram à nova Norma, mesmo em ritmos diversificados entre as regiões brasileiras (IBGE, 2001). Com os novos mecanismos de repasse para a atenção básica, os quais se traduziram em incentivos políticofinanceiros de habilitação ao SUS, 89\% dos municípios estavam na condição de Gestão Plena da Atenção Básica e 10\% na de Gestão Plena do Sistema em 1998 (IBGE, 2001). Em Marília, 
por exemplo, o retorno do mesmo prefeito do período de 1983 a 1988 ao comando do governo, após a eleição de 1996, possibilitou uma nova articulação dos aliados do movimento sanitário na esfera política micro. Com efeito, os mesmos atores que haviam influenciado o princípio da implementação do SUS em Marília adotaram como uma das estratégias principais "preparar o município de Marília para habilitar-se à gestão plena do sistema municipal” (Silva, 2001, p. 209).

\subsection{Identificação na gestão da atenção à saúde? velhas e novas práticas de assistência médica}

A estabilização econômica, articulada com a crise de financiamento do SUS, mostrouse distinta nos municípios brasileiros e entre os níveis de atenção médica, em 1995. A crise mostrou-se mais perceptível na paralisação dos hospitais, sobretudo dos filantrópicos. Neste momento, verificou-se um baixo nível de identificação com os princípios do SUS por parte dos administradores e funcionários públicos e conveniados filantrópicos com o SUS. Há que se destacar ainda que entre julho de 1994 e setembro de 1997 não houve reajuste na tabela paga aos prestadores do SUS. Com uma inflação acumulada superior a 80\% concedeu-se, no máximo, um abono de 25\%.

Os efeitos da crise de financiamento entre as unidades federativas sobre a gestão da Saúde, no decorrer da implementação do SUS, também se mostraram videntes na área de saúde pública, com as epidemias de sarampo, cólera e dengue. Ademais, doenças que antes estavam sob controle cresceram em alguns pontos do país, como é o caso da tuberculose, malária e hanseníase. Apesar destes focos de epidemia, acentuados no período de crise de financiamento, as análises do Centro Nacional de Epidemiologia (CENEPI) ressaltam a ocorrência de melhora significativa nas condições de saúde da população desde a implementação do SUS, com destaque para o decréscimo da taxa de mortalidade por epidemias para todo o período. Entre 1980 e 1996 a mortalidade para os menores de 1 ano passou de 23,98\% para 8,19\%, e a mortalidade entre as crianças de 1 a 5 anos que correspondia a 4,61\% em 1980, atingia apenas 1,414\% em 1996.

A crise do financiamento público também produz efeitos sobre a estrutura física e humana do setor. Um dos paradoxos do processo do SUS, como ressaltado por Médici, é que “o crescimento da capacidade instalada do setor público em saúde não tem sido correspondido 
por uma expansão do emprego médico. Tanto em termos de produção de serviços como de absorção de insumos, o setor privado tem crescido proporcionalmente mais que o setor público” (Médici, 1997, p. 25)

De outro lado, no entanto, verifica-se um crescimento da atenção médica básica no País no período, traduzindo-se em novas e distintas formas de articulação com a atenção hospitalar. Tal fato evidencia que o SUS também se apresenta como possibilidade política concreta de realização de novas formas de socialização na assistência à saúde no domínio público, com possibilidade de integração do sistema básico aos níveis mais complexos da atenção. Os limites políticos institucionais de mudança de modelo na atenção, apesar dos efeitos perversos desencadeados, não bloquearam o processo de construção. Em 1994, quando criado, o PSF compreendia apenas 328 equipe, cobrindo tão-somente 55 municípios e 1,1 milhões de habitantes (Canesqui \& Oliveira, p. 253). Em 2001 o PSF estava implantado em 66\% dos municípios, apresentando uma população coberta estimada em 43,8 milhões, ou seja, 25\% da população (IBGE, 2001). Dados do IBGE demonstram ainda que a cobertura do Programa é maior na Região Nordeste (38\%) e menor na Sudeste (17\%). Estudos têm revelado que a maior integração da população à atenção à saúde, com o PSF, não se dá de forma uniforme, variando conforme a política local e o peso que a Saúde passa a ter na agenda política (Goulart, 2002) (Silva, 2001).

Os efeitos perversos ocasionados pela crise de financiamento sobre a atenção médica no domínio público, mostraram-se certamente como constrangimentos para a construção dos princípios de universalidade, integralidade e eqüidade do SUS. No entanto não interromperam o processo de construção do SUS na política macro e micro, como ocorreu no México.

\subsection{Identificação social: participação social limitada pela política local, opinião pública em fase inicial de mudança}

No Brasil, o processo de democratização com descentralização não possibilitou a realização plena de um sistema de saúde participativo com controle social, tal como idealizado pelo SUS (Pinheiro, 2001), uma vez que “Os espaços institucionais de participação na formulação e controle de implementação das políticas sociais - os Conselhos - tendem a ser ocupados exatamente por representantes dos setores organizados (e portanto pelos incluídos)” (Cohn, 1999b, p.191). Tendo em vista a prevalência dos interesses já organizados e articulados 
com a esfera política local, os conselhos são utilizados não apenas para debates dos problemas evidenciados no processo do SUS, mas também para aprovação e legitimação dos atos dos Executivos municipais, sobretudo (Mendes, entrevista 2003).

É certo que, na democracia brasileira, a participação social no processo decisório local não se traduz como um espaço público, como ocorreu nas democracias burguesas (Habbermas). Não tivemos um espaço público burguês, autônomo ao domínio estatal, e sim a inserção de setores sociais e econômicos organizados no Estado. Ao surgirem dentro da própria esfera estatal, os conselhos revelam-se não apenas como possibilidade para a participação social, mas em especial como lócus para legitimação das decisões do Executivo (e de formas distintas de articulação com o Legislativo municipal ou estadual). Esta tensão varia conforme o jogo político local, como tem ressaltado a literatura (Heimann et al, 200) (Goulart, 2002) (Silva, 2001).

No entanto, há que se reconhecer que alguns avanços foram alcançados no que se refere à participação da sociedade e implementação de formas de responsabilização (accountability) na construção da universalidade e integralidade. A Pesquisa Municipal Integrada (PMU) realizada pela Fundação SEADE em 645 municípios paulistas ${ }^{139}$, revela que, mesmo de forma diferenciada, os municípios têm se adequado aos princípios do SUS (Silva et al., 2002). De acordo com os dados informatizados pela PMU, 97\% dos municípios já tinham conselhos implantados em 1997, embora apenas 28\% deles haviam realizado conferências municipais de saúde. A PMU revela ainda que 79\% dos municípios já haviam organizado bancos de dados em saúde em 1996 e os utilizavam na prática de gestão e alocação de recursos. Tal fato, aponta a pesquisa, apresenta-se como indicativo do comprometimento do sistema municipal com o aumento da eficiência e geração da eqüidade (Silva et al., 2002).

A pesquisa do Instituto de Saúde (SES-SP) também constata avanços positivos nos 12 municípios pesquisados no que diz respeito ao controle social:

“Afora as propostas de arranjos institucionais de iniciativa do poder executivo federal, em seus diversos níveis, os próprios conselhos de saúde avançaram na sua articulação, promovendo cursos de formação em finanças públicas para melhor controle dos gastos públicos em saúde (....) Registre-se ainda o recente movimento de aproximação entre os

\footnotetext{
139 Trata-se da Pesquisa Municipal Unificada - PMU 1992, 1995 e 1997.
} 
diversos conselhos de saúde e o Ministério Público, numa tentativa de conferir maior poder de sanção aos constantes desrespeitos, por parte do poder executivo, às deliberações desses fóruns do SUS” (Heimann et al., 2000, p.102)

No que se refere às mudanças na opinião pública e/ou dos usuários em relação ao SUS, os processos também se mostram complexos e paradoxais. De um lado, um estudo qualitativo sobre o acesso dos usuários às unidades básicas de Feira de Santana, na Bahia, com o objetivo de analisar a percepção dos usuários quanto às características dos serviços, mostra que o acesso aos serviços é focalizado e seletivo para responder a uma determinada queixa, tecnologicamente atrasado e discriminatório, dirigido ao usuário de baixa renda que tem menor qualificação no setor formal da economia e à população excluída socialmente (Assis et al, 2003).

De outro lado, no entanto, outras análises sobre a implementação de novas práticas de saúde e, em especial, do PSF, em cidades de pequeno e médico porte, sobretudo, demonstram que o desenvolvimento das novas práticas médicas, em particular por desencadearem novos tipos de relacionamentos/envolvimento realizados no cotidiano junto à sociedade, têm contribuído para modificar a percepção do usuário em relação ao SUS (Bueno, 1997) (Pinheiros \& Mattos, 2001) (Goulart, 2002) (Bodstein, 2002) (Pinheiros e Mattos, 2002). Ademais, o percentual alto de queixas do setor médico e supletivo no PROCOM, em contraposição ao baixo nível de reclamações em relação ao SUS, também indica a possibilidade de estar ocorrendo ou de desenvolvimento de mudanças positivas da opinião pública em relação ao SUS.

Há que se destacar ainda que o setor privado de saúde, em aliança com a mídia, tem se utilizado da crise de financiamento (Kucinsky, 2002) e dos escândalos de fraude, corrupção e baixa qualidade na atenção médica do SUS para argumentar junto à opinião pública que a crise é determinada pelo corporativismo e ineficiência do Estado. Tal argumento apresenta-se, em última instância, como uma campanha pela privatização dos serviços público-estatais de assistência médica especializada, legando ao Estado a responsabilidade pelas ações básicas de saúde e pelas medidas de saúde pública. Neste contexto, a percepção da sociedade brasileira sobre o SUS mostra-se em geral ainda negativa tendo em vista a falta de regulamentação dos serviços privados, até 1998, e o precário controle da ANVISA no pós 1998 sobre a atuação dos diversos segmentos de mercado de planos/seguros de atenção saúde. Tal fato assevera que a 
dificuldade de atendimento de direitos recentemente conquistados não se dá apenas no domínio público-estatal, mas também no domínio privado da esfera econômica. Ademais, problemáticas relacionadas às mudanças na prática médica não é exclusiva ao domínio público-estatal, também é peculiar ao mercado, uma vez que paz parte da cultura patrimonialista brasileira que permeia ambas esferas.

O aprofundamento do processo de habilitação, juntamente com a implementação de programas de APS visando à integralidade na atenção médica na construção de um novo domínio público, sugerem que se inicia um novo processo de socialização no SUS. As pesquisas aqui utilizadas assinalam que houve um avanço em relação ao comprometimento do político com a Saúde, um avanço na administração da gestão, o princípio da reversão do modelo público hospitalocêntrico “a partir de baixo”, uma continuidade na implementação dos conselhos, o desenvolvimento de novas formas de controle social e de responsabilização, e já o princípio (ainda muito incipiente e diversos entre os municípios e estados) de um processo de mudança na opinião pública em relação ao SUS. Com efeito, é possível sugerir que, após 30 anos, desde o inicio das primeiras experiências comunitárias e programas básicos (PIASS), o processo político do SUS, na esfera micro, apresentou-se um crescimento no nível médio de identificação, passando do nível baixo1, nos anos de Itamar, para o segundo patamar do nível Médio de identificação, nos anos de Cardoso ( $1^{\circ}$ governo).

\section{Legitimidade e construção do SUS: nos anos de Zedillo e Cardoso (1º governo)}

Em resumo, há que se ressaltar que apesar da estabilização econômica ter acirrado os conflitos em torno do financiamento SUS, possibilitando a revelação de alguns efeitos sociais perversos na implementação do novo sistema, não se verificou uma interrupção prolongada no processo, nem mesmo um decréscimo na adesão dos políticos locais ao sistema. O SUS, apesar da prática política perversa de Maluf em São Paulo, e dos efeitos sociais perversos advindos da crise de financiamento, bem como da perpetuação de práticas patrimonialista no domínio público-estatal, continuou apresentando um avanço, embora lento (porque contraditório), no nível de identificação por parte do político local. As tensões relacionadas ao conflito federativo, à mudança de modelo assistencial e à participação e percepção da sociedade civil em relação à Saúde revelam que os avanços conquistados superaram as dificuldades e obstáculos na construção do SUS. No decorrer da implementação da NOB-93, nos anos do 
governo Cardoso, a identificação média da esfera política micro posicionou-se no segundo patamar do nível Médio.

É possível afirmar ainda que os atos do Executivo Federal, no que diz respeito à suspensão do repasse de recursos orçamentários para a Saúde (com a crise de Britto e após a adoção da CPMF), diminuíram a inter-dependência existente entre a política macro e micro, revelando a existência de um deslocamento entre os interesses dos atores políticos dominantes na esfera política macro, de um lado, e os atores representativos da esfera política micro e movimento sanitário, de outro. Ta fato explica o porquê de representantes do movimento sanitário, bem como pesquisadores do setor, se mostrarem críticos ao neoliberalismo econômico após o período de Collor (Heinmann, entrevista 2003) (Roseni, entrevista 2003) (Onoko, entrevista 2003). Explica também o porquê dos sanitaristas envolvidos em novas práticas cotidianas na Saúde, as quais resultaram em novas formas de vínculo com o usuário, se mostrarem não apenas críticos, mas céticos em relação ao poder macro, no período entre Collor e Cardoso (Pinheiro, entrevista 2003) (Bodestein, 2002).

Tal deslocamento entre interesse da coalizão dominante e demanda do movimento sanitário, o qual diminuiu a dependência recíproca entre Estado e Sociedade na nova democracia, produziu-se apenas na medida em que a política de saúde mostrou-se frontalmente contra as diretrizes da política econômica ortodoxa, como também ficará claro no período de Serra (sobretudo no segundo governo de Cardoso). Apesar da Saúde mostrar-se subordinada à política econômica, o reconhecimento da legitimidade política do SUS por parte do Executivo Federal evidencia-se ao tentar buscar novas formas-institucionais (legais e financeiras) que viabilizem a continuidade da construção: mas desde que não sejam contrárias à condução do Plano Real. E, por fim, a própria autoridade política macro utiliza-se não apenas da estabilização econômica, mas também do SUS para se legitimar junto à população em geral (e em especial sobre a mais carente).

\section{Política e Saúde no segundo governo de Cardoso: notas comparativas sobre o processo de legitimação da Saúde}

O PSF foi implementado em nível nacional apenas a partir de 1998, num cenário de estabilização econômica e ajuste fiscal, como estratégia política para acelerar o processo de inclusão do SUS, e de melhoria nos índices de saúde. Foi a principal estratégia política do 
ministro José Serra, candidato oficial de Fernando Henrique Cardoso para a sucessão presidencial. Observe que tivemos um neoliberalismo atípico na saúde, com constante incremento do gasto no setor (Gouveia e Palma, 1999). Os conflitos entre o então Ministro da Fazenda e o Ministro da Saúde eram constantemente revelados nos jornais. Apesar de existirem críticas, por parte de setores mais progressistas da saúde coletiva, em relação ao fato de parte do programa ser financiado pelo Banco Mundial, bem como ao risco do programa ser utilizado para focalizar a propostas amplas de mudança do SUS, o fato é que mesmo os autores que fizeram estas criticas, como Emerson Elias Merhy (e Wanderley Bueno), hoje reconhecem que o PSF não virou um projeto neoliberal, uma vez que o Banco não conseguiu modificar as diretrizes do programa, que se encontram atreladas às diretrizes do SUS. De acordo com Emerson Elias Merhy, “o Banco Mundial capturou o PSF brasileiro” (Merhy, entrevista $2003)^{140}$.

A nossa hipótese em relação ao período em que Serra esteve no MS, em especial não segundo governo de Cardoso, é que o SUS e em particular o PSF foram utilizados pelo governo federal a fim de se legitimar no poder ${ }^{141}$. Tendo em vista a credibilidade política do PSF, distinta do caso mexicano do PAC, em virtude do alto nível de adesão política ao programa (Silva, 2001) (Capistrano Filho, 1999) (Goulart, 2002), cabe investigar em que termos o PSF apresenta um maior nível de aceitação e de legitimidade política em relação aos programas de APS nos outros dois países.

Num governo democrático com uma das maiores cargas tributárias do mundo, e cujo processo de privatização (das empresas estatais) diminuiu as funções do governo e, assim, ressaltou a sua função social, mostra-se politicamente significativo para o poder empregar os recursos públicos mais além da manutenção da credibilidade econômica. As mobilizações sociais do México em 1994, e mais recentemente, a revolta popular na Argentina, apontam para a necessidade de se impor limites no uso de recursos de poder na manutenção da estabilização econômica nas novas democracias: demonstram que os recursos devem ser deslocados tanto para fundos de estabilização quanto para fundos sociais, como a Saúde.

${ }^{140}$ Veja também o segundo capítulo da tese de Goulart (2002), bem como o livro de Silva (2001), ambos na bibliografia.

${ }^{141}$ Veja os textos que se encontram(vam) no site do PSB, na ocasião em que Serra concorre(ia) para o cargo de prefeito da cidade de São Paulo: "Serra consolida combate à AIDS", "Revolução da saúde (parte 1 e 2)", "Guerra das patentes: a grande conquista de Serra”. Acesso em 27/07/2004. http://www.psdb.org.br. 
Apesar da existência de uma certa inter-dependência da decisão do Executivo Federal/Fazenda em relação às esferas social e política micro, há que se reconhecer que foi sobretudo a atuação comprometida de representantes do movimento sanitário na esfera política macro (mesmo que de forma menos acentuada em relação aos anos anteriores), e a reciprocidade política verificada na esfera micro, com o avançado progressivo da implementação do SUS desde o PIASS até a NOB-93, que nos permite compreender porquê o SUS, mesmo em tempo de estabilização/ortodoxia econômica, continuou a apresentar um alto grau de continuidade, em especial quando comparado com a reforma mexicana no período de Zeddillo. No Brasil, as novas regulamentações da reforma de saúde, reivindicas como legítimas pelos atores participantes no processo decisório no nível macro, resultaram de uma articulação política mais inter-dependente entre esfera política macro e micro e esfera social e, por isto, implicaram decisões por diretrizes e legalidades menos deslocadas da realidade política e social, uma vez já estavam sendo realizadas nas esferas políticas micro, embora em diferentes formas e ritmos entre os diversos municípios/ou estados. No que se refere ao PSF, note que a prática antecedeu à decisão macro, tal como ocorreu com os movimentos comunitários de saúde e princípio do SUS, nos anos 70 e 80, em relação às Leis fundamentais do SUS. A accountability da construção do SUS surgiu - embora multi-forme e ainda problemática - têm surgido lenta e paulatinamente de mudanças no relacionamento. Tal processo, como vimos na análise de Zedillo, ainda não se verifica na reforma mexicana, legalizada a partir da esfera macro, com pouca influencia da esfera micro local e nenhuma influência de movimentos sociais na saúde.

\section{Considerações sobre a dinâmica sócio-política da reforma brasileira: a perspectiva micro-macro}

A dinâmica sócio-política do processo de dupla construção do SUS, de 1985 a 1998, permite-nos ressaltar que os paradoxos e efeitos perversos vindos à tona no decorrer do processo de implementação do SUS mostram-se menos perversos em relação ao processo de reforma da saúde para a população não-assegurada no México. No Brasil não tivemos o recomeço de uma nova política pública de Saúde, a cada princípio de governo na esfera macro, uma vez que a crise de governabilidade política não se confundia com a baixa viabilidade política da reforma pública reivindicada como legítima pelo governo anterior. O processo de construção do SUS mostra-se excessivamente lento, devido aos conflitos e paradoxos vindos à 
tona num contexto de dupla transição, bem como por causa da perpetuação das práticas perversas de apropriação privada do domínio público. Nossa sugestão é que tal processo caracteriza-se menos como uma problemática de consolidação democrática, e mais como uma problemática de construção política e social.

Nas democracias sociais no pós Segunda Grande Guerra - seja em sua vertente americana ou inglesa -, a consolidação democrática deu-se concomitantemente com a reprodução de um processo de integração sócio-econômica. No Brasil, por sua vez, a extensão do acesso da população aos serviços de saúde traduz-se mais como uma problemática de construção de uma nova legitimidade sobre o significado de público. Se avaliarmos a implementação do SUS do ponto de vista de direitos sociais e conquista da cidadania, tãosomente, associaremos o processo de mudança a conceitos consolidados em sociedades nas quais se verificavam as pré-condições para a concretização de um direito social. Neste sentido, a contribuição do cientista social se mostrará limitada a avaliações negativas sobre o sentido político de um domínio público ainda em construção, e com possibilidade de avanços no que diz respeito a uma lenta realização do direito à saúde.

Sugerimos que o SUS seja analisado politicamente mais além da problemática da consolidação democrática, isto é: como um processo de construção específico a uma sociedade periférica, em que a luta pela origem e desenvolvimento de um novo domínio público universal, com integralidade e eqüidade -, ainda mostra-se permeada por valores e interesses portadores de uma identidade patrimonialista: em que o domínio público tem sido não apenas confundido com o estatal, mas também realizado como domínio privado. O SUS, nas diversas fases da reforma, e distintamente do caso do México, tem possibilitado o surgimento de novas formas de socialização no decorrer de sua construção, como demonstram as novas práticas assistenciais, sobretudo na atenção básica, implicando em novos vínculos no relacionamento entre usuário-cidadão e o médico/funcionário público. Os sucessos das práticas assistenciais inovadoras na atenção serão comprovados com o PSF e com os milhares de experimentos em implementação no final da década (Goulart, 2002) (Pinheiros e Mattos, 2001 e 2003), 


\section{Conclusão - Legitimidade e comprometimento político na construção da reforma pública de saúde no México e Brasil: o caso da estratégia de descentralização para a população aberta}

“O destino de nossos tempos é caracterizado pela racionalização e intelectualização e, acima de tudo, pelo 'desencantamento do mundo'. Precisamente os valores últimos e mais sublimes retiraram-se da vida pública. (...) Se tentarmos construir intelectualmente novas religiões sem uma profecia nova e autêntica, então, num sentido íntimo, resultará alguma coisa semelhante, mas com efeitos ainda piores. E a profecia acadêmica, finalmente, criará seitas fanáticas, mas nunca uma comunidade autêntica” (Ciência como vocação, Max Weber, 1979, p.182-3)

Com vimos neste trabalho, e amplamente divulgado pela literatura de políticas públicas ou reforma do Estado, tanto Brasil (1985-1998) como México (1982-2000) ainda não foram capazes de implementar os valores e diretrizes das respectivas reformas públicas de saúde para a população aberta. Esta dificuldade, no entanto, possui diferenças politicamente significativas nos dois países, uma vez que o processo da política pública (decisão e de implementação) decorre de distintos padrões de relacionamento entre esfera política macro e micro e esfera social. Neste capítulo final pretendemos, primeiramente, ressaltar as conexões existentes entre “padrões de participação direta” na decisão e "níveis de identificação” no processo de construção da política pública de descentralização da saúde, em cada país e comparativamente, nas duas últimas décadas. Em seguida, estabeleceremos associações analíticas entre padrões de participação direta (de PDD), legitimidade e comprometimento da decisão política macro com a reforma pública de saúde para a população aberta.

\section{Participação direta e identificação na construção de um novo domínio público na saúde}

Tanto no processo de descentralização da política pública de saúde brasileiro (19821998), quanto no mexicano (1982-2000), separadamente, o incremento das pressões de domínio da política econômica neoliberal, na decisão macro, foi acompanhado por um declínio relativo da influência indireta de movimentos sociais, no México, e da influência indireta e direta de mobilizações de saúde no Brasil, na década de 90. Esta correlação inversa verificouse 1) gradativamente no decorrer do longo processo de transição de regime político no México 
(praticamente desde meados do governo de Portillo, em 1979), e 2) num período mais avançado da democratização brasileira a partir de 1990, com o governo de Collor (Quadro 11.1). Nas duas seqüências de transição político-econômica, as novas coalizões políticas da esfera macro valorizaram os requisitos de domínio da política econômica neoliberal ${ }^{142}$, produzindo alterações nas relações Estado/Sociedade. Este processo afetou diretamente, embora de forma distinta, a re-definição dos respectivos domínios público-estatais de saúde. Ressaltamos, assim, que a estabilização econômica, embora em tempos e seqüências distintas de dupla transição política, adquiriu um status de eminência no processo de dominação, no México e no Brasil, subordinando as demais políticas públicas, como a de Saúde, a um segundo plano no âmbito da decisão da política macro.

Quadro 11.1- Identificação e legitimação: avaliação política compreensiva e comparativa do processo da reforma pública de saúde para a população aberta no México e no Brasil

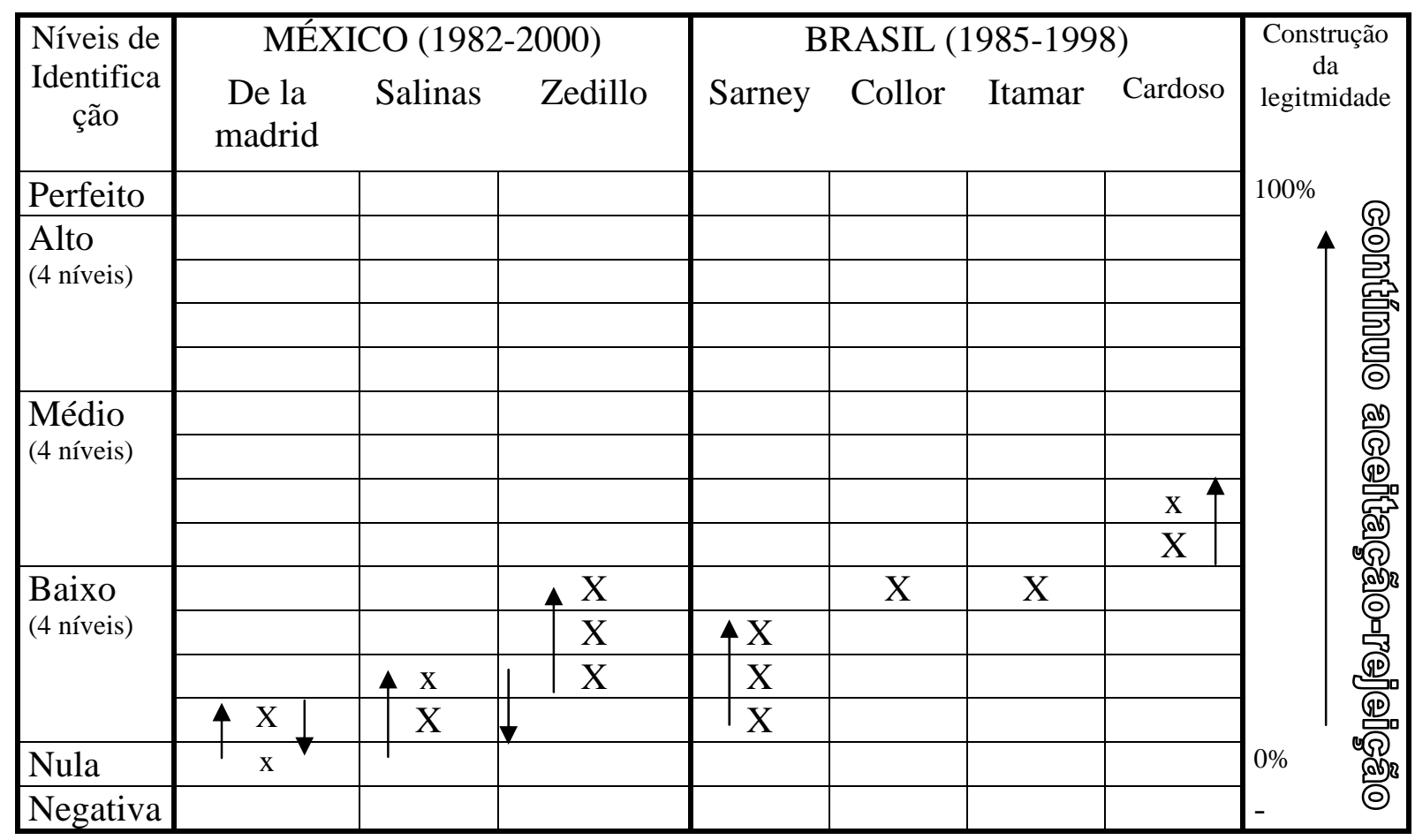

${ }^{142}$ Refiro-me aos requisitos de governança (internacional) da política econômica neoliberal, como controle e eficiência de gastos. Sobre o conceito de governança internacional e sua relação com a política econômica veja análise de Thomas J. Biersteker (2000) “O ‘triunfo’ da economia neoclássica no mundo em desenvolvimento: convergência de políticas e fundamentos da governança na ordem econômica internacional”, na bibliografia. Sobre a forma como o conceito se estende às demais políticas públicas, veja, de um lado, a análise crítica de Tuozzo (2004) e, de outro, a análise de Brinkerhoff (2000) em defesa do uso do conceito. 
Do ponto de vista comparativo, no entanto, distintos padrões de participação direta (Quadro 3.1) na decisão macro produziram diferentes níveis de identificação nas distintas etapas da reforma (Quadro 11.1). Isto quer dizer que a capacidade de influência da ortodoxia econômica na decisão foi correspondente aos padrões de participação direta (de PDD) na decisão, e estes padrões, por sua vez, produziram diferentes níveis de identificação no processo micro, no México e no Brasil, como vimos nas Partes I e II. Nestas, níveis de identificação foram interpretados como coeficientes de reciprocidade, logo, de legitimidade da política macro, na perspectiva micro-macro (Quadro 3.5) ${ }^{143}$.

No caso do México, lembremos que as diretrizes de descentralização (ou reforma nos anos de Salinas) foram re-elaboradas, a cada início de sexênio, pela nova elite priista e times de técnicos, sem a participação direta de movimentos contra-hegemônicos de saúde na decisão, e apenas com a influência indireta de mobilizações sociais. Este padrão restrito de participação direta na decisão redundou num processo de construção-desconstrução política do novo domínio público na saúde, uma vez que as políticas foram caracterizadas por um alto grau de conflitos e por um alto nível de descontinuidade. Ademais, mostrou-se mais acentuado, no padrão restrito de participação na decisão (de PDD) (Quadro 3.3), o grau de efeitos perversos produzidos na implementação, como demonstra os níveis baixos de identificação da política micro estadual com as estratégias de descentralização e reforma reivindicadas pela política macro nacional, em suas distintas fases políticas no México (Quadro 11.1). O aprendizado da elite priista e times de decisores em relação à viabilidade política da reforma mostrou-se extremamente lento. Lembremos que a estratégia de consulta a governadores foi adotada apenas no governo de Zedillo, doze anos após o início da reforma. Além disso, o ritmo perverso desse processo de construção política, na decisão, não favoreceu a construção de novas formas de socialização - condizentes com as diretrizes da reforma - nas instituições do sub-setor público-estatal da SSA ao longo da implementação, mas favoreceu a predominância das práticas políticas e administrativas de cunho patrimonialistas e das formas de socialização estado-cêntricas IMSSianas.

Já no Brasil, as recorrentes crises de governabilidade democrática, acirradas pela instabilidade econômica, não produziram uma interrupção drástica (ou desconstrução em termos nacionais) na reforma pública de saúde em construção desde os anos 70; uma vez que

\footnotetext{
${ }^{143}$ Veja marco analítico construído no Capítulo 3.
} 
as crises do SUS se confundiam menos com as crises de governabilidade da política macro como no México. O SUS foi construído mediante um padrão mais plural de participação política direta no processo político decisório macro, bem como resultou em níveis mais elevados de identificação, em comparação ao México. Uma vez que houve um maior crescimento no envolvimento do político e da sociedade no decorrer do processo político micro estadual e, sobretudo, municipal, apesar deste crescimento ainda ter se dado de forma contraditória aos valores e diretrizes do SUS, apresentando, por isto, um ritmo lento de construção do domínio público-estatal como reivindicado. Apesar da reforma brasileira ainda não ter logrado realizar na sua plenitude os valores e diretrizes constitucionais, apresenta-se como um processo cuja legitimidade tem sido paulatinamente construída; fato que tem garantido a continuidade do SUS em tempos de crise de governabilidade (Collor e Itamar) e de estabilização econômica (Cardoso) (Quadro 11.1).

Neste processo lento de construção da legitimidade de um novo domínio públicoestatal, as constrições políticas e administrativas do novo sistema de saúde - evidenciadas, por exemplo, na crise de financiamento, na baixa qualidade de atendimento do sistema hospitalar e no desenvolvimento de formas perversas de socialização herdadas do sistema INAMPSiano não impediram que houvesse o inicio da construção de formas novas e diversas de socialização na atenção médica no domínio público. Com o SUS os velhos interesses e práticas, institucionalizados e legitimados no decorrer de décadas no setor público-estatal de Saúde brasileiro, passaram a coexistir - de forma diversa e variada entre os municípios - com os novos interesses e práticas da medicina coletiva brasileira (ainda em lenta construção). À medida que o novo domínio público-estatal (o SUS) se expandiu para os vários municípios, o movimento sanitário ganhou um número incremental de adeptos políticos. As práticas representativas do modelo público-estatal INAMPsiano têm convivido com as novas práticas médicas e vínculos (formas de engajamento) de tipo “coletivo”, desenvolvidas de forma bem diversa nas redes de atenção básica de saúde (e em alguns hospitais), e sobretudo nos municípios de médio e de pequeno porte.

\section{Legitimidade e comprometimento político com a saúde da população aberta: a perspectiva macro-micro}

Se a legitimação mostra-se, de fato, como categoria analítica importante para se desvendar a dinâmica dos processos de descentralização e reforma de saúde para a população 
aberta na América Latina, e, mais especificamente, no México e no Brasil, seu uso remete-nos não apenas à análise dos processos (de decisão e implementação) das esferas micro como níveis distintos de identificação com a decisão macro, como também obriga-nos a efetuar o mesmo exercício analítico do ponto de vista da perspectiva macro-micro. Torna-se possível, neste sentido, desvendar a natureza dos valores/princípios ideológicos e interesses orientadores da decisão macro, bem como os níveis de comprometimento político da decisão macro, em cada fase política da reforma, verificando se e em que medida a decisão da política pública ocorreu em correspondência à realidade política e social da esfera micro, bem como em resposta às problemáticas evidenciadas no decorrer da implementação pretérita, ou se, de forma distinta, as decisões se deram de modo autoritário e autônoma da realidade política, administrativa e social vivida nas esferas políticas micro.

Encontra-se aqui a idéia de que o político (o ator político) deve dar conta de seus atos (decisões) à sociedade, em especial quando suas ações concretas mostram-se contraditórias às promessas de poder. O nível de comprometimento do ator político - com a política pública de saúde e com o público - enfocado revela-se de forma co-relacionada na forma como o político justifica e enfrenta as conseqüências de sua decisão e da dominação exercida. O ator político pode, num extremo, responsabilizar-se pelos resultados, comprometendo-se com seus atos e com a promessa que o legitima no poder, identificando-se com os valores e interesses da esfera micro e com os problemas ocorridos na implementação. Em outro extremo, o ator político pode resignar-se a assumir a responsabilidade pelas conseqüências de seus atos, recusando-se, a cada re-início de governo (bem como no decorrer do processo de decisão), a se comprometer com os resultados de seus próprios feitos ${ }^{144}$.

\footnotetext{
${ }^{144}$ Weber (1968b) constrói dois tipos analíticos que visam apontar características distintas da ação política, tanto no que se refere à sua orientação, quando ao seu conteúdo ético. Trata-se das condutas direcionadas por uma “ética de convicção" e por uma "ética de responsabilidade”. A “ética da convicção” corresponde a uma ética absoluta (de fins últimos), em que o fim da ação coincide com o meio da mesma. Por ser uma ação baseada em normas condicionadas pela fé (ou razão estremada, desmedida), o ator acredita que a ação resultará inevitavelmente na produção do bem, pois do bem só segue o bem. Já a "ética de responsabilidade”, por sua vez, considera todas as conseqüências previsíveis em decorrência da ação política. Esta ética exige rigor no cálculo da ação, seja no que tange aos meios (procurando adequá-los aos fins, minimizando os riscos e custos previstos), seja no que se refere às conseqüências desejáveis e não desejáveis possíveis de serem desencadeadas pela ação (decisão). A “ética da responsabilidade” se caracteriza, logo, pela exigência da previsão e pelo reconhecimento da autoria dos próprios atos. Os tipos-ideais teóricos ordenam conceitualmente ideais extremos de conduta, e, por isto, mostram-se como elementos analíticos ricos para se efetuar comparações entre ações políticas distintas verificadas na realidade. Nesta, se encontrarão sempre presentes os elementos característicos a cada uma dos dois tipos éticos. Ao utilizarmos os tipos ideais de Weber para comparar as ações políticas, torna-se possível apontar tanto as considerações responsáveis como os elementos de fé que nela misturam e se confundem na prática.
} 
Os processos decisórios macro das reformas públicas de saúde no México e no Brasil, no decorrer de duas décadas, certamente põem em foco as disjunções existentes entre a ordem legal que promete igualdade e integração social e a realidade das desigualdades e exclusões tramada na dinâmica das relações de poder e dominação, como vimos nesta tese (Partes II e III). Isto que dizer que as ações dos decisores macro (de modo geral) ainda "não corresponderam aos seus próprios feitos. Não corresponderam ${ }^{145}$ ao mundo como realmente $\underline{\text { é em sua rotina cotidiana }} \underline{146}$. Objetiva e realmente, não experimentaram a vocação para a política em seu sentido mais profundo, que julgavam ter” (Weber, 1979, p.152). Observe que aqui temos uma idéia potente para a compreensão da dificuldade de realização das diretrizes de política pública de saúde do ponto de vista da legitimidade. Trata-se da idéia de que é preciso ter uma correspondência (match) de valores e atitudes em ambos processos da política pública: macro e micro. A relevância atribuída por Max Weber ao requisito "correspondência (match) ao mundo como realmente é”, nos permite afirmar que quanto mais os valores/princípios ideológicos e diretrizes da decisão, no nível macro, coincidirem com os (corresponderem aos) das esferas políticas micro (em seus três sub-níveis), maior será a probabilidade de aceitação e de realização (de sucesso) da política reivindicada como legítima pelo poder. Neste sentido, o alvo da atuação política vocacionada só terá sido alcançado quando as legalidades construídas (no nível macro) produzirem um nível perfeito de identificação ${ }^{147}$ na implementação. Só aí teremos de fato a junção (união) das duas éticas, conviç̧ão e responsabilidade: que caracteriza de fato a ação política vocacionada. Só aí a ação política e, se recíproca ou em correspondência com a sociedade, produzirá a justiça social tão reivindicada e pouco “compreendida” sóciopolítica e culturalmente por teorias normativas da democracia.

Esta construção da legitimação de um novo domínio público de saúde ainda há que ser iniciada de forma mais definitiva no México (após 2000) e avançada no Brasil (a partir de 1998). Trata-se de construção orientada por modalidades distintas de tensões entre dois tipos estremados de normatividade: razão e paixão. Estas tensões devem, necessariamente, ser

\footnotetext{
${ }^{145}$ A edição inglesa traduzida do alemão (organizada por Peter Lassman e Ronald Speirs em 1994) utiliza o termo match, que ressalta a idéia de correspondência exata, de igualdade. Já na versão brasileira de Ensaios de Sociologia (Weber, 1979), traduzida da Edição inglesa de From Max Weber: Essays on Sociology (organizado por H.H. Gerth e C. Wright Mills, Oxford University Press, $1^{\text {a }}$ ed. 1946), e revista por Fernando Henrique Cardoso, temos o termo correspondência, como estou utilizando.

${ }^{146}$ Grifo meu.

${ }^{147}$ Quer dizer, quando a decisão política nacional coincidir com os valores e interesses que orientam a implementação.
} 
arbitradas pelo senso de justiça (ou de proporção entre razão e paixão) em relação às "exigências do momento"148. Nesta trajetória, as categorias "correspondência” (ou reciprocidade) e “identificação", pelo vínculo que se estabelece com “dominação" e "legitimação" "149, mostram-se como par conceitual para se compreender as relações entre decisão macro e processo político micro (decisão e implementação). Com efeito, tanto no México, quanto no Brasil, a reforma de saúde para a população não-assegura, ainda há que ser construída na tensão entre convicção e responsabilidade extremada, e será apenas na junção das duas éticas que a decisão política poderá, enfim, “experimentar a vocação política professada”.

Do ponto de vista comparativo, contudo, as distintas conexões entre padrões de participação direta (de PDD) e níveis de identificação e legitimidade revelam diferenciais de comprometimento da decisão política macro em relação à reforma da Saúde para a população aberta. Comparativamente, as constantes interrupções no processo de construção da política pública no México, de 1984 a 2000, nos levam a indagar se as decisões políticas do partido de Estado se deram de fato de forma compromissada com a população não-assegurada. Neste sentido, tendo em vista a predominância da ética de convicção sobre a de responsabilidade, não seria possível afirmar que as estratégias de reforma de saúde dirigida para a população não-assegurada e apresentadas à nação a cada início de sexênio teriam objetivado antes reanimar a promessa do poder do que realizá-la? Se avaliarmos a construção da reforma de saúde sob o ponto de vista da tensão entre as duas éticas, torna-se possível sugerir que o processo de decisão da política de saúde para a população nãoassegurada, no México, produziu um paradoxo ético de grau elevado: em que prevalece o compromisso com os fins em detrimento da responsabilidade (de meios); o que revela que o senso de justiça (proporção) não foi determinante na decisão. Tendo em vista o alto grau de efeitos perversos, vindos à tona ao fim de cada sexênio, e a forma como a política continuou sendo re-elaborada, a cada início de governo, propondo diretrizes altamente deslocadas da realidade política e social, logo, antagônicas às práticas institucionalizadas e reconhecidas como legítimas na política micro e sub-sistemas de saúde no decorrer da historia, a decisão política revelou ter um baixo nível de comprometimento com a saúde da população aberta.

\footnotetext{
${ }^{148} \mathrm{O}$ árbitro (inner balance) do senso de justiça (responsável) revela a autenticidade da paixão e da razão.

${ }^{149}$ Gabriel Cohn (1979) assinala a necessidade de se analisar a dominação e legitimação como par conceitual.
} 
Argumentamos que em contextos de extrema desigualdade social e em que padrões restritos de participação na decisão política têm caracterizado a atuação do Estado em relação à sociedade, a possibilidade de realização de uma decisão compromissada em relação à reforma da saúde deve ser caracterizada por uma construção política mais plural, na esfera política macro, e também implicar, ao mesmo tempo, um maior nível de identificação do político e do administrador público local com a proposta, bem como um maior nível de participação social durante a implementação, na esfera política micro.

No caso brasileiro, comparativamente ao mexicano, a associação do processo decisório do SUS (de 1985 a 1998) à níveis mais altos de identificação e de legitimidade nos leva a reconhecer que esta construção política em direção a um maior comprometimento com a Saúde só foi possível - na re-democratização e no decorrer da nova democracia - apesar de apresentar avanços de no processo de legitimação em relação ao caso mexicano, resultou num processo lento. Como vimos, ocorreu no Brasil um processo mais plural de luta entre valores e interesses de grupos inseridos na esfera macro, como representantes do movimento sanitário e os grupos que se opunham/opõem à democratização da atenção pública-estatal de saúde (como setor médico privado, seguridade social, economistas de governo e técnicos de políticas públicas). Além disso, uma construção social mesmo que ainda incipiente, concentrada em algumas cidades, e diversa nestas, precedeu à construção política da reforma na esfera política macro. Como já ressaltado, foi primeiramente junto a comunidades locais, por meio de diversas formas de interação social e, em seguida, mediante formas diversas de envolvimento do político e de administradores locais com a reforma da saúde, que se deu a trajetória deste movimento político no Brasil. No entanto, há que se ressaltar que a atuação apaixonada, muitas vezes extremada, do movimento sanitário brasileiro até então contribuiu tão-somente lentamente (e de modos distintos nos vários municípios e estados), desde meados/fim dos anos setenta, para a promoção dos valores e práticas de saúde pouco mais condizentes (e ainda contraditórios) com as diretrizes constitucionais do SUS. De forma semelhante, porém diversa do caso mexicano, a normatividae presente na concepção democrática ideológica da reforma brasileira não apresentava correspondência com a realidade política e social brasileira. Os valores e diretrizes da reforma, presentes nas novas legislações, embora menos antagônicos que na transição político-econômica mexicana, tiveram sua construção política caracterizada também em detrimento do sendo de proporção de justiça, o qual só pode ser atingido quando 
houver uma aproximação mais estreita entre responsabilidade e convicção. Isto é: na medida em que o processo democrático for caracterizado por uma construção mais correspondente entre processos macros e micros (ou macro, intermediários e micros), ou mais recíproca entre Estado e Sociedade.

\section{Brasil: caso paradigmático de reforma pública de saúde na América Latina}

Nosso argumento final é que a reforma de saúde brasileira mostra-se como um caso paradigmático no que se refere à possibilidade de construção de uma reforma pública de saúde com alta identificação e legitimidade na periferia do capitalismo e em tempo de novo liberalismo econômico. Isto quer dizer que o SUS revela-se como exemplo paradigmático dos avanços e das dificuldades relacionadas ao processo de mudança na percepção e atitude dos políticos, administradores e sociedade em geral em relação aos valores e diretrizes que orientam os processos de realização do direito à saúde.

O processo lento de construção da reforma brasileira nos permite apontar alguns prérequisitos para a construção de uma reforma pública de saúde com legitimidade crescente e lenta na periferia do capitalismo, e em tempo de dupla transição política. A reforma brasileira evidencia, primeiramente, que 1) a construção política deve ser mais plural e conflituosa. 2) Neste processo, a participação de novos atores políticos - com comprometimento com os valores e diretrizes da reforma - se mostra essencial para a continuidade do processo. 3) Além disso, estes atores devem não apenas possuir certo grau de autonomia em relação aos interesses inseridos na esfera política, como é preciso que defendam com mais responsabilidade (senso de proporção ou de justiça) a causa política. Esta dupla atitude os capacitará interiormente ${ }^{150}$ (e exteriormente) a enfrentar os interesses em jogo, bem como resultará na cooptação de novos atores à causa. Se isto ocorrer, inviabiliza-se politicamente a probabilidade de rompimento completo do consenso político em relação à reforma. 4) Há, no entanto, a possibilidade de rompimento com o compromisso de tipo constitucional. É preciso ainda ressaltar que 5) a continuidade da construção política mostra-se como possibilidade de lento desenvolvimento de formas menos patrimonialistas e

\footnotetext{
${ }^{150}$ Para Weber, a paixão é uma das qualidades essenciais do político, compreende a força interior que move a ação do político em direção a um ideal maior. Deve certamente ser guiada com capacidade de responsabilização, isto é: sinceridade entre atos e palavras. É como se as qualidades requeridas do político só fosse possível na junção das duas éticas máximas.
} 
objetivamente mais racionais de participação no domínio público-estatal. As análises realizadas em municípios pequenos e médios (Capistrano Filho, 1999) (Silva, 2001) (Pinheiros e Mattos, 2001 e 2003), (Goulart, 2002) no Brasil demonstram que estas mudanças só acontecem quando se verificam níveis mais altos de comprometimento do político local, de engajamento/vínculo da administração pública (funcionários, médicos e enfermeiros) e de participação e envolvimento da sociedade no processo político concernente à política pública de saúde.

Na política, o processo de conversão dos valores em atitudes não se traduz em “alternação" como ocorre nas religiões, e anseia a teoria da administração pública e a economia. Esse processo possui uma associação mais estreita com os de “socialização”, por se tratarem de "processos de mudanças em que se conserva muito do velho”. Na esfera política, distintamente da religiosa, a conversão social tende a ser extremamente lenta. A alternação idealizada e legalizada apresenta-se menos lenta quando a decisão política se dá de forma mais comprometida com as "exigências do momento". Mostra-se essencial, assim, considerar o modo como os principais atores são envolvidos no processo da política pública, na decisão e implementação. Uma construção política comprometida, por possibilitar o desenvolvimento de níveis maiores de identificação, levando os atores da esfera micro a reverem suas percepções e atitudes em relação ao significado do domínio público, mostra-se mais capaz de viabilizar a construção de uma nova legitimidade para a política pública. Esta viabilização, portanto, requer não apenas técnica (Bossert \& Rosseti, 1999) - que viabilize mormente uma "racionalização via fins” das “exigências do momento” - , mas também um comprometimento político “autêntico”. É esta conciliação da técnica (e/ou paixão) com o senso de justiça (ou de proporção) que possibilitará a construção de políticas públicas mais legítimas.

Em sociedades como as da América Latina, submetidas a um ciclo de crises de governabilidade no decorrer do tempo, associado não apenas às mudanças de regime político e de modelo econômico, mas em especial ao tipo de relacionamento existente entre Estado e Sociedade, a construção de uma nova política pública corresponde a um problema conjuntural e estrutural. Torna-se relevante, assim, estudar o processo político da reforma de saúde, para a população aberta, no Brasil e México, bem como em outros países da América Latina e de forma comparada, como um processo de legitimação, o qual requer não apenas a construção político-institucional de bases de legalidade (leis constitucionais, regulamentações e 
programas), como também uma nova construção social, isto é: mudança nos valores e atitudes por parte daqueles que participam do processo da política pública de saúde.

Neste sentido, sugerimos que o recente processo de extensão do acesso às políticas de atenção à saúde para a população aberta, na América Latina, e à luz do caso brasileiro, sejam investigados e compreendidos mais além dos pré-requisitos de consolidação democrática vinculados ao processo de democratização das velhas democracias sociais, bem como de conceitos "burgueses” como cidadania e espaço público - e mais além da perspectiva e uso de conceitos institucionalistas tão-somente, que sobre-enfatizam a questão da eficiência na distribuição e gasto de recursos. O uso destes conceitos, se utilizados, deve-se dar de forma crítica e estruturada num marco de análise mais compreensivo como o das relações Estado/Sociedade. Requer-se também o desenvolvimento de análises exploratórias diferencias que levem em consideração as articulações existentes entre o nível macro e micro da política, e suas articulações com a esfera social e econômica.

(...) "agiremos (então) de modo diferente. Procuraremos trabalhar e atender às 'exigências do momento', nas relações humanas e em nossa vocação. Isto, porém, é claro e simples, se cada um de nós encontrar e obedecer ao demônio que controla os cordões de nossa própria vida” (Ciência como vocação, Max Weber, 1979, p.183). 


\section{Referências: entrevistas e bibliografia}

\section{Entrevistas no México}

ABRANTES, Raquel P. Pesquisadora do Instituto Nacional Salud Pública (INSP) do México. Cuernavaca, México, Fevereiro de 2001 e Março de 2003.

ARJONILLA ALDAY, Sofia. Pesquisadora do Instituto Nacional Salud Pública (INSP) do México. Cuernavaca, México, Fevereiro de 2001.

CABRERO, Enrique M. Pesquisador do Centro de Investigación y Docencia Económica (CIDE), México. Cidade do México, Fevereiro de 2001.

DURAN, Luis. Diretor do Departamento de Projetos do IMSS. IMSS, Cidade do México, Março de 2003.

LAURELL, Asa Cristina. Secretária de Saúde do Governo do Distrito Federal, Mestrado em Medicina Social da Universidad Autónoma Metropolitana - Xochimilco. Cidade do México, Março de 2003.

LEAL, Gustavo F. Departamento de Ciências Biológicas e da Saúde (CBC) da Universidad Autónoma Metropolitana - Xochimilco. Cidade do México, Março de 2003.

LÓPEZ-ARELLANO, Oliva. Mestrado em Medicina Social da Universidade Autônoma Metropolitana - Xochimilco. Foi Diretora de Planejamento e Coordenação Setorial da Secretaria de Saúde do Governo do Distrito Federal, México. Cidade do México, Março de 2003.

MALDONADO, Alberto H Assessor da Secretaria Estadual de Saúde do Estado de Colima. Cuernavaca, México, Março de 2003.

MOLINA, Juan Francisco R. Departamento de Políticas e Serviços de Saúde do Instituto Nacional de Saúde Pública, Cuernavaca, México. Por vinte anos foi assessor da Secretaria Estadual de Saúde do estado de Morelos. Cuernavaca, México, Março de 2003.

NIGENDA, Gustavo. Diretor do Centro de Investigaciones en Salud da Fundação Mexicana para Saúde (FUNSALUD). Cidade do México, Fevereiro de 2001 e Março de 2003.

OLVERA, Lucila S. Assessora da Secretaria Estadual de Saúde do Estado de Baja California Sur. Entrevista em Cuernavaca, México, Março de 2003.

PAREDES RANGEL, Beatriz.3). Deputada da República Mexicana. Foi Gobernadora Constitucional del Estado de Tlaxcala (Enero/1987 - Marzo/1992). Senadora de la República LVII Legislatura, (01/Nov/97 - 31/Ago/2000). Entrevista na Câmara de Deputados, Cidade do México, Março de 2003.

PÉREZ CUEVAS, Ricardo (2003) Assessor da Diretoria de Prestações Médicas do IMSS. Entrevista no IMSS, Cidade do México, Março de 2003. 
SOBERÓN-ACEVEDO, Guillermo (2003). Diretor-presidente da Fundação Mexicana para Saúde (FUNSALUD). Foi Ministro da Saúde no sexênio de De la Madrid. Entrevista na FUNSALUD, Cidade do México, Março de 2003.

ULLOA PADILLA, Odilia (2003) Assessora da Comissão de Seguridade Social da Câmara de Deputados, Cidade do México, México. (Comissão presidida pelo PRD). Entrevista na Câmara de Deputados, Março de 2003.

\section{Entrevistas no Brasil}

CARVALHO, Gilson (2003) - CONASEMS (Conselho Nacional de Secretários Municipais de Saúde). Foi Secretário de Saúde do Município de São José dos Campos. Entrevista por e-mail em duas ocasiões entre agosto e setembro (18) de 2003.

ELIAS, Paulo E M (2003) Departamento de Medicina Preventiva, Faculdade de Medicina da USP, CEDEC. Entrevista em 16 de agosto de 2003, no CEDEC, São Paulo.

ESCOREL, Sarah (2003) Centro Brasileiro de Estudos da Saúde (CEBES), ENSP/Fiocruz. Entrevista em 19 de setembro de 2003, na FIOCRUZ, Rio de Janeiro.

HEIMANN, Luiza (2003) Instituto de Saúde da Secretaria Estadual de Saúde de São Paulo. Em 08 de setembro de 2003, no Instituto de Saúde, São Paulo.

LAVRAS, Carmem Cecília de Campos (2003) Pró-Reitora de Extensão e Assuntos Comunitários da PUC Campinas. Médica sanitarista, foi Secretária de Saúde do Município de Campinas. Entrevista em 26 de agosto de 2003, na PUCCAMP, Campinas.

MENDES, Áquilas (2003) Pesquisador do CEPAM/USP. Foi assessor de Eduardo Jorge na Secretaria Municipal de Saúde em São Paulo. Entrevista em 12 de agosto de 2003, no CEPAM/USP, São Paulo.

MERHY, Emerson Elias (2003) Departamento de Medicina Preventiva e Social da Faculdade de Ciências Médicas Unicamp. Entrevista realizada em Campinas dia 03 de setembro de 2003.

MOSCONI, Carlos Eduardo Venturelli (2003) Presidente da FHEMIG. Médico, Professor Universitário e Presidente do PSDB de Minas gerais. Deputado Federal nas Legislaturas: 1983-1987; 1987-1991; 1995-1999 e 1999-2003. Foi Deputado Federal Constituinte (1987-1991). Presidente do INAMPS (1992-1993) Entrevista realizada em Belo Horizonte em 30 de setembro de 2003.

ONOKO, Rosana (2003) Departamento de Medicina Preventiva e Social da Faculdade de Ciências Médicas da Unicamp. Entrevista em 09 de setembro de 2003, na FCM/UNICAMP, Campinas. Em 09 de setembro de 2003.

PINHEIRO, Roseni (2003) Instituto de Medicina Social da UERJ. Entrevista em 27 de agosto no IMS/UERJ, Rio de Janeiro.

SILVA, José Carlos (2003) Secretaria Municipal de Saúde de Campinas (Secretaria de Gestão). Entrevista em Campinas dia 03 de setembro de 2003. 


\section{Documentos oficiais}

CÁMARA DE DIPUTADOS. Constitución Política de los Estados Unidos Mexicanos (com atualizações de 1917). Ciudad de México: 2004, 117p. Disponível em: http://www.cddhcu.gob.mx/leyinfo/pdf/1.pdf . Acesso em: 13 julho 2004.

IBGE. Anuário Estatístico de Saúde do Brasil 2001. Brasília: IBGE e Ministério da Saúde. Disponível em: http://portal.saude.gov.br/saude/aplicacoes/anuario2001/index.cfm . Acesso em: 10 abril a julho 2004.

IBGE. Estatísticas de Saúde In: Estatísticas do Século XX, Rio de Janeiro: IBGE. Disponível em: http://www.ibge.gov.br/seculoxx/default.shtm . Acesso em: 12 dez. 2003.

MÉXICO, Constitución Política de los Estados Unidos Mexicanos de 1917. Disponível em: http://www.georgetown.edu/pdba/Constitutions/Mexico/mexico1917.html . Acesso em: 13 julho 2004.

MINISTÉRIO DA SAÚDE. Instrução Normativa $\mathbf{N}^{\mathbf{0}}$ 01/98. Brasília: MS, 1998, 41p. Disponível em: http://portal.saude.gov.br/saude/arquivos/pdf/in98.pdf . Acesso em 23 abr. 2004.

MINISTÉRIO DA SAÚDE. Lei $\mathbf{N}^{\mathbf{0}}$ 8.080. Brasília: MS, 1990, 19 p. Disponívem em: http://portal.saude.gov.br/saude/arquivos/pdf/lei8080.pdf . Acesso em 23 abr. 2004.

MINISTÉRIO DA SAÚDE. Lei Nº 8.142. Brasilia: Ministério da Saúde do Brasil, 1990, 03 p. http://portal.saude.gov.br/saude/arquivos/pdf/lei8142.pdf . Acesso em 23 abr. 2004.

MINISTÉRIO DA SAÚDE. Norma Operacional Básica do Sistema Único de Saúde/NOBSUS 96. Brasília: Ministério da Saúde do Brasil, 1997, 34 p.

PODER EJECUTIVO FEDERAL, ESTADOS UNIDOS MEXICANOS Plan Nacional de Desarrollo (1983-1988). México: PODER EJECUTIVO FEDERAL, 1995, p.177.

PODER EJECUTIVO FEDERAL, ESTADOS UNIDOS MEXICANOS Plan Nacional de Desarrollo, Informe de Ejecución 1995. México: Secretaría de Hacienda y Crédito Público, 1995: p. 511.

PODER EJECUTIVO FEDERAL, ESTADOS UNIDOS MEXICANOS. Plan Nacional de Desarrollo (1983-1988). México: Secretaría de Programación y Presupuestos, 1983, 422 p.

PODER EJECUTIVO FEDERAL, ESTADOS UNIDOS MEXICANOS. Programa de Reforma del Sector Salud 1995-2000. México: Secretaría de Gobernación, 1995, p.84.

PODER EJECUTIVO FEDERAL, ESTADOS UNIDOS MEXICANOS. Programa Nacional de Salud 1984-1988. México: Secretaría de Salud, 1984, p.309.

PODER EJECUTIVO FEDERAL, ESTADOS UNIDOS MEXICANOS. Programa para un Nuevo Federalismo 1995-200. México: Secretaría de Gobernación, 1997, p.81.

SECRETARIA DE SALUD (SSA), ESTADOS UNIDOS MEXICANOS. Informes de Labores (1995-1996). México, DF. Secretaria de Salud, 1996, p.131. 
SECRETARIA DE SALUD (SSA), ESTADOS UNIDOS MEXICANOS. Informes de Labores (1997-1998). México, DF. Secretaria de Salud, 1998, p.177.

SECRETARIA DE SALUD (SSA), ESTADOS UNIDOS MEXICANOS. Informes de Labores (1998-1999). México, DF. Secretaria de Salud, 1999: 191.

SECRETARIA DE SALUD (SSA), ESTADOS UNIDOS MEXICANOS. Informes de Labores (1999-2000). México: Secretaria de Salud, 2000, 206 p..

SECRETARIA DE SALUD (SSA), ESTADOS UNIDOS MEXICANOS. Programa Nacional de Salud (1990-1994). México: Secretaría de Salud, 1990, 78 p.

SECRETARIA DE SALUD, ESTADOS UNIDOS MEXICANOS (SSA) ENCUESTA NACIONAL DE SALUD II (ENSA II). México: Secretaria de Salud, 1994, 83 p.

SECRETARIA DE SALUD, ESTADOS UNIDOS MEXICANOS Síntesis Ejecutiva: Gasto Público en Salud 1999-2000. México: Secretaría de Salud, Coordinación General de Planeación Estratégica, 2003, 15 p.

SECRETARIA DE SALUD, ESTADOS UNIDOS MEXICANOS, Ley General de Salud, In: http://www.salud.gob.mx/unidades/dgaj/ acesso em 05 de maio de 2004.

SENADO FEDERAL. Constituição da República Federativa do Brasil 1988. Brasília: Senado Federal da República do Brasil, 1988, 221 páginas. http://www.senado.gov.br/bdtextual/const88/const88.htm

\section{Livros e artigos}

ABRANCHES, Sérgio, Política Social e combate à pobreza: a teoria da prática.. In: ABRANCHES, S; SANTOS, W. G. \& COIMBRA, M. Política social e combate à pobreza. Rio de Janeiro: Zahar Editores, p. 9-30, 1987.

ABRANTES, R P.; ARJONILLA ALDAY, S. Descentralización del sector de salud y conflictos con el gremio médico en México. Revista de Saúde Pública, São Paulo, 36(3), p. 324-329, 2002.

ABRANTES, R. P.; ALMEIDA, C. Teoria y prática de las reformas en los sistemas de salud: los casos de Brasil e México. Cadernos de Saúde Pública, Rio de Janeiro, 18(4), p. 971-989, jul./ago, 2002.

ABRANTES, Raquel P. La reforma de los servicios de salud en México y la dinamización de los intereses: una aproximación. História, Ciências e Saúde, Vol. IV (2), p. 245-263, Jul-Out., 1997.

ABRUCIO, Fernando Luiz. Os Barões da Federação: os governadores e a redemocratização brasileira. São Paulo: Hucitec, 1998, 253 p.

ACUÑA, Carlos H. \& SMITH, William C. The Political Economy of Structural Adjustment: the logic of support and opposition to neoliberal reform. In SMITH, W; ACUNA, C \& GAMARRA, E. (Eds.) Latin American Political Economy in the Age of Neoliberal 
Reform: Theoretical and Comparative Perspectives for the 1990s. Miami: North South Center - University of Miami, 1994, p. 17-63.

AGUIRRE, Basilia e SADDI, Fabiana C. Fantasia política ou política da fantasia?. Revista de Economia Política, vol. 18 , no 2 (70), p.145-147, abril-junho, 1998.

AGUIRRE, Basilia e SADDI, Fabiana C. Uma Alternativa de Interpretação do II PND. Revista de Economia Política, vol. 17 , no 4 (68 ), p.78-98, out-dezembro, 1997.

ALLEYNE, George A. O. A vision for health system reform in Latin America”. Revista Pan Americana de Salud Pública, 8(1/2), p. 1-6 p, 2000.

ALMEIDA, M. et al.. O Município e as AIS no Paraná. Saúde em Debate - CEBES, Rio de Janeiro, p. 18-24, jun. 1988.

ALMEIDA, M. J. ; CORDONI JR, L. Um passo adiante?!. Saúde em Debate - CEBES, Rio de Janeiro, n. 10, p. 11-26, 1980.

ALMEIDA, Maria Hermínia Tavares. Federalismo e políticas Sociais. São Paulo: Revista Brasileira de Ciências Sociais, n. 28, p. 88-108, 1995.

ARELLANO GAULT, David. Mexican public sector reform: patrimonialist values and governmental organisational culture in Mexico. Documentos de Trabajo CIDE n. 82, Division de Administración Pública. México: CIDE, 2000, 17 p.

AROUCA, Sérgio. Implementação da reforma sanitária através do SUDS. Saúde em Debate CEBES, Rio de Janeiro, p. 49-54, out. 1988.

AROUCA, Sérgio. Reforma Sanitária não se resumiu à criação do SUS. Entrevista realizada pela Revista RADIS, Grupo Interinstitucional de Comunicação e Educação em Saúde de Santa Catarina, In http://www.grupogices.hpg.ig.com.br/Arouca.html , 14 p, 2003.

ARRETCHE, Marta; RODRIGUEZ, Vicente. Descentralizar e universalizar a atenção à saúde. In ARRETCHE, Marta; RODRIGUEZ, Vicente orgs. Descentralização das Políticas Sociais no Brasil. São Paulo: Edições Fundap, 1999, p. 126-158.

ASHA, George. Accountability in Health Services: transforming relationship and contexts. Working Paper Series Harvard Center for Population and Development Studies, volume 13 N. 1. Cambridge: Harvard Center for Population and Development Studies, 2003, $16 \mathrm{f}$.

ATKINSON, S; Medeiros, Oliveira \& Almeida. Going down to the local: incorporating social organization and the political culture into assessments of decentralized health care. Social Science and Medicine 51, p. 619-636, 2000.

ATWOOD, Angela. Health Policy in Brazil: The State's Response to Crisis. In GRAHAM, Lawrance S. \& WILSON, Robert H. The Political Economy of Brazil. Austin: University of Texas Press, 1990, p. 141-286.

BACHA, Edmar. Plano Real: uma segunda avaliação. In IPEA, Plano Real e outras experiências internacionais de estabilização. Brasília: IOPEA/CEPAL, 1997, p. 177204.

BARAJAS, Gabriela. Las políticas de administración de la pobreza en México: ayer y hoy. Foro Internacional, Cidade do México, v. 42, n. 1, p. 63-98, jan./mar. 2002. 
BASÁÑEZ, Miguel. La lucha por la hegemonía en México 1968-1990. México: Siglo XXI, 1990. 309 p.

BELMARTINO, Susana. Los valores vinculados a equidad en la Reforma de la atencion en Argentina. Cadernos de Saúde Pública. Rio de Janeiro: 18(4), p. 1067-1076, 2002.

BERGER, Peter L.; LUCKMANN, Thomas. A construção social da realidade. Petropólis: Editora Vozes, 2003. 248 p.

BERLINGUER, G. Globalização e a saúde global. Revista Estudos Avançados - Dossiê Saúde Pública, São Paulo, v.13, n. 35, p. 21-38, jan./abr. 1999.

BERTOLLI FILHO, Cláudio. História da Saúde Pública no Brasil. São Paulo: Editora Ática, 2001, $71 \mathrm{p}$.

BEYER, J.; PREKER, A.; FEACHEM, R. The role of the World Bank in International Health: renewed commitment and partnership. Social Science \& Medicine, n. 50, p. 169-176, 2000.

BIERSTEKER, Thomas J. O 'triunfo' da economia neoclássica no mundo em desenvolvimento: convergência de políticas e fundamentos da governança na nova ordem econômica internacional. In ROSENAU, James and CZEMPIEL, Ernst-Otto (Ed.) Governança sem governo: ordem e transformação na política mundial. Brasília: Editora UNB, 2000, p. 143-182.

BODESTEIN, Regina. Atenção Básica na agenda da saúde. Ciência \& Saúde Coletiva, 7(3), p. 401-412, 2002.

BONILLA CASTAÑEDA, Javier. Descentralización de la Secretaría de Salud. SECRATARIA DE SALUD. Hacia la federalización de la salud en México. México: Consejo Nacional de Salud, 1996, p.64-74.

BOSSERT, Thomas J \& GONZALEZ ROSSETTI, A . Comparative analysis of policy processes: enhancing the political feasibility of health reform. Boston: Harvard School of Public Health / Health Sector Reform Initiative, 1999, 32 f.

BOSSERT, Thomas J. Decentralization. In JANOVSKY, Katja ed. Health policy and system development: an agenda for research. Geneva: World Health Organization. 1996, p. 147-160.

BOSSERT, Thomas. La descentralización de los sistemas de salud en Latinoamérica: un análisis comparativo de Chile, Colombia y Bolivia. Boston: Harvard School of Public Health / Health Sector Reform Initiative, 2000, 35 f.

BOURDIEU, Pierre. Contrafogos: táticas para enfrentar a invasão neoliberal. Rio de Janeiro: Jorge Zahar Ed., 2001. 115 p.

BOYER, Robert. Estado e mercado: um novo envolvimento no século XXI?. In BOYER, R e DRACHE, Daniel Estados contra mercados: os limites da globalização. Lisboa, Instituto Piaget, 105-137 p.

BRACHET-MÁRQUEZ, V. Explaining Social political Change in Latin America: The case of Mexico. Latin American Research Review, 27/3, pp. 91-122, 1992.

BRACHET-MÁRQUEZ, Viviane. El pacto de dominación: Estado, clase y reforma social en México (1910-1995). México: El Colégio de México, 2001. 317 p. 
BRANCO, Marta de Castello. Brasil e México: duas experiências de ajuste estrutural. Rio de Janeiro: IPEA, 1993. 231 p.

BRONFMAN, Mario. Hacemos lo que podemos: los prestadores de servicios frente al problema de la utilización. Salud Pública de México, vol.39, n.6, nov./dez. 1997. Impressão da versão eletrônica, formato html, $10 \mathrm{p}$. Disponível em http://www.insp.mx/salud/39/396-7.html . Acesso em: 02 mai. 2003.

BURGESS, M. e GAGNON, A. Comparative Federalism and Federation: Competing Traditions and Future Directions. Toronto, University of Toronto Press, 1993.

CABRERO, Enrique M \& MEJÍA, José L. El estudio de las políticas descentralizadoras en México. Un reto metodológico. In CABRERO, Enrique M (coord..) Las Políticas Descentralizadoras en México (1983-1993). Logros y Desencantos. Ciudad de México, Miguel Ángel Porrúa/CIDE, 1998, p. 55-100.

CABRERO, Enrique; CARRERA, Ady. Fiscal Decentralization and institutional constraints. Paradoxes of the Mexican case. Documento de Trabajo CIDE n. 85. División de Administración Pública. 44 p., 2000.

CAETANO, Rosangela \& DAIN, Sulamis. O Programa Saúde da Família e a Reestruturação da Atenção Básica à saúde nos Grandes centros Urbanos: velhos problemas, novos desafios, PHYSIS: Revista de Saúde Coletiva, volume 12, número 1, p. 11-22, 2002.

CAMPOS, F. E. O Desafio da Expansão do Programa Saúde da Família nas Grandes capitais Brasileiras”, PHYSIS: Revista de Saúde Coletiva, v. 12, n. 1, p.47-58, 2002.

CAMPOS, G. W. S. Um balanço do processo de municipalização dos serviços de saúde no Brasil. Saúde em Debate, Rio de Janeiro, (28), p.24-27, mar. 1990.

CANSINO, César. La Transición Mexicana (1977-2000). México: Colección Estudios Comparados 5, CEPECOM (Centro de Estudios de Política Comparada), 2000. 368 p.

CAPISTRANO FILHO, D. ; PIMENTA, A. L. Bauru: a experiência que deu certo. Saúde em Debate - CEBES, Rio de Janeiro, p. 25-28, jun. 1988.

CAPISTRANO FILHO, David. O programa de saúde da família em São Paulo. Revista Estudos Avançados - Dossiê Saúde Pública, São Paulo, v.13, n. 35, p. 89-100, jan./abr. 1999

CAPISTRANO FILHO, David. Das duas cidades. São Paulo: Hucitec, 1995, 154p.

CARDONA, V. A 19 años de descentralización, fracasan la "planeación estratégica” y el "papel rector” de la Secretaría de Salud. Imagen Médica. México. Disponível em: http://www.imagenmedica.com.mx/reportagosto2003/impression/falta.htm . Acesso em: 13 nov. 2003.

CARDOSO, Fernando H \& FALETO, Enzo. Dependencia y Desarrollo en America Latina. México: Siglo XXI Editores, 1999. 213 p.

CARNEIRO, R. Globalização financeira e inserção periférica. Economia e Sociedade, Campinas, (13):57-92, dez. 1999.

CARVALHO, Gilson de C. Marques de. O Financiamento público federal do Sistema Único de Saúde. 2002. 370 f. Tese (Doutorado em Saúde Pública) - Faculdade de Saúde Pública, Universidade de São Paulo, São Paulo, 2002. 
CARVALHO, Gilson. A inconstitucional administração pós-constitucional do SUS através de normas operacionais. Ciência e Saúde Coletiva - A política de Saúde no Brasil nos anos 90, Rio de Janeiro, v. 6, n. 2, p. 435-444, 2001.

CASAR, Maria Amparo. Las bases político-institucionales del poder presidencial em México. In MAYER-SERRA, Carlos Elizondo, NACIF HERNANDEZ, Benito comp. Lecturas sobre el cambio político en México. México: FCE, 2002, p. 41-78.

CASTRO, R. Ciencias sociales y salud en México: movimentos fundacionales y desarrollos actuale. Ciência e Saúde Coletiva - ABRASCO, Rio de Janeiro, v. 8, n. 1, p. 47-62 2003.

CAVAROZZI, Marcelo. México: Pasado e presente de su fórmula política. In MIDDLEBROOK, $\mathrm{K}$ \& MOLINAR, $\mathrm{J} \mathrm{H}$ (Eds.) Las dimensiones políticas de la reestructuración económica. México, Cal y Arena, 1996, p. 463-490.

CAVAROZZI, Marcelo. Politics: A Key for the long term in South America. In SMITH, W; ACUNA, C \& GAMARRA, E. (Eds.) Latin American Political Economy in the Age of Neoliberal Reform: Theoretical and Comparative Perspectives for the 1990s. Miami: North South Center - University of Miami, 1994, p. 127-155.

CEBES .VII Conferência Nacional de Saúde: O PREVSAÚDE em Debate. Saúde em Debate, São Paulo, n. 10, pp.23-26, 1980.

CERCONE, James; DE ST. ANTOINE, Jean-Jaques. Reform of the Mexican Healthcare system. GIUGALE, Marcelo; LAFOURCADE, Olivier; NGUYEN, Vinh H. (Eds.) Mexico: a comprehensive development for the new era. The World Bank, 2000, p. 409-446.

COHN, Amélia. A Política Social no Governo FHC. Tempo Social, v. 11, n. 2, p.183-198, out. 1999.

COHN, Amélia. A Saúde na Previdência Social e na Seguridade Social: Antigos Estigmas e Novos Desafios. In COHN, Amélia e ELIAS, Eduardo Paulo. Saúde no Brasil: Políticas e Organização de Serviços. São Paulo: Editora Cortez., 1999, p. 13-58.

COHN, Amélia. Conhecimento e prática em saúde coletiva: o desafio permanente. Saúde e Sociedade, São Paulo, v. 1, n. 2, p. 97-110, 1992.

COHN, Amélia. O Sistema Único de Saúde: a síndrome da dualidade. Revista USP - Dossiê Saúde, São Paulo, p. 5-15, 2001.

COHN, Amélia. Previdência Social e Processo Político no Brasil. São Paulo: Editora Moderna, 1980. 237 p.

COHN, Gabriel. Crítica e Resignação: Fundamentos da Sociologia de Max Weber. T. A. São Paulo: Queiroz Editor, 1979. 161 p.

COHN, Gabriel. Introdução. In WEBER, Max. Parlamento e Governo na Alemanha Reordenada: Crítica Política do Funcionalismo e da Natureza dos Partidos. Petrópolis: Editora Vozes, 1993, p. 7-22.

COICAUD, Jean-Marc. Legitimacy and Politics: A contribution to the Study of Political Right and Political Responsibility. Cambridge: Cambridge University Press, 2003. 258 p. 
COLLINS, Charles. Decentralization. In JANOVSKY, Katja ed. Health policy and system development: an agenda for research. Geneva: World Health Organization, 1996, p. 161-178.

COLLINS, Charles; ARAÚJO, José. \& BARBOSA, Jarbas. Decentralizing the health sector: issues in Brazil. Health Policy, 52, p. 113-127, 2000.

CORCUFF, Philippe. As Novas Sociologias: construções da realidade social. Bauru: EDUSC. $206 \mathrm{p}$.

CORDEIRO, Hésio. As Empresas Médicas: as transformações capitalistas da prática médica. Rio de Janeiro: Edições Graal, 1984. 175 p.

CORDEIRO, Hésio. Descentralização, universalização e equidade nas reformas de saúde. Ciência e Saúde Coletiva, Rio de Janeiro, v. 6, n. 2, p. 319-327, 2001.

CORDEIRO, Hésio. Empresas Médicas. Saúde em Debate - CEBES, Rio de Janeiro, n. 13, p. 22-31, 1981.

CORDEIRO, Hésio. INAMPS: dois passos adiante e um para trás (Hésio Cordeiro, em entrevista concedida a Marcus Barros Pinto). Saúde em Debate - CEBES, Rio de Janeiro, p. 36-38, jun. 1988.

CORDERA CAMPOS, Rolando Cordera; SÁNCHEZ REBOLLEDO, Adolfo Sánchez. Los ritmos de la democracia y la economía política del presidencialismo. In SALASAR, Luis C. México 2000: alternacia y transición a la democracia. México: Cal y Arena, 2001, p. 455-490.

CORNELIUS, Wayne A .The political economy of Mexico under de La Madrid: the crisis deepens, 1985-1986. San Diego: Center for US-Mexican Studies, Research Report Series, 43, 1986. 49p.

CORTES, S. M. V. Construindo a possibilidade da participação dos usuários: conselhos e conferências no Sistema Único de Saúde. Sociologias, Porto Alegre, v. 4, n. 7, p. 18-49, jan./jun. 2002.

COSTA, Nilson do Rosário. Lutas urbanas e controle sanitário: origens da política de saúde no Brasil. Petrópolis: Editora Vozes, 1986. 128 p.

COULSON, Margaret A .; RIDDEL, David S. Introdução crítica à Sociologia. Rio de Janeiro: 1975. 143 p.

CRUZ, A . Terminará desabasto fármacos este año: SSA. La Jornada. In: http://www.jornada.unam.mx/2003/feb03/030226/048n2soc.php?origem=soc-jus.htm Acesso em: 13/nov./2003

DIMENSTEIN, Gilberto; SOUZA, Josias. A História Real: trama de uma sucessão. São Paulo: Editora Ática, 1994, 242 p.

DOS SANTOS, Nelson Rodriguez. Contribuição ao entendimento do novo médico geral ou de família. Saúde em Debate - CEBES, Rio de Janeiro, v. 7, n. 8, p. 39-43, 1978.

DOS SANTOS, Nelson Rodriguez. O Modelo SUS: Bases conceituais e de Estratégias de Construção. Campinas: mimeo, 7 f. 
DOS SANTOS, Nelson Rodriguez. Prestação de contas na gestão da saúde em Campinas. Saúde em Debate - CEBES, Rio de Janeiro, p. 07-09, jun. 1988.

DRAIBE, Sônia Miriam. Repensando a política Social: dos anos 80 ao início dos 90 In: SOLA, Lourdes e PAULANI, Leda M. (Ed.) Lições da Década de 80, São Paulo, Edusp, 1995, p. 201-224.

DRESSER, Denise. Bringing the Poor In: CORNELIUS , Wayne A.; CRAIG, Ann L.; FOX , Jonathan (Ed.). Transforming State-Society Relations in Mexico: the National Solidarity strategy. USA, San Diego: Center for U.S.-Mexican Studies - UCLA, 1994, cap. 8, p.143-165.

ELAZAR, D. Tendências Centralizadoras e descentralizadoras dos sistemas federativos contemporâneos: uma análise preliminar. Revista de Administração Municipal. 28 (159), abr./jun. 1981.

ELAZAR, Daniel. Exploring Federalism. Tuscaloosa: University of Alabama Press, 1987. 335 p.

ELIAS, P. E. ; MARQUES, R. M. ; MENDES, A. O financiamento e a política de saúde. Revista USP - Dossiê Saúde, São Paulo, p.16-27, set/out/nov 2001.

ELIAS, Paulo Elias. PAS: um perfil neoliberal de gestão de sistema público de saúde. Revista Estudos Avançados - Dossiê Saúde Pública, São Paulo, v.13, n. 35, p. 125-140, jan./abr. 1999.

ELIAS, Paulo Elias. Por uma refundação macropolítica do SUS: a gestão para a eqüidade no cotidiano dos serviços. Saúde e Sociedade, São Paulo, v.11, n. 1, p. 25-36, jan/jul. 2002

ESCANDÓN, P. La provisión de medicamentos. Cuadernos Funsalud, Cidade do México, n. 18, p. 63-70, ago. 1996.

ESCOREL, Sarah. Reviravolta na Saúde: origem e articulação do movimento sanitário. Rio de Janeiro: Editora Fiocruz., 1998. 208 p.

EVANS, Peter. O Estado como Problema e Solução. São Paulo, Lua Nova, nº 28/29, p. 107156, 1993.

EZLN (Ejército Zapatista de Liberación Nacional). Declaración de la Selva Lacandona: ¡Hoy decimos basta! Diponível em : http://www.ezln.org/documentos/1994/199312xx.es.htm . Acesso em: 10 jun. 2003.

FADUL, W. Minha política nacional de saúde. Saúde em Debate (Wilson Fadul em entrevista concedida a revista Saúde em Debate) - CEBES, Rio de Janeiro, v. 7, n. 8, p. 67-76, 1978.

FALEIROS, Vicente de Paula. A Política Social do Estado Capitalista: as funções da previdência e da assistência social. São Paulo: Editora Cortez, 2000. 216 p.

FIORI, José Luis. Cenários Políticos Brasileiros para a década de 90. Série: Estudos em Saúde Coletiva - IMS/UERJ. Sobre os Tempos de Collor - Parte IV, Rio de Janeiro, 1994, 108 p.

FIORI, José Luís. Sobre os tempos de Collor - Parte I. Rio de Janeiro: Série Estudos em Saúde Coletiva n. 97, IMS/UERJ, 1994, 63 p. 
FIORI, José Luís; TAVARES, Maria da Conceição. O centésimo primeiro dia e depois. Série: Estudos em Saúde Coletiva - IMS/UERJ. Sobre os Tempos de Collor - Parte II, Rio de Janeiro, n. 102, p. 1-11, 1994.

FOLTZ, Anne-Marie. The Policy Process In JANOVSKY, Katja (Ed.) Health policy and system development: an agenda for research. Geneva: World Health Organization, 1996, p. 225-242.

FUNSALUD, FUNDACIÓN MEXICANA PARA LA SALUD. Health and the Economy: proposals for progress in the Mexican Health system Overview. México: Funsalud, 1995, 55p.

FUNSALUD, FUNDACIÓN MEXICANA PARA LA SALUD. La dimensión política en los procesos de reforma del sistema de salud, Documentos para el análisis y la convergencia 13. México: Funsalud, 1995, 103 p.

FUNSALUD, FUNDACIÓN MEXICANA PARA LA SALUD. La reforma de la Salud en México. Documentos para el análisis y la convergencia 18. México: FUNSALUD, 2001. 55 p.

FURTADO, Celso. O Mito do Desenvolvimento Econômico. São Paulo: Círculo do Livro, 1974. $122 \mathrm{p}$.

GENTILE DE MELLO, Carlos. A irracionalidade da privatização da medicina previdenciária. Saúde em Debate, n. 3, p. 8-15, 1977.

GERMER, C. M. O sistema de crédito internacional e a instabilidade financeira dos países da periferia capitalista. Economia e Sociedade, Campinas, (15):159-178, dez. 2000.

GERSCHMAN, Silvia A Democracia Inconclusa: um estudo da reforma sanitária brasileira. Rio de Janeiro, Editora FIOCRUZ, 1995. 203 p.

GIAMBIAGI, Fabio; ALÉM, Ana Cláudia. Finanças Públicas: teoria e prática no Brasil. Rio de Janeiro: Editora Campus, 1999, 380 p.

GIUGALE, Marcelo. Una agenda Integral de Desarrollo para la Nueva Era. Sístesis. GIUGALE, Marcelo; LAFOURCADE, Olivier; NGUYEN, Vinh H. (Ed.) Mexico: a comprehensive development for the new era. The World Bank, 2000, p. 23-47.

GOLVEIA, R. ; PALMA, J. J. SUS: na contramão do neoliberalismo e da exclusão social. Revista Estudos Avançados v. 13, n. 35, Dossiê saúde Pública, p. 139-146, 1999.

GÓMEZ-DANTÉS, Octavio. Evaluación de programa de salud para población no asegurada. Revista de Saúde Pública, São Paulo, v. 33, n. 4, p. 401-412, ago. 1999.

GÓMEZ-DANTÉS, Octavio et al. Abastecimiento de medicamentos en unidades de primer nivel de atención de la Secretaria de salud de México. Salud Pública de México, vol.43, n.3, p.224-232, mayo-junio, 2001.

GONZÁLEZ-BLOCK, M. Economía política de las relaciones centro-locales en las instituciones de salud en México. 1989. 310 f. Tesis (Para obtener el grado de doctor en ciencias sociales) - El Colegio de México, Ciudad de México, 1989.

GONZÁLEZ-BLOCK, Miguel, LEYVA, R \& ZAPATA, O. Health services decentralization in Mexico: formulation, implementation and results of policy. Health Policy and Planning, 4(4), p. 301-315, 1989. 
GOULART, Flavio A de Andrade. Experiências em Saúde da Família: cada caso um caso? 202. 387 f. Tese (Doutorado em Saúde Pública). Escola Nacional de saúde Pública, Fundação Oswaldo Cruz. Rio de Janeiro, 2002.

GOUREVITCH, Peter. A política do ajuste econômico: restrições e oportunidades. In: SOLA, Lourdes (Ed.) Estado, Mercado e Democracia: Política e Economia Comparadas. São Paulo: Paz e Terra, 1993, p. 422-444.

GOUVEIA, R.; PALMA, J. J. SUS: na contramão do neoliberalismo e da exclusão social. Revista Estudos Avançados - Dossiê Saúde Pública, São Paulo, v.13, n. 35, p. 139146, jan./abr. 1999.

GUIMARAES, César; VIANNA, Maria L. Teixeira Werneck. Planejamento e centralização decisória: o Conselho Monetário Nacional e o Conselho de Desenvolvimento Econômico. LIMA JR, Olavo Brasil, ABRANCHRES, Sérgio coords. As origens da crise: Estado autoritário e planejamento no Brasil. São Paulo: Vértice, 1987, p. 17-56.

GUTIÉRREZ ARRIOLA, Angelina. El IMSS: problemática y reestructuración. In: OSORIO, S \& RAMÍREZ LÓPEZ, B. Seguridad o Inseguridad Social: Los Riesgos de la Reforma. México, IIES/UNAM - Triana Editores, 1997, p. 99-128.

HABERMAS, Jurgen. Mudança estrutural da esfera pública: investigações quanto a uma categoria de sociedade burguesa. Rio de Janeiro: Tempo Brasileiro, 1984. 395 p.

HAGGARD, Stephan; KAUfMAn, Robert. O Estado no início e na consolidação da reforma econômica orientada para o mercado. In: SOLA, Lourdes (Ed.) Estado, Mercado e Democracia: Política e Economia Comparadas. São Paulo: Paz e Terra, 1993, p. 391421.

HALL, Peter \& TAYLOR, Rosemary. Political Science and the Three New Institutionalisms, MPIFG Discussion Paper 96/6, June, 1996, mimeo, 31 p.

HALL, Peter. The Organization of State-Society relations. In: HALL, Peter. Governing the Economics: The Politics of State Intervention in Britain and France. Oxford: Oxford University Press, 1986, p. 259-283.

HEIMANN, Luiza S. et al. Descentralização do Sistema único de saúde: trilhando a autonomia municipal. São Paulo: Sobravime, 2000, 131 p.

HIRSCH, Paul, MICHAELS, Stuart \& FRIEDMAN, Ray. Clean models vs. dirty hands: why economics is different from sociology In ZUKIN, Sharon \& DIMAGGIO, Paul eds. The Structure of the Capital: the social organization of the economy. Cambridge: Cambridge University Press, 1994, p. 39-55.

HOCHMAN, Gilberto. A Era do Saneamento. São Paulo: Hucitec, 261 p.

JATENE, A. Novo Modelo de saúde. Revista Estudos Avançados - Dossiê Saúde Pública, São Paulo, v.13, n. 35, p. 51-64, jan./abr. 1999.

JORGE SOBRINHO, Eduardo A . Políticas contemporâneas: fim do direito à Saúde? Saúde e Sociedade, São Paulo, v.11, n. 1, p. 5-14, jan./jul. 2002

KAUFMAN, Robert R. \& NELSON, Joan M. Introduction (Referente a capítulo de livro publicado em 2004, The politics of Health and Education in Latin America). Mimeo, 2003, 28 f. 
KAUFMAN, Robert R. \& TREJO, Guillermo. Regionalism, regime transformation, and PRONASOL: the politics of National Solidarity Programme in Four Mexican states. Journal of Latin American Studies, 29, p. 717-745, 1997.

KICKBUSCH, Llona. The development of international health policies - accountability intact? Social Science and Medicine 51, p. 979-989, 2000.

KINZO, Maria D’Alva Gil. O Quadro Partidário e a Constituinte. In LAMOUNIER, Bolívar org. De Geisel a Collor: o Balanço da Transição. São Paulo: Editora Sumaré/IDESP, 1990, p. 105-134.

KINZO, Maria D’Alva Gil. Oposição e Autoritarismo: gênese e trajetória do MDB (1966/1979). São Paulo: IDESP / Vértice, São Paulo, 1988.

KORNIS, G. E. \& ROCHA, P. M. A Saúde no Brasil dos 'Tucanos': Quo Vadis? Rio de Janeiro: Série: Estudos em Saúde Coletiva, n. 144, Instituto de Medicina SocialUERJ, 1996.

KRAUS, A . La salud de los mexicanos. La Jornada. Disponível em: http://www.jornada.unam.mx/2002/abr02/020417/019a2pol.php?origem=opinion.htm . Acesso em: 13/nov./2003.

KUCINSKY, B. Jornalismo e Saúde na era neoliberal. Saúde e Sociedade, São Paulo, v.11, n. 1, p. 95-104, jan/jul. 2002

KUGELMAS, Eduardo e SALLUM JÚNIOR, Brasílio. O Leviatã Acorrentado. In: SOLA, Lourdes (Ed.) Estado, Mercado e Democracia: Política e Economia Comparadas. São Paulo: Paz e Terra, 1993, p. 280-299.

KUGELMAS, Eduardo; SALLUM JÚNIOR, Brasílio e GRAEFF, Eduardo. Conflito Federativo e Transição Política. In São Paulo em Perspectiva, 3(3), p. 95-102, jul-set., 1989.

LAMOUNIER, Bolivar e SOUZA, Amaury. A Feitura da Nova Constituição: Um Reexame da Cultura Política Brasileira. In LAMOUNIER, Bolívar (Ed.). De Geisel a Collor: O Balanço da Transição. São Paulo: IDESP, 1990, p. 81-104.

LANE, Joan. A Social History of Medicine: Health, Healing and Disease in England, 17501950. London: Routledge, 2001. 256 p.

LAURELL, Asa Cristina. A Nova Face da Política Social Mexicana. Lua Nova, n. 32, p.1736, 1994.

LAURELL, Asa Cristina (Ed.) Estado e políticas sociais no neoliberalismo. São Paulo: Cortez. 244 p.

LAURELL, Asa Cristina. El Banco Mundial en la reforma de los servicios médicos Del IMSS. Salud Problema, v. 3, n. 4, p.57-62, jun. 1998.

LAURELL, Asa Cristina. La cuestión social mexicana y el viraje en la política social. In: VALENZULA, J. C. et al. (Ed.). México: ¿Fin de un Régimen? México: UAMIztapalapa, 1995, p. 117-134.

LAURELL, Asa Cristina. La globalización y las políticas de salud. Salud Problema, v. 3, n. 4, p.39-50, jun. 1998. 
LAZARSFELD, Paul F. \& OBERSCHALL, Anthony R. Max Weber and Empirical Social Research. American Sociological Review (30), p. 185-199, 1965.

LEAL, Gustavo F. Conflomerados hospitalarios privados. Tendencias recientes del Sistema Nacional de Salud. México: El Cotidiano - revista de la realidad mexicana actual, $\mathrm{n}$. 109, p. 88-96, 2001.

LEAL, Gustavo F. Agenda y Diseño de la Reforma Mexicana de la Salud y la Seguridad Social. Série Académicos CBS núm. 30. Universidad Autónoma Metropolitana Xochimilco, 2000. 138 p.

LEAL, Gustavo F. Evidencia para las políticas. México: Imagen Médica, 2003. 116 p.

LEAL, Gustavo F. Un paseo triste por cinco estaciones de una política abandonada. Salud y Seguridad Social en el tardo priísmo y el foxismo. El Cotidiano - revista de la realidad mexicana actual, n. 113. Universidad Autónoma Metropolitana, p.91-100, 2002.

LEE, Kelley \& GOODMAN, Hillary. Global Policy networks: the propagation of health care financing reform since the 1980s. In LEE, Kelley; BUSE, Kent; FUSTUKIAN, Suzanne eds. Health Policy in a Globalising World. Cambridge: Cambridge University Press, p. 97-119, 2002.

LENHARDT, Gero \& OFFE, Claus. Teoria do estado e política social: tentativas de explicação político-sociológica para as funções e os processos inovadores da política social. In: OFFE, Claus. Problemas estruturais do Estado capitalista. Rio de Janeiro: Tempo Brasileiro, 1984, p.10-52.

LEVCOVITZ, E ; LIMAS, L D; MACHADO, C. V.Política de saúde nos anos 90: relações intergovernamentais e o papel das normas Operacionais Básicas. Ciência e Saúde Coletiva, Rio de Janeiro., v. 6, n. 2, p. 269-291, 2001.

LEVCOVITZ, E, ; PEREIRA, T. R. C. SIH/SUS (Sistema AIH): Uma análise do sistemas público de remuneração de internações hospitalares no Brasil - 1983 - 1991. Série: Estudos em Saúde Coletiva - UERJ. Rio de Janeiro, n. 102, 83 f.

LEVCOVITZ, Eduardo et al. Produção de Conhecimento em Política, Planejamento e Gestão em Saúde (PP\&G) e Políticas de Saúde no Brasil (1974-2000). Série Técnica 2: Projeto de desenvolvimento e Serviços de Saúde, Organização Pan Americana de Saúde-Brasil/Ministério da Saúde-SAS, 2003. 75 p.

LEVCOVITZ, Eduardo. A capacidade operativa da rede assistencial do SUS. Serie Estudos em Saúde Coletiva N. 66. Rio de Janeiro: IMS/UERJ, 1993. 27 p.

LEVCOVITZ, Eduardo. Transição x consolidação: o dilema estratégico da construção do SUS. Um estudo sobre as reformas da política nacional de saúde - 1974/1996. 1997. Tese de Doutorado - Instituto de Medicina Social, Universidade Federal do Rio de Janeiro, Rio de janeiro, 1997.

LIMA Jr., Olavo Brasil. Instituições Políticas Democráticas: o Segredo da Legitimidade. Rio de Janeiro: Zahar Editores, 1997. 143 p.

LINZ, Juan. The future of an authoritarian Situation or the institutionalization of an authoritarian regime: The Case of Brazil. In STEPAN, Alfred, ed. Authoritarian Brazil. New Haven: Yale University Press, 1977, p. 233-254. 
LINZ, Juan; STEPAN, Alfred. A Transição e Consolidação da Democracia: A Experiência do Sul da Europa e da América do Sul. São Paulo: Paz e Terra, 1999. 321 p.

LITVACK, Jennie, AHMAD, Junaid and BIRD, Richard (Ed.). Rethinking Decentralization in Developing Countries. Washington: The World Bank, 1998. 40 p.

LOPEZ-ACUÑA, Daniel. La Salud Desigual en México. México: Siglo XXI, 1980. 247 p.

LOPÉZ-ARELLANO, O; Blanco-Gil, J. La polarización de la política de salud en México. Cadernos de Saúde Pública, Rio de Janeiro, 17(1), p. 43-54, jan-fev, 2001.

LUCCHESE, P. T.R. Descentralização do financiamento e gestão da assistência à saúde no Brasil: a implementação do Sistema Único de Saúde - retrospectiva 1990/1995. Planejamento e Políticas Públicas, Brasília, n. 14, p. 75-152, fev. 1997.

LUCCHESI, Geraldo. Burocracia e política de saúde: arena ou ator? In: TEIXEIRA, Sonia Fleury et. al. Reforma sanitária: em busca de uma teoria. 2. ed. Rio de Janeiro: Cortez Editora \& Abrasco, 1995 p. 157-180

LUSTIG, Nora. Mexico: The Remaking of an Economy. Washington: Brookings Institution, 1992. 185 p.

LUZ, M. T. Políticas de descentralização e cidadania: novas práticas em saúde no Brasil. Texto apresentado no Congresso da Asociación Latina para el Análisis de los Sistemas de Salud (CALASS 2001), p. 13, 2001. Disponível em http://www.alass.org/pt/calass.htm . Acesso em: 04 out. 2002.

LUZ, Madel T. As Instituições Médicas no Brasil: Instituições e Estratégia de Hegemonia. Rio de Janeiro, Graal, 1979, 201 p..

LUZ, Madel Terezinha. Medicina e Ordem Política Brasileira: políticas e instituições de saúde (1830-1930). Rio de Janeiro, Edições Graal, 1982. 218 p.

MACPAKE, Barbara. The Globalisation of health sector reform policies: is 'lessons drawing' part of the process. In LEE, Kelley; BUSE, Kent; FUSTUKIAN, Suzanne eds. Health Policy in a Globalising World. Cambridge: Cambridge University Press, 2002, p. 120139.

MAFFEZOLI, Lineu Carlos. Descentralização das Políticas Sociais: Limites e Possibilidades - Uma análise da Municipalização dos Serviços de Saúde no Município de Piracicaba. 1997. Tese (Doutorado em Economia) Instituto de Economia, UNICAMP, Campinas, 1997.

MALDONADO, Alberto H. Análisis de la implementación de la descentralización de los servicios de salud en el Estado de Colima 1996-2000. 2002. 108 f. (Maestria en Salud Pública) Instituto Nacional de Salud Pública do México, Cuernavaca, 2002.

MALLOY, James. Politics, Social Welfare Policy and the population problem in Latin America. International Journal of Health Services, n.12, p. 77-98. 1982.

MALLOY, James. Statecraft and Social Security Policy and Crisis: A Comparison of Latin America and the United States. In MESA-LAGO, C. org. The Crisis of Social Security and Health Care: Latin American Experiences and Lessons. Pittsburgh: University of Pittsburgh Press, 1985, p. 21-50. 
MALlOY, James. A Política de Previdência Social no Brasil. Rio de Janeiro: Graal, 1986. $167 \mathrm{p}$.

MALLOY, James. Statecraft, Social Policy and governance in Latin America. Kellogg Institute for International Studies Working Paper 151. 1991. 52 p.

MANTIN, P \& PULLEY, R. Medicine through the ages. London: Stanley Jones Publishers, 1997. p. 112.

MAYER-SERRA, Carlos Elizondo, NACIF HERNANDEZ, Benito. La lógica del cambio político en México. In MAYER-SERRA, Carlos Elizondo, NACIF HERNANDEZ, Benito comp. Lecturas sobre el cambio político en México. México: FCE, 2002, p. 740.

MÉDICI, André Cezar. Economia e financiamento do setor saúde no Brasil. São Paulo: Universidade de São Paulo, Faculdade de Saúde Pública, 1994. 216 p.

MENDES, A. N. ; SANTOS, S. B. de S. Financiamento descentralizado da saúde: a contribuição dos municípios paulista. Saúde e Sociedade, São Paulo, v.9, n. 1-2, p. 111-125, jan./dez. 2000.

MENDES, Eugênio V. “A crônica de uma morte anunciada” ou nascimento, paixão, morte e ressurreição do INAMPS. Brasília, mimeo, 32 f. 1993.

MENÉNDEZ, Eduardo L. El contexto técnico y económico-político de la crisis del modelo médico corporativo. In ALMADA BAY, Ignacio (coord.) Salud y Crisis en México: textos para un debate. México: Siglo Veintiuno Editores, 1990, p. 221-245.

MERHY, Emerson Elias. A Rede Básica como uma Construção de Saúde Publica e seus Dilemas. In MERHY, Emerson E \& ONOKO, Rosana. Agir em Saúde: um Desafio para o Público. São Paulo: Editora Hucitec, 2002, p. 197-228.

MESA-LAGO, C. Modelos de Seguridad Social en América Latina: Estudio Comparativo. Buenos Aires: Ediciones Siap-Planteos, 1977. 221 p.

MEYER, Lorenzo. Un tema añejo siempre actual: el centro y las regiones en la historia mexicana. In: TORRES, Blanca comp. Descentralización y Democracia en México. México: El Colegio de México, 1986, p. 23-34.

MIDDLEBROOK, Kevin J. Liberalização política num regime autoritário: o caso do México”. In: O’DONNELL, G.; SCHMITTER, P. \& WHITEHEAD, L. eds. Transições do Regime Autoritário: América Latina. São Paulo: Vértice, 1988, p.186-221.

MOGUEL, Julio. The Mexican Left and the Social Program of Salinismo. In: CORNELIUS , Wayne A.; CRAIG, Ann L.; FOX , Jonathan. Transforming State-Society Relations in Mexico: the National Solidarity strategy. San Diego: Center for U.S.-Mexican Studies - UCLA, 1994. cap. 9, p.168-176.

MOISES, Jose Álvaro. Dilemas da Consolidação Democrática no Brasil. In MOISÉS, José Alvaro \& ALBUQUERQUE, J A Guilhon. Dilemas da Consolidação Democrática. Rio de Janeiro: Paz e Terra, 1989, p. 119-177.

MORRIS, Stephen \& PASSE-SMITH, John What a difference a crisis makes: Nafta, Mexico and the United States. Latin American Perspectives, vol 28, n.3, p. 124-149, may, 2001. 
MUSGROVE, P. Public Spending in Health Care: How are different criteria related? Washington, World Bank, 1999.

NEGRI, Barjas. Introdução - a política de saúde no Brasil nos anos 90: avanços e limites. NEGRI, Barjas; VIANA, Ana Luiza d'Ávila Orgs. O Sistema Único de Saúde em dez anos de desafio: o passo a passo de uma reforma que alarga o desenvolvimento e estreita a desigualdade social. São Paulo: Sobravime, 2002, p. 15-44.

NELSON, Joan M. The Politics of Health Sector reforms: Cross-National Comparisons. (Referente a capitulo de livro publicado em 2004, The politics of Health and Education in Latin America) Mimeo, 2003, 58f.

NICK, Manning. Welfare, Ideology and Social Theory. In: BALDOCK et al. (eds.) Social Policy. Oxford: Oxford University Press, 1999, p.63-90.

NUNES, Américo. As Revoluções do México. São Paulo: Editora Perspectiva, $2^{\mathrm{a}}$ ed., 1999. $173 \mathrm{p}$.

NUNES, Everardo Duarte org. Juan César Garcia: pensamento social em saúde na América Latina. São Paulo: Cortez, 1989. 238 p.

O’TOOLE, Gavin. A New Nationalism for a New Era: The political ideology of Mexican. Bulletin of Latin American Research, volume 22, n. 3, p.269-290, July, 2003.

OCDE, Organización para la Cooperación y el Desarrollo Económicos (1998) Descentralización e Infraestructura Local en México: Una Nueva Política Pública para el Desarrollo. Paris, OCDE, 1998. 121 p.

OLIVEIRA, Fabricio A e BIASOTO JR, Geraldo. Descentralização das políticas sociais no Brasil. In ARRETCHE, Marta; RODRIGUEZ, Vicente orgs. Descentralização das Políticas Sociais no Brasil. São Paulo: Edições Fundap, 1999, p. 19-60.

OLIVEIRA, Fabrício Augusto. Autoritarismo e crise fiscal no Brasil (1964-1984). São Paulo: Hucitec, 1995. 196 p.

OLIVEIRA, J. A. A. A crise da previdência e seu impacto sobre a política de saúde. Saúde em Debate - CEBES, Rio de Janeiro, n. 13, p. 4-19, 1981.

OLVERA, Lucila S Análisis de la implementación de la descentralización de los servicios de salud en el estado de Baja California Sur (1996-2000). Tese (Mestrado em Saúde Pública) Instituto Nacional de Salud Pública, Cuernavaca, México: 2002.

ORGANIZACIÓN PANAMERICANA DE LA SALUD. México. In: ORGANIZACIÓN PANAMERICANA DE LA SALUD La Salud en las Américas - Edición de 1998 volumen II. Washington, D.C.; OPAS, 1998. p. 403-418.

ORNELAS, Carlos. La Descentralización de los Servicios de Educación y de Salud en México. In CEPAL. La Descentralización de la Educación y de la Salud. Chile: CEPAL, 1998, p. 187-207.

PAIM, Jairnilson Silva. A democratização da saúde e o SUDS: o caso da Bahia. Saúde em Debate - CEBES, Rio de Janeiro, p. 39-44, jun. 1988.

PAIM, Jairnilson Silva. Bases conceituais da reforma sanitária brasileira. In FLEURY, Sonia org. Saúde e democracia: a luta do CEBES. São Paulo: Lemos Editorial, 1997, p. 1124. 
PAIM, Jairnilson Silva. Medicina Preventiva e Social no Brasil: Modelos, Crises e Perspectivas. Saúde em Debate - CEBES, Rio de Janeiro, p. 57-59, jun., 1988.

PAULANI, Leda. Teoria da inflação inercial: um episódio singular na história da ciência econômica no Brasil. São Paulo: mimeo, 2003. 28 f.

PEREIRA, Carlos. A política pública como caixa de Pandoras: organização de interesses, processo decisório e efeitos perversos na reforma sanitária brasileira - 1985-1989. Dados - Revista de Ciências Sociais, Rio de Janeiro, 1996, v. 39, n. 3. Versão eletrônica, impressão formato html, p. 43. Disponível em: http://www.scielo.br/scielo.php?script=sci_arttext\&pid=S001152581996000300006\&lng=es\&nrm=iso . Acesso em: 3 abr. 2004.

PÉREZ CUEVAS, R \& REYES, H M. Análisis comparativo de un sistema de salud (Secretaría de Salud) y un programa de solidaridad social (IMSS-Solidaridad) para la atención a la salud de la populación abierta en areas rurales. México: IMSS Dirección de Prestaciones Médicas, Coordinación de investigación médica, 2003, 21 p.

PINHEIRO, Roseni \& MATTOS, Ruben Araújo orgs. Construção da Integralidade: cotidiano, saberes e práticas em saúde. Rio de Janeiro: IMS-UERJ / ABRASCO, 2003. 226 p.

PINHEIRO, Roseni \& MATTOS, Ruben Araújo orgs. Os Sentidos da Integralidade: na atenção e no cuidado à saúde. Rio de Janeiro: IMS-UERJ / ABRASCO, 2001. 178 p.

REICH, Michael R. Reshaping the State from above, from within, from below: implications for public health. Social Science and Medicine, 54, p. 1669-1675, 2002.

REZENDE, Fernando. O crescimento (descontrolado) da intervenção governamental na economia brasileira. In LIMA JR, Olavo Brasil e ABRANCHRES, Sérgio coords. As origens da crise: Estado autoritário e planejamento no Brasil. São Paulo: Vértice, 1987, p. 214-252.

RIKER, William. Federalism. In GRENSTEIN, Fred and POLSBY, Nelson (Ed.) Handbook of Political Science, Vol 5, New York: Harcourt Brace, 1975, p. 93-172.

RIZZOTTO, Maria Lucia Frizon. O Banco Mundial e as Políticas de saúde no Brasil nos anos 90: um projeto de desmonte do SUS. 2000. Tese (Doutorado em Medicina). Departamento de medicina preventiva e Social, Faculdade de Medicina, Universidade de Campinas, Campinas. 2000.

RODRIGUEZ NETO, E. Reunião da ABRASCO em Cachoeira, Bahia. Saúde em Debate CEBES, Rio de Janeiro, p. 33-38, abr. 1988.

RODRIGUEZ NETO, Eleutério. A via do parlamento. In FLEURY, Sonia org. Saúde e democracia: a luta do CEBES. São Paulo: Lemos Editorial, 1997, p. 63-92.

RODRIGUEZ NETO, Eleutério. Saúde: promessas e limites da Constituição. Rio de Janeiro: Editora FIOCRUZ, 2003. cap. 2, p. 33-52.

RODRÍGUEZ, Victoria. La descentralización en México: De la Reforma Municipal a Solidaridad y el Nuevo Federalismo. México: Fondo de Cultura Económica, 1999, $335 \mathrm{p}$. 
RONDINELLI, Dennis. What is decentralization? In LITVACK, Jennie and SEDDON, Jessica. Descentralization Briefing Notes. World Bank Institute, 1999, p. 2-5.

ROS, Jaime. Inflação e estabilização da economia mexicana. In IPEA, Plano Real e outras experiências internacionais de estabilização. Brasília: IOPEA/CEPAL, 1997, p. 75100.

ROSEN, George. Uma História da Saúde Pública. Rio de Janeiro: ABRASCO, 1994. 400 p.

ROSENAU, James. Governança, ordem e transformação na política mundial. In ROSENAU, James and CZEMPIEL, Ernst-Otto orgs. Governança sem governo: ordem e transformação na política mundial. Brasília: Editora UNB, 2000, p. 11-46.

ROUQUIÉ, Alain. Desmilitarización y la institucionalización de los sistemas políticos dominados por los militares em América Latina In O’DONNELL, Guilhermo e SCHMITTER, Philippe Transições de Regime Autoritário: América Latina, São Paulo, Vértice, 1988.

ROUSSEAU, Isabelle. México: ¿Una revolución silenciosa? Élites gubernamentales y proyecto de modernización 1970-1995. México, El Colégio de México, 2001. 536 p.

RUBIN, J. W. Decentering the regime: culture and regional politcs in Mexico. Latin America Research Review, Austin, v. 31, n. 3, p. 35-126, 1996

RUÍZ VELÁZQUEZ, Norma. La Política Social en México hacia el Fin de Siglo. México: Instituo Nacional de Administración Pública (INAP), 2000. 196 p.

RUIZ, Antonio Torres Descentralizacion en salud: algunas consideraciones para el caso de México. Documento de Trabajo CIDE n. 69. México: CIDE, 1997, 30p.

SADDI, Fabiana C. Estado e Federalismo no Governo Geisel: uma análise do federalismo na gênese da transição política brasileira. 1999. 153 f. Tese (Mestrado em Ciência Política). Departamento de Ciência Política. Faculdade de Filosofia, Letras e Ciências Humanas, Universidade de São Paulo. São Paulo, 1999. Disponível em: http://www.teses.usp.br/teses/disponiveis/8/8131/tde-17092002-121630/ . Acesso em: 10 jul 2004

SADDI, Fabiana C. Política e economia do federalismo no governo Geisel. Revista de Economia Política, São Paulo, volume 23, n. 2, p.28-46, abr., 2003.

SADDI, Fabiana da C. A dinâmica política da descentralização mexicana - o caso da política de saúde (de 1984 a 2000). In: XXVII Encontro Anual da ANPOCS 2003 (CD-ROM) 36 f., Caxambu, 2003.

SADDI, Fabiana da C. Political Transitions and the decentralisation of public health policies in Mexico and Brazil: arguments and hypothesis for a political comparison. SLAS Annual Conference 2003. Manchester, 2003, $25 \mathrm{f.}$.

SADDI, Fabiana C. Relaciones políticas y descentralizacion de la salud pública: comparando México y Brasil. X Congreso de Investigación en Salud Pública. Cuernavaca, 11 f., 2003. Disponível em: http://www.insp.mx/xcongreso/ponencias/TL007.ppt . Acesso em: 10 jul. 2004.

SAES. Quando novos personagens entraram em cena: experiências e lutas dos trabalhadores da grande São Paulo 1970-1980. Rio de Janeiro: Paz e Terra, 1988. 329 p. 
SALINAS DE GORTARI, Carlos. México: un paso difícil a la modernidad. México: Plaza \& Janés Editores, 2000. 1393 p.

SALLUM JR, Brasilio Labirintos: dos generais à Nova República. São Paulo: Editora Hucitec, 1996. 199 p.

SALLUM JR, Brasilio. Crise Econômica e mudança política: Brasil e México em perspectiva comparada. São Paulo: Departamento de Sociologia, Universidade de São Paulo, mimeo, 2000.

SALLUM JR, Brasilio. Federação, Autoritarismo e Democratização. Tempo Social, Revista de Sociologia da USP, vol 8, $\mathrm{n}^{\circ}$ 2, p. 27-52, 1996.

SALLUM JR, Brasilio. O Brasil sob cardoso. Tempo Social, Revista de Sociologia da USP, v. 8, n. 2, p. 23-48, 1999.

SALLUM JR, Brasilio. Transição Política e Crise de Estado. In SOLA, Lourdes e PAULANI, Leda M., orgs. Lições da Década de 80, São Paulo, Edusp, 1995, p. 137-170.

SALLUM JR., Brasilio. Metamorfoses do Estado brasileiro no final do século XX. Revista Brasileira de Ciências Sociais, São Paulo, v. 18, n. 132, p. 35-52, jun. 2003.

SÁNCHEZ-PÉREZ, C. D et al. Bienestar Social y Servicios de Salud en la Región Frailesca de Chiapas: el uso de servicios de atención prenatal. Salud Pública de México, v. 39, n. 6, nov/dez. 1997. Impressão da versão eletrônica, formato html, 13 p. Disponível em: http://www.insp.mx/salud/39/396-5.html . Acesso em 13 jun. 2003.

SANTOS, Wanderley G. dos. Cidadania e Justiça: a política social na ordem brasileira. Rio de Janeiro: Campus, 1979. 138 p.

SCHNEIDER, Ben Ross. The Desarrollista State in Brazil and Mexico. México, Documento de Trabajo CIDE, n. 88, División de Estudios Políticos, 1997, 29 p.

SCHWARTZMAN, Simon. Bases do Autoritarismo Brasileiro. Rio de Janeiro: Editora Campus, 1982. 163 p.

SEMPERE, Jaime \& SOBARZO, Horacio. Federalismo Fiscal en México. In SEMPERE \& SOBARZO comps. Federalismo Fiscal en México. México: El Colégio de México, 1998, p. 15-72.

SERRA, José. Ampliando o possível: a política de saúde no Brasil. São Paulo: Hucitec, 2000, 200 p.

SERRA, José. Entrevista à Revista: A Questão da Saúde no Brasil. Revista Estudos Avançados - Dossiê Saúde Pública, São Paulo, v.13, n. 35, p. 39-50, jan./abr. 1999.

SHAH, Anwar. Expenditure Assignment. In LITVACK, Jennie and SEDDON, Jessica. Descentralization Briefing Notes. World Bank Institute, 1999, p. 19-22.

SHAH, Anwar. Intergovernmental Transfers and Grants. In LITVACK, Jennie and SEDDON, Jéssica. Descentralization Briefing Notes. World Bank Institute, 1999, p. 27-31.

SILVA, Silvio Fernandes. Municipalização da Saúde e poder local: sujeitos, atores e políticas. São Paulo: Editora Hucitec, 2001. 292 p.

SILVA, Z. P.; BARRETO JÚNIOR, F.; SANT’ANA, M. C. A Política municipal de saúde em dados: a experiência da pesquisa municipal unificada PMU 1992, 1995 e 1997 da 
Fundação SEADE. Saúde e Sociedade, São Paulo, v.9, n. 1-2, p. 151-162, jan./dez. 2000.

SOARES, Luiz Eduardo. Vendendo saúde: O INPS e a seguridade Social no Brasil. Saúde em Debate, n. 1, p. 59-66, 1976.

SOARES, Luiz Eduardo. Vendendo saúde: o INPS e a seguridade social no Brasil (segunda e última parte). Saúde em Debate - CEBES, Rio de Janeiro, n. 2, p. 37-47, 1977.

SOBERÓN-ACEVEDO, G \& MARTÍNEZ-NARVÁEZ, G. La descentralización de los servicios de salud en México en la década de los ochenta. Salud Pública de México. 38, p. 371-378, 1996.

SOBERÓN-ACEVEDO, Guillermo. et. al. La Salud en México: Testimonios 1988 - Tomo I. México: SSA/Fondo de Cultura Económica, 1988. 381 p.

SOBERÓN-ACEVEDO, Guillermo. La salud: pasado, presente y futuro. México: El Colégio Nacional, 1999, 9 p.

SOEDERBERG, Suzanne. From Neoliberalism to Social Liberalism: situating the National Solidarity Program within Mexico's passive revolutions. Latin American Perspectives, vol 28, n.3, p. 104-123, May 2001.

SOLA, Lourdes. Choque Heterodoxo e Transição Democrática sem Ruptura: Uma Abordagem Transdisciplinar. In SOLA, Lourdes, org. O Estado da Transição: Política e Economia na Nova República, São Paulo: Vértice, 1988, p. 13-62.

SOLA, Lourdes. Estado, Transformação Econômica e Democratização no Brasil. In SOLA, Lourdes (Ed.). Estado, Mercado e Democracia: Política e Economia Comparadas. São Paulo: Paz e Terra, 1993, p. 235-279.

SOLA, Lourdes; KUGELMAS, Eduardo. Estabilidade Econômica e o Plano Real como construção política e democratização - statecraft, liberalização econômica. In SOLA, Lourdes; KUGELMAS, Eduardo; WHITEHEAD, Laurence (Eds.). Banco Central: autoridade política e democratização - um equilíbrio delicado. São Paulo: Editora FGV, 2002, p. 79-110.

SORIA, Victor M. Crecimiento Económico, Crisis Estructural y Evolución de la Pobreza en México. México: Universidad Autónoma Metropolitana Iztapalapa, 1999. 224 p.

SORIA, Victor. El fracaso de la política social. In: VALENZULA, J. C. et al. (Ed.). México: ¿Fin de un Régimen? México: UAM-Iztapalapa, 1995, p.135-144.

STEPAN, A. Toward a New Comparative Analysis of Democracy and Federalism, background paper, Conference on Democracy and Federalism, All Souls College, University of Oxford, Oxford: 1997.

STEPAN, Alfred. Os Militares: da Abertura à Nova república. Rio de Janeiro: Paz e Terra, 1984. $115 \mathrm{p}$.

STEWART, J. The Battle for Health: A Political History of the Socialist Medical Association (1930-51). London: Ashgate, 1999. 259 p.

STIGLiTZ, Joseph E. A Globalização e seus Malefícios: A Promessa não Cumprida de Benefícios Globais. São Paulo: Editora Futura, 2002. 327 p. 
TAMEZ, Silva, BODEK, Claudia e EIBENSCHUTZ, Catalina. Lo público y lo privado; lãs seguradoras y la atención méxcia en México. Cadernos de Saúde Pública, Rio de Janeiro, 11 (4), p. 579-578, 1995.

TAMEZ, Silvia; MOLINA, Nancy. The context and process of health care reform in Mexico. In FLEURY, Sonia; BELMARTINO, Susana; BARIS, Enis. Reshaping Health Care in Latin America: a comparative analysis of health care reform in Argentina, Brazil and Mexico. Ottawa: IDRC, 2000, 7 p. Disponível em: http://www.crdi.ca/books/focus/923/s2c06.htm, Acesso em: 20 abr. 2004.

TEIXEIRA, S. C. S. ; MONTEIRO, V. O. ; MIRANDA, V. A. Programa médico de família no município de Niterói. Revista Estudos Avançados - Dossiê Saúde Pública, São Paulo, v.13, n. 35, p. 147-158, jan./abr. 1999.

TOLEDO, Roberto Pompeu. O presidente segundo o sociólogo: entrevista de Fernando Henrique Cardoso a Roberto Pompeu de Toledo. São Paulo: Companhia das Letras, 1998. $366 \mathrm{p}$.

VERGARA, Carlos. El contexto de las reformas del sector de la salud. Revista Pan Americana de Salud Pública, 8(1/2), p. 7-14, 2000.

VIANNA, Maria Lucia Werneck. A americanização (perversa) da seguridade social no Brasil: estratégias de bem-estar e políticas públicas. Rio de Janeiro: Editora Revan. 270p.

WALT, Gil. Policy Analysis: an approach. In JANOVSKY, Katja ed. Health policy and system development: an agenda for research. Geneva: World Health Organization, 1996, 243-241 p.

WARD, Peter M. \& RODRÍGUEZ, Victoria E. New federalism, Intra-governmental relations and co-governance in Mexico. Journal of Latin American Studies, volume 31, number 3, p. 673-710, October 1999.

WARD, Peter M. Social Welfare Policy and Political Opening in Mexico. Journal of Latin American Studies, 25, p. 613-628, 1993.

WARD, Peter. Políticas de Bienestar Social en México (1970-1989). México: Nueva Imagen, 1989. $246 \mathrm{p}$.

WEBER, Max. (LASSMAN, P. and SPEIRS, R. Ed.) Weber Political Writings. Cambridge: Cambridge University Press, 1994. 390 p.

WEBER, Max. Économie et Societé: Les catégories de la sociologie, vol I, Paris: Agora, 1995. 409p.

WEBER, Max. Ensaios de Sociologia. ( Org. H.H. Gerth e C. Wrigh Mills). Rio de Janeiro: Editora Guanabara, $5^{\mathrm{a}}$ ed. 1979. 530 p.

WEBER, Max. Essais sur la théorie de la science. Paris: Plon, 1965. 478 p.

WEFFORT, Francisco. Qual Democracia?. São Paulo: Companhia das Letras, 1994. 165 p.

WEINGAST, B. The Economic Role of Political Institutions: market-preserving federalism and economic development. The Journal of Law, Economics \& Organization, 11(1), p. 1-31, 1995. 
WEYLAND, Kurt. Democracy without Equity. Pittsburgh: University of Pittsburgh Press, 1996. $312 \mathrm{p}$.

WHITEHEAD, Laurence. Idéias econômicas, doutrina e política na América Latina: os fundamentos movediços do liberalismo econômico na formação das políticas públicas. In SOLA, Lourdes; KUGELMAS, Eduardo; WHITEHEAD, Laurence (Eds.). Banco Central: autoridade política e democratização - um equilíbrio delicado. São Paulo: Editora FGV, 2002, p. 259-287.

WORLD BANK. Health, Nutrition, and Population (HNP) Sector Strategy. Washington: World Bank, 1997. 28 p.

WORLD BANK. Implementation Completion Report on a Loan in the amount of US\$ 310.0 million to NAFIN with the garantee of the United Mexican States for a Second Basic Health project. Washington: The World Bank, 2002. $43 \mathrm{f}$.

WORLD BANK. World Development Report 2002: Building institutions for markets. Disponível em: http://www.worldbank.org/wdr/2001/fulltext/fulltext2002.htm . Acesso em: 10 mar. 2003.

WORLD BANK. World Development Report 2004: Making Services Work for the Poor. Washington: The World Bank and Oxford University Press, 2003. Disponível em: http://www.econ.worldbank.org/wdr/wdr2004/text-18786 . Acesso em: 12 jan. 2004.

ZABLUDOVSKY KUPER, Gina. Patrimonialismo y dominación: poder y dominación en la sociología del Oriente de Max Weber. México: FCE, 1993. 194 p.

ZURITA, Beatriz. Innovaciones en la organización de los servicios. In: FUNDACIÓN MEXICANA PARA LA SALUD (FUNSALUD). Salud, Presente y Futuro: oportunidades e retos del binomio empresa/salud. Cuadernos FUNSALUD n 27. Ciudad de México: 1997, p.81-98. 